Florida International University FIU Digital Commons

3-26-2012

\title{
Small Farmer Market Knowledge and Specialty Coffee Commodity Chains in Western Highlands Guatemala
}

Courtney M. Dowdall

courtney.dowdall@fiu.edu

DOI: $10.25148 /$ etd.FI12050242

Follow this and additional works at: https://digitalcommons.fiu.edu/etd

\section{Recommended Citation}

Dowdall, Courtney M., "Small Farmer Market Knowledge and Specialty Coffee Commodity Chains in Western Highlands Guatemala" (2012). FIU Electronic Theses and Dissertations. 638.

https://digitalcommons.fiu.edu/etd/638 


\title{
FLORIDA INTERNATIONAL UNIVERSITY
}

\author{
Miami, Florida
}

\section{SMALL FARMER MARKET KNOWLEDGE AND SPECIALTY COFFEE COMMODITY CHAINS IN WESTERN HIGHLANDS GUATEMALA}

\author{
A dissertation submitted in partial fulfillment of \\ the requirements for the degree of \\ DOCTOR OF PHILOSOPHY \\ in \\ COMPARATIVE SOCIOLOGY \\ by \\ Courtney Marie Dowdall
}


To: Dean Kenneth G. Furton

College of Arts and Sciences

This dissertation, written by Courtney Marie Dowdall, and entitled Small Farmer Market Knowledge and Specialty Coffee Commodity Chains in Western Highlands Guatemala, having been approved in respect to style and intellectual content, is referred to you for judgment.

We have read this dissertation and recommend that it be approved.

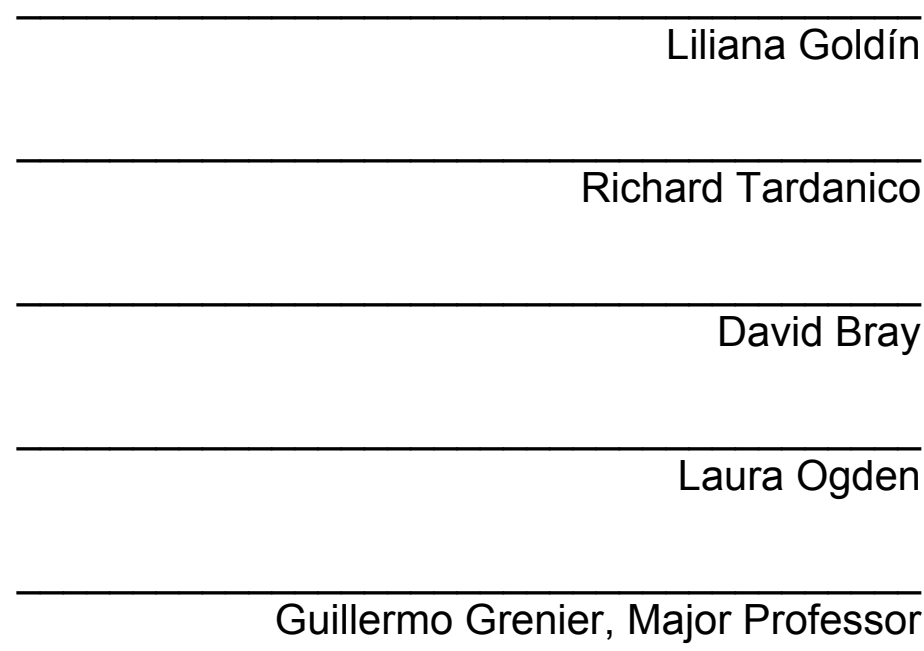

Date of Defense: March 26, 2012

The dissertation of Courtney Marie Dowdall is approved.

\begin{tabular}{r} 
Dean Kenneth G. Furton \\
College of Arts and Sciences \\
\hline Dean Lakshmi N. Reddi \\
University Graduate School
\end{tabular}

Florida International University, 2012 


\section{DEDICATION}

This dissertation is dedicated to my research partner, counselor, best friend, and husband, Ryan, whose encouragement, clarity, and brilliance has inspired me to take bigger risks and reap greater achievements than either of us ever thought possible. 


\section{ACKNOWLEDGMENTS}

I would like to thank the many friends, families, colleagues, and professors whose support and collaboration have made this work possible.

In the field, the residents of the communities in which I worked kindly opened the doors to their homes, invited me to sit at their dinner tables, and generously shared their thoughts and experiences with me. The teachers, my friends, at Celas Maya patiently helped me cultivate the indispensible conversational skills and cultural understanding that helped me conduct my research more graciously. My friends at Al Natur provided a sounding board for ideas and the feedback I needed to create a more revelatory survey. The roasters who made time for me in their busy schedules stressed the importance of the issues in this study and reminded me to focus on the practical applications of my research.

In the university, my long-time advisor, Dr. Liliana Goldín, has expressed unwavering confidence in my academic pursuits. She has been instrumental in focusing my attention and always pushed me to aim my efforts even a little higher. The advice of Dr. Guillermo Grenier, who has talked me through many of the key concepts of this study, has helped ground the theoretical arguments of this study in their practical implications and directed me to ask more meaningful research questions. Dr. Richard Tardanico has kindly entertained my endless statistical questions and resolved my concerns regarding research design and data collection. Owing to his experience with

coffee growing and certification, Dr. David Bray has offered invaluable insights 
to interpret the information I have collected and discuss the findings more accurately. Much of the theoretical lens through which the final version of this study was filtered is owed to Dr. Laura Ogden, who breathed new life into familiar research subjects.

Florida International University has generously supported me with financial assistance throughout all stages of my graduate career in the form of a Presidential Fellowship, Doctoral Evidence Acquisition Fellowship, and Dissertation Year Fellowship. The Doctoral Dissertation Research Improvement Grant from the National Science Foundation also provided funding essential to the completion of this study. The NSF Summer Institute for Research Design in Cultural Anthropology further contributed to the success of this study with crucial instruction in research design and effective reporting.

Finally, I would like to thank my mother, father, brothers, and parentsand sister-in-law for their love and patience throughout this trying process. They could never understand just how vital all the long-distance phone calls, letters of encouragement, and constant reassurances were to seeing this endeavor through to the end. 


\title{
ABSTRACT OF THE DISSERTATION \\ SMALL FARMER MARKET KNOWLEDGE AND SPECIALTY COFFEE \\ COMMODITY CHAINS IN WESTERN HIGHLANDS GUATEMALA
}

\author{
by
}

Courtney Marie Dowdall

Florida International University, 2012

Miami, Florida

\section{Professor Guillermo Grenier, Major Professor}

For producers motivated by their new status as self-employed, landowning, capitalist coffee growers, specialty coffee presents an opportunity to proactively change the way they participate in the international market. Now responsible for determining their own path, many producers have jumped at the chance to enhance the value of their product and participate in the new "fair trade" market. But recent trends in the international coffee price have led many producers to wonder why their efforts to produce a certified Fair Trade and organic product are not generating the price advantage they had anticipated. My study incorporates data collected in eighteen months of fieldwork, including more than 45 interviews with coffee producers and fair trade roasters, 90 surveys of coffee growers, and ongoing participant observation to understand how fair trade certification, as both a market system and development program, meets the expectations of the coffee growers. By comparing three coffee cooperatives that have engaged the Fair Trade system to disparate ends, the results of this investigation are three case studies that 
demonstrate how global processes of certification, commodity trade, market interaction, and development aid effect social and cultural change within communities. This study frames several lessons learned in terms of 1 . socioeconomic impacts of fair trade, 2. characteristics associated with positive development encounters, and 3. potential for commodity producers to capture value further along their global value chain. Commodity chain comparisons indicate the Fair Trade certified cooperative receives the highest per-pound price, though these findings are complicated by costs associate with certification and producers' perceptions of an "unjust" system. Fair tradesupported projects are demonstrated as more "successful" in the eyes of recipients, though their attention to detail can just as easily result in "failure". Finally, survey results reveal just how limited is the market knowledge of producers in each cooperative, though fair trade does, in fact, provide a rare opportunity for producers to learn about consumer demand for coffee quality. Though bittersweet, the fair trade experiences described here present a learning opportunity for a wide range of audiences, from the certified to the certifiers to the concerned public and conscientious consumer. 


\section{TABLE OF CONTENTS}

CHAPTER

PAGE

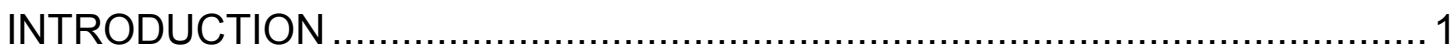

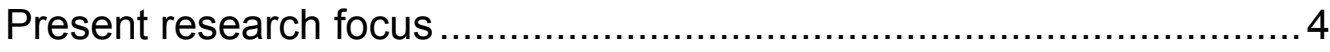

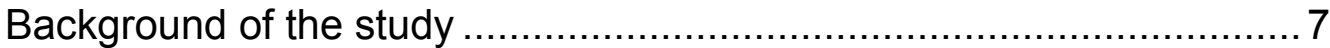

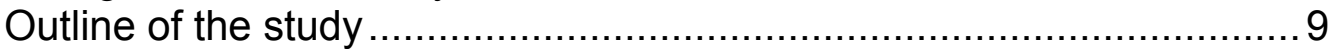

Purpose of the study ................................................................ 14

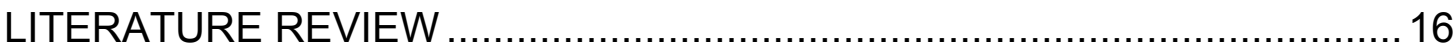

Reducing the "marketness" of coffee .......................................... 16

The first game changer: from 'fair trade' to Fair Trade ${ }^{\mathrm{TM}} \ldots \ldots \ldots .24$

The second game changer: fair trade goes mainstream ...........27

From re-embedding to dis-embedding …............................... 32

Rationalizing the decidedly irrational .............................................. 35

Rendering technical the fair trade practice ............................ 38

The unanticipated consequences of fair trade ........................4 41

One step forward, two steps backward .................................46

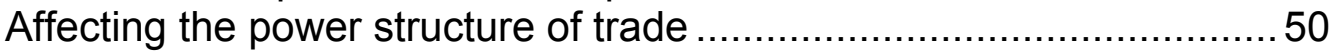

Lucrative potential of quality ................................................ 51

Bringing growers into the value-adding fold ...........................53

Fair trade as safety net or crutch......................................... 55

Theoretical potential versus experienced effects ............................... 58

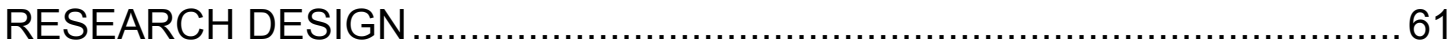

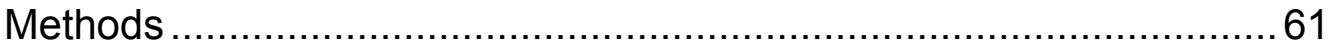

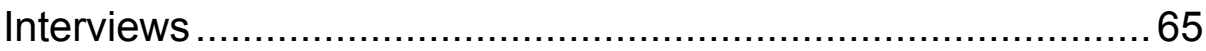

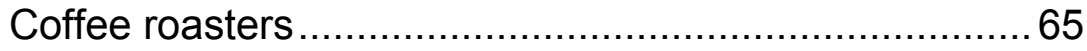

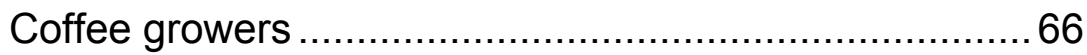

Other participants ……........................................... 69

Participant observation ........................................................ 71

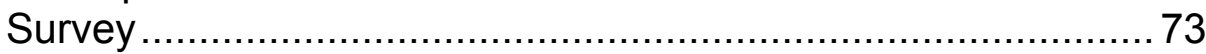

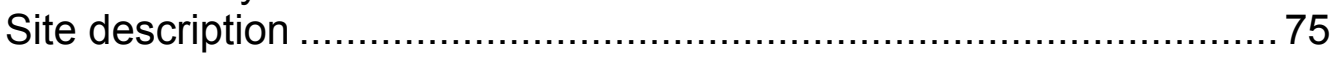

Bella Vista: the Fair Trade Certified community ......................78

Alta Gracia: the "relationship coffee" community ......................8 87

La Esperanza: the no-longer Fair Trade community ................. 95

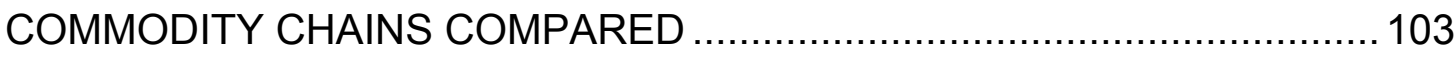

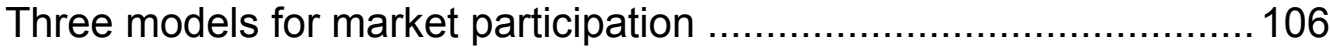

Fair Trade Certified cooperative ...................................... 108

Relationship coffee cooperative .......................................... 115

The no-longer Fair Trade cooperative .................................. 126

How much difference can it make? ............................................... 136 


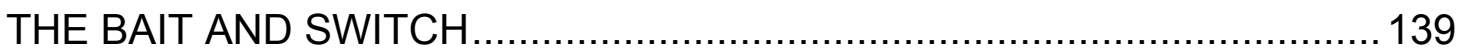

The Fair Trade experience, for better and worse ............................ 141

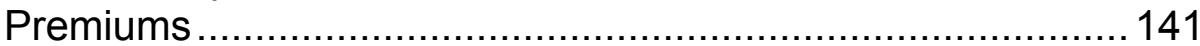

Economies of scale .................................................... 142

Price stability ............................................................... 145

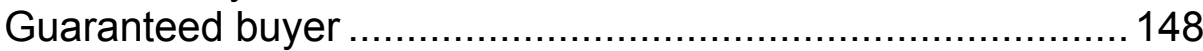

The payment schedule ................................................. 152

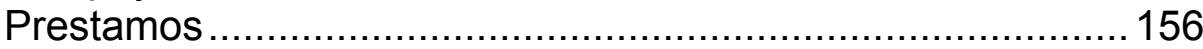

Hidden costs of certified production .................................... 158

Preserving natural resources ............................................. 165

Competitive market strategy or 'esclavitud'?................................. 172

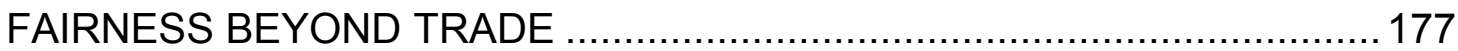

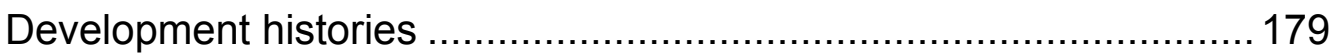

Foreign government agencies............................................. 183

Ecotourism and "development tours" .................................. 186

Local NGOs and governmental organizations....................... 190

Understanding the less-successful ventures................................... 191

Behind the more successful projects ...........................................200

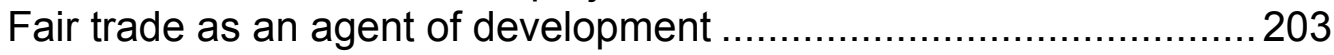

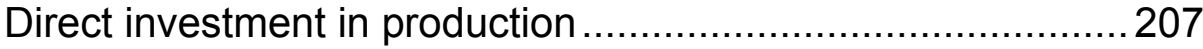

Investment in human capital ............................................216

Direct investment in the community ...................................220

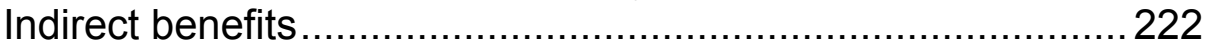

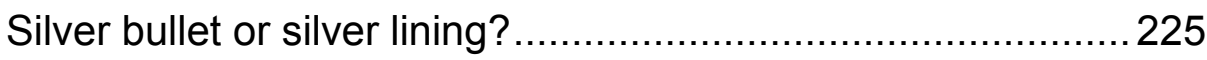

Running on the premio fumes ........................................22

The problem of too much embeddedness .............................228

The problem of too much support ........................................231

Calculating the value of Fair Trade ............................................. 234

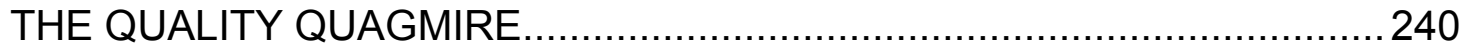

Dimensions of coffee quality ........................................................ 242

The production realm .................................................... 242

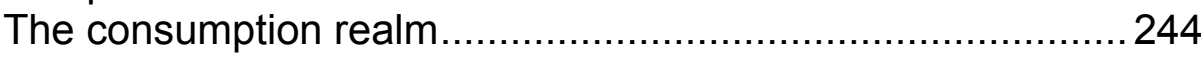

Quality concepts and community identity .................................249

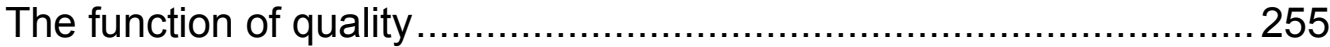

The immateriality of coffee quality ............................................256

To growers of this productive capacity .................................258

To the role of producers in the coffee commodity chain ..........260

To the ultimate goal of coffee growers .................................2262

A more profound understanding of quality .....................................265

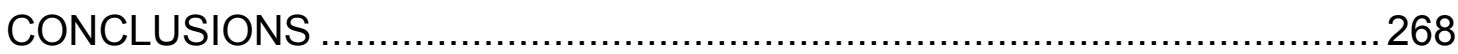

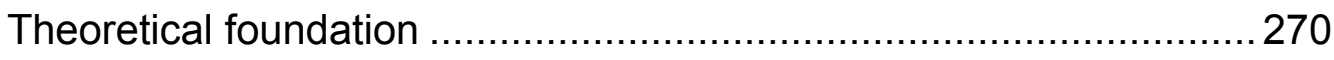

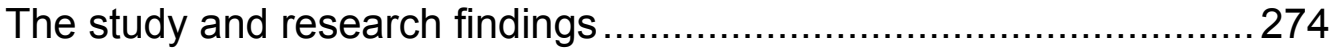

Recommendations for development programs ............................. 285 


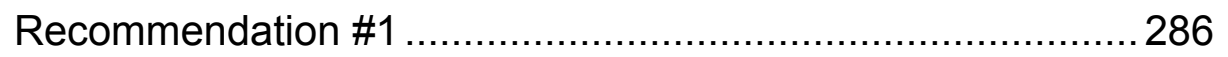

Recommendation \#2 ................................................ 287

Recommendation \#3 ................................................... 288

Recommendation $\# 4$................................................. 289

Recommendation $\# 5$...................................................... 290

Fruitful areas for continued research .................................. 291

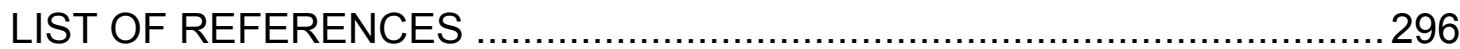

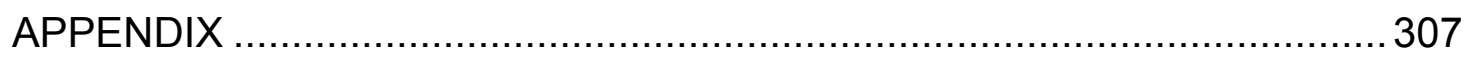

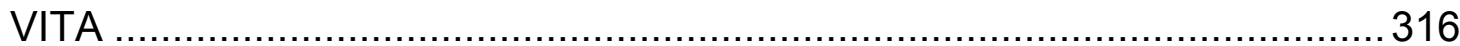




\section{LIST OF FIGURES}

FIGURE

PAGE

2.1 General structure of the global coffee-marketing chain .........................47

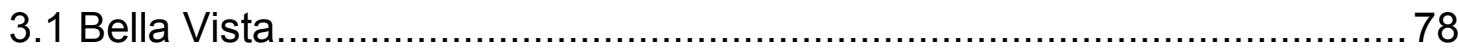

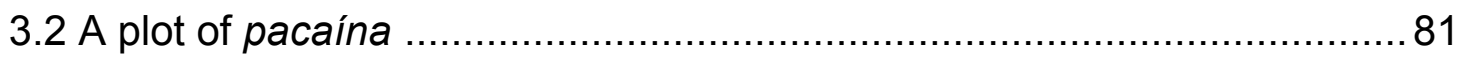

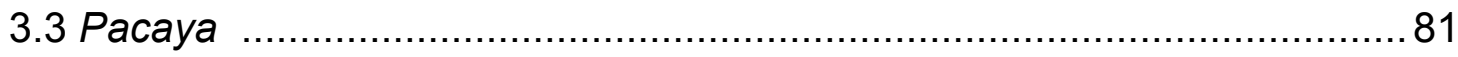

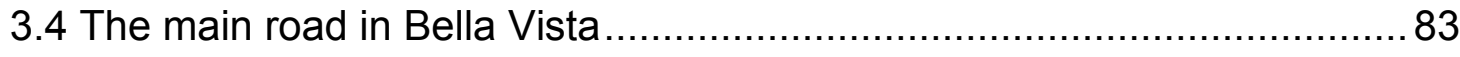

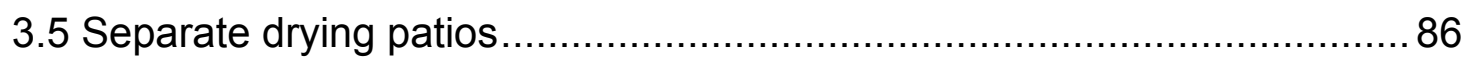

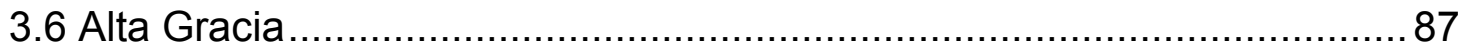

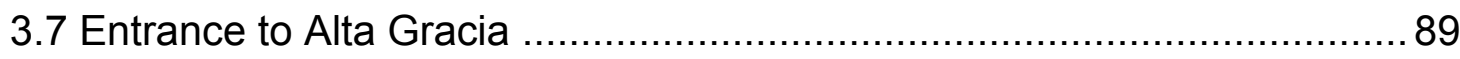

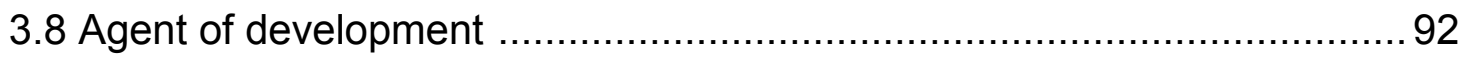

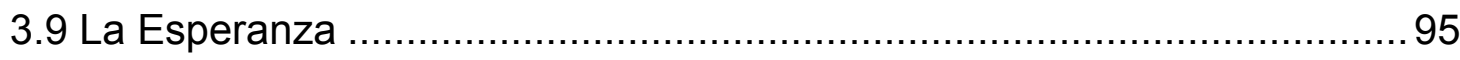

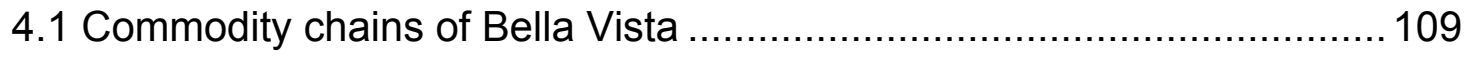

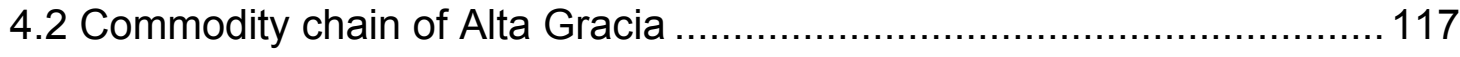

4.3 Processing costs reported by Roundtable Roasters ............................. 119

4.4 Production costs reported in Alta Gracia for 2009-2010 Harvest............ 125

4.5 Commodity chain of La Esperanza .................................................... 127

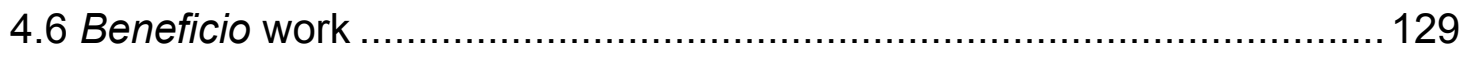

4.7 Flowchart illustrating the wet process .................................................. 131

4.8 Escogiendo (sorting) coffee in the Transcafé bodega ...........................132

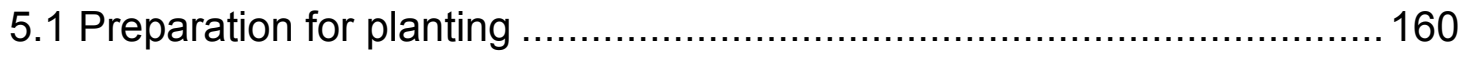

5.2a Selección (choosing cherries) in the fields........................................... 161

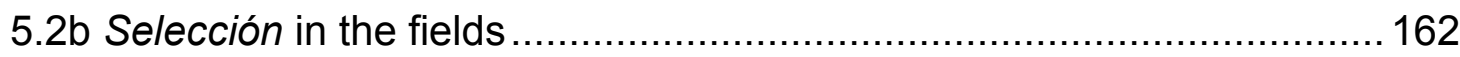




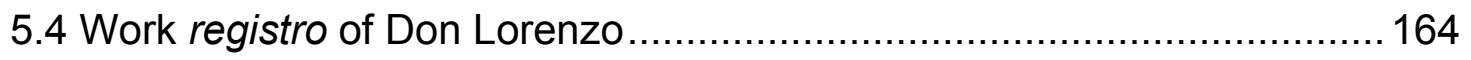

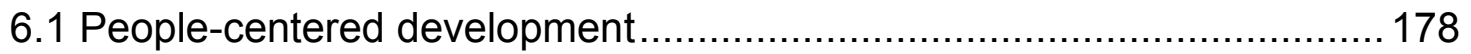

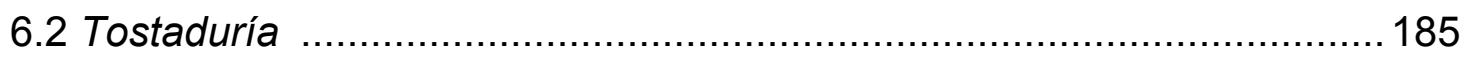

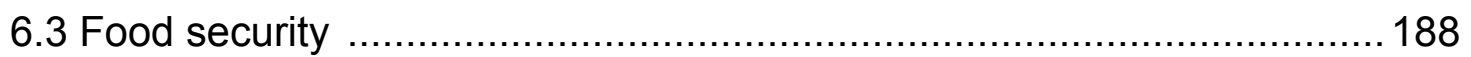

6.4 Paid staff of the vivero in La Esperanza ............................................212

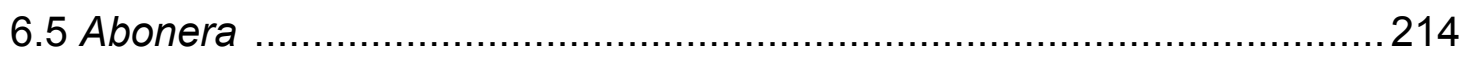

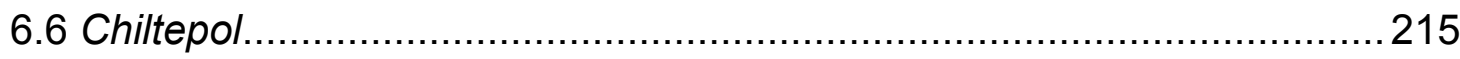

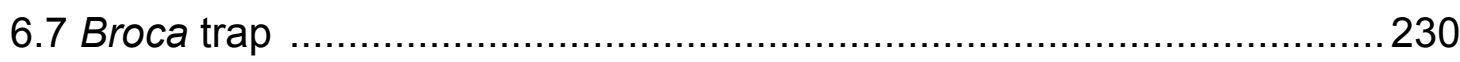

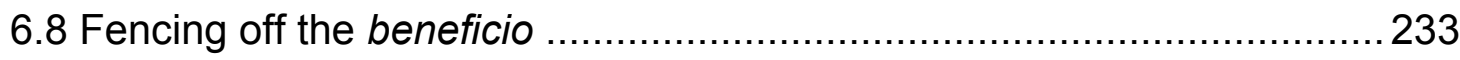

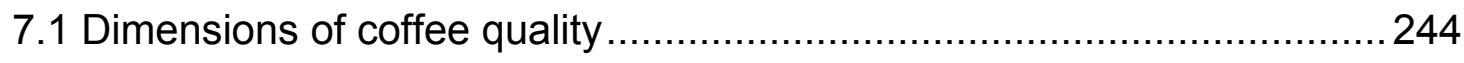

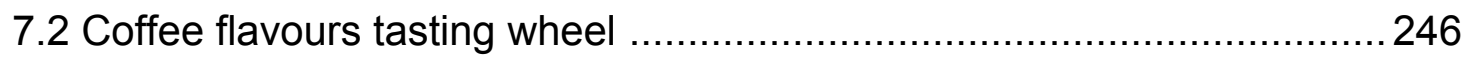

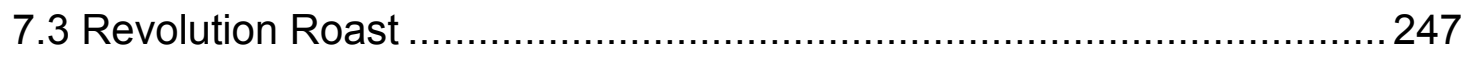

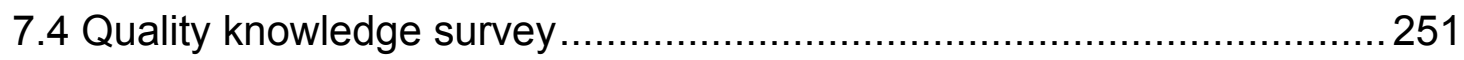




\section{LIST OF SPANISH TERMS USED IN THE DISSERTATION}

abajo - below

abonera - facility for producing organic fertilizer

abono - fertilizer

abono foliar - fertilizer sprayed directly on the leaves of a plant

acarreo - hauling

ácido - sour

afuera - outside

agradable - pleasant, nice

albergue - shelter

alcalde auxiliar - auxiliary council

alcanza - to be sufficient, to be enough, to reach

almácigo - nursery

altura - altitude

arroba - weight equal to 25 pounds

arroyado - digging holes

arrancar troncos - uprooting trunks

asamblea - assembly

azul - blue, describes beans covered by película

ballo - coffee cherry with some yellow coloration, slightly unripe coffee cherry

básico - equivalent to junior high or middle school years in the US, grades 7-9

beneficiar - to process coffee from cherry form to pergamino

beneficio - facility for processing coffee from cherry form to pergamino 
blando - mild

bodega - storage facility, warehouse

Bourbon - variety of Arabica coffee plant

broca - coffee borer beetle

broza - organic fertilizer; in its simplest form, compiled brush and deal leaves that have decayed into rich soil; also a more complex mix including sacate (weeds), levadura (yeast), ceniza (ash), melaza (molasses) or panela (brown sugar cake), gallinaza (chicken excrement), or estiercol (cow or pig manure)

bulto - bundle

cafetal - coffee plot

caficultor - coffee grower

cajetiado/cafetiado - occupied with assorted tasks that pertain to coffee growing

cal - lime powder

calidad - quality, value, worth, worthwhile

campesino - peasant, farmer

capacitación - training, education

caracol - snail, term describing a physical defect in the shape of a coffee bean

carera - equivalent to high school years in the US

casa grande - big house, the plantation owner's house

cascadita - little bits of shell, rind, covering

catación - tasting, a standardized process of evaluating the flavor and aroma of brewed coffee

catador - taster, one who is trained in catacion

catequista - catechist, person educated to share Christian principles 
Catuai - variety of Arabica coffee plant

Caturra - variety of Arabica coffee plant

Ceniza - ash

chileajo - a liquid comprised of chiles and garlic used as a form of organic pest control

Chiltepe - tiny and green, perhaps Guatemala's most famous and most widely used hot pepper

chiltepol - a liquid comprised of juice of chiltepe chiles

clasificación - classification, the process of sorting coffee into grades of quality

clima - climate

comercio justo - fair trade

concentrado - concentrate, animal feed pellets

consejo de administración - board of administration

control - control, observation of best practices to ensure coffee quality

control biológico - organic pest control

convencional - conventional, the typical field-to-market path, production using chemical inputs

coquetas rojas - red wigglers

coyote - coyote, intermediary between warehouse purchasers and coffee growers

cuadro directivo - management

cuchara - spoon

cuerda - $43.7 \mathrm{~m}^{2}$ (Wingens 2009)

- "The basic land measure in Chimbal is the cuerda of 25 varas square. A vara equals about 33 inches, making the cuerda in Chimbal about $70(68.75)$ feet on a side. There are roughly 9.22 cuerdas in an acre, 22.75 cuerdas in a hectare. Conversely, a cuerda equals about 0.11 acres, or 0.044 hectares. To add further to the confusion, 16 cuerdas 
make up a manzana (about 1.73 acres, or 0.70 hectares), and 64 manzanas comprise a caballería (about 111 acres, or 45 hectares). The census bureau in Guatemala uses the manzana as its basic unit of land measure." (Watanabe 1992)

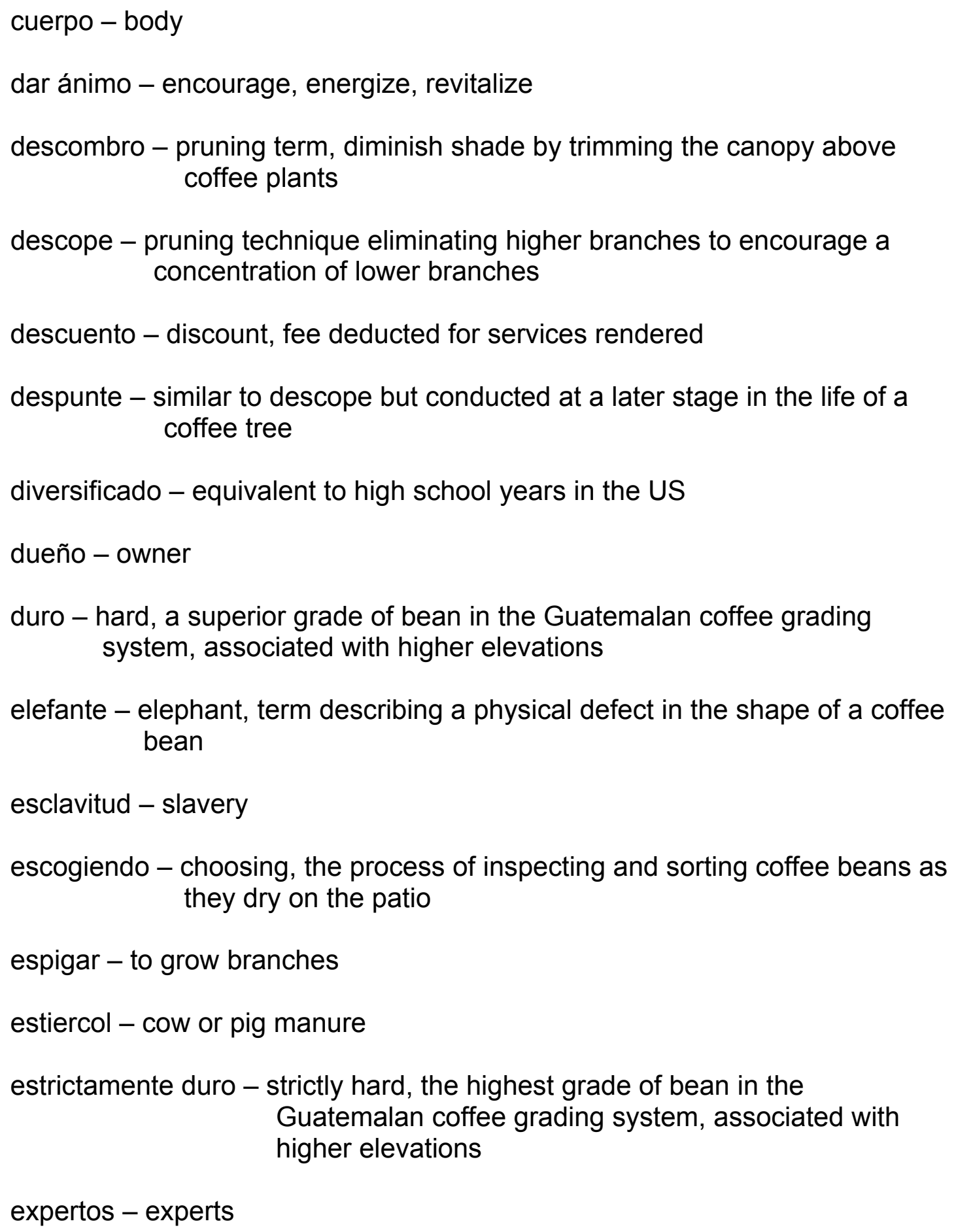


extra prime - extra prime, a lower grade of bean in the Guatemalan coffee grading system, associated with lower elevations

fermentación - fermentation

floreando - flowering, a crucial state in coffee production following rainfall, damage to flowers affects growth of coffee cherries

Fondo de Tierras/Fontierras - Land Fund, a government program offering loans for the purchase of land

frío - cold

gallinaza - chicken excrement

Gramoxone - toxic chemical herbicide banned in several European countries

grupo convencional - conventional group

grupo organico - organic group

hierba - herbs, grass, weeds, edible greens

hortalizas - garden vegetables

huele - to smell

humedad - humidity

injertos - grafted coffee plants

insumos - inputs, supplies, raw materials

Invernadero - greenhouse

junta directiva - board of directors

lavado - washed, refers to the process of fermenting and rinsing coffee beans to remove the miel

levadura - yeast

limpieza/limpia - cleaning, weeding, clearing land

lombricompost - vermicompost 
lombricultura - vermiculture

maduro - mature, coffee cherries at the peak of ripeness

manchado - spotted, speckled

machismo - "Exaggerated pride in masculinity, perceived as power, often coupled with a minimal sense of responsibility and disregard of consequences. In machismo there is supreme valuation of characteristics culturally associated with the masculine and a denigration of characteristics associated with the feminine. It has for centuries been a strong current in Latin American politics and society. Caudillos (military dictators), prominent in the history of Latin America, have typified machismo with their bold and authoritarian approach to government and their willingness to employ violence to achieve their ends." (Encyclopædia Britannica N.d.)

machista - male chauvinist, full of machismo

mata - plant, branch

media luna - half moon, technique for applying fertilizer to a coffee plant to encourage stronger roots

medioambiente - environment

melaza - molasses

mercados preferidos - preferred markets

miel - honey, sticky mucilage surrounding the coffee bean inside the fruit

ministra - minister, a member of the clergy

mochila - backpack

mozo - worker, laborer

nata - defective coffee beans, either ruined by broca or incompletely stripped of cascara (covering), usually reserved for domestic and local consumption

naturaleza - nature, wildlife

olor - odor, smell 
oriajo - a liquid comprised of urine and garlic used as a form of organic pest control

oro - gold, coffee in película form, processed for shipment with silver skin covering

pacaína - palm tree cultivated for ornamental leaves

pacaya - edible blossom of a variety of the date palm tree

Pache - variety of Arabica coffee plant

pastoral de la mujer - pastoral of women, organization of the Catholic church providing religious guidance to women

pastoral de la tierra - pastoral of the land, organization of the Catholic church providing guidance to farmers

pastoral del niño - pastoral of the children, organization of the Catholic church providing religious guidance to children

pastoral familiar - family pastoral, organization of the Catholic church providing religious guidance to families, particularly couples

panela - brown sugar cake

película - silver skin or chaff below parchment

peso - weight

pileta - basin

plaga - disease

poda - pruning

poda selectiva - selective pruning, eliminating selected branches to encourage denser production in remaining branches

podrido - rotten

primera - first, highest grade coffee produced on the finca

premio - premium, an additional payment added to the agreed-upon contract price 
prestamo - loan

prime - prime, the lowest grade of bean in the Guatemalan coffee grading system, associated with lower elevations

promotor - promoter, advises coffee growers of best practices in the field pulpa - pulp, fruit surrounding the coffee bean, a component of organic fertilizer

quimico - chemical

quintal - 100-pound sack in which coffee is usually transported, sold, and shipped

recepa - pruning technique eliminating unproductive branches to encourage growth of new branches

recojer troncos - collecting and removing trunks

registro - record

resiembra - replanting

retriya - machine for hulling coffee, removing the parchment, resulting in green coffee

riego - irrigating, also distributing, applying, spraying

rojo - red, coffee cherries at the peak of ripeness

¿Saber? - Who knows?

sabor - flavor, taste

sacate - grasses, weeds, general green overgrowth

sano - healthy, undamaged, intact, entire

seca - dry

secadora - dryer, machine in the beneficio used for drying coffee beans segunda - second, middle grade coffee produced on the finca 
selección - selection, the process of choosing coffee cherries to pick off the plant

selladora/sellador - sealer, machine used for sealing bags shut

semiduro - somewhat hard, a moderate grade of bean in the Guatemalan coffee grading system, associated with moderate elevations

semilla - seed

siembra - planting

sumos - juices

socio - group member, partner

tamaño - size

tapisca - harvest, used to describe coffee and corn

teóricamente - theoretically

techo - ceiling, cap, maximum, limit

terreno - land, terrain

textura - texture

Thiodan - toxic and highly controversial chemical insecticide banned from manufacture or use in many countries

tostaduría - roasting facility

trabajado - worked, made, crafted, tended

traje - dress, suit, outfit, specifically traditional attire

Typica - variety of Arabica coffee plant

Vale la pena. - It's worth it.

variedad - variety

veneno - poison

verde - green, unripe coffee cherries 
vivero - nursery 
LIST OF ABBREVIATIONS AND ACRONYMS:

NYCE New York Commodities Exchange

ORPA Organización Revolucionario del Pueblo en Armas (Revolutionary Organization of the People in Arms)

ATO alternative trade organization

MNC multinational corporation

GVC global value chain

URNG Unidad Revolucionaria Nacional Guatemalteca (Guatemalan National Revolutionary Unity)

OPTCO Organic Products Trading Company

FLO Fairtrade Labelling Organizations International

CRS Catholic Relief Services

FUNDAP Fundación para el Desarrollo (Foundation for Development) 


\section{Chapter I: Introduction}

No more than twenty years ago, to imagine a coffee plantation in Guatemala was to envision landless peasants working under the direction of a finca owner. A "lucky" few permanent workers rented a shack and resided on the plantation property, while the majority migrated seasonally from highlands to shore in search of work. Women rose before dawn to pack lunch for their husbands and spent the remainder of the day bound to the home, tending to endless household cooking, cleaning, and childrearing. Men spent all day hunched over digging holes and cutting weeds, struggling to maintain solid footing on the steep hillsides. In the peak of harvest season, women and children sneaked around the coffee fields, furiously stripping branches of coffee berries and adding their contributions to the baskets of the men so as not to get shorted by a lesser pay rate. Work availability was unpredictable and unstable. A glut of coffee from Brazil or Colombia meant a bad year for international coffee prices, which could result in tightening of finca owners' belts. Less investment in production and harvesting translated into fewer work opportunities, greater competition, and lower per-day or per-basket wages.

In the last twenty years, however, the image of a typical coffee farm in Guatemala is no longer so easily categorized. Cooperatives of small family farms have risen in the place of finca owners who folded with the last major coffee crisis. Now coffee growers, no longer inserted into production only at the final stages of harvest, some are dictating their own cultivation practices from seed to sack. Residency is less tenuous as communities of coffee 
growers experience the security and responsibility of landownership for the first time. Women may be smallholders themselves, picking up the reins as head of household from a deceased husband. Boys and girls alike receive an education, while their parents grapple with the unfamiliar issue of how to support their children in whatever career they will pursue. While little has changed in the back-breaking nature of coffee cultivation, the role that coffee growers in Guatemala occupy in the international process of bringing beans to the brewed cup has changed dramatically with the tumultuous makeover of the global market for coffee.

This revolutionary process of company-store coffee farm turned producer-owned community is not unique to Guatemala. In fact, as the coffee crisis of the 1990s led owners of small and medium sized coffee farms to abandon their holdings, governments throughout Central America responded with loan programs to encourage the resettlement of so many empty fincas. In an effort to revive their coffee industries, government agencies established training programs to capacitate new farmers in best cultivation practices. Viewed as war-torn, underdeveloped, and deserving of aid, Central American countries were the focus of vast international assistance. Received at a time of neoliberal restructuring of social safety nets, residents have been overwhelmingly receptive to development support. As a result, the agricultural workers of Guatemala, in general, and especially in the coffee industry, have been the subjects of a flood of international development programs. 
Frustrated at their helplessness in the wake of wildly vacillating international prices, smallholders throughout the world are seeking alternative avenues of market entry. For producers motivated by their new status as selfemployed, landowning coffee growers, specialty coffee presents an opportunity to proactively change the way they participate in the international market. Now responsible for determining their own path, many producers have jumped at the chance to enhance the value of their product and participate in the new "fair trade" market, which is intended to play by different rules.

Fair trade is designed to serve the interests of both producers and consumers. It acts as a chaperone, ushering producer goods into the international market under protective terms of trade, as well as a witness, testifying as to the social, environmental, and economic responsibility of production. Vital to both roles is the embedded position of fair trade roasters within the producer communities they aim to serve. Murdoch, Marsden, and Banks (2000) define a "re-embedded" good as one whose value is rooted in local and regional contexts. By virtue of their familiarity with the context of production - the location, terrain, lives of producers, value of environmental preservation, community identity - members of the fair trade movement are well-positioned to both effectively engage producers and market fairly trade, vouching personally for their authenticity.

But recent trends in the international coffee price have led many producers in the Fair Trade network to question the benefits of this market system. For those who have pursued Fair Trade Labelling Organization (FLO) 
certification, a trademarked form of fair trade, the efforts they were told would add value to their coffee as a certified Fair Trade and organic product do not seem to be generating the price advantage they had anticipated. Though they have upheld their commitment to socially responsible production, they have watched their price advantage steadily dwindle since 2007. Conventional prices continue to rise, revealing a critical flaw in the market-based Fair Trade system of development: coffee growers and the chaperones of the fair trade market have differentially problematized the role of producers in the international market. While growers have sought means of becoming more competitive players in the global market, coffee retailers have worked to buffer producers from the impact of wildly fluctuating market prices.

\section{PRESENT RESEARCH FOCUS}

My study examines the dissonance between producer objectives and experiences of participation in the fair trade network. Many producers saw themselves as taking proactive measures to compete more effectively in the international market, though over time the effect is quite the opposite. Viewed first as taking control of their role in the market, changing cultivation practices to create a more valuable product, they now feel duped into a greater burden of labor with little economic advantage. Initially treated as a lifebuoy to float producers through sinking global prices, the stable fair trade price now appears more as shackles, locking producers into what is now an "unfair" price. 
At the heart of this disappointment lies the disconnect between FLO, as a development organization, rendering of the problem to be solved and the problem as framed by development recipients. Though admirably ambitious, researchers such as Ferguson (1994), Scott (1998), and Li (2007), have shown how development schemes that attempt to improve the lives of their recipients by covering them under a broadly cast net of aid often result in disappointment. The remnants of these unsuccessful development projects abandoned pig sties, recycling plants, chicken coops, clinics - can be found throughout the developing world. Oversimplification of needs and solutions tends to eliminate from consideration the diverse backgrounds, foundations of resources and skills, and ultimate objectives that impact the development outcome.

Members of the fair trade network stand in a unique position to incorporate their intimate knowledge of their growers' lives and goals into a more effective and satisfying development experience. The embeddedness of fair trade members could create an advantage in designing more appropriate development strategies, wherein recipients and agents of development collaborate toward a shared vision of community growth. Projects could be tailored to build on existing strengths and resources and geared to reach unique goals. However, in what many view as an unfortunate shift of direction, changes in marketing strategy have necessitated a disembedding of Fair Trade services and products from the site of production, thereby 
compromising the crucial advantage once held over typical top-down development schemes.

This study demonstrates the importance of communication between development agents and recipients in designing successful projects. By comparing three coffee cooperatives at differing stages of Fair Trade certification, this study evaluates the benefits as well as the challenges of development programs tailored to the needs of a specific community. It examines both the areas of development most anticipated by producers altering the commodity chain and increasing profits from coffee - as well as (welcome and unwelcome) unexpected outcomes.

Much as fair trade holds unique advantages for successful development, the same catch-22 of embeddedness can be found in its unique approach to market interaction. The comparison of cooperatives now engaged in three different forms of trade - certified Fair Trade, "relationship coffee", and post-Fair Trade conventional - examines the difficulties of balancing community embeddedness with mainstream market demands. The social context attached to a good imbues it with specific attributes, rendering it unique, rare, and valuable. At the same time, maintaining these very qualities requires time, personal attention, and individually-catered terms of trade, rendering embeddedness a valuable as well as cumbersome trait to maintain. As the trademark of the fair trade movement, maintaining embeddedness is a challenge that lies in the future of the movement. 
Finally, economists' and social scientists' have criticized fair trade as at least meddlesome (Berndt 2007, Pirotte et al. 2006, Parrish et al. 2005) and at worst damaging (Booth and Whetstone 2007). In response, this study evaluates the free-trade-versus-fair-trade argument that increased market knowledge begets improved quality and, ultimately, higher profits. Fair trade has been a target of many economists' ire due to its practice of subsidizing prices and paying stable rates. While the knowledge $=$ quality $=$ profits equation may indeed be applicable to coffee growers of a particular scale, size, and capacity, this study demonstrates the difference between growers engaged in fair trade and the growers who may benefit from "free" trade. Furthermore, this study identifies some structural barriers that limit indefinitely the capacity for many coffee growers to transform quality knowledge into a greater portion of retail value. I demonstrate that the fair trade model can be a beneficial compromise between learning to maneuver in the international market and blindly selling through intermediaries.

\section{BACKGROUND OF THE STUDY}

The initial concept for this study was simple enough - to profile a Fair Trade certified cooperative and explore the on-the-ground impacts of Fair Trade certification. Guatemala made a fine location for study, given the importance of coffee production in the country's export economy and the proliferation of agricultural cooperatives following the 1996 Peace Accords. 
The exploratory phase of this project was initiated in 2007, when I began inquiring in Quetzaltenango, the second largest city in Guatemala, about potential research sites. The qualifications were basic - a Fair Trade coffee growing cooperative where residents were willing to share their experiences. The response, however, was surprising. Nearly all my friends and contacts in the city had a relative involved in coffee production. Everyone knew of a fair trade cooperative. All were eager to help me make connections with cooperatives, NGOs, coffee organizations, fair trade shops, volunteer organizations, and anyone else who might have some insight to share.

As a result, I visited three fair trade coffee growing cooperatives in the first round of fieldwork. In 2008, I revisited these cooperatives and an additional new site. Over the course of these trips, I learned the breadth of the definition of comercio justo (fair trade) among Guatemalans, which had little to do with certification. Rather, fair trade implied a collective of small-scale family farms, usually struggling with rights to land ownership, independently searching for a foreign buyer, trying to avoid selling through coyotes (middlemen).

While the cooperatives held these fundamental characteristics in common, they diverged in many others. Their experiences in coffee growing, collective living, business negotiations, and communication with foreigners varied greatly. Their goals for the future ranged from returning a finca to its former fully-productive glory, to providing their children with an alternative, to agricultural life to building their own Campesino University for neighborhood 
workshops. While it was feasible to talk broadly of a Guatemalan cooperative and assume some basic characteristics, it was equally possible to enumerate the crucial ways in which they differed, ways that would necessarily affect the outcome of a development initiative such as Fair Trade certification.

The disparity between the concept of Fair Trade which I bore in mind as I started my project and the ideas of fair trade I encountered in the field led me to me alter the focus of the study. It became clear that Fair Trade, practiced as a monolithic approach to development, would certainly lead to disappointment for some communities, neglect opportunities to build on existing strengths in others, and ultimately fall short of many of its own objectives.

Rather than profile a single cooperative, a more informative study would compare varied systems of practicing fair trade, illustrating the ways they suit the particular resources and goals of different communities. In this way, the study has become more revelatory, examining several permutations of the factors that shape the outcome of a development project. The final approach to this study maintains the original goal of understanding the experience of Fair Trade certification, but the inclusion of three very similar yet very different cooperatives in a comparative research design provides a more nuanced picture of how Fair Trade works.

\section{OUTLINE OF THE STUDY}

To understand how Fair Trade certification, as both a market system and development program, meets the expectations of the coffee growers it is 
intended to support, this study compares three coffee cooperatives that have engaged the Fair Trade system with differing results. In investigating Fair Trade as a development scheme, my study asks what makes the fair trade approach unique and how the efficacy of program design varies with the level of collaboration between the organization and the community. Treated as a market-based development system, this study asks how successful is fair trade in providing an economic advantage for producers, and if any additional advantages result from participating in this market system. Additionally, critics (Berndt 2007, Booth and Whetstone 2007, Pirotte et al. 2006, Parrish et al. 2005) claim that the fair trade market system does a disservice by obscuring a crucial quality/value relationship. To evaluate this assertion, the present study first asks whether fair trade does, in fact, provide producers with the information to associate higher quality with higher prices. My study investigates whether producers in the fair trade system are aware of the quality attributes that add value to coffee. Finally, the present study evaluates the opportunities for producers to turn knowledge of coffee quality into higher profits.

The results of this investigation are three case studies that demonstrate how global processes of certification, commodity trade, market interaction, and development aid effect social and cultural change within communities. The comparative case study design of this research make the following contributions to both theory and development practice: 
- Demonstrates the complexity of economic goals held by new participants in the global economy

- Illustrates the strengths and weaknesses of fair trade in achieving producers' social and economic development goals for development

- Clarifies the relationship between context-specific characteristics and the outcomes of development projects

- Identifies characteristics of development program design associated with more successful outcomes

- Reveals the nuanced impacts of shortening the commodity chain for producers of a good such as coffee

- Increases understanding of the capacity of fair trade to enhance producers' market knowledge

By examining the impact of global market processes on the lives and experiences of producers, the study contributes to middle range anthropological and sociological theories of development, economics, production, and trade.

Chapter 2 critically engages the history of the fair trade movement as it has evolved from an informal trade network to a multi-million-dollar certification system, as well as the resultant changes in philosophy and goals and varied reactions among different members of the movement. In doing so, this chapter expounds upon the concepts of rationalization, "marketness", commodity- and value-chains, and embeddedness, illustrating the diversity in practices of fair 
trade and the possible range of engagement between producers and consumers.

In Chapter 3, I describe the mixed-methods approach of this study, incorporating participant observation, interviews, and surveys with participants at both the production and retail end of the commodity chain for coffee. The combination of methods - collecting both qualitative and quantitative data from multiple perspectives in the coffee marketing process - provides both emic and etic insight into the impacts of Fair Trade certification. This chapter also provides site descriptions for the three communities in which the study is based, describing the historical, demographic, and cultural context that is frequently overlooked by large-scale top-down development programs.

Chapters 4 and 5 describe the economic impacts of fair trade compared with the conventional market system for coffee. In Chapter 4, I construct the commodity chain for each community, explaining the activities conducted by each firm in the process, and revealing the differences in prices returned to producers associated with each system of market participation. In contrast with expectations, a comparison of commodity chains reveals the Fair Trade system to have a longer commodity chain than the community selling "relationship coffee." Despite the longer chain of the Fair Trade certified system, it still returns to producers the highest per-pound price. Chapter 5 , then, examines the broader economic impacts associated with fair trade. Chapter 5 illustrates the unanticipated consequences of production and sales through a fair trade system, demonstrating the ways in which community-level 
variation produces disparate results. What may be viewed as market advantages in one community are received in another as drawbacks to the fair trade system.

Chapter 6 presents the indirect benefits of fair trade as identified by producers, which lie largely in the realm of social development. This chapter first describes the development histories of these communities, explaining how and why so many well-intended development projects have failed to bring about the improvements they had proposed. Next, the development efforts associated with participation in fair trade are shown to meet with greater success, largely due to the unique approach of recipient-generated proposals and long-term support made possible by embeddedness within a community.

In Chapter $7 \mathrm{I}$ discuss the results of the market knowledge evaluation portion of the study. In this chapter I explain the divergent concepts of quality held by producers and purchasers of coffee, as well as the varied levels of knowledge held by specific community members. In evaluating the potential for coffee producers to use such knowledge to an economic advantage, I discuss the structural barriers that prevent farmers from participating in valueadding stages of production as well as the unfair burden of risk indefinitely borne by the production end of the value-chain. Instead, the fair trade system is seen to provide a happy medium of education about coffee quality within the safe confines of secure terms of trade.

Finally, Chapter 8 provides a summary of the research findings and their contributions to the theories outlined above. In sum, fair trade in its 
various forms is demonstrated to provide significant benefits to the producers it aims to help, though these benefits often lie outside the realms where positive change was anticipated. Overall, though the economic benefits are minimal, perhaps outweighed by the greater cost of production, the social benefits may be sufficient to render fair trade a worthwhile endeavor. Where the social advantages offered by fair trade are redundant, however, the economic benefits may be too disappointing to warrant continued participation. This chapter concludes with recommendations for adjusting the structure of fair trade to more appropriately address the needs and goals of it beneficiaries. In addition, I suggest several fruitful avenues for future studies of certification, development impacts, market participation, and value-chain upgrading.

\section{PURPOSE OF THE STUDY}

The research tools of an anthropological study provide valuable insight into the lived experience of economic and cultural changes that are more often discussed in the abstract. Development studies, fair trade studies, certification impacts, commodity chain restructuring, and value-chain upgrading are too frequently discussed solely in terms of theoretical potential for change (Conroy 2007, Lyon 2006, Mutersbaugh 2005, Renard 2005, Talbot 2004). The purpose of this study is to investigate the on-the-ground reality for the subjects of these theories, building on the work of Jaffee (2007) and Utting-Chamorro (2005) by providing real-life examples of producers who are experimenting 
with different forms of engagement with the international market. By connecting theory with experience, these stories reveal not only the "contradictory, messy, and refractory" outcomes (Li 2005) which do not always resemble the logical flow of theory, but also the crucial factors that have been externalized from theoretical conclusions and led to misguided assumptions about development and economic impacts.

Moreover, throughout the course of my fieldwork, I made many promises to many people who contributed their thoughts and experiences that I would share the results of their collaboration with both the communities in this study as well as the decision makers and coffee buyers abroad. It is my hope that, in addition to the academic contributions of this project, the findings of this study will bring some much needed attention to the concerns of coffee growers, helping to improve a well-intended system of trade and provide a voice for the campesinos whom it is designed to help. 


\section{Chapter II: Literature Review}

\section{REDUCING THE "MARKETNESS" OF COFFEE}

Fair Trade as practiced today is rooted in two distinct approaches to development, one charitable and one political (Jaffee 2007). The fair trade movement can be traced as far back as missionaries in developing countries in the 1940s (Fridell 2007, Jaffee 2007, Bray et al. 2002, Grimes 2000, Castillo and Nigh 1998). Fridell (2007) discusses how upon returning from their missions, these trade facilitators recognized a disparity between the time and attention invested in the production of handicrafts and commodity goods versus the meager prices these producers requested for the fruits of their labor. Typical visitors to such exotic locales, particularly developing countries in Africa and Latin America, sought bargains in textiles, jewelry, and even primary commodities such as coffee to sell at a high rate of profit back in their First World homes, where the hand-worked quality, attention to detail, and ties to exotic locations enhanced their retail value. In contrast, the initial members of the alternative trade movement would purchase highly labor-intensive, inherently personal handicrafts from Third World producers at First World prices. They sold goods such as textiles and coffee in church basements, returning to their mission sites with higher profits for their trade partners than would have been possible through either conventional market channels (with their long chains of middlemen) or visiting tourists (who paid in accordance with the local cost of living). 
These informal face-to-face trade relationships grew into Alternative Trade Organizations (ATOs) that sought to reconnect consumers with producers, not only facilitating physical trade, but helping producers to access loans, purchase quality materials, and accommodate customer preferences. In this way, ATOs reflect a reintroduction of the "total social prestations" of production and trade, incorporating the broader social, environmental, and cultural ramifications of production into the value of a traded good (Rosenbaum and Goldín 1997).

The primary objectives of the alternative trade movement, and its fair trade offshoot, were to decommodify goods and their exchange with distant and unfamiliar partners, revealing the social, environmental, and economic contexts of production, and thereby reconceptualizing the value of a good and the ramifications of trade (Lyon 2006, Hudson and Hudson 2004). Jaffee (2007:27) refers to this process as an attempt to reduce the "marketness" of a commodity. Rather than value a product exclusively in terms of disembedded economic value, reducing marketness involves eliminating as many intermediaries as possible to allow producers to communicate more directly with consumers. As a result, consumers learn of the broader impacts of their purchases beyond the simple exchange of goods for money. Direct interaction with artisans privileged the proponents of fair trade to include detailed information about the producers, including the materials and techniques used, the time and effort invested, the lives of the producers, thereby enhancing the retail value of the product (Calo and Wise 2005). 
Aid workers were not alone in their concern for the disadvantaged position of primary commodity producers in the international market. Dependency theorists such as Frank (1969), Cardoso and Faletto (1979), Prebisch (Fridell 2007:31), and Amin (So 1990) indentified a system of "unequal exchange" that continually disadvantaged producers of primary commodities. Classical economists such as Ricardo and Mill had long recommended a path of development built on economic investment in commodities in which a country held "comparative advantage" (Brown 2007, Robbins 2003, Castillo and Nigh 1998, Chenery 1961), typically in primary commodities such as cotton, coffee, or minerals for underdeveloped countries. These countries were typically well endowed with cheap, fertile land, labor "availability", and an appropriate climate for raw material cultivation, allowing for production on an unprecedented scale (Topik 2003). However, the plantation economy characteristic of primary production disadvantages producers by leaving them vulnerable to market price volatility and natural disasters (Conroy 2007, Jaffee 2007, Bacon 2005, Hudson and Hudson 2004, Rice 2003), dependent upon a single raw good that is easily rendered obsolete by technological innovations and synthetic substitutes (Talbot 2004, Rice 2003, Cambranes 1985) or oversupply (Williams 1994, Pendergrast 2000, Mutersbaugh 2005), and unable to either diminish the costs of production or increase the value of the raw product (Brown 2007, Fridell 2007). 
During his term as member of the Economic Commission for Latin America (ECLA), Raul Prebisch refined his theories regarding declining terms of trade as they relate to trade policy, which became the basis for his recommendations as a founding member of the United Nations Conference on Trade and Development (UNCTAD). The organization proposed to correct systematic unequal exchange with "compensatory finance schemes" to support disadvantaged commodity producers in Third World countries (Fridell 2007). Manifest as the first International Coffee Agreement in 1962, this voluntary trade agreement incorporated the biggest producing and consuming countries, including Brazil, Colombia, and the United States with an objective to "'alleviate the serious hardship' to producers and consumers that resulted from extreme price fluctuations" and encourage greater consumption in purchasing countries (Shannon 2009). The signing countries agreed upon a determined the amount of coffee to enter the international market, a target price for participants' coffee, and resolved to maintain a cash reserve to supplement coffee to mediate unpredictable coffee prices in the event of natural disasters or market flooding as well as a "diversification fund" to support producers' efforts to experiment in the production of other crops (Fridell 2007, Calo and Wise 2005, Bryceson et al. 2000:22, Pendergrast 2000).

The goal of the International Coffee Agreement was to make trade "as fair as possible given the demands of Northern consumers" (Renard in Fridell 2007:14) and protect vulnerable producers from the "conscious plundering of 
the global South" (Jaffee 2007:28) made possible through the globalization of markets. The agreements, however, were difficult to negotiate, with the United States reluctantly acquiescing as part of a broader effort to combat the spread of communism (Shannon 2009, Berndt 2007, Topik 2003). But each successive renegotiation became more difficult as the biggest producers continued to subsidize investment in new growth (Pendergrast 2000), member countries protested their market quotas (Topik 2003, Pendergrast 2000, Talbot 1995), quotas prevented small producers from meeting the growing demand for specialty product (Shannon 2009), the fear of communism's spread had diminished (Shannon 2009, Bacon 2005), and market liberalization arose as the new economic panacea (Fridell 2007, Calo and Wise 2005). Consequently, the 1983 Agreement was not renewed upon its expiration in 1989 and coffee growers found their once-stable coffee prices reeling with market speculation (Shannon 2009, Fridell 2007, Jaffee 2007, Bray et al. 2002, Levi and Linton 2003, Pendergrast 2000).

As a commodity traded openly on the New York Commodities Exchange (NYCE), coffee prices reflect anticipated, not actual, supply and demand. Though coffee has attained the status of an inelastic commodity in many consuming nations, with consumption little affected by fluctuations in price (Topik 2003), supply levels and prices to producers vary wildly with speculation by the month, week, or even by the day. News of an impending frost or excessive rains can send prices skyrocketing, while rumors of a bumper crop in a major producing country can drive prices ever lower as 
anticipation grows (Jaffee 2007, Bacon 2005, Topik 2003). Advances in cultivation and harvesting technology allow already major producers such as Brazil to radically increase production, doubling their total output of Arabica coffees over a period of ten years (Bacon 2005, Samper Kutschbach 2003), and countries relatively new to the global coffee market, such as Vietnam, to accelerate production at an exaggerated rate (Ponte 2002). With no ICA in place to limit each country's contribution to global supply stocks, the primary coffee producing countries flooded the market with excessive coffee supplies (Eakin et al. 2006). In the wake of the suspended ICA, the NYCE price for coffee (the 'C' price) reached a low of $\$ .49$ per pound in 1992, only to rebound again in 1997 with a peak C price of $\$ 2.50$ per pound, finally careening again to record lows in the early 2000s (Jaffee 2007, Bacon 2005, Linton 2005).

The perilously low price of coffee combined with producers' disadvantaged market position culminated in a situation researchers have termed "the coffee crisis" (Eakin et al. 2006, Bacon 2005). Coffee producers are inherently disadvantaged in market speculation not only because their basic lack of access to such information or resources with which to respond, but also due to the four- to six-year lag before new plants become fully productive (Topik 2003). With such cryptic and elusive information guiding their primary source of income, coffee farmers found themselves at the mercy of the market. As one farmer in Jaffee's study (2007) study stated, "Having to submit your life entirely to the whims of the coffee market is what powerless really means." 
Surviving the price uncertainty characteristic of the conventional coffee market requires the flexibility to mobilize additional resources to supplement low prices in bad years. With few surplus resources upon which to draw, coffee farmers are pressured to exploit assets essential to the wellbeing of their family and community. In his study of rural livelihood strategies, Bebbington (1999) notes that "in times of constraint, people make choices regarding substitution between different dimensions of poverty." But this substitution employs one resource at the expense of another, and in times of desperation coffee farmers often jeopardize the long-term availability of resources in order to survive the short-term. For example, coffee growers may further self-exploit human capital in the form of family labor, preventing children from attending school. Natural capital may be sacrificed to clear land for cultivation of more sun-intensive crops such as corn in order to ensure subsistence when finances are uncertain (Jaffee 2007). Investment in asset development may be diminished or halted as farmers decrease inputs in coffee production or household consumption, further compromising what may already be inadequate nutrition. Alternately, farmers may tap into social capital, soliciting loans to invest in production or household survival while diminishing future profits (Bacon 2005).

Specialty coffee purchasers had already begun to reconceptualize the retail value of coffee to include external costs of cultivation, offering financial compensation for the protection of resources such as natural and human capital. The Dutch coffee trading organization Max Havelaar was the first to 
use a label to notify consumers that the higher price of their coffee would be passed on to coffee growers to better compensate them for their labor (Fridell 2007, Pendergrast 2000), followed by an emergence of similar but unique national labeling initiatives. Each label guaranteed the social responsibility of coffee production, differentially defined by the respective region of influence and the economic and cultural underpinnings of the labeling country (LeClair 2002). The issues addressed by labeling initiatives ranged from gender equity in decision-making to guarantees of minimum wages, from ethical working conditions to halted clear-cutting of planting areas and minimal use of chemical pesticides, presenting consumers with cacophony of issues in competition for financial support (Fridell 2007, Levi and Linton 2003).

Labeling organizations proliferated internationally, and consumers were pressed to decide which cause was most important - environmental sustainability, social responsibility, or economic fairness. The cacophony of messages overwhelmed consumers who were uncertain as to which organization would most effectively benefit producers and pitted labeling organizations in a counterproductive competition for consumers. Driven by the disappointing demise of the ICA and the subsequent vulnerability of coffee growers, the fair trade movement intensified efforts to exert more significant pressure on the mainstream market (Levi and Linton 2003). The movement saw a solution in unifying all the various production and trade concerns under a single label. Rather than prioritize one cause as more worthy than another, and to consolidate all these socially conscious consumers into a single 
consumer base, the new Fair Trade label would guarantee respect for a triple bottom line of environmental, social, or economic concerns. This transition marked a turning point in fair trade, as both charitable and political solidarity groups sought to educate consumers about the plight of vulnerable coffee workers and appeal to their sense of social responsibility.

The first game changer: from "fair trade" to Fair Trade ${ }^{\mathrm{TM}}$

To amplify the voice of the fair trade movement in the arena of mainstream market retailers (Levi and Linton 2003, Bray et al. 2002), 17 alternative trade organizations unified in 1997 under the single, allencompassing Fair Trade Labelling Organizations International (FLO) (Fridell 2007, Jaffee 2007, Renard 2005). It is important to note that from this moment, the distinction can be made between fair trade, a concept or a politicaleconomic movement, and Fair Trade proper, the particular form of fair trade practiced and promoted by the Fair Trade Labelling Organization. The Fair Trade label attributed to FLO allowed the movement to present consumers with a consolidated message (Levi and Linton 2003) of the environmental, social, and human capital invested in coffee cultivation that were previously ignored, or "externalized", in the parlance of economics. As Nash (1979:6) explains they were "extraneous to rational market exchange.... just another factor of production" and therefore excluded from the retail value of coffee. The FLO label informed consumers that a good was higher priced due to the social, environmental, and economic compensation involved in the exchange of a certified good (Calo and Wise 2005: 8). 
Seeking to assure consumers that the diverse concerns of all the associated labeling initiatives were being addressed, FLO designed a system of minimum requirements and progress goals incurred with certification as a Fair Trade grower or purchaser (see FLO 2006). First, in the case of producer groups, growers must be organized in cooperatives comprised of small-scale family-based growers. Second, the cooperatives must be governed by a democratic decision-making process.

In addition to the basic requirements that have to be met in order to receive initial certification, producers are expected to demonstrate effort to achieve progress goals outlined in FLO's Generic Fair Trade Standards and evaluated annually. Due to its heritage as a collaboration of diverse alternative trade organizations, FLO recognizes the triple bottom line of social, economic, and environmental criteria to correct a complex system of unequal exchange. In practice, however, the first two criteria prove difficult to translate into empirically verifiable actions. Social goals in the Generic Fair Trade Standards effective from August 2009 to May 2011 include fostering more transparent and democratic decision-making as well as nondiscrimination in employment. Socioeconomic goals are even less specific, requiring simply that "the organization should take gradual steps to assume more control over the entire trading process." To accomplish this goal, FLO standards state, "Direct communication and negotiation with buyers,... or adding value by establishing processing facilities and/or shared ownership with other producer organizations (horizontal integration)... may be strategies for graduation 
assuming more control over the trading process and supply chain." Environmental goals, however, comprise the bulk of the progress requirements, with reference to specific cultivation practices to be abandoned or adopted, including use of agrochemicals and genetically modified seed, waste disposal practices, and soil and water treatment (FLO 2009).

In return for their efforts in meeting certification requirements, producers receive a fixed rate of $\$ 1.40$ per pound of Arabica coffee, reflecting a price increase effective April 1, 2011 from the original Fair Trade price of $\$ 1.21$ per pound. Additionally, the producer cooperative receives a $\$ .20$ per pound Fair Trade premium and potentially another $\$ .30$ per pound premium if the coffee is also certified organic, for a possible total of $\$ 1.90$ per pound of Fair Trade and organic certified Arabica coffee. The premiums are returned to the producer cooperative and intended for use in community development projects such as scholarships or clinic construction (FLO 2011b).

Compelled by the guaranteed price, particularly appealing in wake of an inevitable market dip, the number of coffee growers seeking certification outpaced the growth of the fair trade market niche. Founding member cooperatives, by virtue of the strength of their relationship with importers and roasters as well as their higher level of organization, are able to sell over half of their harvest through Fair Trade channels (Renard 2005). New member cooperatives, on the other hand, found their production volumes in excess of the amount their purchasers could conceivably sell (Taylor 2003). As a result, the average certified farmer is only able to sell about $20 \%$ of their annual 
coffee production as Fair Trade (Berndt 2007, Fridell 2007). Furthermore, growth in FLO certified coffee sales came to a standstill in 1999-2000 (Fridell 2006), leading some players in the fair trade movement to reevaluate their role in the conventional market.

The second game changer: Fair Trade goes mainstream

In an effort to increase product sales, members of the fair trade movement sought avenues to increase the presence of Fair Trade certified coffee amongst conventional coffee options (Murray et al. 2006). Consolidation under the FLO umbrella served to create a unified message and consumer base among socially conscious consumers, but the fair trade movement was preaching to the choir without bringing new consumers into the fold. The FLO perceived their challenge as breaking out of a niche market, generating more awareness of the unfair terms of trade presented to coffee growers, thereby increasing demand for fair trade coffee and allowing the benefits of certification to reach a greater number of farmers. After all, the original vision of fair trade sought to alter the strictly economic and impersonal valuation system for commodities (Renard 1999), aiming to change not only society's values (Golding and Peattie 2005) but also to make the practices of the mainstream market more fair (Jaffee 2007). Viewed as a challenge of increasing demand to meet supply, the focus of the movement shifted from a mission-driven to market-driven approach (Raynolds 2009), from creating alternative market structures to using the structures of the market as a tool for the movement. 
Belying the mainstream market participation scheme is the hope that that the "certification revolution" will pressure companies to adopt the standards of more socially responsible commodity trade (Conroy 2007). Functioning as a "buycott" movement, the certification revolution proposes to man the helm of supply and demand, supporting businesses that exhibit socially conscious sourcing practices and pressuring multinational corporations (MNC) to meet their demand for certifiably ethical products (Neilsen 2010, Fridell 2007). The threat to tarnish a carefully crafted brand image can be an effective weapon against retail giants (Conroy 2007, Esty and Winston 2006, Mutersbaugh 2005), and with this in mind, representatives from the social activist organization Global Exchange mounted escalating pressure on big market players such as Starbucks to commit to purchasing FLO certified coffee. The year-long campaign culminated in April 2000 with the coffee retail giant signing a letter of intent with TransFair USA, FLO's representative organization in the US, to offer Fair Trade coffee in all its US cafes (Conroy 2007, Macdonald 2007, Linton 2005). Fair Trade Labelling Organizations itself courted distributor giant Carrefour, winning a 10-year commitment to purchase organic coffee directly from a FLO certified cooperative, with packages sporting a non-fair trade "Bio Mexique" label (Raynolds 2009, Renard 2005).

While hard-won purchasing commitments may have a positive impact on the amount and price of coffee purchased from Fair Trade growers, not all members of the fair trade movement welcome these new MNC partners with 
open arms. Certain members of the fair trade movement question the impact such deals will have on the market-breaking goals of the movement, as well as the survival of smaller Fair Trade roasters and retailers (Jaffee 2007, Mutersbaugh 2005). Fair Trade Labelling Organizations may be able to pressure MNCs into cooperation through PR campaigns for social responsibility, but the trade relationship is still one of negotiation, with MNCs making their own demands of quality and services (Raynolds 2009). According to Paul Rice of TransFair USA, certification organizations are now wrestling with two primary challenges: to provide certification services "at the speed that those companies want to move" and to "wrestle with the complicated interaction" between advocacy organizations and the engaged companies (Conroy 2007).

The second defining moment in the evolution of fair trade occurred when, in 2002, FLO created FLO-Cert, Ltd. as a third-party certifier (Fridell 2007: 55). On the one hand, this lent credibility to FLO's Fair Trade Label and assured that certification could occur in a timely fashion, which, as Conroy (2007) points out, was essential to FLO's increasing courtship of the mainstream market. On the other hand, it has placed greater distance and an additional layer of bureaucracy between producer cooperatives and their trade partners, and imposed a greater financial burden on producing communities in the form of certification and inspection fees (Jaffee 2007, Parrish et al. 2005).

Much as the agglomeration of labeling initiatives under the FLO umbrella marked a change in how fair trade was practiced, the partnership of 
FLO with MNCs has initiated another transformation in the definition and act of certified Fair Trade. In transitioning from a self-regulated and self-certified movement to an "institutionalized certification system", fair trade took a second step further away from a collection of face-to-face trade relationships to support situation-specific development goals, transitioning into what Taylor (2005) terms a "depersonalized niche market plan" with "market-friendly" goals (Fridell 2007). To support this new plan, FLO continues to invest more time and resources in broadening what Fridell (2007: 23) calls the "fair trade network", distinct from the fair trade movement in its absence of a political agenda.

Though the mainstream tactic has been championed by the world's largest provider of fair trade certification, not all members of the fair trade movement are on board with FLO's new approach. Tensions have risen within the fair trade movement as participants divide over the future trajectory of their efforts. Fridell (2007), Jaffee (2007) and others (Conroy 2007, Renard 2005) have identified the following two options: foster producers' capacity for knowledgeable market competition, or negotiate alternative market structures. Researchers have termed the latter direction an alternative globalization (Fridell 2007) or market-breaking (Jaffee 2007) approach, which calls for ICAlike market regulation and protections for disadvantaged Third World market participants. The former vision, on the other hand, has been termed a shapedadvantage (Fridell 2007) or market-reform (Jaffee 2007) approach, preparing 
coffee producers to be more effective and independent players in the global market.

Another shade in the spectrum of fair trade is what Raynolds (2009) terms "mission-driven" approach practiced by enterprises like Equal Exchange. These organizations espouse the alternative globalization perspective, challenging the rational logic of the global market and reintroducing the previously externalized environmental and social costs of production. Like their "market-driven" counterparts, they use FLO certification as a means to enter conventional markets. Mission-driven organizations, however, strive to retain the original ATO model, sometimes forgoing certification altogether to base their credibility in ensuring "fair" trade on their intimate knowledge of and personal interaction with coffee producers (Fridell 2007). In contrast to MNCs like Carrefour and Starbucks, these organizations maintain the promise to sell only fair trade products.

Perhaps the most widely recognized example of a mission-driven fair trade organization, Equal Exchange sells 100\% fairly traded products. As a cooperatively owned business, Equal Exchange applies the similar principles of fairness and transparency to its own practices as employer and prides itself on trading "directly with democratically organized small farmer cooperatives." (Equal Exchange N.d.a) Rather than work within the system of FLO certification, Equal Exchange is a member of the Fair Trade Federation, "a membership organization limited to $100 \%$ fair trade companies." Unlike FLO, the Fair Trade Federation does not provide certification or a label. Instead, 
member organizations are admitted on the basis of "three peer reviews from existing members or highly regarded groups such as FLO certified farmers." According to Dean Cycon of Dean's Beans, "application reveals who you buy from, how you buy, what you know about the living standards of those from whom you buy and what impacts your work has." (Dean's Beans 2011)

Mission-driven organizations have decried the courtship of MNC partners as these retailers have a heavily weighted influence on the direction of FLO practices with little commitment to the underlying principles of the movement (Raynolds 2009, Jaffee 2007). As Barrientos et al. (2007) aptly stated, "Fair trade advocacy NGOs question in particular whether the basic concept of Fair Trade is being 'bastardized' by its mainstreaming in shops and restaurant where most of the products being sold are not ethically certified and where there are major ethical questions being raised about other aspects of the firms' business practices.

\section{From re-embedding to dis-embedding}

While this transition may have been essential to FLO's goal of mainstream market participation, many have lamented FLO's subsequent distance from the initial alternative trade goals of the fair trade movement. Alternative trade was developed from the idea of reintroducing the "total social prestations" of production and trade, incorporating the broader social, environmental, and cultural ramifications of production into the value of a traded good (Rosenbaum and Goldín 1997). The term "prestations" was first introduced into the English-speaking anthropological world through 
translations of Mauss' The Gift in 1954, referring to "the actual act of exchange of gifts and services, and the reciprocating or return of these gifts and services." (1990:vi) For consumers of fair trade goods, then, recognizing prestations implies knowledge of the social context of producers. Fair compensation would be determined according to the social and environmental significance of trade. Murdoch et al. (2000) describe this value-adding process as "re-embedding," or resituating goods within their context of production. In contrast, MNCs operate in according to the logic of supply and demand. As a result, MNCs required of FLO a commodity that appealed to the lowest common denominator, with the broadest market appeal in order to generate the broadest support base possible and satisfy the mainstream market's demands for smooth and rapid exchange of goods, services, and capital.

Upon entering the mainstream market, FLOs services and products must be rendered generic and interchangeable to suit the specific needs of MNC retailers. Mainstream roasters and retailers prefer less specificity in the characteristics of retail goods, as the unique qualities of a product can inhibit profitable supply and demand manipulation. Rather than single-origin coffees with particular flavor characteristics, they need blendable beans with generic flavor profiles and a single fair trade message to occupy the allotted fair trade space on store shelves (Daviron and Ponte 2005). In a reversal from the reembedded, socially contextualized qualities originally associated with fair trade, Fair Trade goods must be once again dis-embedded in order to enter the mainstream market. Any superfluous traces of local conditions, such the 
name of the community in which coffee was grown or the flavors characteristic of a specific region, must be eliminated to create a more generic and substitutable product. To accomplish this, the "social natures" of certified goods "are polished smooth, removing discordances" (Ogden 2008:224). Though Ogden uses Latour's term "smooth object" to describe ecological sites that have been rendered "devoid of their inherent material and ideological conflict, incongruities, and biosocial entanglements," FLO certified projects undergo a similar process. In the case of fair trade coffee, the process of "generification" requires the reworking of product descriptions sufficiently distant from the ground level that they may be applied in a variety of settings. Each divergence from the generic Fair Trade product, each unique quality of producers and their cooperatives, each area-specific trait that once designated the uniqueness of each commodity exchange now represents a potential bur on a commodity that can complicate their smooth flow through the mainstream market.

At the same time, Fair Trade goods must also retain a modicum of social context to continue meeting the demands of socially conscious consumers. Preserving re-embedded qualities necessitates a balance to be struck between certified products that are neither too "weighed down" by the particular context of production nor completely "disembedded" from their context and alienating the long-term consumer base (Murdoch et al. 2000). Thus the Fair Trade practice underwent a process of negotiating what Latour calls "modalities", where "heterogeneous relations are bundled together... 
complexity disappears and we are left with simplified categories." (Murdoch et al. 2000, Latour 1987). The result is a simplified message of a Fair Trade coffee from a given country, or even region, that will benefit producers by giving them a "fair" price, with none of the specifics of the community or the producers that formerly worked to decommodify trade. The disembedding process is apparent in the rubric of certification requirements, such as cooperative organization of producers (Luetchford 2007), applied to all certified producers even where they may not be culturally appropriate, as is the case in some countries in Africa where cooperative organization is perceived as a threat to government authority (Brown 2007).

\section{RATIONALIZING THE DECIDEDLY IRRATIONAL}

Much as some Fair Trade goods have been polished smooth and stripped of their social context, the certification process has also been smoothed, eliminating attention to detail so that it, too, can be applied in a broader variety of settings. The smoothing process can be understood as "routinization" (Talbot 2002) or, drawing upon Weber's writing on bureaucracy, "rationalization," wherein processes are made more efficient and productive by limiting their scope to "rational" action with predictable means and ends. In order to reach more producers and incorporate MNC retailers more quickly into the fair trade network, the certification process had to become more rational, treating all cooperatives as sufficiently uniform that a single set of standards could be rapidly assessed in all possible settings. 
By necessity, FLO undertook this process by creating the third-party certifier FLO-Cert Ltd. to meet the expediency and accountability demands of the MNCs it courted. The face-to-face interactions and consideration of "fair"ness according to the context and setting of each particular site presented additional burs to the certification process. At the behest of MNCs, certification was revamped to employ a more impartial third-party arm of evaluation, FLOCert Ltd., accomplishing both demands of impartiality and expediency (Conroy 2007, Fridell 2007: 55). However, in order for a third-party to conduct evaluations, certification requirements must be translated into a rubric straightforward and generalizable enough to be applied anywhere by anyone.

The process applied to certification recalls the careful organization and quantification of the German forests Scott describes in Seeing Like a State, where the goal was to be able to "read" the forest "accurately from tables and maps" while "the forest itself would not even have to be seen." (1998:15) With the creation of FLO, fair trade transformed from a case-by-case definition to a globally-applicable definition and system of evaluation. Taking another step away from the individual and toward an ideal, the creation of FLO-Cert Ltd. is intended to expedite evaluations, arming unbiased evaluators to enter a totally unfamiliar environment and quickly assess the presence or absence of required conditions. Indeed, researchers investigating the impacts of Fair Trade have found producers to note a decline in the frequency of visits from Northern trade partners after FLO's "mainstreaming strategy" went into effect 
(Taylor 2005), again sacrificing a defining characteristic of fair trade for the sake of smoother functioning in the conventional market.

Thus, by situating itself as a competitor in the mainstream, Fair Trade attempts to straddle the line between rational and irrational market exchange. It uses rational market logic of increasing demand and limiting supply to reintroduce "irrational" elements of exchange, educating consumers about the plight of the underprivileged coffee worker to accomplish its goals of pulling more coffee farmers out of poverty (Gresser and Tickell 2002).

Finally, if the goal of Fair Trade is to incorporate a greater number and variety of players in the fair trade network, then the development mission of Fair Trade must also be reconfigured to appeal to a broad swath of potential trade partners and consumers. The message must offer the opportunity to be part of the solution rather than implicate trade partners as part of the problem. To blame a system of "unequal exchange" in which MNCs take advantage of trade conditions in developing countries would not go far in winning the cooperation of a retail giant such as Starbucks. Moreover, consumers need to know that their financial support is a definite solution to the problems faced by coffee growers. Less encouraging is the case that a higher price for coffee is helpful in the short-term but insufficient to pull growers out of poverty as long as they are systematically disadvantaged in international trade.

Examining this process of "polish[ing] smooth" and "removing discordances" in the specific context of development schemes, Tania Li uses the phrase "rendering technical" to describe the way in which a multifaceted 
problem is made "amenable to a technique" of resolution (2005:389). Building upon Ferguson's 1994 work, The Anti-Politics Machine, which examines the process of designing a "technical 'development' intervention," Li explains that the primary objective of rendering technical is to distill the development problem into a bounded, easily definable, and resolvable challenge. Therefore, the definition of the problem is confined to those things that can be affected by a development intervention, so the intractable system of global inequality is excluded from the presentation. In the same vein, the solution to the problem is limited to acts within the capacity of the development agency to conduct, meaning questions such as the long-term viability of coffee cultivation as a source of income are best left out of the solution discussion.

\section{Rendering technical the Fair Trade practice}

Inherent in the act of rendering technical is the objective of rendering an intervention site and strategy as apolitical as well (Li 2007:7). Political concerns are generally out of reach for development agencies, therefore they cannot be succinctly defined or easily resolved. Structural issues such as political and economic systems both elude simple solution and have potential for alienation of supporters. But while an apolitical definition of and technical solution to development may enhance the efficacy of an organization to generate sympathy for a cause, it also compromises the organization's ability to effectively accomplish development goals. As Li explains, "an important reason promised improvements are not delivered is that the diagnosis is incomplete... it cannot be complete if key political-economic processes are 
excluded from the bounded, knowable, technical domain." (2007:18) Key political-economic processes have certainly been shed along the path leading FLO from a collective of alternative trade organizations to its current position as foremost Fair Trade ${ }^{\mathrm{TM}}$ certification agency.

Fair Trade Labelling Organizations inevitably supports its development agenda by soliciting purchasers via the broadest possible avenues for entering the market. Though advantageous in its ability to generate more funds for development, this strategy is flawed in that the 'rendered technical' version of fair trade required to compete in the conventional market also overlooks many of the key political and economic questions crucial to a cooperative's success in achieving development goals. As Lyon (2006:460) points out, certification requirements are "often abstracted from the social and political contexts of workers' everyday lives."

Coffee producers have actually had little involvement in either determining what is meant by Fair Trade or setting the course for development outlined in the progress requirements for certification. Lyon (2006:460) has noted the "low level of producer participation in international decision-making", where the power in goal-setting still rests primarily with representatives of the developed global North (see also Jaffee 2007, Luetchford 2007). In fact, FLO's goals and requirements have been heavily skewed toward environmental protections, despite the fact that producers consistently cite obtaining more money for their coffee and eliminating middlemen as their primary motivation for participating in Fair Trade (Jaffee 2007). Li describes the part played by 
FLO in guiding development as that of "trustee", whose role is "not to dominate others - it is to enhance their capacity for action, and to direct it." (Li 2007:5) In FLO's own words, their intention is that "Fair Trade should lead to the demonstrable empowerment and environmentally-sustainable social and economic development of the producer organization and its members, and through them of the workers employed by the organization or by the members, and the surrounding community" (FLO 2011a). Fair Trade Labelling Organizations is merely the director and enabler of development, as well as designer of its course.

While Li builds her own understanding of development upon Scott's examination of development gone wrong, rather than continue his assertion that "Certain Schemes to Improve the Human Condition Have Failed", Li instead chooses to focus on identifying the "knowable, technical domain" and overlooked political-economic processes that result not in failure so much as "contradictory, messy, and refractory effects" (2005:391). Attempting development work with a narrow eye to the causes and solutions of poverty invariably produces unforeseen effects, as the confounding variables belying the situation have been intentionally excluded from cause-and-effect calculations. But unlike Scott, Li illuminates the consequences of development rather than condemning a project to failure simply because the technical solution did not produce results precisely as anticipated.

To highlight "the gaps between plans, claims, and 'facts on the ground' that compromise the ability of a development scheme to effectively bring about 
proposed change, Li (2005) suggests "the effects of planned interventions have to be examined empirically, in the various sites where they unfold families, villages, towns, and inside the bureaucracy, among others." Similarly, researchers of the impacts of Fair Trade have called for more comparative studies with "attention to context" and more "in situ fieldwork" (Mayoux in Parrish et al. 2005). The small but rapidly growing body of case studies investigating the impacts of Fair Trade certification consistently supports Li's assessment of the development enterprise in general: Fair Trade brings some benefits and some disappointments, unintended consequences and unanticipated outcomes (Ronchi 2002), all largely dependent on the "key political-economic processes" (Li 2007) or pre-existing conditions (Raynolds et al. 2004) that are often excluded from FLO's technical rendering of the populations they intend to help.

The unanticipated consequences of Fair Trade

Fair Trade Labelling Organizations has sponsored a limited number of impact studies (Murray et al. 2006, Milford 2004, Ronchi 2002) which have generally found Fair Trade to have a significant positive impact on producers and their communities. Case studies documenting on-the-ground impacts of Fair Trade certification in Mexico (Jaffee 2007, Raynolds 2002), Nicaragua (Fisher 2007, Bacon 2005, Utting-Chamorro 2005), Costa Rica (Luetchford 2007, Ronchi 2002, Sick 1999), Guatemala (Lyon 2007), Tanzania (Parrish et al. 2005), and other developing countries with significant coffee export 
industries have found many benefits to Fair Trade, some intended and some unexpected.

While environmental practices are the most detailed of certification requirements, evaluating their impacts on environmental perspectives has proven particularly challenging. First, the environmental requirements for FLO certification and the quality demands of the international market often pressure Fair Trade producers to seek dual-certification (Calo and Wise 2005). According to Raynolds (2002), about $80 \%$ of Fair Trade certified coffee sold in the US is also organic certified, thereby muddying an investigation of impacts and confounding those outcomes attributable to Fair Trade alone. While in this study, I discuss the financial complications that result from organic requirements, they are treated as a subset of fair trade requirements, since organic is increasingly part and parcel with fair trade.

Furthermore, Bray et al. (2002), Jaffee (2007), and Bacon (2005) have demonstrated that producers are primarily concerned with environmentally responsible growing practices insofar as they have positive economic ramifications, such as saving money on chemical inputs and receiving organic price premiums, less commonly noting benefits to human and environmental health. The reaction to environmental impacts highlights a "messy" outcome of Fair Trade, where certification might affect growing practices but without imparting in producers the environmental awareness to support their continuation in the absence of financial incentives. 
Outcomes are also messy in the realm of social development, where price premiums are intended for use in development projects within the community. Education access is often noted by researchers as a primary benefit of certification (Jaffee 2007, Utting-Chamorro 2005, Ronchi 2002) but raises further questions as to the quality of education, the economic impact of added school expenses, and the impact school attendance has had on households in which children constitute vital members of the non-paid family workforce (Pendergrast 2000). In another example, simple audits of the presence or absence of democratic governance structures often overlook the "refractory" nature of outcomes such as quality of participation of men and women. Researchers have noted the tendency among inspectors to talk primarily with male community members (Lyon 2007), the disjuncture between elected officials' and non-officiating cooperative members' understanding of fair trade rhetoric and profit distribution (Bacon 2005, Utting-Chamorro 2005), and the prevalence of machismo preventing women from expressing their own opinions (Utting-Chamorro 2005).

Finally, the significance of political-economic questions is evident when evaluating the actual benefits most frequently cited by certified communities organizational capacity building (Bray et al. 2002, Raynolds 2002) and social capital accumulation (Bacon 2005). These outcomes have been observed primarily in regions with a history of government supported cooperative living, such as Southern Mexico and Nicaragua and may not be as readily achievable in regions lacking such experience. 
Researchers have noted "contradictory" outcomes where the financial benefits anticipated by producers are being offset by costs incurred in meeting certification requirements or obscured by the system of payment. Fair trade impact studies tend to evaluate financial impacts by comparing international prices with prices received by fair trade cooperatives (see Berndt 2007, Bacon 2005, Calo and Wise 2005, Ronchi 2002). While such a comparison of gross income alone often suggests increased profits for Fair Trade producers, the few studies that have pursued economic impacts beyond the cooperative and into the homes of producers (Jaffee 2007, Utting-Chamorro 2005) have found that actual net income differences are negligible. As Jaffee (2007) notes, despite the minimum FLO price guaranteed to producers worldwide, the actual price that reaches the grower varies regionally as a result of costs of production, especially labor costs, and cooperative structure. Though Fair Trade is intended to provide predictability and a fair price in an otherwise wildly fluctuating conventional market, the price stability function can be a disincentive when conventional prices approach or even exceed the FLO price (Jaffee 2007), especially since Fair Trade requirements necessitate a greater labor investment. Furthermore, though Fair Trade per pound coffee prices are set to be higher than conventional prices, the portion of the "farm gate" price ultimately received by producers can be significantly less (Utting-Chamorro 2005). Financial gains can be diminished by debt (Utting-Chamorro 2005), strains on time in the form of labor inputs (Jaffee 2007, Bray et al. 2002) and meetings (Jaffee 2007), increased labor costs both for coffee and milpa 
cultivation (Jaffee 2007), and processing fees deducted by the cooperative (Utting-Chamorro 2005). Moreover, while producers understand that the key to capturing more of the value added to coffee is by the elimination of middlemen, they have begun to refer to Fair Trade as the new middleman. With the advent of FLO-Cert., its Local Liaisons, and other bureaucratic institutions (FLO 2006), FLO has inserted new layers of bureaucracy in the exchange between producer cooperatives and consumers (Renard 2005). Additional fees have accompanied these services (Conroy 2007, Parrish et al. 2005), and producers have begun to discuss Fair Trade channels as coyote networks, or the very intermediaries they intended to omit.

In the eyes of many shaped-advantage minded researchers, as well as coffee producers, this final point has become the crux of the fair trade movement. In understanding what Daviron and Ponte (2005) have termed "the coffee paradox," many have turned their attention to the structure of commodity chain linking coffee producers to coffee consumers. The coffee paradox describes the effects of coffee's inelastic demand as experienced by producers, specifically the steady demand and increasing value of coffee accompanied by fluctuation of prices paid to producers in a relatively low range of conventional market prices. Producers, too, are vaguely aware of this phenomenon, and tend to react with shock and puzzlement upon learning the by-the-cup price of coffee sold in developed countries (Lyon 2006). Producers often express their hope for more "direct trade" with coffee purchasers, 
eliminating more of the middlemen of trade, as a means of increasing their profits.

\section{One Step Forward, Two Steps Backward}

The alternative trade roots of the fair trade movement are barely recognizable in Fair Trade as it is practiced today. By throwing their lot in with conventional market peers, Fair Trade necessarily underplayed its mission to create alternative market structures and distanced itself from the "fair"ness verification process. Rendering technical the development situation approached in FLO's version of fair trade meant shedding the rhetoric of combating a system of unequal exchange, as well as cooperating with the time and quality demands of new MNC partners. Researchers and producers alike are concerned that the mainstream trajectory of Fair Trade constitutes a greater sacrifice than is offset by the gains. To highlight the sacrifices of fair trade principle FLO has made in pursuing its market-driven objectives, commodity chain analysis illustrates both the diversion from direct trade as well as the distraction from overcoming unequal exchange that occurred with the organization's transformation.

Commodity chain analysis, a means of examining the network of labor and production processes whose end result is a finished commodity (Hopkins and Wallerstein in Gibbon et al. 2008:316, Gereffi and Korzeniewicz 1994), identifies the quality demands, flexibility (Daviron and Ponte 2005), distribution of risks (Jaffee 2007), and opportunities to increase product value and collect economic rents characteristic of each participating firm (Bacon et al. 2008:2, 
Talbot 2004:19). In a conventional commodity chain, coffee passes through myriad different firms, including processors, exports, brokers, and distributors, before reaching the hands of the final consumer.

Figure 2.1 General structure of the global coffee-marketing chain

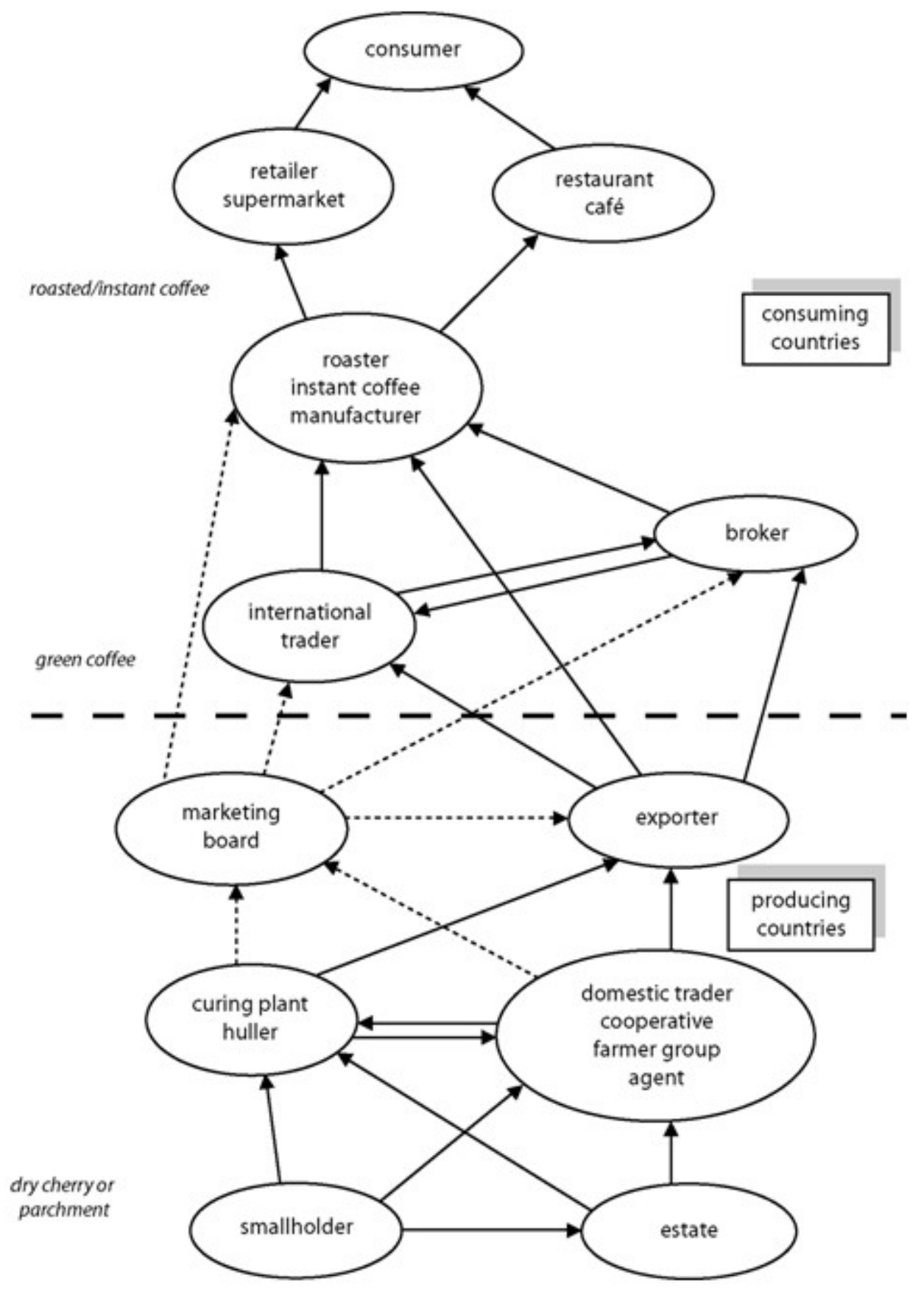

(Ponte 2002) 
For this reason, many who promote the fair trade movement on the basis of the original ATO mission of directness do so not only for purposes of decommodification of the product, but also for economic reasons. Organizations such as Roundtable Roasters, Catholic Relief Services (CRS), and FLO compare the structure of their commodity chain to that of the conventional system, suggesting that fewer firms separating producers from consumers will translate into greater profits retained by producers. The assumption is that the greater the number of firms involved in bringing coffee from producer to consumer, the more deductions are made from the coffee price before profits are returned to the growers.

Contrary to the idea of fair trade as direct trade, the new mainstreamamenable model of Fair Trade positions an additional firm, FLO-Cert Ltd., in the commodity chain. Not only does this pose an additional barrier between producers and consumers, further depersonalizing their interaction, but now growers are required to pay annual certification fees to cover expenses accrued in the evaluation process (Jaffee 2007). Researchers and proponents of the mission-driven alternative trade movement have decried the modification to the Fair Trade system, as it shifts the focus of fair trade from protecting farmers and granting them market access to creating additional barriers to trade and charging a fee for specialty market access (Renard 2005). In fact, in many ways, certification systems can be seen as perpetuating the system of "unequal exchange" by maintaining a position of authority and dominance in allowing market access and controlling the 
processes through which the quality that coffee producers add is translated into added value.

While advocates of fair and direct trade suggest limiting the number of firms in the commodity chain to return greater profits to producers, shortening the chain alone is not sufficient to achieve a primary goal of the fair trade movement, to affect the global system of unequal exchange. Rather than simply receive a higher price, a more "equal" form of exchange would alter the portion of the retail value returned to producers, incorporating them into more value-adding tasks of production rather than confine them to tasks that are continually devalued, such as raw material production.

Building upon the concept of commodity chain analysis, global value chain (GVC) analysis illustrates the power dynamics of firms involved in the commodity chain and how value is accrued during each stage of production (Daviron and Ponte 2005:26). By identifying how value is added to a commodity, GVC analysis illuminates the opportunities for forward-integration by “upgrading into 'higher' positions (in terms of technology, value-added, or operational scale)" (Daviron and Ponte 2005:26), as well as prospects for resuming control over activities that occur further downstream in the commodity chain (Fridell 2007, Talbot 2004, 2002). Forward-integration of producers in the GVC, then, involves altering both the quantity of firms in the commodity chain as well as the quality of nodes, or stages of production, in which producers participate (Fridell 2007, Daviron and Ponte 2005, Gereffi and Korzeniewicz 1994). Rather than assist producers in upgrading their tasks 
in the GVC, the mainstream-accommodating version of Fair Trade not only adds additional links - certifying agencies, additional stages of warehousing and retailing - but also alters the demands placed on producers, further obscuring consumer feedback and value-adding tasks - processing and marketing - that are necessary to their forward-integration in production.

\section{AFFECTING THE POWER STRUCTURE OF TRADE}

For a continually oversupplied and undervalued raw good such as coffee (Fridell 2007), the ability to profit in trade lies with those who can manipulate scarcity and barriers to market entry (Bacon et al. 2008), ascribe symbolic quality (Renard 1999, Castillo and Nigh 1998), or perform other tasks typically controlled by roasters and retailers in Northern markets (Fridell 2007:126). These firms are best prepared to capitalize on market speculation, by both disguising product flaws as well as enhancing perceived quality (Daviron and Ponte 2005:35). Coffee roasters can respond to supply fluctuations by marketing coffee blends rather than single origin coffees or, alternately, marketing the same supply from different angles, changing the labels to reflect seasonal blends, flavored blends, or "sustainable" production practices (Daviron and Ponte 2005). For this reason, large mainstream retailers demand high volumes of cheap, nondistinct, blendable beans with a flavor profile generic and flexible enough to be use in a variety of products (Samper Kutschbach 2003:128, Topik 2003:23).

Meanwhile, discriminating tastes along with increased environmental and social sensitivity have generated new interest in coffee grades and 
categories, creating opportunities for market segmentation and product differentiation (Calo and Wise 2005, Topik 2003: 23-24). In burgeoning specialty coffee markets, consumers pay higher prices for coffee characterized by certain flavor attributes or "sustainable" production practices (Daviron and Ponte 2005). One way roasters can respond to this new market opportunity is by emphasizing certain material quality attributes, those that "can be measured using the human senses...or by mobilizing sophisticated technological devices." (Daviron and Ponte 2005:34-35) These may include flavor, aroma, size, shape, and color. Additionally, roasters can promote symbolic quality attributes of coffee, those that "cannot be measured" and may include "trademarks, geographical indications, and sustainability labels." (Daviron and Ponte 2005:37)

\section{Lucrative potential of quality}

For consumers of coffee, material quality has traditionally varied only in such simple terms of climate-specific Arabica versus easier to grow, lower quality, more caffeinated Robusta coffee species, the two distinguishable primarily in terms of price (Samper Kutschback 2003). Material quality, which is embedded in the measurable traits of the coffee bean itself, has become an area of increasing differentiation as coffee roasters define new desirable characteristics in terms of aroma, color, and flavor. These qualities are "measured" in brewing and tasting facilities called "cupping labs," where trained evaluators sample and rate coffee according to a standardized and internationally recognized ranking system, ranging from commercial quality to 
super-specialty coffee, and with descriptors such as "red apple acidity" and "cardamom spice aroma" (Coffee Analysts 2008), similar to the sensory analysis science of wine tasting (Daviron and Ponte 2005:130). Material quality has become an area of increasing commercial importance and could present an opportunity for coffee producers to add value to their product, as coffee consumed alone, without the added milk and sugar of a coffee drink, holds nearly infinite opportunities for differentiation and discrimination in taste (Topik 2003:24).

Symbolic quality is embedded in the context of production and trade. These qualities cannot be measured or identified without knowledge of the geographic origin of the coffee, nor do they translate into added value without the reputation of a brand, sustainability label, or trademark that allow consumers to purchase an "enterprise", a "place," or an "ethic" (Daviron and Ponte 2005:37). Rent-capture through added symbolic quality is viewed to be a more dynamic source of value, as material value can always be replicated or substituted to dilute the value it is capable of adding while symbolic quality is a fixed characteristic of resulting from cultivation and trade (Bacon et al. 2008:15). For this reason, Daviron and Ponte (2005) suggest that an Indication of Geographic Origin (IGO), akin to those granted champagne, Scotch whisky, and buffalo mozzarella, might help coffee producers collect rents on the symbolic value and reputation of their coffee. Roasters, however, have become hesitant to build symbolic value around particular locations such as cities or even countries due to the need for flexible supply chains and 
interchangeable coffee beans, as evidenced the recent struggle between Starbucks, the U.S. National Coffee Association, and Ethiopian coffee farmers who attempted to trademark Ethiopian yrgacheffe, harrar, and other reputable, regional coffees (Oxfam N.d.).

Instead, roasters focus on developing the symbolic value of their brand and regional blends, seeking technological advances that allow them to render beans generic by obscuring too-specific flavor traits and creating components that can be substituted as necessary in reaction to changes in price or supply (Daviron and Ponte 2005: 93-95). Murdoch et al. (2000) refer to these processes as "appropriation" and "substitution", efforts to reduce the importance of nature by replacing natural processes and products with industrial activity, and they allow transnational corporations and coffee roasters to suppress the symbolic quality that would otherwise be add value to the raw product.

\section{Bringing growers into the value-adding fold}

Coffee producers are, by virtue of their role in the GVC, privy to the information that adds material and symbolic quality to specialty coffee. Smallscale coffee production is well-suited to the specialty industry, since the altitude, soil, and climate of cultivation, as well as the harvesting and production processes, determine the material and symbolic qualities of coffee (Fridell 2007:112, Levi and Linton 2003). By virtue of their lower position in the GVC for coffee, farmers who are unable to translate consumer preferences into new cultivation and marketing strategies are neither equipped with the 
information necessary to exploit the extreme ups and downs of the market, nor can they independently take advantage of lucrative specialty markets. Although they possess the natural capital assets and are responsible for the activities that add value to coffee, producers tend to lack complimentary assets of human, social, and cultural capital to translate these qualities into added value (Bebbington 1999).

Coffee roasters, on the other hand, with their access to both product and market information, are privileged to choose how this information is communicated to consumers. Since certification systems are determined by adherence to regulations, inspections, and transparency, coffee producers necessarily provide roasters with complete product information regarding the material and symbolic qualities of coffee. Where "information equals power in the world coffee market," (Jaffee 2007:77), coffee roasters with access to information on product quality and market demand benefit from the majority of value-adding opportunities (Daviron and Ponte 2005). Their position in the GVC allows them to either express or obscure production information, depending on the potential for this information to add to or detract from value. Other hindrances, such as the time-sensitivity of roasting (Talbot 2002) versus the considerable shelf life of green pre-roasted coffee (Pendergrast 2000) and the prohibitive cost of shipping and licensing small amounts of coffee, prevent small-scale coffee growers from profiting on the roasting stages of production.

However, the ability to translate quality information into added-value comprises a primary barrier to entry for coffee producers, whose 
communication is constrained by what James Scott terms the "opaque" transparency of standardized language (1998:72), the most effective means of privileging those who have "mastered the universal linguistic code" necessary for international commodity trade. As with other internationally traded commodities, coffee has acquired a standard language to define, measure, and promote quality (Jaffee 2007, Daviron and Ponte 2005), largely foreign to producers who may have never tasted a brewed cup of their own coffee (Bacon et al. 2008). To participate more independently in the international commodity market and control value-added stages of production, coffee producers would need to learn to "break the code" of coffee quality (Scott 1998), communicating the symbolic and material qualities of their product and interpreting feedback they receive.

\section{Fair trade as a safety net or crutch}

Economists have criticized Fair Trade as a market-based development scheme for obscuring for producers the connection between supply and demand, creating irrational product value, and perpetuating oversupply. By positing fair trade as a "charitable act, making a statement about the obligation of 'haves' to 'have nots"' (Berndt 2007), economists claim that fair trade allows farmers to persist, even prosper, in coffee production despite the sometimes inhospitable growing conditions, consequently inferior product quality, and a generally unsustainable livelihood. Furthermore, by demanding cooperative organization of coffee producers, FLO certification begets the pooling of individuals' coffee product. Critics (Booth and Whetstone 2007, Pirotte et al. 
2006, Parrish et al. 2005) assert that in order for producers to develop the capacity to earn higher prices in specialty markets, they must be paid on the basis of individual production and according to the quality of their personal product. By paying individuals based on collective growing practices, fair trade disrupts the connection between demand for high quality and commensurate pricing.

If it has accomplished one stated goal, it is that Fair Trade provides coffee cooperatives with access to roasters at preferential prices. It does not appear to be effecting change in roasters' monopoly of the coffee quality information that becomes translated into added value. Nor does it look to be preparing farmers to assume control over value-adding stages of production. The market access approach to Fair Trade is insufficient in that it not only prolongs producer dependence on a commodity of declining terms of trade, but it also fails to address the prevailing system of "unequal exchange". In this way, an alternative trade organization structured in the manner of Fair Trade can both assist producers to increase their productivity and export proficiency while simultaneously prolonging their dependence on "products with poor future prospects" (LeClair 2002). Access to the market alone is not enough to offer commodity producers justice in a global economy when the producers' access to rents is restricted due to a persisting imbalance of power in the global value chain. Researchers note that the majority of value added continues to be extracted in consuming countries (Daviron and Ponte 2005:204). Similarly, Fitter and Kaplinsky (2001:16) note that the value added 
to coffee in specialty markets is not "filtering through to producers either at the farm level or at the national level," indicating that while Fair Trade may have altered the way consumers think about coffee, it has had little impact on either the way producers participate in the global market or the structure of unequal exchange.

As a result, more ATO-minded producers and roasters are looking at more direct trade relationships between producers and small roasters (Daviron and Ponte 2005, Luetchford 2007), "interstices" in the market created by fair trade (Renard 1999), where producer cooperatives can enter the market under more favorable conditions (Taylor 2005), with more stable prices, fewer intermediaries, and perhaps even access to better terms of credit (Tallontire 2000). As of late, it has been suggested that Fair Trade is more effective as a stepping stone to direct trade relationships with purchasers (Daviron and Ponte 2005) than a long-term solution to poverty. Researchers have noted that producers may establish international connections with purchasers via Fair Trade certification and pursue a trade relationship outside the Fair Trade system. Indeed, Fair Trade may in the near future encourage such decisions, as it is rumored that some long-term cooperatives may be determined to have been benefitting from fair trade for longer than their fair share. Producers in Luetchford's study expressed concerns that FLO may soon begin aging cooperatives out of the Fair Trade system in order to make more room for new members (2007:28). 
Direct trade relationships and relationship coffees offer potential solutions for some coffee growers to reclaim the qualities they add to coffee in production and trade by fostering market education and shortening the commodity chain. However, these solutions are only possible to market-savvy producers who are capable of identifying market opportunities, negotiating contracts, interpreting consumer feedback, and accurately valuing their own products. Were Fair Trade assisting producers to develop these skills, it could be said to be successful in its role as trustee to social and economic development. Unfortunately, researchers note that the bureaucracy of certification and auditing processes have only instructed producers in the requirements of certification while blinding them to consumer requirements and the workings of the market (Daviron and Ponte 2005:229).

\section{THEORETICAL VERSUS EXPERIENCED EFFECTS}

While the "old inequality" of unequal exchange was based on colonial control of the production process, the "new inequality" is based on developed countries' control of financial capital and flows of information" (Talbot 2002). In the GVC for conventional coffee, transnational coffee roasting corporations control the information regarding coffee quality, and, consequently, they are empowered to capture rents according the qualities they ascribe to the coffee product. In the case of certified products, however, the regulatory organization ultimately manages both market access and differentiation rents since they dictate the conditions of production linked to both symbolic and material quality (Renard 1999). To truly alter the GVC for coffee, coffee producers need 
feedback from consumers, greater technical knowledge of cultivation in order to match consumer preferences, and more authority and price information to independently negotiate contracts with roasters and retailers (Bunker 2001:139). As Rosenthal (2011) has noted, producers need equity not just in finances and a fair price, but also in skills, access, and decision-making. In this way, the skills developed as a result of the certification process can additionally stimulate producer incomes outside coffee economy (Daviron and Ponte 2005:186) by developing human and social capital and offering a positive, if indirect, outcome of Fair Trade certification.

In the vein of Li's call for more empirical examination of the "gaps between plans" and "facts on the ground" that result from the incongruence of technical solutions with externalized political-economic questions, this research project provides "in situ fieldwork" (Mayoux in Parrish et al. 2005) to reveal the outcomes of Fair Trade's technical solution to unequal trade and the poverty of coffee growers. Treating the Fair Trade mission statement as the development objective and progress requirements as the technical solution to achieve these goals, this research explores messy outcomes of Fair Trade certification.

Like Li, this examination does not seek to grant Fair Trade a pass/fail grade in achieving its development objectives, rather the objective of this research is to understand the unanticipated consequences that result from a development project framed in such a way that necessarily excludes from view irresolvable political and economic conditions. To enhance our understanding 
of the effect such exclusions may have on a trustee such as FLO's ability to assist a target population, this project will first flesh out the missing political and economic conditions of the producers it has certified. To highlight the refractory outcomes of the development scheme, this project will next reveal the reactions to Fair Trade from three producer communities, specifically addressing their expectations, both fulfilled and not, and the benefits and drawbacks they perceive to participation in Fair Trade. Finally, to evaluate the capacity of Fair Trade to assist producers in the specific area of upgrading in the GVC, this study examines knowledge in three producer communities of the value-adding language and tasks essential to collecting rents and upgrading into additional tasks beyond primary commodity production. 


\section{Chapter III: Research Design}

\section{METHODS}

The objective of this project is to evaluate Fair Trade certification as a market-based development scheme, examining the potential for Fair Trade to achieve the goals of the organization, as well as its progress in meeting the expectations of member producers. In this way, this project examines the following questions:

1. What are the development goals of various members of the fair trade network? Specifically, what are the goals held by certified producers and roasters?

2. How do these goals compare with the development goals proposed by the Fair Trade certifying agency?

3. How does fair trade certification work as a tool to meet the socioeconomic development goals of the certifying agency and the producers it certifies? In the specific case of economic development goals:

a. What is the relationship between the length of the commodity chain and the profits returned to producers?

- Is a shorter commodity chain associated with greater profit returns to producers?

b. What is the relationship between length of the commodity chain and knowledge of the international market for coffee? 
- Is a shorter commodity chain associated with greater market knowledge?

c. What is the relationship between knowledge of the international market for coffee and the profits returned to producers?

- Is greater market knowledge associated with greater profit returns to producers?

4. What impact do context-specific characteristics have on the progress towards the development goals held by producers, roasters, and the certifying agency?

To evaluate these questions, I employed a mixed methods approach to create comparative case studies of growers' cooperatives in three different communities, each currently practicing a different form of commercialization and each having some degree of experience as a Fair Trade certified cooperative (Bernard 2006, Driscoll et al. 2007). The comparative and multiscaled design of my study produced case studies that can be compared both at the national level, using the existing literature to highlight features unique to Guatemalan coffee cooperatives, as well as at the regional level, comparing the cases in this study to illustrate the range of experiences even when national level political-economic questions are shared. A mixed-methods approach, including participant observation, semi-structured interviews, and a survey, allowed for triangulation of data as well as more nuanced understanding of findings (Bernard 2006). Combining methods in this way 
illustrates, for example, not only the frequency of households without alternative income sources, but also the circumstances creating such as situation and the broader ramifications for the future of such households and their communities. Methods were coordinated using a sequential design, first conducting semi-structured interviews and using the resultant data for survey construction. Extensive interviewing prior to surveying allows for greater specificity of survey items, as well as more effective prompting when respondents misunderstand or misinterpret survey questions (Driscoll et al. 2007).

The research took place over a total of 18 months, commencing in 2007 with site visits to two of the three cooperatives, tours of the coffee processing facilities, and open-ended interviews regarding community life and opinions of Fair Trade. Research continued in 2008 with return site visits to two cooperatives and an initial visit to the third cooperative. During the return visits, I conducted open-ended interviews with cooperative members and leaders, discussing changes to the cooperative over the course of the past year, as well as the long-term research plan. For the initial visit to the third community, the president of the Grupo Organico arranged for my attendance at a meeting of the Comision de Comercializacion, in which were discussed opinions of Fair Trade, challenges to obtaining and maintaining certification, and the benefits and drawbacks identified by members, as well as the longterm research plan. 
After exploratory research in producer cooperatives, the research continued in 2009 with site visits to three coffee roasters in the US that were identified by one of the producer cooperatives as current or former purchasers of their Fair Trade certified coffee. In this phase, I conducted semi-structured interviews with representatives of the fair trade coffee roasters for their opinions on the meaning of "fair trade," experiences working with coffee growers, goals for the future of their partnership with producers, and perceptions of coffee quality.

The research continued with 15 months of continuous fieldwork from September 2009 to December 2010 among three different coffee growing cooperatives in the Boca Costa and nearby Western Highlands regions of Guatemala. These cooperatives have all sold at least one harvest within the last 10 years as FLO certified coffee, but have pursued three different trajectories for market participation in light of their Fair Trade experience. Fieldwork consisted of ongoing participant observation, as well as interviews conducted with 41 informants and a survey conducted with over 90 respondents in coffee growing cooperatives to better understand the variation in producer communities and experiences. These instruments were designed to gather information regarding producers' cultivation assets, income earning opportunities, input costs, production volumes, most troublesome coffee diseases, knowledge of the commodity chain for their coffee, and perceptions of coffee quality. In addition, interviews were conducted with representatives of other firms identified by coffee growers as supporting agencies or participants 
in the commodity chain for their coffee, including representatives of the purchasing cooperative, the national association of coffee growers, and various non-governmental organizations.

Interviews

I opted to use pseudonyms when I discuss the communities, growers, and purchasers. I wanted the interviewees and respondents to feel free to share their thoughts and opinions without being held accountable after I had left, and, in the case of the cooperatives, I did not want them to have to answer for any practices that might jeopardize their certification status.

\section{Coffee roasters}

Interviews were first conducted with Fair Trade certified roasters identified as current or former purchasers of coffee from one of the participating communities. These interviews occurred on-site at roasting facilities of the two smaller firms and at the administrative office of the larger firm. Interviews were recorded, when possible, with permission of interviewees. These roasters follow more closely the original model of alternative trade upon which the concept of fair trade was based, meaning they make frequent visits to the coffee growing cooperatives and offer additional support to community development above and beyond the requirements of FLO certification. Interviewees discussed their concept of fair trade, the challenges and rewards to working with small cooperatives in Guatemala, the similarities and differences of these Guatemalan cooperatives 
compared to other growers with whom they work, and their concept of coffee quality, including the quality demands they make of their suppliers.

In general, all informants appeared eager to share any information they felt might be useful to the research. Several informants applauded the approach of the study, specifically the objectives of describing alternative forms of fair trade and comparing their potential for realizing producers' development goals.

\section{Coffee growers}

Interviews of coffee producers were conducted primarily in respondents' homes, though in some cases respondents requested that interviews occur in a common-use building within the community. All interviews and surveys were conducted by a pair of researchers, one male and one female, both for enhanced accuracy in data recollection and to assure the comfort of respondents and their families. As it was anticipated that the majority of survey respondents would be male, additional effort was made to include female respondents in the semi-structured interview portion of data collection. In two instances, the female informant upon whom the interview was intended to focus repeatedly referred all questions to her husband, who had been busy in another room, requesting that he join the interview, until he eventually assumed the role of informant.

I conducted 22 interviews in community \#1 (10 women, 12 men), 11 interviews in community \#2 (6 women, 5 men), and 8 interviews in community \#3 (3 women, 5 men). Interviews were generally scheduled in advance, with a 
home visit early in the morning before family members left to work in their plots and a return appointment scheduled later in the day or, in some cases, in the following days. Interviewees were selected first according to a quota sample of community leaders, such as members of the junta directiva (board of directors) and supervisors of community development projects, followed by purposive sampling of women noted as "important" in casual conversation with community members. Purposive sampling is useful for instrument development when the type of information needed is identified but the entire pool of informants possessing this information is unknown (Bernard 2006). The combination of sampling methods ensured the representation men and women who are influential in defining the development goals of the communities.

Interviewees discussed their perception of fair trade, benefits and drawbacks to pursuing Fair Trade certification, experiences with development projects in the community, reasons for project failure and how they could be remedied, as well as their goals for the future of both their family and community.

Interviews were essential to a better understanding of the implications of Fair Trade certification for the producers and their families, as well as the language particular to discussions of coffee cultivation, including vocabulary terms that allowed me to ask more specific questions about the timing of coffee payments and the prices paid for different forms of labor. Additionally, these interviews helped establish rapport with interviewees and their families 
and opened doors to family and community events where discussions could be continued in a less formal setting, revealing more about the quotidian activities of life in a coffee growing community. Information from these interviews was later used to construct the survey implemented in all three communities.

Interviewees were generally eager to talk about their lives as coffee growers. Many requested that their comments be shared with those "in charge" of Fair Trade certification. Few topics, primarily related to community political struggles and adult education levels, elicited replies that appeared hesitant or guarded. On the contrary, interviewees seemed open and forthcoming with their thoughts and opinions. In fact, some information provided in the interviews, such as chemical use, sale of coffee to external buyers, and reallocation of social premiums, might compromise the organic and Fair Trade certification status of the cooperatives. For this reason, anonymity of respondents and their communities was guaranteed prior to interviews. When possible, interviews were recorded with permission of interviewees. Only in one instance, upon broaching the subject of the informant's illiteracy, did a respondent request to stop recording. Most respondents expressed appreciation at the interest taken in their opinions and experiences. Many requested that the researchers return for additional conversation at a later date. 


\section{Other participants}

In addition, I conducted semi-structured interviews with several other participants identified by cooperative members as involved in coffee production. For example, one interview addressed a representative of the Fair Trade certified coffee purchasing cooperative that had worked with all three communities in some capacity. In addition to the history and the function of this organization, this interviewee discussed the similarities and differences between the three cooperatives, primarily in their size, their vision of fair trade, and their manner of negotiating coffee prices. This interview yielded information necessary to better understand how the commodity chains of each cooperative are structured, how certification and processing costs are accrued and distributed across cooperative membership, and the characteristics that make one cooperative better suited for certification than another.

Another semi-structured interview addressed one representative of the national coffee growers association. Though not acquainted personally with any of the cooperatives, this informant was able to provide information regarding the types of training producers receive and additional supports available to small scale producer cooperatives. This interviewee provided copies of training modules that were later used in survey construction.

I conducted semi-structured interviews with three representatives of a local NGO that has worked with all three cooperatives. These interviews revealed the extent of political infighting in two of the three communities, viewed by these representatives as the biggest obstacle to successful 
community development. Representatives cautioned against volatile situations in the communities, such as the disputed presidential elections and struggles over control of the coffee roasting project in one community. These interviews also revealed changes in one community where cooperative members had just voted to individualize their holdings as well, concluding an ongoing struggle since the beginning of this research project in 2007. Representatives suggested several informants they considered to be impartial, as well as informants at both extremes of the individualization and presidential election debates. These discussions were key to treading sensitive topics of discussion in order to tactfully and sensitively obtain information vital to my study.

I conducted a semi-structured interview with the Fontierras-supplied technical assistant to one of the communities. This interviewee explained the structure of the Fondo de Tierras program, the terms of the loan, the official assessment of the potential for this community to repay their loans, and the characteristics that distinguish this community from other loan recipients. The interviewee further elucidated the challenges to successful cooperative management and the conditions that contribute to a community's likelihood for loan repayment.

In addition, I maintained ongoing informal interviews with representatives of development support agencies such as FUNDAP (Fundación para el Desarrollo - Foundation for Development), Fontierras, Catholic Relief Services, Pastoral de la Tierra, and local fair trade shopkeepers. Though these interviews were not conducted in a formal setting, 
they provided valuable insight into the political dynamics within the communities and the effect of local politics on the outcome of development projects.

\section{Participant observation}

Next, I began participant observation in coffee growing cooperatives in Guatemala, participating in coffee harvesting, processing, and distribution during the peak of the $2009-2010$ coffee harvest. I was able to pick coffee with a number of families in each community, where I learned about the entire coffee cultivation process, including planting coffee trees, pruning new coffee plants, renovating stretches of terrain, systematic coffee picking, and sorting beans before turning them in to the cooperative. This phase was crucial to the research, as I was able to compare planting and picking methods between communities, which reflect the familiarity of each grower with his or her work as a landowning coffee farmer. I learned about the diseases that most affect growers in each cooperative, as well as how minute differences in the location of a coffee plot can have significant effects on the difficulty of labor and the quality of the coffee product, which later became crucial elements of the survey. In addition, I learned about the ways in which family and hired labor are employed to minimize costs and maximize productivity. I worked in the nursery, where I learned about the inputs required to construct a nursery, the high level of maintenance required by coffee saplings, the vulnerability of plants to the elements, the process of grafting coffee varietals, and the importance of starting with reliable plants. I also worked in the coffee beneficio 
of each community, where beans are received, weighed, fermented, dried, and sorted. This experience granted me a better understanding of how delicate is the processing work done on-site. I gained the confidence of beneficio workers who granted me subsequent invitations to their home for more informal discussions of their life as coffee workers and the pressure they bear as caretakers of the community's primary source of income. Furthermore, as a result of time spent coffee picking and processing, I had the rare opportunity to accompany cooperative leaders on the annual delivery of coffee to the bodega in Escuintla. There I learned how coffee is sorted, graded, and stored prior to shipment to foreign purchasers, as well as the security risks and precautions taken during transport.

By participating in all activities of coffee production, I learned the vocabulary terms specific to Guatemala and to the communities as well. Extensive discussion of coffee cultivation allowed me to create a more accurate survey, using precise terms for processing activities, coffee plants at various stages of growth, microclimate-specific coffee diseases, coffee cherry characteristics, tools, and pruning techniques.

I participated in meetings of community development organizations, cooperative leaders meetings, as well as meetings of the junta directiva and the asamblea general (general assembly) in each community. In these meetings, I learned more about how decisions are made in each community, as well as the political dynamic in each community, which helped me to better navigate sensitive political topics and allowed me interview members at each 
end of the political spectrum without rousing suspicions of affiliation with one party over another.

\section{Survey}

Interview findings informed the survey (see Appendix), which was first piloted with instructors at a local Spanish school, then members of the Pastoral de la Tierra, and finally with a member of the junta directiva in one of the communities. The survey was comprised of the following eight sections: demographics, land holdings, employment, investment, production, commodity chain identification, knowledge of coffee quality, and comparison. The latter section asked growers questions such as whether they prefer a higher price or a stable price, if their production was better this year or last year, and if they were more concerned with improving the quality or quantity of their production. In piloting the survey, it was determined that two sections of the survey, those regarding commodity chain identification and coffee quality, would be particularly difficult for the majority of cooperative members to complete. The information contained in these sections was derived from training modules used by the national coffee growers association and interviews with coffee roasters in the US. These sections were intended to ask specific questions about coffee quality improvement practices, social premiums, international market values for coffee, and coffee disease prevention. However, it quickly became apparent that the majority of respondents struggled to answer these questions. In reaction to these survey items, producers appeared to become increasingly unconfident, apologizing for their lack of knowledge, doubting 
their ability to answer any subsequent survey items, losing interest in completing the survey, and ultimately regretting that they had not, they felt, been able to provide information of any value. To remedy this situation, questions in these sections were pared down to a smaller number of items which respondents were more likely able to answer. Furthermore, these knowledge-testing items were repositioned in the survey to occur between opinion-soliciting and personal cultivation technique items to which respondents could always provide a response.

The survey was then administered to over 90 residents in the three communities. In the largest community, participants were selected using a random sample. I constructed a map of all the homes in the community and used a random number generator to select homes for participation in the survey. In the remaining two communities a census was taken of all willing survey participants. I visited the selected homes in the morning, before residents were likely to have left for work in their plots. Upon the first visit, a return appointment was set, usually in the early evening just before dinner, so residents could anticipate completing the survey and make adjustments to their schedule accordingly. Each selected household received three opportunities to participate in the survey. After three incidents of no-response, new participants were selected by continuing the count of every $n$th home.

At each home, I asked to speak with the person who was most involved in coffee production. Most often the respondent identified was a male family member. In some cases, family members claimed that the male would not be 
present or able to participate in the survey, either because of work obligations outside the community or, in some situations, as a result of alcoholism. In such situations, an alternate respondent was permitted to answer, only in the event that they participated in coffee production and felt sufficiently confident to supply the requested information. Few surveys were discarded, primarily in cases where it was later determined that the respondent was a laborer, not responsible for any plot of land, or the respondent was unable to answer the majority of survey questions.

\section{SITE DESCRIPTION}

Guatemala's long history as a successful producer of reputable coffees provides, combined with the unique characteristics that result from the social upheaval and civil violence that peaked in the 1980s, make Guatemala an ideal location for the study. Furthermore, Guatemala has been underrepresented in the literature on Fair Trade impacts, which has focused primarily on coffee cooperatives in Costa Rica (Luetchford 2007, Ronchi 2002, Sick 1999), Mexico (Jaffee 2007, Calo and Wise 2005, Raynolds 2002), Nicaragua (Fisher 2007, Bacon 2005, Utting-Chamorro 2005), and, increasingly, African countries such as Tanzania (Pirotte et al. 2006, Parrish et al. 2005). In the few studies to investigate Fair Trade impacts in Guatemala, researchers have tended to focus on the politics of the fair trade movement. Arce (2009) documents internal political turmoil as a result of Fair Trade certification. Lyon directs attention to struggles for gender equity in practice of fair trade (2008) as well as tension between producer and consumer still 
evident in the fair trade system (2006). Absent from these studies is an account of net earnings of producers in a fair trade system or comparison of Fair Trade impacts with other market systems - conventional or non-certified fair trade.

By selecting three cooperatives all located within the same coffee growing region, I was able to control some variables such as environmental conditions, access to resources, and opportunities to receive external support for coffee production. Within this region, however, each community has a unique origin story that explains some fundamental differences in community demographics.

The cooperatives are located in small communities, ranging from 30 minutes to one hour and 30 minutes distance by bus from the nearest city. Communities sizes range from 32 families to 145 families. Each community has experience with Fair Trade certification, though each currently practices a different form of market participation. The first community, Bella Vista, sells Fair Trade certified coffee. This community has been Fair Trade certified for 10 years, though recent spikes in coffee prices have prompted $50 \%$ of the community to opt out of Fair Trade and instead sell through a conventional coffee cooperative. A second community, Alta Gracia, sells what has been termed "relationship" coffee. They sold Fair Trade certified coffee for three years until certification fees were imposed. They continue to sell coffee through a Fair Trade certified importer and fair trade roaster, though the cooperative itself is no longer certified. The third community, La Esperanza, 
has resumed selling their coffee conventionally, though they sold certified coffee for the 2009-2010 harvest under the designation of a "transitional" farm. Their contract was discontinued after one year because of the lack of compliance with Fair Trade regulations and terms of trade. Cooperative members in all three communities requested assistance in getting representation with Fair Trade certifying agencies and were anxious to share their particular story with coffee consumers.

A primary distinguishing characteristic of the cooperatives in this study is that, unlike the majority of cases studies available in the Fair Trade literature, these cooperatives are comprised of very small-scale producers, most families producing less than 1000 pounds of coffee in a year while the average producer in a Fair Trade certified cooperative in Guatemala produces around 2500 pounds of coffee in a year (Fair Trade USA N.d.). Whereas the majority of literature focuses on cooperatives that produce in excess of the volume that Fair Trade can assist them to sell, these producers are unable to produce sufficient quantities to fulfill their contract obligations. Additionally, in all three communities nearly $100 \%$ of residents participate in a growers' cooperative, so that the communities are often referred to using the cooperative name. These characteristics, in addition to each community's distinct Fair Trade experience, distinguish the cooperatives in this study from those typically represented in the Fair Trade literature. 


\section{Bella Vista: The Fair Trade certified community}

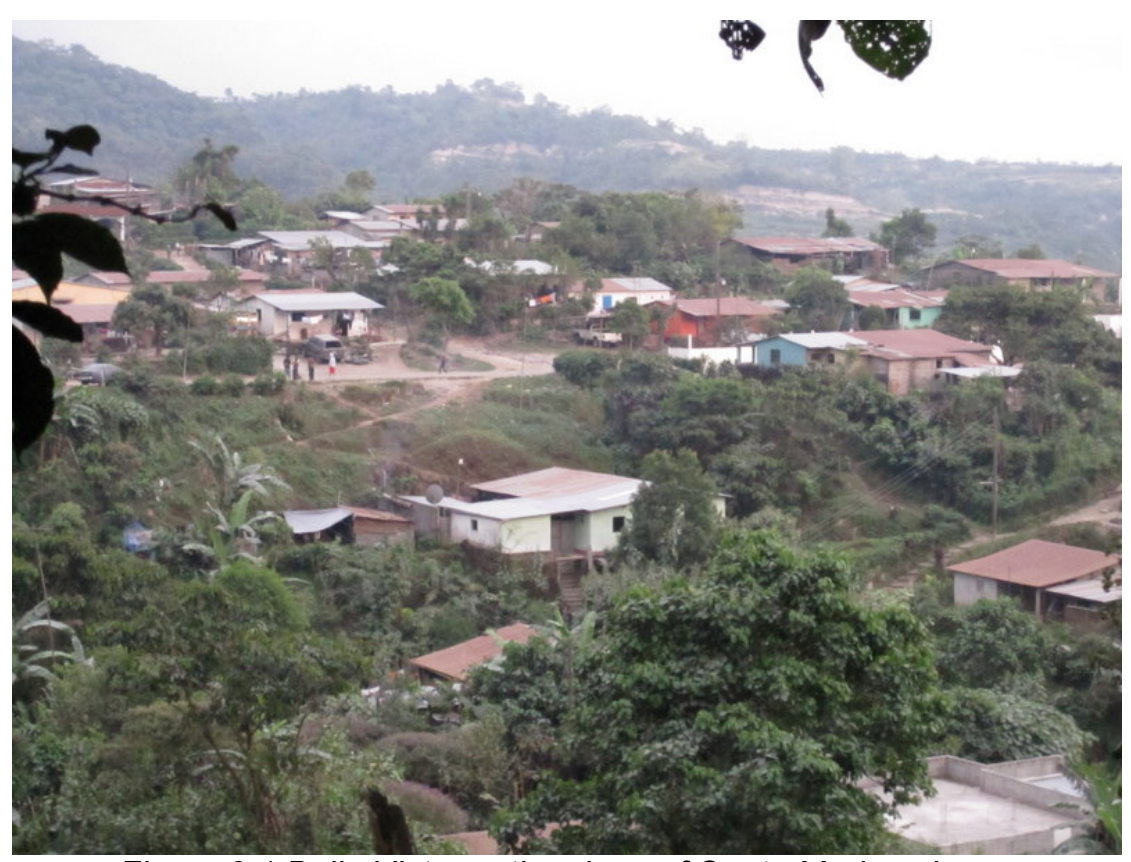

Figure 3.1 Bella Vista on the slope of Santa Maria volcano

This community was founded in 1976 after a group of finca workers, trained as catequistas (catechists) by Catholic missionaries, petitioned the church for help in establishing their own settlement. Exhausted by the labor demands of their respective proprietors, impoverished by paltry salaries, burdened by restrictions against church attendance and mandated work schedules, the workers pleaded with their visiting priest, a Spaniard, for help in raising funds to purchase a coffee finca of their own. After years of searching, all the while feigning hopelessness to allay the petitions of the workers, the priest acquired a donation from a German Catholic organization sufficient to purchase a finca in the same region as the catequistas lived, and there he established the basic infrastructure of a coffee farming community. The finca is comprised of 347 hectares, of which about half is available for cultivation, the other half consisting of protected forest. Each original resident received 
plots totaling 50 cuerdas for cultivation, to which was later added an additional 50 cuerda share of the unusable forest reserve. The priest arranged for construction of one house for each family, to be repaid at well below cost. In addition, the priest organized infrastructural development projects, which residents supported with volunteer labor, to construct a road with requisite bridges for leaving and entering town, a water tank, sewage, electricity, a primary school, coffee processing facilities, and a church.

The founding priest resided in Guatemala and made frequent visits to the community until the early 1980s when the nationwide civil violence threatened his safety. Residents of the community occasionally relate their experience of the civil violence, explaining that their unity initially helped them to survive. Elderly residents tell of their bewilderment and terror, contrary to their children's excitement and delight, upon first sighting a military helicopter pass through the mountains. Little is spoken of guerrilla involvement, though stories relate the unanimous stonewall response of residents who were questioned by militants as to guerrilla whereabouts.

The community is located in a valley on the side of the Santa Maria and Santiaguito volcanoes, the latter of which is still active and daily spews smoke and ash, frequently covering the community in a thin layer of grey dust. The volcanic ash is both a blessing and a curse, because it contributes to the welldrained soil ideal for coffee growing, but has also undermined all attempts at raising food for livestock. The community has access to fresh running water from sources in the mountainside both above and below. Three buses daily, 
one early and primarily for students and two for general use, provide transportation from the community to the nearest city, about one and a half hour drive from the community.

In addition to coffee, residents commonly cultivate pacaína (decorative palm), pacaya (date palm blossom), and some bananas. While pacaya and banana are grown primarily for household consumption and sale in local markets, pacaína is collected by an export purchaser who commissions a set amount from the community, distributed as allotments among residents. Unlike coffee, pacaína provides a year-round, though meager, source of income. A women's project raising chickens for sale both within the community and in neighboring farms has been successful enough to sustain itself, but has not provided a significant source of income. The community is also home to a women's roasting cooperative that purchases coffee from residents both within the community and from organic fincas in the surrounding area, roasts and packages the coffee, and delivers one-pound packages for sale in nearby cities. 


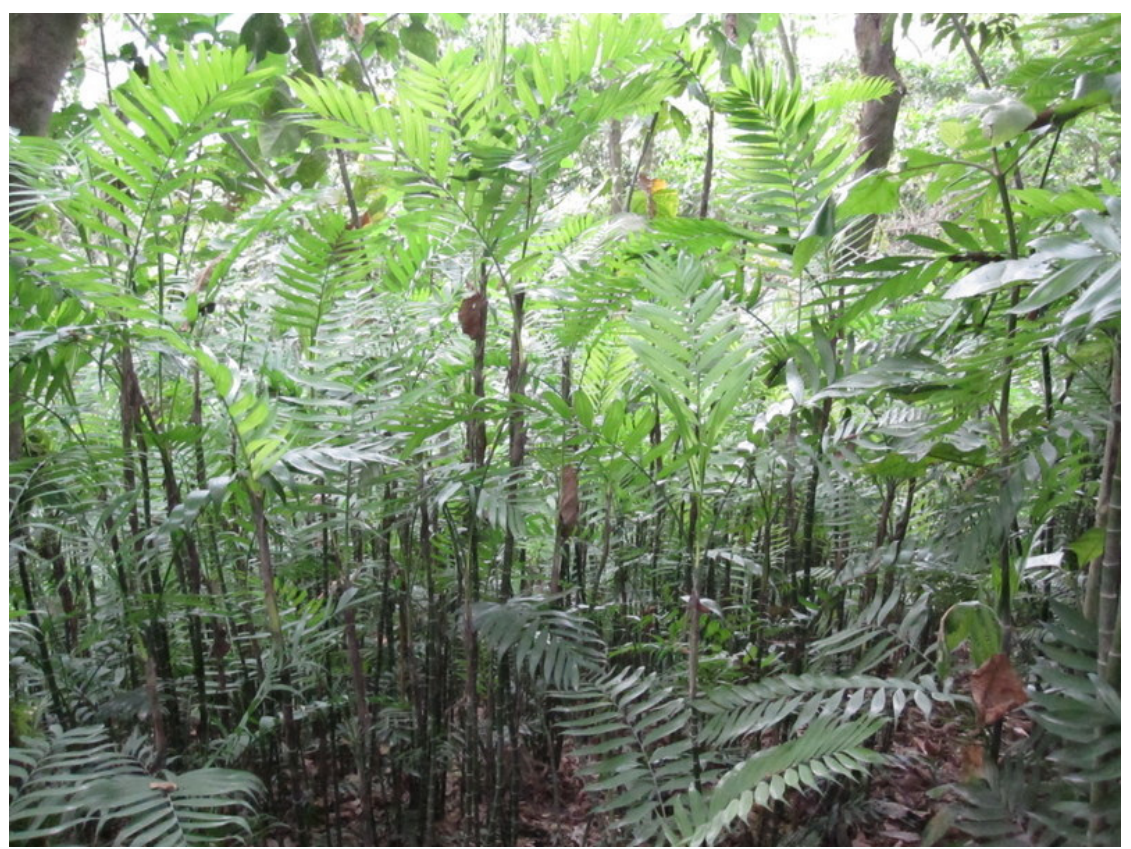

Figure 3.2 A plot of pacaína

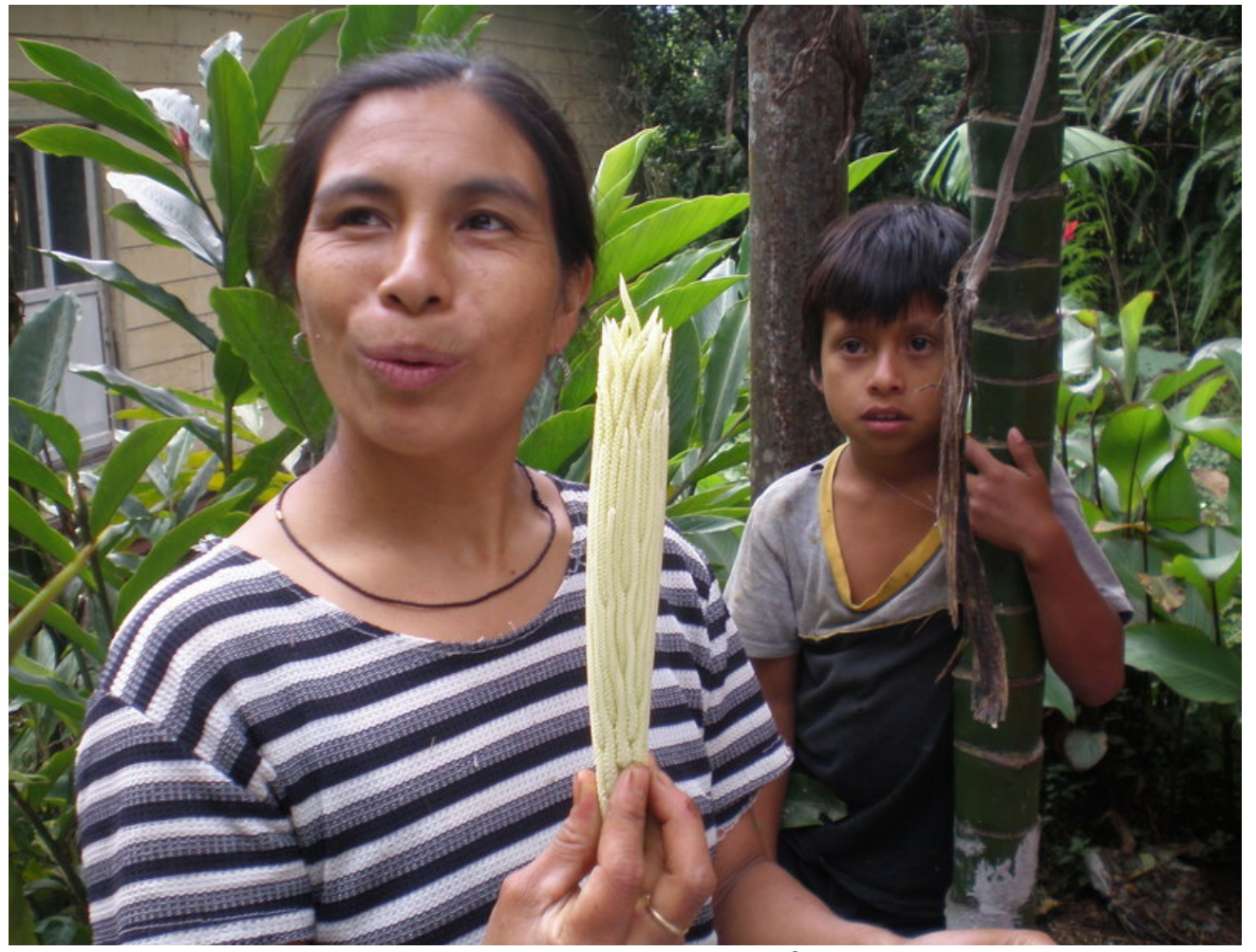

Figure 3.3 Pacaya, the edible blossom of the date palm tree 
The initial residents of this community belonged to one of 10 founding families, three of whom were mozos (laborers) of the purchased finca while the other seven gathered from fincas in the surrounding area. The heads of these families initiated a screening process to determine subsequent residents to admit into the community. The original settlement of 77 families has since grown to 145 families, approximately 1,050 people. The average household size of those participating in the survey was 6.8 persons. The average age of survey respondents was 48 years old, with 14 female participants of the 38 respondents. Residents primarily speak Spanish, the majority as a first language. Though a few residents may be heard speaking their native Kanjobal in passing, it is treated more as a novelty than a medium for extended communication. Similarly, some first generation residents may be seen dressed in traje, or traditional attire, but no women of the second generation were seen to be wearing traje during the extent of this researcher's time in the community.

Because of the pivotal role of the church in the founding of the community, all residents enthusiastically profess the Catholic faith. The church has provided the means of economic stability, land rights, community infrastructure, education, and, according to many women of the community, gender equality. The church provides women with opportunities to participate in activities outside the home, including as catequistas, ministras (ministers), members of the pastoral de la mujer (pastoral of women), the pastoral familiar (family pastoral, and the pastoral del niño (pastoral of children). In addition, 
women often refer to sermons in which the visiting priest expounds upon the importance of women's work in the home in securing the success of a family, reminding women that, though their duties are different from those of men, they are equally vital to the functioning of the household. Indeed, women in this community cite instances of husbands sharing in housework, childcare, and food preparation. Though machismo certainly exists in the community, as evidenced by the attrition of employees in the coffee roasting cooperative at their husbands' behest, many women claim that the greatest challenges they face are self-imposed: the perceived limitations of illiteracy and childcare obligations. Women have even, on occasion, been elected as members of the junta directiva, though they are more likely to decline the position than accept.

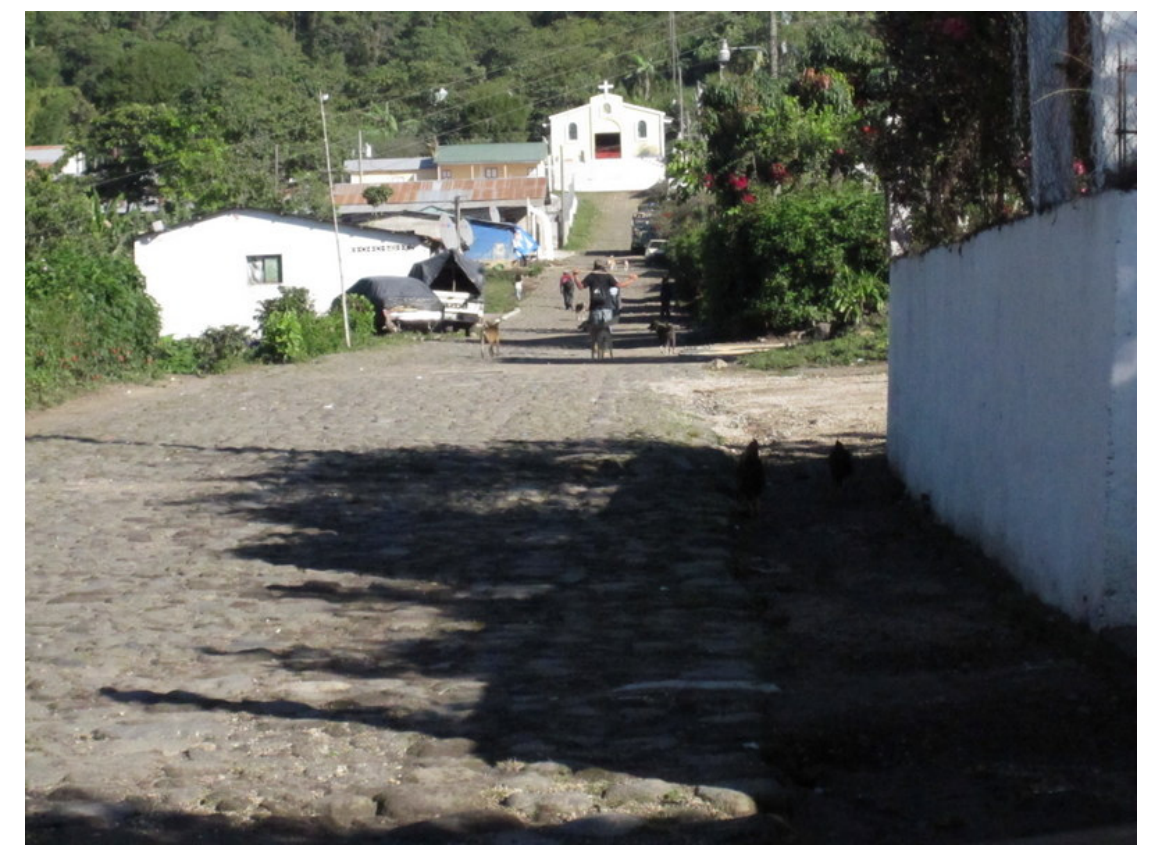

Figure 3.4 The main road in Bella Vista, culminating at the steps of the church

The community is governed by an elected body, the Cuadro Directivo (management), also known as the Consejo de Administración (Board of Directors), which is broken into constituent councils on education, agriculture, 
vigilance, and commercialization. Voting rights in all major elections are held only by the socios (cooperative members) of the community, typically the male heads of family, though widows automatically assume the role of socia upon death of a spouse. Single women and other residents may choose to be made socio, which involves payment of a registration fee. Socios are required to attend all meetings, which may take place as often as weekly, or else pay a fine for each absence.

While residents of the community are entitled to use assigned plots of land, the land is in fact titled in the name of the Catholic church. Residents must follow a moral code written upon founding of the community, which includes as a primary provision observance of the Catholic faith, as well as prohibitions on theft, gossip, contraceptive use, and adultery. Failure to observe the moral code warrants a trial before the Alcalde Auxiliar (Auxiliary Council) and, if found guilty, possible sentencing of a warning, mandatory community service, such as working in the coffee patio or clearing trails, or, in extreme cases, revocation of property rights. Two extreme cases, involving theft and drug cultivation, have resulted in ejection of residents from the cooperative. Though residents do not fully possess property rights, they are permitted to use land titles as collateral in order to obtain loans. Because the community property is held collectively, the coffee produced is considered a community resource. Residents are required to turn their contribution of coffee harvest, collected from their assigned plots, in to one of the two coffee 
cooperatives. Failure to do so is tantamount to theft, though an ambiguous form, more disdained than formally enforced.

Until recently, community members comprised a single coffee cooperative, initially producing and selling in a conventional manner in the national market. At the recommendation of the priest succeeding the community benefactor, the community converted to organic production and received certification in 2000 to sell organic and Fair Trade coffee. However, rising conventional prices, difficulty of labor requirements, and dissatisfaction with organic cultivation techniques prompted a faction of community members to propose a return to conventional methods. In 2007, after months of debate, the Cuadro Directivo assented to a community vote on how residents would prefer to cultivate. They provided a list of requirements to maintain organic and Fair Trade certification, and residents were given one week to discuss the matter with their family before submitting their ballot. Voting results were split, with 52 socios electing to remain in the Grupo Organico and 51 socios opting to join the Grupo Convencional, the Conventional Group. 


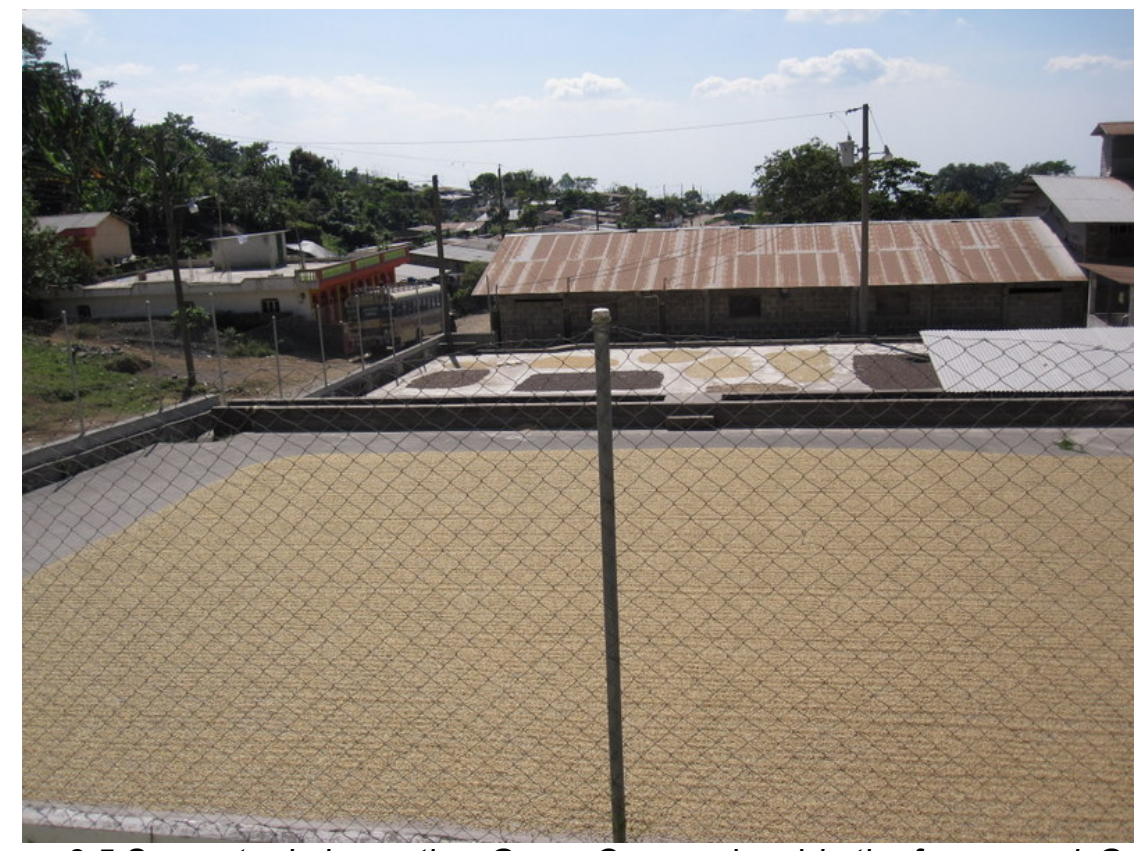

Figure 3.5 Separate drying patios: Grupo Convencional in the foreground, Grupo Organico in the background

Thus, though residents continue to work and live in a single cooperative, it is now comprised of two different production groups with their own junta directiva, coffee purchaser, beneficio staff, and even the drying patio has been divided into an organic tier and a conventional tier. Members of the Grupo Convencional have been gradually shifting back to the Grupo Organico, most often citing the superior "organization" of the Grupo Organico as their primary motivation. At the end of the 2009-2010 harvest, the official count was 59 socios in the Grupo Organico to 51 in the Grupo Convencional. The cooperative split briefly disrupted the coffee volume presented to the purchasing cooperative, which had to combine Grupo Organico coffee with coffee from another cooperative in order to fill a shipping container. Production has since recovered, and the Grupo Organico delivered 150 quintales (100pound sacks) of coffee from the 2009-2010 harvest to the Trans Café bodega in Escuintla, effectively filling their own shipping container. The Grupo 
Convencional produced slightly less, delivering a reported 125 quintales to their bodega in Coatepeque.

Alta Gracia: The "relationship coffee" community

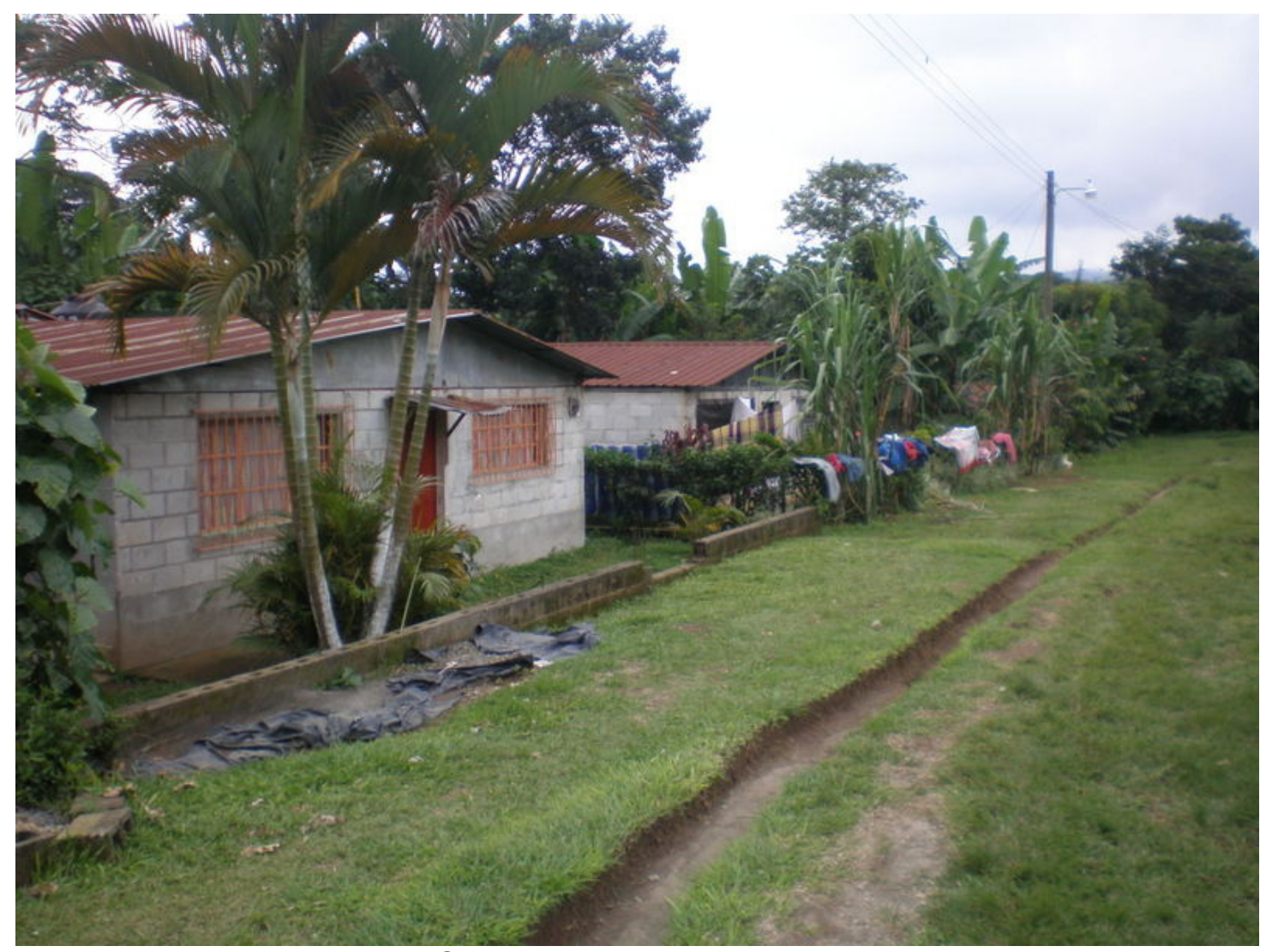

Figure 3.6 Alta Gracia: side-by-side block constructed homes

This community was created in 1998, after the signing of the Peace Accords marked the official end to the civil violence that had plagued the country for decades. The 40 founding residents of this community are excombatants with the ORPA (Organización Revolucionario del Pueblo en Armas - Revolutionary Organization of the People in Arms) who had been living in exile, primarily in Southern Mexico, during the final years of the civil violence. They entered the conflict in several cohorts, some as young as 14 when they joined, and some passing as many as 36 years in active service. All 
original residents of the community were familiar with one another in some capacity, some more intimately than others, prior to settling the community. Residents occupied a variety of positions in ORPA, including generals and communications specialists, and many outside observers, such as coffee roasters and NGOs, attribute the ongoing political infighting to residual effects of the civil violence.

In addition to encouraging exiled Guatemalans to return to their country, the Peace Accords of 1996 included a provision granting loans to help resettled populations rebuild their lives. The Fondo de Tierras, or Fontierras, program made loans available for investment in land and small businesses. After searching for an available plot of land, the residents found their current location, a former coffee plantation, abandoned and overgrown, empty with the exception of the former finca owner's home. All 35 original settling families shared the space of the Casa Grande until other arrangements could be made. Eventually, the community attracted the attention of international support groups, such as the Red Cross, who donated materials and labor to help build the community. As a result, there is a planned community feel to the settlement, which is comprised of two main streets and one cross street, with identical cinderblock houses set side-by-side lining both sides of the streets. 


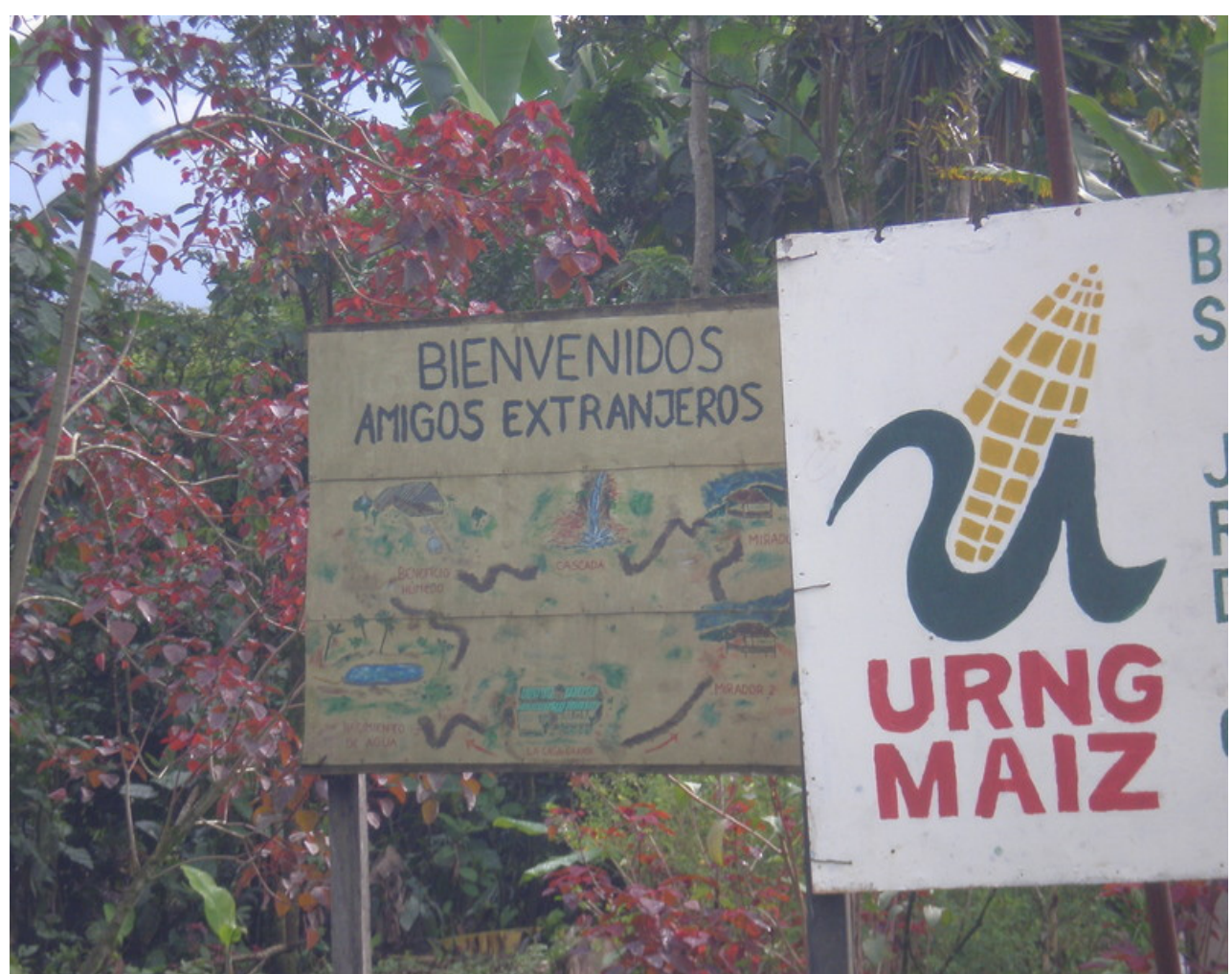

Figure 3.7 Entrance to Alta Gracia: signs demonstrate their openness to visitors ("welcome foreign friends") as well as their political affiliation (URNG is an umbrella organization comprised of ORPA and three other leftist political groups)

The community currently consists of 32 families and about 180 people. The average household size of participants in the survey was 5.2 persons. The average age of survey respondents was 46.5 with 2 female participants of the 24 respondents. Located alongside a well-traveled rural highway and only a 20 minute drive from the nearest city, the community is accessible by bus, pickup, and taxi. The finca is comprised of 500 hectares, of which about $65 \%$ is dedicated to coffee production. Residents initially cultivated bananas in addition to coffee, though disease has overtaken the majority of banana trees and little effort has been made to revive this crop. Ecotourism now provides the secondary source of community income, with earnings reinvested in development projects such as road improvement and potable water facilities. 
Donations from both their partner roaster and a local NGO financed a small coffee roasting project in the community, allowing residents to toast, package, and sell pounds of coffee to visitors within the community and tourists in nearby cities. Despite sufficient demand, political infighting and inadequate coffee harvests have halted coffee roasting indefinitely. The community has also received donations for projects in vermiculture, banana bread production, organic gardening, and chickens.

The effect of the war on identity, both in terms of indigeneity and gender, was a recurring topic of discussion amongst women in the community. Residents originate from a variety of departments, language groups, and climates, and backgrounds. Some are accustomed to the heat and humidity of their current home while others are still adjusting to the ever-present mosquito. Some residents speak Spanish as a second language, but few share a mother tongue. Those who once spoke Mam, Kaqchikel, or Quiche now rarely utter the language, even to each other, nor does the majority of women dress in traditional garb. The abandonment or embrace of traditional identity has become a point of contention among some women, with accusations of discrimination against those who choose to express their traditional identity.

Gender roles within the community provide another source of conflict amongst residents. Several women explained that, while in battle, men and women shared in cooking and cleaning duties, each washing their own clothes and dishes, taking turns preparing meals for the entire crew. But upon settling into a community, several women complained that men and women alike had 
"forgotten" how to share in domestic chores, with men instead resuming machista habits of ordering their wives to wash and iron their clothes and demanding dinner at a specified time. Women participate in the junta directiva, though typically serving the role of vocal, only once elected as secretary. The ecotourism project, a lucrative source of development funds for the community, has thus far been administered and staffed entirely by women, but the newly elected junta is interested in becoming more involved with this income-generating resource for engaging NGO support. On the other hand, the new junta has pledged to train women to operate the tostaduría equipment and hand administrative authority over to an elected female leader. The tostaduría project was originally intended to be administered by women of the community, but the cooperative president had assumed sole control over the facilities.

Further dividing residents is their experience in coffee cultivation prior to resettlement. Some residents arrived at the finca with decades of experience working in coffee as day laborers, while some had never so much as picked a grain of coffee. Despite their differences, one common factor uniting the residents is the process of learning to be landowners, responsible for all stages of production and, in many cases, financially dependent upon the outcome of each year's harvest.

Upon accepting support from Fontierras, residents agreed to start repaying the funds, with interest, after a 5-year grace period. During this grace period they also received the technical support of an agronomist, intended to 
not only advise in renovating the overgrown finca, but also instruct residents in the basics of coffee cultivation. Though the grace period ended in 2003 , the community has yet to make a single payment toward either the principle or the interest of their loan. Production levels are steadily declining, and each year the cooperative struggles to fill their contract with the partner roaster in the US, continually falling increasingly short of their goal. In an effort to improve production volumes, the community began receiving assistance from Catholic Relief Services in 2009, including a resident agronomist and donations for construction of a nursery and organic fertilizer production.

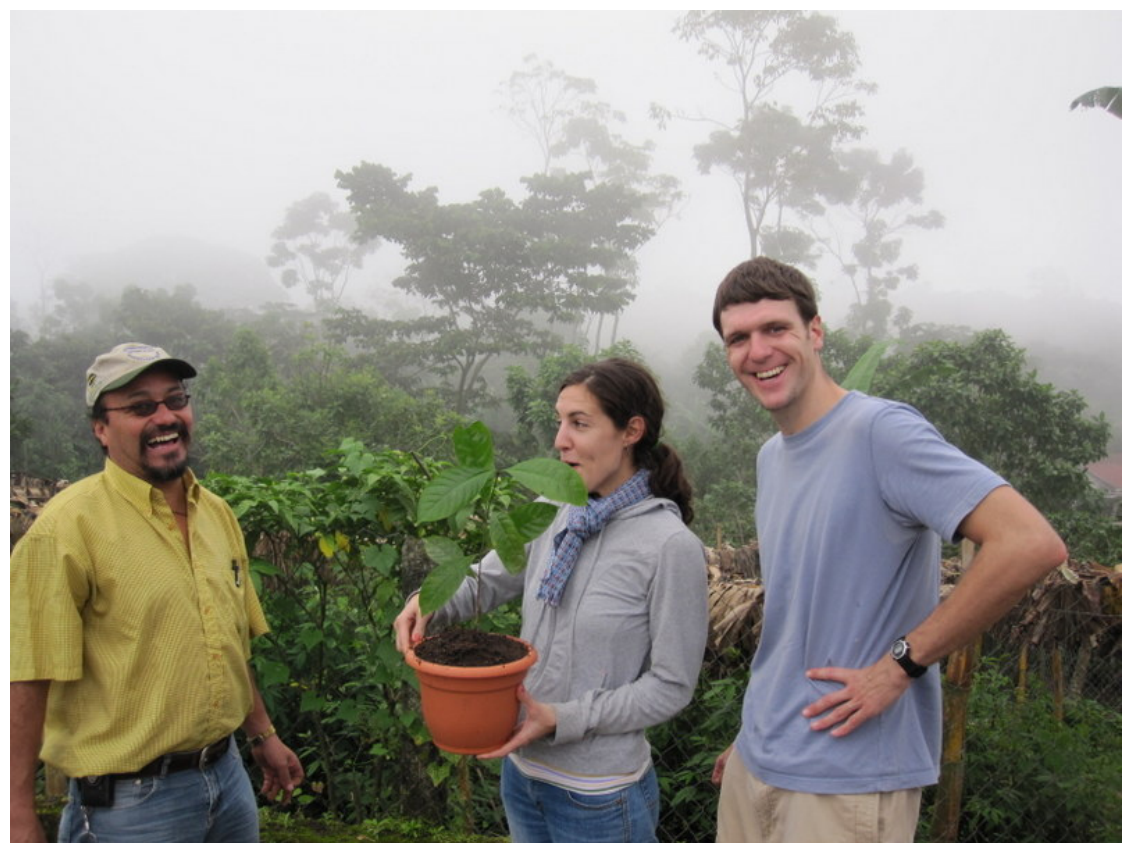

Figure 3.8 Agent of development: the author and husband discussing coffee varietals (a rare Maragogype featured here) with the resident Catholic Relief Services (CRS) representative

Since the farm had been abandoned several years prior to resettlement, and the residents had little expendable income to invest in chemical inputs, the finca was a natural candidate for organic certification. With assistance from visiting agronomists, the community obtained organic 
and Fair Trade certification in 2000 and began selling coffee through Fair Trade channels. The growing popularity of the Fair Trade mission, combined with the compelling story and political tone of the community settlement, attracted the attention of international aid organizations who have donated labor, supplies, and counsel on organic farming practices. In addition, these organizations began inviting community leaders to the United States and Europe to give lectures on their experiences in the civil violence and their struggles to recover their lives. The elected president of the coffee commercialization took advantage of these opportunities to seek a more direct Fair Trade purchaser for the cooperative. Eventually this led to a relationship between the community, their partner roaster, and their Fair Trade certified importer in the United States.

The community continued to sell coffee to their partner purchaser and a few other small roasters as Fair Trade certified until 2007 when the imposition of inspection fees associated with the establishment of FLO-Cert Ltd., concurrent with the devastation of Hurricane Stan, prevented the community from renewing their certification. Their partner roaster agreed that, given their small volume of production, the flat-rate certification fees did not make financial sense for the cooperative. The roaster and cooperative have maintained their relationship, still marketing the coffee as fair trade, but the fair trade guarantee is made on basis of their personal knowledge of the working conditions of the community rather than the authorization of FLO-Cert inspectors. As a result, at the time of this research, Alta Gracia's coffee was 
not FLO-certified, nor was their roaster, though the coffee importer was FLOcertified. Alta Gracia's coffee was organic certified at the start of this research, though at the end of fieldwork, their organic status was in jeopardy.

The majority of community residents participate in the cooperative, with 27 of the 32 resident families contributing the bulk of their harvest. The remaining five families opted to sell their coffee independently, usually transporting coffee themselves to a nearby city. Economic necessity, or the inability to await delayed coffee payments, and lack of transparency in cooperative administration are cited as their primary reasons to remain independent. However, political upheaval within the community has resulted in shifting alliances and uncertainty for the future of the cooperative.

Community leadership has been characterized by faction-swapping of power, but the tension escalated in 2010 with a hostile overthrow and ouster of the only President of Commercialization ever elected to the position, as well as one of his supporters, the Vice President of Commercialization. The newly elected leadership expresses a desire to maintain contracts with their Fair Trade certified roaster and importer, though as the international coffee prices rise, the new administration hints that visiting suitors have offered higher onetime prices for the $2010-2011$ coffee harvest. In the wake of this political turmoil, and in light of ill-prepared new leadership, the community's certified organic status has been compromised. Furthermore, the ejection of two community leaders and the flight of three additional families in their support has significantly diminished the already-meager production volume of the 
cooperative, hence their ability to fill the purchaser's contract. No longer producing or selling for the Alta Gracia cooperative, the seceding group has joined forces with neighboring cooperatives, pooling their coffee to create an amount greater than that produced by Alta Gracia. This new alliance, headed by the community's primary liaison with the purchaser, as well as the original cooperative both intend to sell coffee through the Fair Trade importer and roaster, though the latter is uncertain how to proceed.

\section{La Esperanza: The no-longer Fair Trade community}

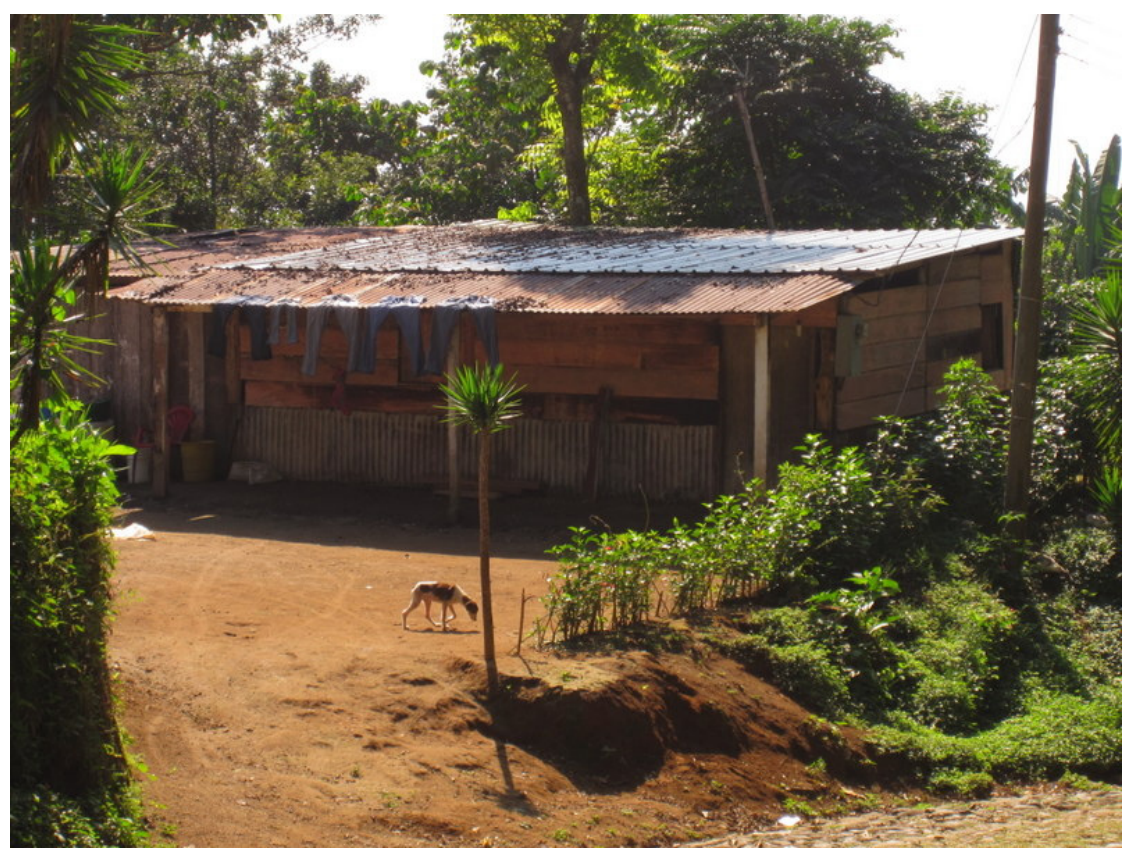

Figure 3.9 La Esperanza: wood plank and corrugated steel type construction is typical of about 25 families in the community

The members of this cooperative have lived and worked together as a community for generations. The eldest residents were born and raised on the same land they now watch their children and grandchildren and even greatgrandchildren cultivate. Though the land may not have changed significantly over the course of their lifetime, proprietorship changed dramatically in 2004 
when residents won the right to purchase and assume control of their decades-old home.

When coffee prices crashed in the late 1990s, the former proprietor, like many other finca owners in Central America, cut his losses by abandoning the farm. In doing so, he saved on the cost of labor by choosing not to harvest a crop of little commercial value. At the same time, he also left the residents, his former employees, without work, income, food, or electricity. The former owner eventually declared bankruptcy, defaulted on his loans, and the property was repossessed by the bank, leaving the residents who remained on the land now classified as squatters. Those who stayed behind scraped by on the little resources available to them, primarily foraging for edible plants, while those who were able left the community in search of work. For 18 months community members endured these conditions until one resident, frustrated by the cost of living in the city and anxious to return to his family, began rallying support of his relatives and former neighbors to reoccupy the finca, return it to a productive state, and manage commercialization collectively. These residents returned to the community in 2002 and initiated the process to claim the rights to live and work the finca for themselves. After months of legal battles, and with legal counsel of two labor unions, the community in its current form was founded in 2004 when residents first won the right to occupy the land and later received a loan from Fontierras on the condition that they not only pay the market value of the finca but also repay the debts owed by the former land owner. 
The community consists of 40 families and around 250 residents. The average household size of survey respondents was 7 persons. The average age of respondents was 44.8 years old, with 7 female participants out of 27 respondents. The primary source of income in the community is macadamia nut harvesting, followed by coffee cultivation, water purification and distribution, and, lastly, ecotourism. Some on-site processing of macadamia into salted or candied nuts and off-site coffee roasting allow the community to sell a small amount of processed products both within the community, almost exclusively to visiting tourists, and in nearby cities. Since its founding as a cooperative, the community has also received support for projects in biodiesel and biomethane production, bamboo furniture construction, a dairy, and chicken- and pig-raising, though none of these projects were maintained independent of donations.

The community is governed by a junta directiva, democratically elected each year. Since the founding of the community, the same president has been re-elected annually. This figurehead was primed by the former finca owner as an understudy to assume management responsibility in the proprietor's absence. It was only natural, then, that he assume authority over the administration of the cooperative. In 2009, however, after accusations of mishandling funds and excessive travel outside the cooperative, a new president was elected. As the initiator of the back-to-the-finca movement, he is trusted and viewed as more invested in the community than his predecessor. $\mathrm{He}$ is, however, a more timid leader, less charismatic, and illiterate, leaving 
doubt in the minds of other junta members as to his ability to administer the financial affairs of the community.

Women have not held office in the junta, though community leaders refer to the presence of a women's junta as evidence of gender equality within the community. Heads of family, including seven landowning widowed women, or their representatives, are granted voting rights in the asamblea general. In addition to the elected members of the junta, representatives from each of the income-earning projects, including one female manager of ecotourism, report their activities to the asamblea so that residents may democratically determine how to use community resources such as project earnings and land.

In general, women in the community stated that gender relations were better than in the past when living under a finca manager, since women are now able to work and participate in income-earning activities in the community. In the case of the few women who had left to work or attend school outside the community, however, the potential for gender equality witnessed in other communities highlighted the progress yet to be made in allowing women to hold the same positions as men, to be managers of their own projects, and to contribute to the wellbeing of their families. Considering the importance women place on supporting their families as mother, wife, and daughter in determining the success of a woman, as well as the significance of representation in decision-making, the spate of unmarried mothers coupled with the isolation of women to their own sporadically-functioning junta 
suggests much room for improvement in position of women within the community.

The farm was originally worked as a collective, with residents receiving a small but vital paycheck every 15 days in addition to meager per-pound compensation for the coffee and macadamia they collected from their assigned work areas. But from the beginning a few families had outspokenly supported individualization of landholdings, for several reasons. First, they felt that, under the system of assigning to each family responsibility for a portion of the land, the work was unevenly distributed; some plots were easier or more difficult to work, depending on the pitch of the hillside, the distance of the plot, or the height of the trees. Residents were found to shirk their duties in the more difficult areas, hiding from the overseer, leaving their plots unmanaged, and heading to work in less treacherous areas. Second, they felt that this affected overall productivity of the community, diminishing the coffee harvest and inflating the community investment in paid labor to supplement the work of residents. Third, there was disagreement over how to best cultivate coffee, with some preferring the sovereignty to apply chemical fertilizer if desired. Finally, they wanted the right to sell portions of their terrain or offer the mortgage as collateral for loans. Furthermore, residents felt misled and uninformed about the financial administration of the community. The debate came to a head when the five-year grace period for the Fontierras loan ended and the community was finally required to start repaying their debts. The residents had accepted minimal monthly paychecks from the cooperative with 
the understanding that the difference was being set aside for loan payments. However, they were ultimately told that no funds had been set aside for repayment; the money had been reinvested in community projects.

As a result, in 2009, the community voted to individualize land holdings, initiating an ongoing process of surveying and demarcating plots. Each family will ultimately receive 55 cuerdas, the majority of which is arable land with an additional one cuerda intended for new home construction, a major priority in the community, where about half of the residents still live in wood plank constructions rather than proper cinderblock casas. A lottery system determined the distribution of plots, with each family receiving a portion of nearby productive land and a portion in the more distant, less productive terrain. Residents will now receive greater price per-pound for their macadamia and coffee harvests, but each family will be required to make an individual payment towards the Fontierras debt. At the time of this investigation, the transition was not fully complete, with some residents still receiving collective paychecks while others had fully converted to individual earnings.

Though coffee is second to macadamia in terms of financial significance, its importance is bolstered by its function as a beacon for international attention to the development needs of the community, both drawing visitors to the community and garnering invites for community representatives to attend international conferences and workshops. The cooperative began by selling its coffee to intermediaries who approached the 
finca as suitors for the coffee harvest. Rather than pursue Fair Trade certification, the presidents of both the cooperative and coffee commercialization agreed that a better price could be reached by establishing direct trade with a buyer in the United States or Europe. Despite their resistance to certification, in 2008 the community received a donation from a Swedish NGO to finance both organic and Fair Trade certification of coffee and macadamia cultivation. As a result, the cooperative initiated the processes of obtaining organic and Fair Trade certification.

Organic status was conferred in 2008 , and in that year the cooperative established a relationship with the local Fair Trade purchasing cooperative. For one year their coffee was sold as Fair Trade under "transitional" status, but certification was never finalized. Both the purchasing cooperative and the producer cooperative sought to terminate the relationship, the former citing noncompliance with certification requirements and lack of commitment to the Fair Trade terms, while the latter objected to the discounts made for transportation, processing, storage, and administration. The community has reverted to selling coffee in the national market, with no desire to resume the Fair Trade certification process. 
Table 3.1 Comparison of communities - demographic and production indicators

\begin{tabular}{|c|c|c|c|c|}
\hline & $\begin{array}{l}\text { Bella Vista - } \\
\text { Grupo } \\
\text { Organico }\end{array}$ & $\begin{array}{l}\text { Bella Vista - } \\
\text { Grupo } \\
\text { Convencional }\end{array}$ & Alta Gracia & $\begin{array}{l}\text { La } \\
\text { Esperanza }\end{array}$ \\
\hline Membership & 59 families & 51 & 27 & 40 \\
\hline Experience $^{1}$ & 25 years & 31.5 & 12 & 27 \\
\hline Attended school & $82 \%$ & $50 \%$ & $83 \%$ & $63 \%$ \\
\hline Years of school (if attended) ${ }^{1}$ & 6 years & 3 & 9 & 3 \\
\hline Children $^{1}$ & 5 & 7 & 3 & 5 \\
\hline $\begin{array}{l}\text { Household members who work } \\
\text { in coffee }{ }^{1}\end{array}$ & 3 & 3.5 & 2 & 4 \\
\hline Employment outside coffee & $50 \%$ & $17 \%$ & $50 \%$ & $26 \%$ \\
\hline Landholdings in coffee $^{1}$ & 18 cuerdas & 15 & 28 & 47 \\
\hline Distance to furthest plot ${ }^{2}$ & 60 minutes & 53 & 28 & 49 \\
\hline Coffee grown in furthest plot & $66 \%$ & $50 \%$ & $88 \%$ & $100 \%$ \\
\hline Age of oldest plant ${ }^{1}$ & 20 years & 22 & 40 & 40 \\
\hline Trees planted $^{3}$ & $88 \%$ & $78 \%$ & $88 \%$ & $92 \%$ \\
\hline Number of trees (if planted) ${ }^{13}$ & 150 & 175 & 1400 & 950 \\
\hline Cost of trees (if planted) ${ }^{13}$ & OQ & $350 Q$ & OQ & OQ \\
\hline Applied fertilizer ${ }^{3}$ & $75 \%$ & $61 \%$ & $92 \%$ & $74 \%$ \\
\hline Cost of fertilizer (if applied) ${ }^{13}$ & $200 Q$ & $222.50 Q$ & $0 Q$ & OQ \\
\hline Hired labor $^{3}$ & $69 \%$ & $61 \%$ & $83 \%$ & $56 \%$ \\
\hline Cost of labor (if hired) ${ }^{13}$ & $1500 Q$ & $1500 Q$ & $2500 Q$ & $4000 Q$ \\
\hline Coffee produced by individuals ${ }^{3}$ & 9 quintales & 9.8 & 6 & 8 \\
\hline Coffee produced per hectare $^{1}$ & 7.57 quintales & 13 & 4.87 & unknown \\
\hline Sold outside ${ }^{3}$ & $19 \%$ & $18 \%$ & $75 \%$ & $4 \%$ \\
\hline Amount sold (if sold outside) ${ }^{3}$ & 1 quintal & 4 & 4 & 0 \\
\hline Price received by farmer ${ }^{3}$ & $938 Q(\$ 1.20)$ & $605 Q(\$ .76)$ & $\begin{array}{l}843 \mathrm{Q} \\
(\$ 1.08)\end{array}$ & $\begin{array}{l}502 Q \\
(\$ .64)\end{array}$ \\
\hline Price received by cooperative ${ }^{3}$ & $\$ 2.13$ & $\$ 1.09$ & $\$ 2.00$ & unknown \\
\hline Coffee produced by coop ${ }^{3}$ & $\sim 400$ & $\sim 350$ & $\sim 90$ & $\sim 300$ \\
\hline $\begin{array}{l}\text { Coffee produced by coop in a } \\
\text { good year }\end{array}$ & 400 quintales & unknown & 275 & 600 \\
\hline $\begin{array}{l}\text { Quality rated more important } \\
\text { than quantity }\end{array}$ & $75 \%$ & $43 \%$ & $60 \%$ & $77 \%$ \\
\hline $\begin{array}{l}\text { Fixed price rated more } \\
\text { important than variable price }\end{array}$ & $53 \%$ & $56 \%$ & $70 \%$ & $41 \%$ \\
\hline
\end{tabular}




\section{Chapter IV: Commodity Chains Compared}

Don Cristóbal:

Everything depends on the volume of coffee.

Don Ramón:

When there's enough coffee, it [the price] is cheap for us. When it's little coffee, the price goes up on us. It's backwards.

Don Cristóbal:

The costs, when it's little coffee, we lose a lot. Where there's a good quantity of coffee, then the prices go down.

Though distinct in their backgrounds as coffee growers, experiences living and working together, employment opportunities, and goals for the future, one characteristic uniting these cooperatives is their status as new landholders, deciding for the first time how to produce and market their own coffee harvest in order to receive the best possible profits. In a significant break from their past, these coffee growers are no longer paid by the day to clear weeds or paid by the basket to pick coffee, but they spend their own time, and oftentimes their own money, to care for their own land. They are no longer following work orders but organizing their own work schedules. Unlike day laborers who are hired by the job, with little investment in the final outcome of the coffee product, these producers' annual income hinges upon good growing practices, careful harvesting, and reinvestment to increase future production volumes. For the first time, these growers are responsible for the entire production process, from purchasing seedlings to fertilizing plants to picking their harvest to signing a purchase contract.

Fair trade and organic certification were presented to these communities as a means of providing financial security in a notoriously 
insecure market. Both Fair Trade and organic certification carried price "premiums", or additional per-pound compensation for the careful labor practices required for certification. Therefore, to the ears of coffee growers, the terms of trade accompanying either type of certification translated into mercados preferidos, or "preferred markets", where their coffee product would be worth more than in the conventional national market. In foreign markets, they were told, purchasers paid higher prices for coffee of higher quality.

Like an increasing number of coffee producing cooperatives, all three cooperatives in this study have experience as dually Fair Trade and organic certified. In their 2007 study, Giovannucci and Villalobos found that $78 \%$ of all Fair Trade certified coffee sold in the US is also organic certified. Though Fair Trade requirements include an element of environmental protection, they were designed to pertain more to "relations of exchange and relations of production" (Hudson and Hudson 2004:130). For its part, Fair Trade offers stability in a minimum price guarantee, so that farmers can anticipate their annual income and adjust their spending accordingly. Organic certification, on the other hand, is viewed as a prescription of growing practices that results in a higher quality and, therefore, more valuable coffee. However, producers in this study made little distinction between the two forms of certification, discussing organic growing requirements as part of their participation in Fair Trade markets and using the two terms interchangeably. By producing coffee with more control, more careful observation of best practices, coffee growers believed they could increase the quality of their product to meet export standards and enter 
preferred markets. In this way, Fair Trade and organic certification seemed to present coffee growers with an opportunity to proactively increase the value of their product. As one resident of La Esperanza explained:

It is an advantage. The experiences I have had in so many visits I have made to conferences in the United States, and like the Conference I went to in Germany, I noticed that the organic market is growing. As much in coffee as in macadamia. It's there. And the good thing is that it's not only in this, no, it's is various products. So if we continue in this direction, I think we will be able to compete. Because now there are few people in the organic market. -Timoteo (interview, December 2, 2009)

In practice, however, many coffee growers express dissatisfaction with the economic results of selling though the Fair Trade system. Certification requirements, particularly those for organic certification, constrain generationsold cultivation practices and generate new labor demands, all in the name of environmental responsibility and improved quality. Many farmers struggle to meet these requirements, rising to the challenge by pulling resources from family labor, loans, or diverting their own income-earning strategies. As families and communities are differentially prepared to meet these increased labor demands, not everyone reaps the same financial benefits of participating in the Fair Trade network.

Meanwhile, the international price of coffee continues to escalate. In the early 2000s, the Fair Trade and organic price offered a significant advantage over conventional market sales. Producers received the guaranteed minimum of $\$ 1.55$ for certified coffee while international coffee prices continued to disappoint at less than $\$ .50$ per pound. In 2005 , however, coffee prices broached the $\$ 1.00$ per pound mark, lessening the differential between 
conventional and certified sales, and, for many, raising doubts about whether or not certification was a worthwhile endeavor. Because steadily increasing temperatures and out-of-season rainfalls, commonly attributed to global climate change, are jeopardizing production volumes of Arabica coffee in major coffee growing regions, coffee prices have continued to rise, setting new peak price records for the 2010-2011 harvest (Rosenthal 2011). By the end of January 2011 , the price had already reached $\$ 2.45$ per pound, and both producers and purchasers alike expected the rising trend to continue. As a result, enthusiasm for Fair Trade has begun to waver, as one cooperative member explained, "So in the beginning, I think it was really good. Fair trade for us, we had a secure product price. But over the course of the years, Fair Trade has stayed here and the national prices have gone up... staying only with Fair Trade, we stay below and the conventional prices are taking off." (Cristóbal, interview, February 2, 2010)

This chapter explores the direct economic impacts of selling through Fair Trade certified channels by comparing the commodity chain of certified Fair Trade coffee with two additional market systems - relationship coffee (another form of fair trade) and conventional coffee - to illustrate the financial structure of coffee commercialization in each community.

\section{THREE MODELS FOR MARKET PARTICIPATION}

Central to the mission of fair trade is aim of altering the commodity chain for coffee. Proponents claim that by shortening the commodity chain, or eliminating some of the middle-men separating producers from consumers, 
fewer firms will extract money from the final price received by coffee growers, thereby returning to producers more money for their coffee. Coffee growers, too, follow this logic, and producers in all three communities stress the importance of establishing direct trade.

Fair Trade certification offers one route to more direct trade, but eventually growers in each cooperative conclude that Fair Trade is not direct enough. Alta Gracia has responded by establishing trade as a "relationship coffee". They have abandoned certified Fair Trade and its accompanying fees to partner directly with alternative trade roaster and sell coffee marketed as "produced under fair conditions". In Bella Vista, where several residents likened the certification requirements to esclavitud (slavery) and their days as finca workers, the community has split into two separate growers' cooperatives; the Grupo Organico continues to sell coffee through Fair Trade and organic channels, while the Grupo Convencional sells at the national level for prices determined in accordance with the international market La Esperanza has abandoned Fair Trade altogether, reverting back to sales in the national market while aspiring to sell directly to a purchaser in the US.

Direct trade would be an advantage in that the earnings that we leave with Toro Verde [the Fair Trade umbrella cooperative] for processing and everything, transportation, loans that we take, I think that in place of supplying all this money to them, we would deal directly with the buyer. It would go to the company that buys our coffee. I think that this would lower [costs] a lot, a lot. It would lower them so much. The interest and the earnings that stay with Toro Verde would be ours. Celestino (interview, December 1, 2009)

These commodity chains differ significantly in structure and length, and research reveals that their economic outcomes are significantly different, 
though perhaps in unexpected ways. In this comparison, the shorter commodity chain is, in fact, associated with greater profits than are acquired through conventional sales. The shortest of the three chains, however, is not associated with greater profits as the literature and proponents of fair trade and direct would suggest. This chapter demonstrates that the benefits of a shorter commodity chain can be offset by cooperative composition and production volumes, which affect the financial burden of certification costs shouldered by cooperative members, thus erasing any financial gains to be made through a more direct market system such as relationship coffee.

\section{Fair Trade certified cooperative}

Because this community has split into two producer cooperatives, the commodity chain demonstrates the difference in structure between a Fair Trade and conventional market system. The left side of the graph depicts the flow of coffee from producer to consumer in a Fair Trade certified channel, while the right side traces the path of coffee through a conventional market path, a route taken by the majority of coffee growing cooperatives in Guatemala. 
Figure 4.1 Commodity chains of Bella Vista

Grupo Organico

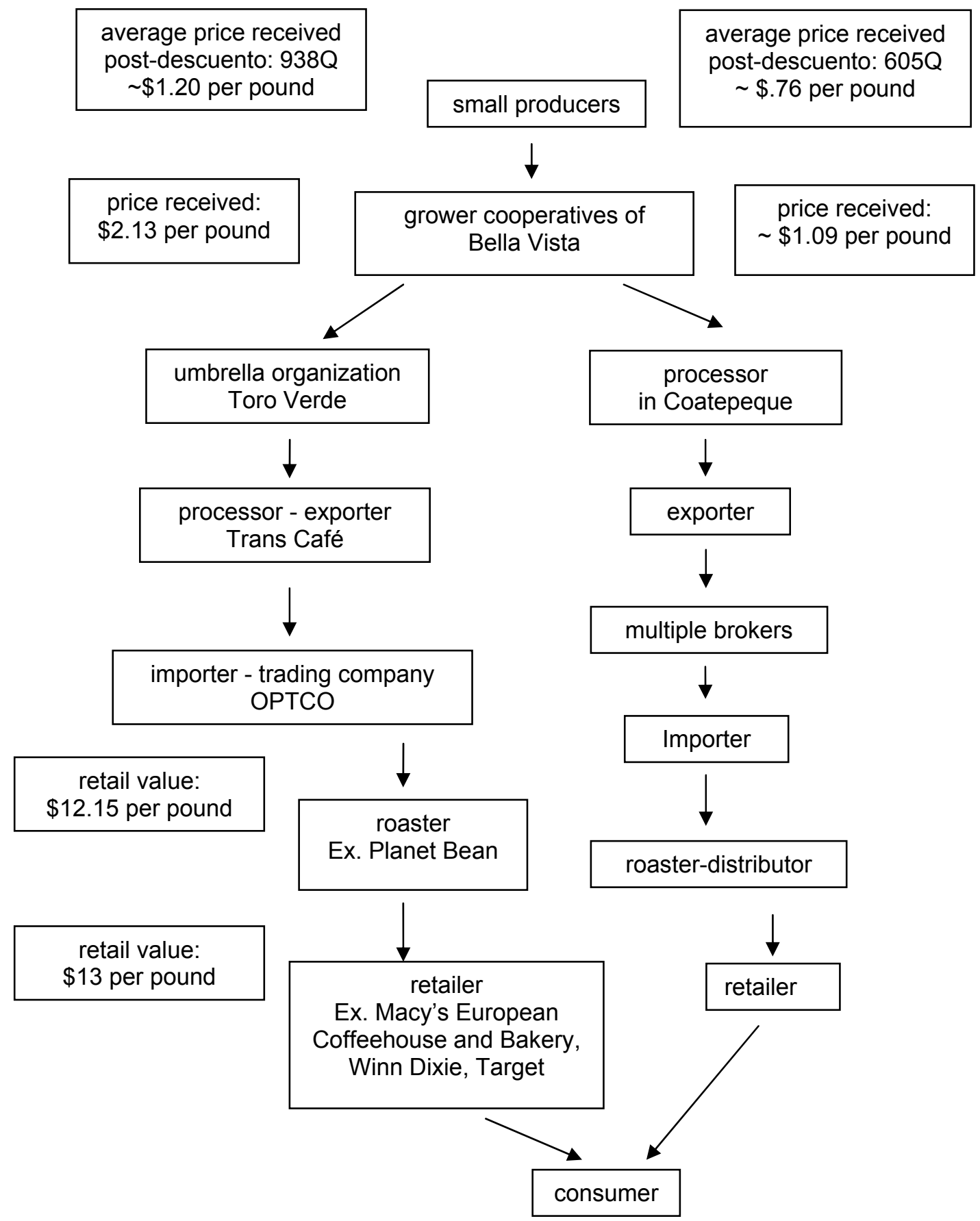

In both cases, coffee produced by individual growers is deposited at the beneficio to be processed for one of two cooperatives. In the past, all growers in this community deposited coffee in a single beneficio to be processed and 
sold collectively. Since the split in 2007 into the Grupo Organico and Grupo Convencional, the use of all facilities has been divided into two, so that coffee is weighed and evaluated by either Organico or Convencional staff, fermented in the corresponding tanks, dried on the appropriate patio, and stored the assigned area of the bodega, or storage facility.

It is at this point, when coffee leaves the community, that the market paths diverge. Coffee produced by the Grupo Organico is sent to the Trans Café bodega in Escuintla to be evaluated for quality and prepared for shipment. While the cooperative can be certain of the amount of coffee they send to the bodega, they will not know the final volume deemed of acceptable quality for export until it passes through the Trans Café bodega. The coffee never physically passes through a Toro Verde facility, but some of the actions assumed by this umbrella cooperative are associated with this stage of production. The fees for these actions, or descuentos, cover costs such as the export license, transportation to the US, and Fair Trade certification. Therefore, Toro Verde is depicted here as an additional firm involved in the commodity chain for Fair Trade coffee. For this reason, though Toro Verde states they pay their member cooperatives $\$ 2.13$ per pound, the actual pay rate known in the community $-1140 \mathrm{Q}$ per pound, or $\$ 1.46$ per pound reflects the price paid to the community after the descuentos have been deducted. It should be noted, however, that the price quoted by community residents reflects the addition of the social premium intended for use in community development. Seeing the conventional market rate rise 
dangerously close to the Fair Trade per-pound price, Grupo Organico members voted to divert community development funds into their per-pound price, thereby bolstering their price to maintain an advantage over conventional production.

After leaving the Trans Café bodega, Grupo Organico coffee is sent to the US where it is received by an importer. Toro Verde works with several importers, including Organic Products Trading Company (OPTCO), Equal Exchange, Royal Coffees, and Sustainable Harvest. Toro Verde's importers gather thousands of hundred- pound sacks of coffee for sale to roasters such as Planet Bean and Green Mountain, the latter being one of the best-known organic coffee roasting companies in the US. Roasters may sell coffee by the pound to individual consumers, or they may supply additional retailers such as grocery stores and coffeehouses. The retail value of this coffee, upon sale to the final consumer, ranges from $\$ 8.49$ to $\$ 13$ per pound. While many Fair Trade certified coffees are sold in a blend of cooperatives, countries, or regions, at least one US retailer sells Bella Vista coffee as a single-origin coffee valued at $\$ 12.15$ per pound.

Producer knowledge of this chain, however, is quite limited. Despite the fact that Bella Vista's coffee has been contracted to the same purchaser for the last ten years, a purchaser who visits the community every year or two, no one in the community could recall either the name of their purchaser or his importing company. In fact, while some members of the Grupo Organico ventured a guess as to the final destination of their coffee - perhaps Holland? 
Japan? Probably the United States? - only $50 \%$ of survey respondents were able to name with certainty a single site through which their product passed after leaving the community, and only one respondent correctly named the US as the country in which their coffee is sold. Upon asking respondents to name the retail value of their product in the export market, residents often shook their heads and replied, "Saber!" a reply akin to the English hypothetical, "Who knows?" with little expectation for or interest in an answer. Though one cooperative member was able to name the retail per-pound value for their packaged coffee in the local market, no one could estimate the price commanded in the export market.

Even less is known about the ultimate fate of coffee sold through the conventional system. Coffee produced by the Grupo Convencional is sold in lots in accordance with favorable market conditions. After the formation of this separate cooperative, Grupo Convencional members revisited their former purchaser in Coatepeque to whom the Bella Vista cooperative sold coffee prior to Fair Trade and Organic certification. One cooperative member is now charged with contacting this purchaser for the latest quotes on coffee prices, then Grupo Convencional members meet and vote to sell their harvest or hold out for better prices. For the 2009-2010 harvest, Grupo Convencional recalled selling one lot of coffee for $850 \mathrm{Q}(\$ 1.09)$ per pound and the second lot for 900Q (\$1.15) per pound. No specific details are known of the destination of Grupo Convencional coffee beyond the bodega in Coatepeque. Growers do not know where the coffee is sold or the final retail price. 
Illuminating the practical significance of sales through the Fair Trade versus the conventional market system is difficult, as deductions from the contract or market price are made at each stage of production. The per-pound price offered by the umbrella cooperative obscures the deductions associated with participation in the system, including export and certification fees. Similarly, the price to farmers associated with either cooperative obscures further fees for processing in the community facilities, the amount varying by the total volume of coffee collected and deducted from each family's final profits. Moreover, deductions can include cancellation of debts owed to the cooperative. Because of the nature of payment for an annual-harvest commodity, many farmers request loans throughout the course of the year to cover production costs such as labor and materials. Though loans offered through Toro Verde bear relatively low interest rates $(9 \%)$, the interest as well as the principal both further erode the final profits received by producers.

The final post-descuento profits reported by coffee growers, then, provide a more informative indicator of the economic impact of the Fair Trade. The per-pound price displayed in the chart reflects the average of each group's producers' per-pound profits, calculated by dividing the final profits for coffee turned into the cooperative for the 2009-2010 harvest by the number of 100-pound sacks turned into the cooperative for each member family. This reveals that Grupo Organico members ultimately received a rate of $938 \mathrm{Q}$ (\$1.20) per pound, with an average of 9 quintales of coffee produced, for a profit of $8442 \mathrm{Q}(\$ 1082)$. Grupo Convencional members, on the other hand, 
received a rate of $605 \mathrm{Q}(\$ .78)$ per pound, with an average of 9.8 quintales turned in to the cooperative, for an average profit of 5929Q (\$760) for the year.

This reveals a significant difference in the profits returned to producers selling coffee through a Fair Trade system rather than a conventional system. Members of Grupo Organico received 333Q (\$.43) per pound more than their conventional neighbors. Furthermore, even after the deductions for the services administered by Toro Verde and their own cooperative, Grupo Organico members received $82 \%$ of the price paid to their cooperative, while Grupo Convencional members retained only $69 \%$ of the price for which their coffee was sold to the beneficio. Judging by the contracted coffee price, the price paid to the cooperative, or the final pay rate received by producers, the Fair Trade market system appears to offer a considerable economic advantage over the conventional market system.

These percentages, however, appear contrary to producers' general impressions of the benefits and drawbacks of selling through the Fair Trade certified chain. In of their primary motivations for exiting the Fair Trade market system, Grupo Convencional were highly critical and resentful of the deductions taken by Toro Verde, feeling they retained more of their own money by selling conventionally. Viewed differently, then, Grupo Organico only retains $56 \%$ of their contracted price, while Grupo Convencional members receive $70 \%$ of the price at which the cooperative opted to sell. The disparity between what was promised and what was actually received more effectively 
explains the frustration of Grupo Convencional members with their Fair Trade experience.

Relationship coffee cooperative

When Alta Gracia first began selling coffee through Fair Trade and organic channels, they produced over three times the amount of coffee they are producing today. As one cooperative member explains:

The first year we couldn't export, not until the $2^{\text {nd }}$ year. And I was president then, the legal representative of the association. And we proposed that in that year we would export. And we did. The first export went to Germany. We exported 405 quintales of café oro (green coffee). It was a lot. In the bodega we turned in 530 [quintales] in pergamino. And of that, 405 left in oro. - Ciriaco (interview, March 8, 2010)

However, the community still has yet to recover from the devastation of Hurricane Stan in 2005. In its wake, FLO imposed the first certification fees to be paid by communities, a burden this struggling cooperative could not bear given their meager coffee production, currently producing less than 125 quintales of export-grade coffee per year. As a result, the cooperative's purchaser in the US, Roundtable Roasters, suggested that, given their circumstances, certified Fair Trade may not be the most beneficial form of market participation for the cooperative of Alta Gracia. Instead, they suggested a more direct trade agreement between buyer and producer, participation in the Fair Trade Federation, and marketing coffee as "produced under fair conditions" rather than pay for Fair Trade certification.

The Alta Gracia commodity chain reflects the market path of coffee sold through a fair trade, though not certified Fair Trade, channel. It is termed here 
as "relationship coffee" due to the close nature of exchange and trust between the purchaser and producer cooperatives. Relationship coffee is defined by Sustainable Harvest as "an alternative business model to the traditional coffee supply chain. It operates with complete transparency and brings coffee farmers, importers, and roasters together on a level playing field." (Sustainable Harvest N.d.)

The purchaser cooperative in this model is self-described as "a workerowned coffee roaster dedicated to creating and expanding a model of trade based on transparency, equality, and human dignity. We strive to build longterm relationships with small-scale coffee growers to bring you a truly incredible cup of coffee." (Just Coffee N.d.a) 
Figure 4.2 Commodity chain of Alta Gracia

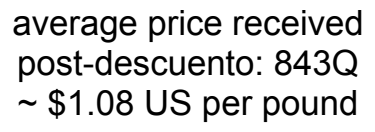

average price received post-descuento: $843 \mathrm{Q}$ $\sim \$ 1.08$ US per pound

price received: $\$ 2.00$ US per pound (minimum) price received: $\$ 6-7.20$ per pound

retail value:

$\$ 9-13$ per pound small producers

grower cooperative

Alta Gracia la Union
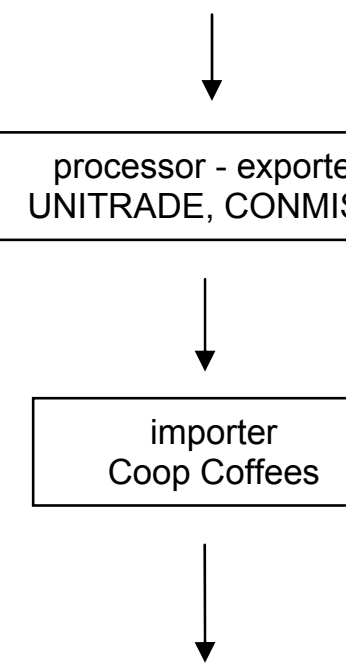

roaster-retailer Roundtable Roasters

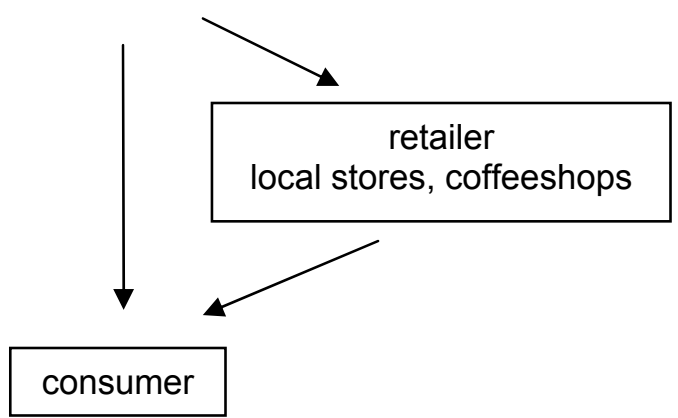

In Alta Gracia, all but four families have consistently deposited their coffee in the beneficio for sale in the cooperative. For the dissenters, their objection with the cooperative lay more with the administration of finances than with the market system. In fact, since a recent overhaul of the coffee commercialization staff, these four dissenters have not only vowed a return to the cooperative, but they have assumed administrative roles in the community. 
All cooperative members deposit their coffee in the community beneficio, where it is weighed, documented, evaluated for uniformity of color, and aggregated for fermentation. After fermentation, quality selection, patio drying, and packaging, the coffee is taken to the processing facilities in Mazatenango. From this processor and exporter, coffee is received in the US by Cooperative Coffees, a collectively owned cooperative of coffee roasters and a member of the Fair Trade Federation, though not Fair Trade certified. The Fair Trade Federation distinguishes itself as a network of businesses more closely resembling the original vision of Alternative Trade Organizations, though it does not offer product certification. Therefore it can be described as a model of fair trade, though not Fair Trade ${ }^{\mathrm{TM}}$. Members value transparency in exchange and personal contact with producers, frequently offering prices above the established FLO minimum.

After receipt by Coop Coffees and final quality evaluations, the coffee is sent to the partner roaster, Roundtable Roasters. There it is roasted, packaged, and prepared for sale both by the pound to individual consumers and wholesale to local and nationwide retailers and coffeehouses, where it may be sold packaged or as drip coffee.

In an effort to promote transparency in trade, Roundtable Roasters posts documents such as producer contracts and payment information, as well as a diagram of their supply chain indicating the processing and value-adding which contribute to the retail price of the coffee (Just Coffee N.d.b). According to Roundtable Roasters, roasted coffee is sold wholesale for $\$ 6-7.20$ per 
pound. This cost reflects the prices paid to producers along with the following per-pound costs:

Figure 4.3 Processing costs reported by Roundtable Roasters

\begin{tabular}{|l|l|}
\hline$\$ .60-.80$ & Shipping, storage, and freight \\
\hline .50 & Label and packaging \\
\hline 1.90 & Labor costs and roasting \\
\hline 1.90 & Roundtable Roasters overhead expenses \\
\hline
\end{tabular}

Because Cooperative Coffees aims to honor the minimum price paid by FLO, they contract with producer cooperatives at a rate of $\$ 1.50$ to $\$ 2.20$ per pound, with the additional $\$ .10$ per-pound premium offered by FLO. However, the staff at Roundtable Roasters views the FLO price as unfairly exclusive of the rising cost of living in many countries where Fair Trade producers are located. According to the Fair Trade Federation, "Fair wages are determined by a number of factors, including the amount of time, skill, and effort involved in production, minimum and living wages in the local context, the purchasing power in a community or area, and other costs of living in the local context." (Fair Trade Federation N.d.) Therefore, beyond this base price, Roundtable Roasters typically supplements the Coop Coffees price with an additional premium to bring the coffee price up to at least $\$ 2.00$ per pound. As Darrell (interview, September 10, 2009) of Roundtable Roasters explains,

Two or three times a year we'll send them premium checks, based on getting the coffee that we buy from them up to a certain price-per-pound level, right? So Coop Coffees will sign a contract with Alta Gracia at $\$ 1.90$, just for example, and then we've contracted that we'll pay them $\$ 2.05$. So we track what we sell, send them a premium check to get them up to that $\$ 2.05$, and do that two or three times a year... If you adjust the price from when it was established eighteen years ago or whatever, it should be over two dollars in the United States. And so it's hard to really say, "Oh, we're making sure that it's fair trade," without addressing that issue, too. 
According to Kenneth (interview, September 11, 2009) of Roundtable Roasters, for the 2008-2009 harvest, the result of the contracted price plus their additional premium was that the Alta Gracia cooperative ultimately received $\$ 2.15$ per pound of coffee. The final liquidation documents show that Roundtable Roasters again paid $\$ 2.15$ per pound for the 96 bags of coffee they received from the 2009-2010 harvest (Just Coffee 2009)

The final retail value of packaged Alta Gracia coffee ranges from $\$ 9-13$ per pound. Of this amount, Roundtable Roasters claims that growers receive between $\$ .50$ and $\$ 1$ per pound of coffee sold through their relationship market system. The disparity between the price paid to the cooperative and the price received by producers reflects the deductions taken for services rendered by the cooperative, such as processing in the beneficio, transport to the bodega, and organic certification. Calculating prices to growers using the method described above yields a higher price to growers, with survey respondents reporting an average of $\$ 1.08$ per pound after deductions. The higher price resulting from survey data is likely attributable to pay increases since the creation of Roundtable Roasters' supply chain map and subsidies Alta Gracia has received from outside sources to defray costs of production.

In contrast with the coffee growers in either group in Bella Vista, members of the Alta Gracia cooperative named several stages of production beyond their own farm gate, including the town in which coffee was processed before export, the name of their purchasing roaster and importer, as well as a few employees, and even the location of the Roundtable Roasters office. Of 
the 23 survey respondents, $70 \%$ were able to name at least one destination for coffee beyond the farm gate, usually the name of their buyer, and $30 \%$ named two or more destinations. Still, Alta Gracia cooperative members are little more aware than their Fair Trade certified counterparts of the final retail value of their product. Only $13 \%$ of respondents named a price within the range indicated by Roundtable Roasters.

The shorter commodity chain of Alta Gracia's relationship coffee system may explain the greater familiarity of its members with their purchasers, since Roundtable Roasters representatives make several trips per year to visit the community and maintain steady contact with the President of Commercialization. However, in contrast with expectations, a comparison of Alta Gracia and Bella Vista reveals the system with the longer chain, the Fair Trade certified system, as returning to producers a higher per-pound price, even despite Alta Gracia's higher contracted price and price to the cooperative. Assuming Alta Gracia only received the minimum $\$ 2.00$ per pound that Roundtable Roasters strives to guarantee, a conservative estimate, they passed only $54 \%$ of this amount on to individual growers, while Bella Vista's Grupo Organico retained $56 \%$ of their $\$ 2.13$ to return to cooperative members. For the 2009-2010 harvest, when Alta Gracia received \$2.15 per pound, the percentage of the contract price ultimately received by cooperative members would be even less.

The unique history of Alta Gracia's cooperative, combined with the location of the farm and the resources with which they are equipped help 
explain the failure of a shorter commodity chain to return higher profits to producers. As in Bella Vista, Alta Gracia's partnership with Fair Trade Federation members grants them access to loans to pay for productions costs. In Alta Gracia, a large portion of income is consumed by paid labor. Of the three communities compared in this study, Alta Gracia cooperative members rely most heavily on paid labor, with $83 \%$ of residents hiring laborers in the last year, compared to $61 \%$ in Bella Vista and $56 \%$ in La Esperanza. Among those in Alta Gracia who hired laborers in the last year, residents spent an average of 5211Q (\$668 US), followed by La Esperanza members spending an average of $4589 \mathrm{Q}$ ( $\$ 588$ US), and members of Bella Vista's Grupo Organico and Grupo Convencional spending just 1386Q (\$178 US) and 2208Q (\$283 US), respectively.

Reasons for the frequency of hired labor in Alta Gracia are numerous and closely related to their status as a resettled guerrilla cooperative. As a result of their time spent in exile and losses of family members during the war, families and households in this community are smaller than those in the other two communities. Parents had an average of three children, compared with five in La Esperanza and six in Bella Vista. Households, too, were smaller, with an average of five members in Alta Gracia, six per household in La Esperanza, and seven in Bella Vista. Smaller households and fewer children mean Alta Gracia's residents have fewer hands to help in coffee cultivation, so residents pay for the labor assistance they need. Furthermore, many residents have no history in coffee cultivation. They may hire laborers to help them work 
more efficiently and effectively. Some cooperative members feel better prepared for off-farm employment, and since Alta Gracia is located relatively near a major transportation hub, these residents opt to hold paid employment in Coatepeque or Guatemala City while paying laborers to work the coffee in their absence. In fact, $50 \%$ of survey respondents in Alta Gracia had paid employment outside coffee cultivation, compared with $32 \%$ of respondents in Bella Vista and $26 \%$ of La Esperanza members.

These factors also help explain the low production volume of Alta Gracia's producers. The majority of residents $(87 \%)$ do not come from a background of coffee cultivation. Including those who worked as coffee pickers during their time in exile in Mexico, only $26 \%$ of residents had experience in coffee production prior to settlement in the community. As a result, coffee production is more time consuming, growers require more assistance from paid laborers, and their overall production is disconcertingly low. For the 20092010 harvest, Alta Gracia residents produced an average of six quintales of coffee, compared with eight in La Esperanza and nine in Bella Vista. More concerning than last year's low yield is the fact Roundtable Roasters' sales records reveal production volumes have been declining steadily over the course of the last three harvests, and the cooperative is struggling to fill their contracts. No matter how favorable a price Roundtable Roasters or Cooperative Coffees can offer, it makes little economic difference if there is no production to garner earnings. 
Finally, the prevalence of paid labor in Alta Gracia paired with the low production volumes, hence disappointing earnings, means residents are seeking ways of paying for their significant labor costs and other household expenses. One solution practiced by many in this community is selling portions of coffee outside their contract agreement. Although Roundtable Roasters offers coffee payments in installments rather than a single lump sum, producers still feel incapable of bearing the cost of production and raising a family. Like Bella Vista residents, they have the option to take out loans to cover labor costs, but the interest rates, though relatively low, would further diminish coffee profits. As a result, cooperative members often sell a portion of their harvest early to one of the many coyotes who visit the easily-accessible community. In the $2009-2010$ harvest, $75 \%$ of members reported selling coffee outside the cooperative. Because it is a violation of their contract, cooperative members often claim to sell only verde, the green, unripe coffee that is unacceptable in the beneficio because it would compromise the quality of the overall coffee product. Careful coffee picking, as required for organic certification, should yield only a small, accidental, yet unavoidable amount of verde, certainly less than a quintal. However, members who sold coffee outside the cooperative reported selling an average of 3 quintales of coffee to outside buyers.

Just as complex as the pressures compelling this breach of contracts are the effects of the trend. Not only do cooperative members consistently fail to provide the amount of coffee they are contractually obligated to produce, 
but the burden of the deductions made for processing in the beneficio, organic certification, transportation, among other costs, cut even deeper into the profits for each pound of coffee sold through this relationship coffee channel.

The ledger of one cooperative member effectively demonstrates the devastating effect this combination of high labor costs and low cooperative production can wreak on coffee profits. For this producer, production costs for the 2009-2010 harvest included:

Figure 4.4 Production costs of one grower in Alta Gracia for 2009-2010 harvest

\begin{tabular}{|c|c|c|}
\hline \multirow{3}{*}{ Individual costs } & $1480 \mathrm{Q}(\$ 190 \mathrm{US})$ & La tapisca (coffee harvest) \\
\cline { 2 - 3 } & $600 \mathrm{Q}(\$ 77 \mathrm{US})$ & La poda (pruning trees) \\
\cline { 2 - 3 } & $1800 \mathrm{Q}(\$ 231 \mathrm{US})$ & La limpieza (weeding, clearing land) \\
\hline Cooperative costs & $560 \mathrm{Q}(\$ 72 \mathrm{US})$ & Beneficiar (processing on-site) \\
\cline { 2 - 3 } & $1065 \mathrm{Q}(\$ 137 \mathrm{US})$ & La retriya (processing off-site) \\
\hline
\end{tabular}

This producer ultimately turned in to the cooperative seven quintales of coffee, one quintal more than the average production of cooperative members. To cover costs of production, this producer was deducted $560 \mathrm{Q}$ for processing in the community, and another 1065Q for off-site processing. Considering the contracted price of $\$ 1.83$ per pound, or $\$ 183$ (1427Q) per quintal, one quintal of this producers' harvest covered the costs of processing his coffee. Eventually he received $5540 \mathrm{Q}$ ( $\$ 710$ US) payment for his contribution to the cooperative's harvest. But because this producer holds outside employment, working in the capital every other week as a security guard, his family hires laborers when he is unavailable to carry out time-sensitive tasks in cultivation. Therefore, his coffee profits are further diminished by the considerable amount of money - 3880Q $(\$ 497)$ - he invested last year in paid labor. 
Despite the favorable price that the Alta Gracia cooperative receives from their purchaser, their low volume of production leaves little room to distribute the costs of processing. For this reason, cooperative members consistently described their coffee price as "muy bonito" (really nice), but stressed the point that without any quantity to sell at such good prices, the money "no alcanza" (is not sufficient).

For example, I only cut 4 quintales this year. That comes out to $4000 \mathrm{Q}$ or less. That's not enough to feed my family. Who can survive on 4000Q a year? Because, if I say I'm going to live off the land, I'd have to cut 30, 40 quintales in pergamino. In that case, I could say, "Yes, this helps." But with 4 quintales it doesn't do anything. And that's if you can get that much coffee. We all have the same amount of land. If we work it really, really well, we could get 1 quintal per cuerda. That would be 30 quintales [per person]. But it could be more, it could be $1 \frac{1}{2}, 2$ quintales per cuerda. If I have 30 cuerdas, that comes out to 60 quintales. That way I could say, "Good, I will just work my land and live on that." I wouldn't have to work outside. But that's not how it is. It's a very difficult situation. - Rodolfo (interview, March 15, 2010)

The supply and demand imbalance, combined with the unavailability of unpaid household labor, attributable to both small family sizes and husbands working outside the community, has left residents in a situation where their primary source of income is questionably lucrative.

The no-longer Fair Trade cooperative

The commodity chain for this cooperative reflects a conventional coffee market path. The community received financial support for Fair Trade and organic certification, and for a single year they were members in the producer cooperative network of Toro Verde. For the 2009-2010 harvest, La Esperanza's coffee followed the same path illustrated above for Bella Vista's 
Grupo Organico. However, after a single year of participation in the Fair Trade market they have returned to the conventional system.

Figure 4.5 Commodity chain of La Esperanza
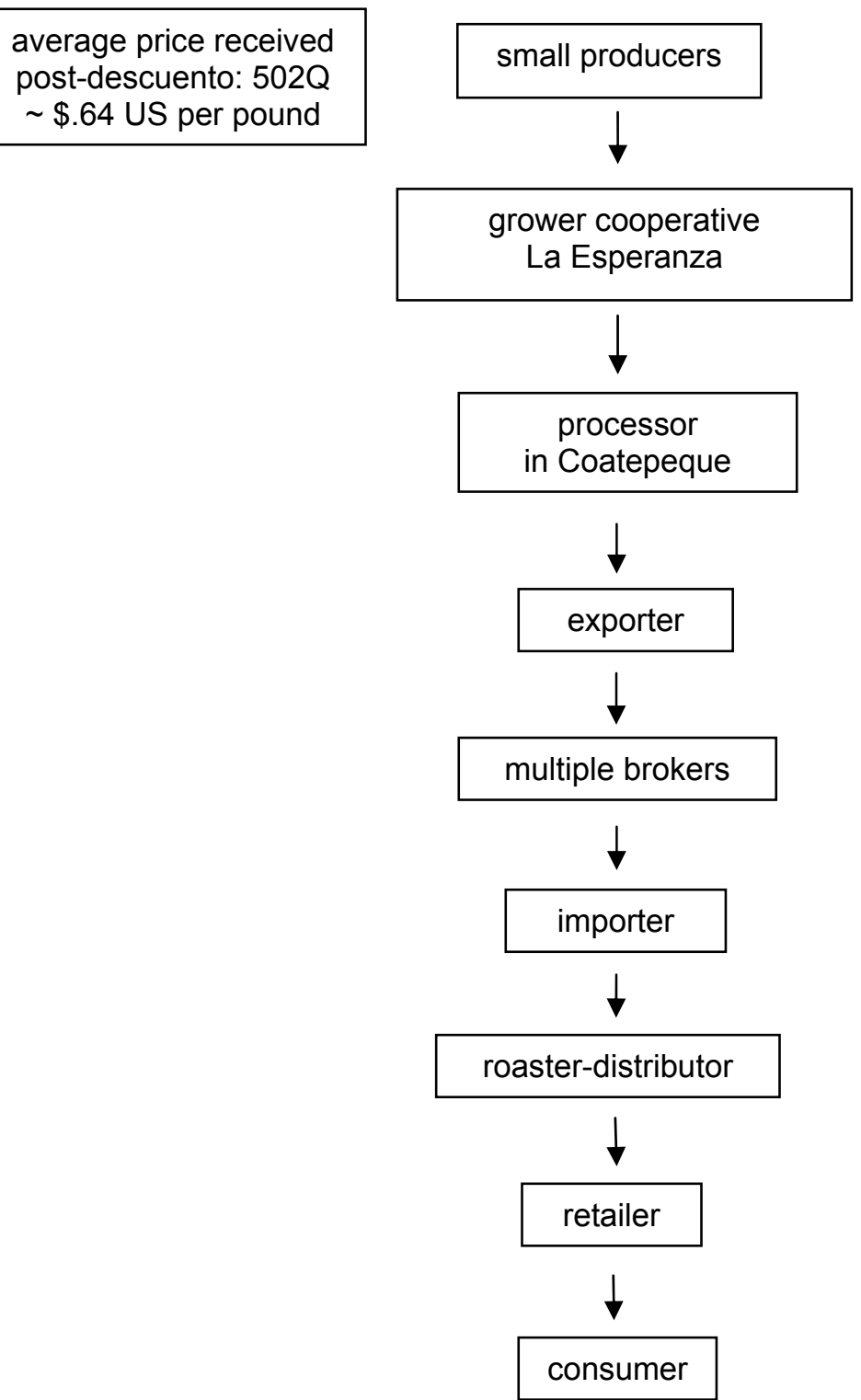

Coffee collection remains unchanged, with all residents depositing their sacks of coffee in the community beneficio. Perhaps because individualized land holdings are such a new feature of the community, only a single survey 
respondent reported selling coffee outside the community. This is in stark contrast with the other two communities, where sales outside the cooperative, either to access quick money or avoids paying on debts to the cooperative, is a highly contentious issue.

Also in contrast with the other two communities, the beneficio in this cooperative has been run by the same supervisor since the community was resettled in 2002. The turnover rate is high among beneficio staff, due in large part to the grueling physical demand of loading, unloading, and managing 100-pound (or more when wet) sacks of coffee, as well as the rigorous work schedule maintained by the supervisor. Both Bella Vista and Alta Gracia have trained new beneficio supervisors since 2008, and suffered a lapse of coffee quality in the process.

After coffee is collected, it is depulped to remove the outer shell, then proceeds to the fermentation tanks, where the coffee beans soak until the miel (mucilage) decomposes and can be washed off the bean. This process results in two byproducts; the pulpa (pulp) can be used for organic fertilizer, while the runoff water can contaminate groundwater and local waterways if not treated prior to release. Next, the coffee beans ushered through a series of water-filled channels where the poor quality beans that float are sifted off the surface of the water, leaving the higher quality beans that sink to the bottom to be pushed along to subsequent channels until all that remains is the primera, the highest grade coffee produced by the cooperative. 


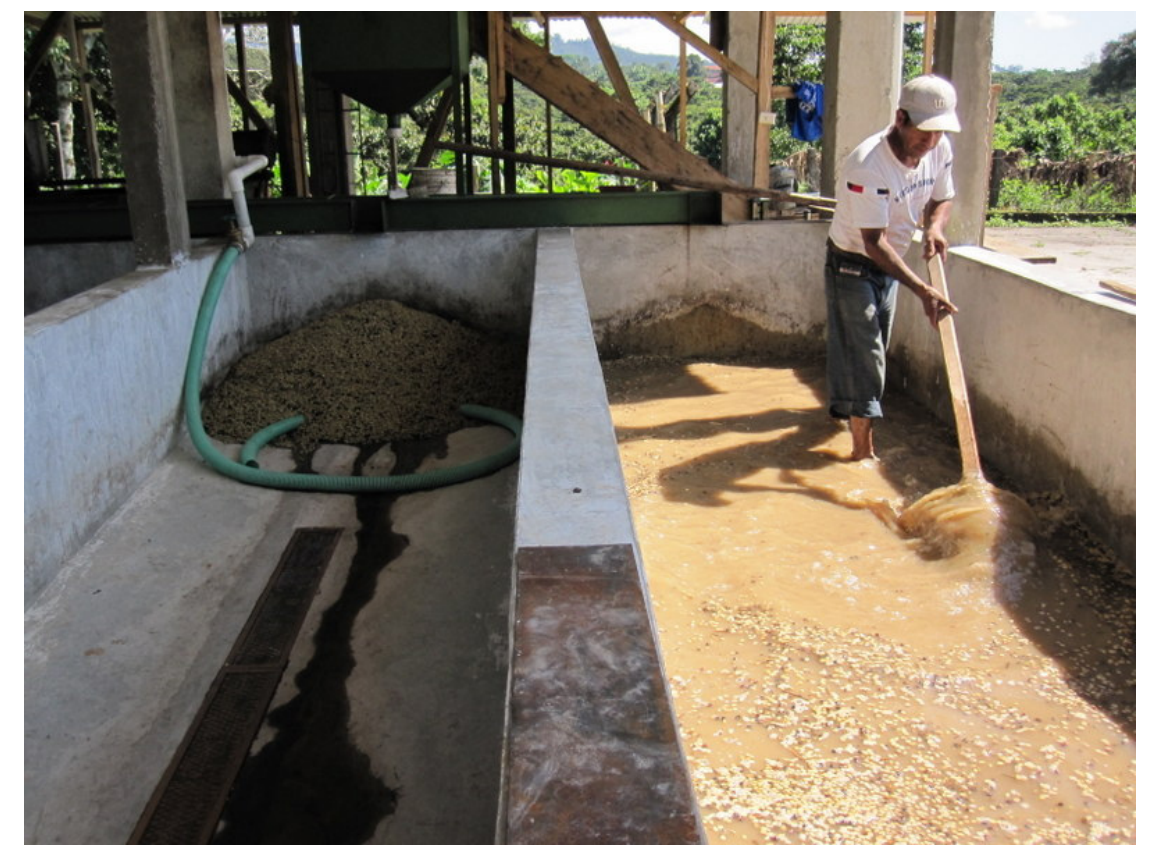

Figure 4.6 Beneficio work: pushing the depulped, fermented, and rinsed coffee beans into a flotation channel

All the beans, the primera as well as the segunda, or second-grade (and often broken down into community-specific terms describing the color, shape, and health of the bean), are dried on the patio for four to six days, depending on the hours of sun available each day. In La Esperanza, coffee is turned over every fifteen minutes to maintain even drying. After the primera is sufficiently patio-dried, it is finished in the diesel-fueled tumble dryer and then deposited into 100-pound sacks to prepare for transport.

For the 2009-2010 harvest, sacks were weighed, sewed shut, and marked with Toro Verde label indicating the cooperative name, the beneficio supervisor, the date, and a lot number. Finally, the shipment was ready for delivery to the Trans Café bodega in Escuintla. In 2009, La Esperanza made two deliveries to Escuintla, each about 150 quintales apiece. This represents about $75 \%$ of the cooperative's total harvest that year. This amount, a total of 
about 300 quintales, was considered below average, as the cooperative more often produces between 600 and 700 quintales in a year. The relatively low harvest was attributed to the tendency of coffee to alternate high and low years of production as well as overgrown macadamia trees that provided excessive shade for the coffee trees and hampered growth at full capacity. Because travel on the isolated roads connecting La Esperanza to the nearby transport hub of Retalhuleu is known to be haunted by robbers, the shipment leaves around 5 a.m. under the cover of darkness, with an armed security guard perched atop the cargo in each of two trucks. The delivery to Escuintla is an all-day affair, with a minimum 3-hour drive each way, possibly more depending on traffic. At the bodega, workers strap on weight lifting belts and manually unload each of the 150 or so sacks from the back of the truck, forming a pile to be stored inside before the rigorous quality checks begin.

At the Trans Cafe bodega in Escuintla, La Esperanza's coffee was sorted and stored according to the same process as Bella Vista's coffee. The following flowchart depicts the typical stages undergone by coffee that is wet processed as that of these three communities. All tasks beyond those conducted at the "drying station" are carried out off-site at the bodega. One exception is the elimination of the película, the "silver skin" or chaff, surrounding the coffee bean. Roundtable Roasters, for example, purchases coffee beans with the película intact, to be removed during the roasting process. 
Figure 4.7 Flowchart illustrating the wet process

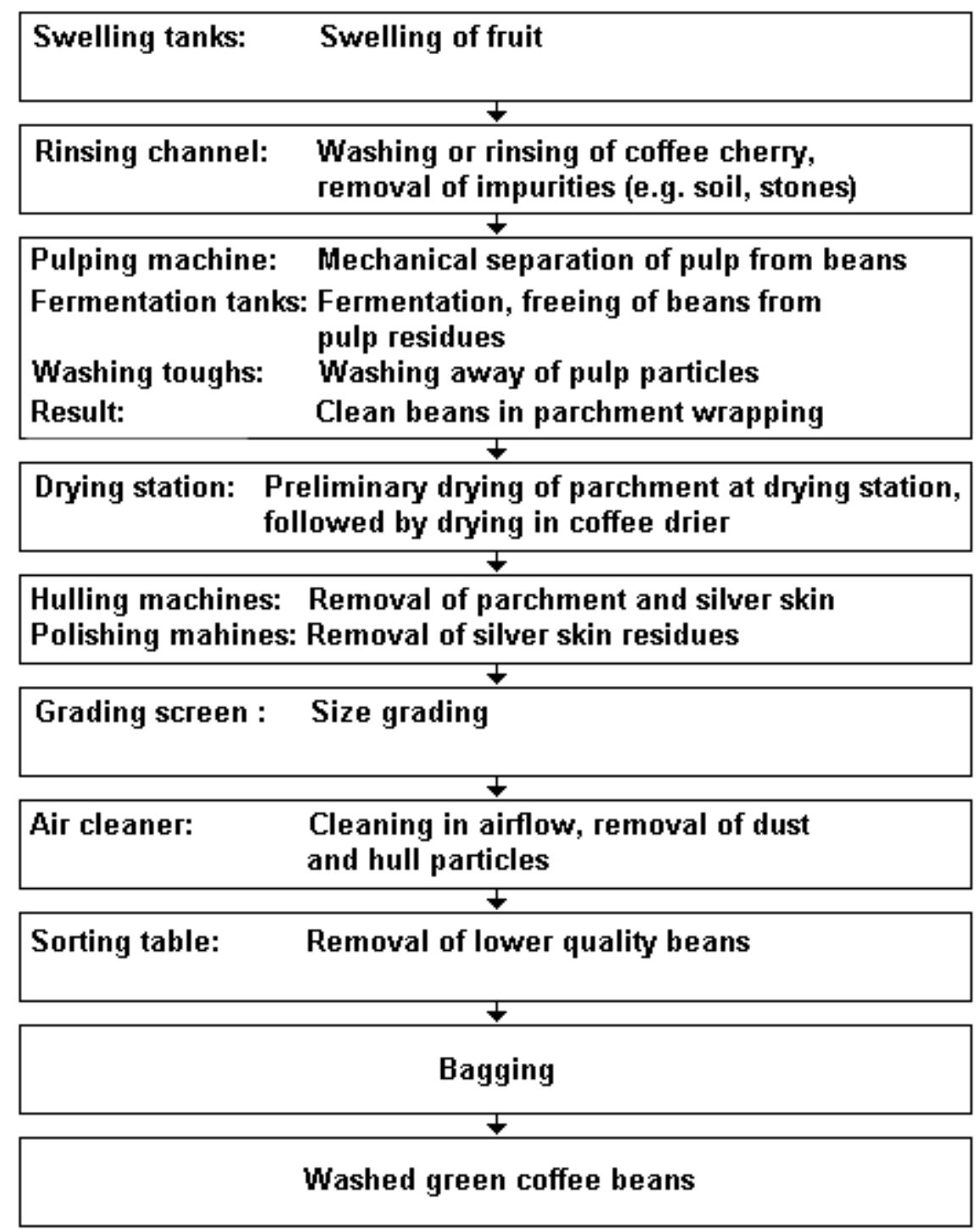

(Transport Information Services N.d.)

A series of different apparatuses - some that shimmy the coffee beans along a conveyor belt, some that blast air at the beans - sift out the misshapen beans. Referred to by evaluators as caracoles (snails), elefantes (elephants), or other specific descriptors, these beans are of insufficient weight as a result of defects, especially coffee diseases such as broca. A supervisor estimated that after this series of evaluations, only about $50 \%$ of the beans are deemed 
suitable for export. Lastly, another conveyor belt carries the beans through an imaging machine that evaluates the beans for color, eliminating those that appear orange- or grey-tinged or marred by other colors.

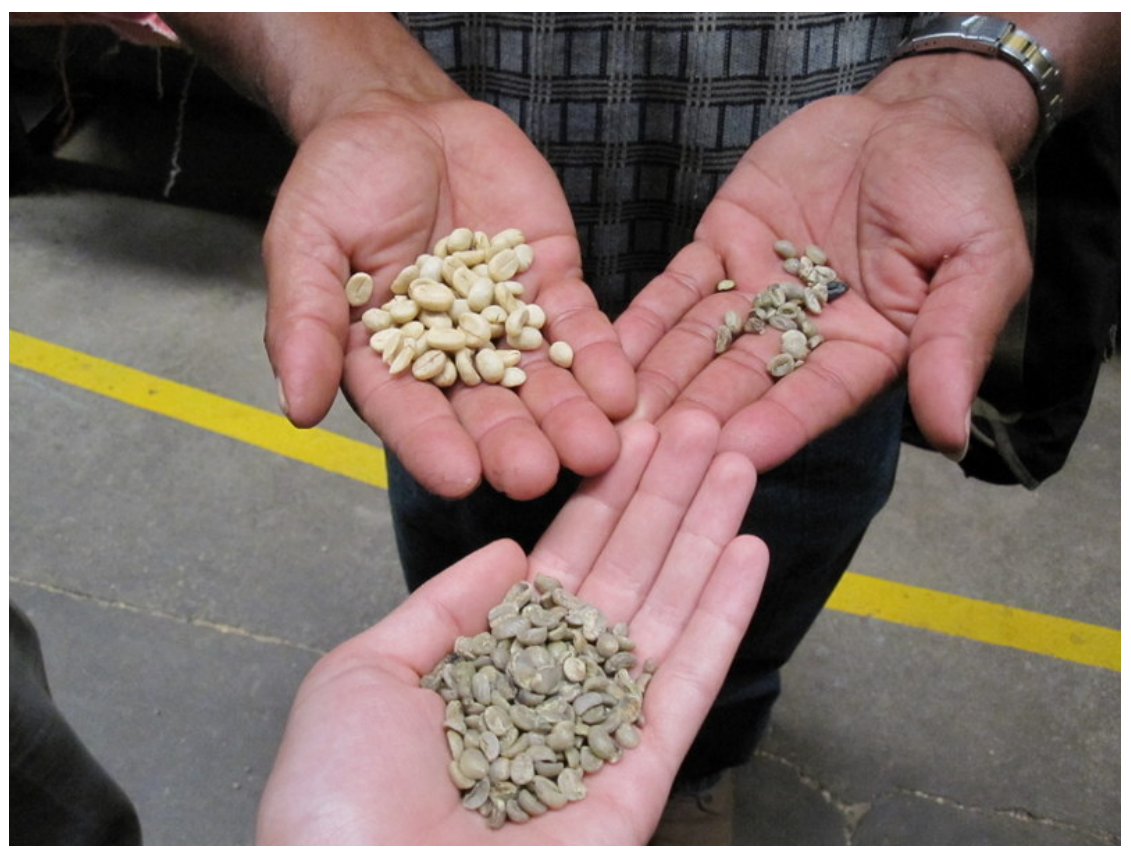

Figure 4.8 Escogiendo (sorting) coffee in the Transcafé bodega: from the upper left café en pergamino, defective coffee beans, café en película

Beyond the bodega, the coffee followed a similar path to market as that of Bella Vista's Grupo Organico. However, nothing is known of La Esperanza's buyer or the final destination of their coffee for that year. La Esperanza participated in the Fair Trade network for only one year before the relationship was terminated. Tense from its inception, Toro Verde was unsettled at La Esperanza's persistence in observing coffee prices. Despite the fact that their contract of sale had already been signed, the cooperative president and the beneficio supervisor continued to call the umbrella cooperative, sometimes after hours and on personal lines, after checking with other purchasers for updated coffee prices in the national market, often reporting on offers from 
conventional buyers and questioning the price Toro Verde would offer. The doggedness of these price inquiries suggested to Toro Verde that La Esperanza did not fully understand the terms of their agreement and might potentially violate the contract in the case of a sufficiently favorable national price.

Toro Verde seemed to anticipate difficulty working with La Esperanza. In an interview that occurred before their relationship was terminated, representatives repeatedly asserted that while they would truly like to maintain the relationship, some aspects, including the organization of the cooperative, were not satisfactory. As a Fair Trade certified organization aimed at improving not just production but also the social organization of cooperatives, Toro Verde strives to maintain "la imagen lo mas sana que es posible" (the cleanest image possible). They strive to partner with cooperatives marked by transparency and democracy in decision-making. In contrast, the recent vote to individualize landholdings grew out of accusations of financial mismanagement and monopolistic control over cooperative planning. Furthermore, individualization raised fears that farmers might not honor the cooperative agreement not to use chemicals in coffee production.

Ultimately, it is unclear which party chose to terminate the relationship, as the former president both claimed that they had been kicked out and declared that they chose to drop out of the producer cooperative network, but the 2009-2010 harvest marked the first and last year that La Esperanza sold coffee through Fair Trade certified channels. According to La Esperanza's 
former president as well as the beneficio supervisor, the cooperative was both unable to meet certain requirements of certification and mistrusting of the umbrella cooperative. Struggles over organic requirements in the beneficio and shade management, including pruning of macadamia trees, contributed to their ejection from the network of Fair Trade producer cooperatives. As one resident explained, "Another change we have made is decontamination of the environment. Because before they contaminated the environment a lot, the woods as well as the rivers. It ended a process that was not very adequate. Perhaps we did not fulfill the requirements, but it was through trainings that we were able to improve this problem, and in this day we have achieved it."

Furthermore, the former president may have posed unwelcome and accusatory questions to representatives of Toro Verde during a meeting of member cooperatives. After attending public lectures on Fair Trade certification given by an outspoken critic and expatriate living in Antigua, Guatemala, the former president was emboldened by this rhetoric which only reinforced the cooperative's existing skepticism. Afterward, it was said that the former president posed aggressive questions in a Toro Verde member meeting, primarily centered on dubious rates for processing and other deductions taken from the coffee price, including wages paid to employees of Toro Verde. According to the beneficio supervisor, the relationship ended because La Esperanza residents did not understand many of the benefits of the Fair Trade system, including prefinancing and access to loans. 
Instead, the cooperative has returned to their former market system, selling to either coyotes who come to the community looking to purchase or to a conventional beneficio, wherever the higher prices can be found. As a result, the commodity chain for this cooperative is the typical conventional market system to which they are accustomed. Interested buyers frequently visit the community, travelling in from the Pacific Coast and staying overnight in the "eco-hotel" where they discuss with cooperative leaders the upcoming harvest and potential price agreements. The community seems more comfor with this system, choosing their purchaser and negotiating their own prices. Though they have no idea the final destination of their product, nor its retail value, they feel they have control over the costs of production and the contracted sale price, which appear to be of greater priority than price stability with a guaranteed purchaser. In fact, this cooperative had the least enthusiasm for guaranteed pricing, with only $41 \%$ of survey respondents preferring a fixed price to a high price, compared with $58 \%$ of residents in Bella Vista and $70 \%$ of Alta Gracia residents.

Unfortunately, it is not possible to compare the economic impact of participation in the Fair Trade system for the single year in which they sold through this commodity chain. Restructuring of land assignments and the cooperative payment system occurred throughout the period in which the cooperative sold coffee as transitional Fair Trade. Like Alta Gracia, La Esperanza received a loan through the Fondo de Tierras to purchase their coffee finca. However, La Esperanza has made efforts to repay the loan, and 
the cooperative has historically held profits collectively, issuing bi-monthly paychecks to residents after deducting a portion for loan repayment. Since the restructuring, the community has gradually shifted away from paychecks, toward paying producers only for the amount of coffee and macadamia they submit to the cooperative, and requiring a quarterly contribution to the loan repayment fund. But this transition has occurred in stages as sections of the finca are divided and assigned through a lottery. As a result, the final price to producers reflects a combination of new land owners receiving full payment for their production and residents still receiving paychecks while they await full rights to produce as individuals. Because paycheck amounts are lower than profits returned to individuals, the final price to producers determined for La Esperanza is believed to be artificially low, and not suitable for an accurate comparison with the other two cooperatives.

\section{HOW MUCH DIFFERENCE CAN IT MAKE?}

The comparison of cooperative commodity chains indicates that Fair Trade certification is, indeed, living up to promises of a higher coffee price. Producers in Bella Vista's Grupo Organico received, on average, $\$ 1.20$ per pound, compared to $\$ 1.08$ in Alta Gracia and $\$ .76$ in the Grupo Convencional. What remains unclear, is how much of this price difference can be attributed to trade through a shorter commodity chain. Following this logic, Alta Gracia's growers should be receiving the highest per-pound price, as they are no longer paying for the services of an umbrella cooperative such as Toro Verde nor do they pay for Fair Trade certification fees. Unfortunately, Alta Gracia's 
production volume has been disappointingly low, failing in the last three years to reach the 125 quintales that they are contracted to sell, instead hovering closer to 90 quintales per year. As their purchaser explained,

Alta Gracia right now, in a great year, and they haven't done this in probably three years, you know they produce a container of coffee. It's a small community, so we're talking 275 sacks. And that's what, like, 40,000 pounds of coffee or something like that? Right? ...But ever since Hurricane Stan [2005], their production has gone down and they're still really trying to recover from that. - Kenneth (interview, September 11, 2009)

Bella Vista, on the other hand, produces more than Alta Gracia in an off-year, lamenting a poor harvest of only 139 quintales of coffee, and more often producing the 400 quintales required to fill a shipping container. In this year's time of low production year, La Esperanza turned in 300 quintales, compared to their usual 600 quintales or more. If Alta Gracia could increase their production volume, the costs of participating in direct export coffee production would be distributed across a greater number of sacks of coffee, leaving producers with a higher final price and a greater portion of the contracted price. Producers had nothing but compliments for the coffee price they receive from their purchaser, but they are unable to reap the benefits.

This year, what happened is that we're doing what is called, I don't know if you will understand this, poda (pruning). Because the coffee trees are really old. So we're planting new ones, getting rid of the old ones. And for that reason, the production has decreased. But we're hoping that with the new plants, in 2013, 2014, we will have better production. For another year it will be low, because the plants still aren't production. It's very little. That's one of the preoccupations. A little bit on the theme that we went to discuss in Boston is "no alcanza." Even though they are paying us a fair price, no alcanza. Food. School. Despite the fair price that we have, we hope that once we have good production, the earnings will support us a little more. Up to now, we are going under. -Francisco (interview, March 11, 2010) 
As this case demonstrates, a shorter commodity chain does not necessarily indicate a better price for coffee growers. Time will tell if efforts at coffee plot renovation will pay off with production increases in the future and if higher production volumes will finally translate into higher final prices. Were Alta Gracia's production volume to rival that of Bella Vista's Grupo Organico, revisiting this comparison would further illustrate the economic difference between coffee sales through certified Fair Trade versus fair trade relationship coffee channels.

Finally, to simply describe a higher price as the "better" price can be misleading. As the next chapter demonstrates, a higher per-pound price is not the be-all-end-all for coffee producers. Fair Trade may offer producers a greater amount of money for the final coffee sale, but the true bottom line costs and gains of sales through a fair trade market system are nearly impossible to calculate. Chipping away at the final coffee price are greater investments of time, relinquished liberties to negotiate in the market, and delayed payments, all of which may be offset by benefits such as environmental preservation and security. How do producers calculate this delicate balance of costs and benefits? How do cooperatives reach the final conclusion that the production and sale of fair trade or conventional coffee is in their best interest? The next chapter examines the dual nature of several hallmarks of fair trade and the nuances that comprise a "better" deal. 


\section{Chapter V: The Bait and Switch}

The advantage in fair trade is that they pay us a fixed price. If the coffee price is low, in fair trade the price never varies. The advantage is that we don't have to worry about 'today the price of coffee dropped, it's ruined'. Our price stays the same. The advantage of sending our coffee to the US is that they give us a premium if we qualify with quality coffee. They give us a premium apart from the price. A stimulus. A small disadvantage is that right now coffee has a good price in the national market. Today we cut coffee, tomorrow we could sell. It's fast. By 4:00 or 5:00 we could sell. But it's a price that doesn't compensate. Francisco (interview, March 11, 2010)

If the decision whether or not to participate in Fair Trade were a simple matter of per-pound coffee price, the decision to pursue certification would be easier for coffee growers to make. And initially it is. When presented with the opportunity to earn more money for their product, coffee growers in Bella Vista and Alta Gracia were eager to join the fair trade network. After a few years' experience, however, reactions to Fair Trade are conflicted. One half of the Bella Vista cooperative and the entire Alta Gracia and La Esperanza cooperatives decided that, for all its benefits, participation in the Fair Trade network was not in their best interests. Even the strongest proponents of in the Grupo Organico question how long they should maintain certification under the current terms of trade.

The simplistic view that producers want a higher price obfuscates a deeper motivation to participate in Fair Trade as a means of harnessing market forces. When producers saw the coffee crisis destroy their economic base and jeopardize the future of their communities, Fair Trade appeared as an opportunity to actively change their entry into the global economy. As one Alta Gracia resident explained, "When we stared coffee, the first years we sold 
in the national market. Twelve years ago the coffee price was incredibly low. We began to look for markets in other countries." It is for this reason that producers so often use the term "preferential market" when discussing the benefits they hoped would result from certification. Instead, what many have experienced is a mind-boggling calculus of hidden costs of certification, missed opportunities, and insulation from the market. Where Fair Trade was seen as a pro-active solution to market unpredictability, many now view it as stifling, confining, and more demanding than the payoff warrants.

While at first glance the decision to join Fair Trade may seem to hold nothing but promise, experience has shown a much more complicated picture, where producers are pressured to prioritize different forms of income, costs, investments of time, and environmental and political values to determine for themselves what constitutes "fair" trade. To better understand the dilemma that producers face in deciding how to participate in the fair trade network, this chapter will examine some of the benefits and drawbacks cited by producers. Frequently, these factors are dual-natured. For example, price stability can be positive when the international price has bottomed out. On the other hand, price stability in a favorable market can leave producers feeling shackled rather than protected. Similarly, factors may be both economic and philosophic in nature, such as the monetary and intangible costs many associate with environmental responsibility. Other factors could not have been fully anticipated or included in the decision to join Fair Trade, such as the rigorous demands of certification requirements. Finally, some of these features are 
characteristic of all forms of fair trade, relationship coffee included, while others are exclusive to certified Fair Trade alone, so effort will be made to distinguish between the two.

\section{THE FAIR TRADE EXPERIENCE, FOR BETTER AND WORSE}

\section{Premiums}

According to FLO, the social premium is, "Money paid on top of the Fair Trade minimum price that is invested in social, environmental and economic developmental projects, decided upon democratically by a committee of producers within the organisation or of workers on a plantation." (Fairtrade Foundation N.d.b) Ideally, this money remains in custody of the cooperative until it can be used to fund a project to benefit the community. In Bella Vista, the social premium has bolstered a number of projects, as one resident explained:

Benefits, yes. For example, in the school it made a restroom, or bathroom. It happened because the premiums support us. A barricade that was made here, a wall, we also supported that with the premiums. The machinery called the secadora (dryer), we saved up to repair that. Yes, yes yes. That's where the premiums go... if there is work in the land, protection, for example the barriers so that the land does not slide, it goes there, too. That's what we do. -Cristóbal (interview, February 2, 2010)

Unfortunately, though the premium has historically provided a great benefit to the community, supporting projects that benefit both cooperative members and the community as a whole, Grupo Organico has lately been unable to use the premiums in the intended manner. Pressured to compete with the favorable prices received by the Grupo Convencional in recent years, 
Grupo Organico members have elected to return premiums directly to producers as an addition to their per-pound rate.

Yes, the FLO premium is also in consideration. The FLO premium, here we have an assembly and agree, in assembly, to use the FLO premium to compensate a little for the price. We add it to the quintal price, over the price of coffee, to the nata [a lower grade coffee], to everything. And if there's some social necessity or diversion or repair to the beneficio here, then we take it out of the sack price. We add the premium to the price. Here is the documentation. Therefore we have to create an act where we declare that the FLO premium will go towards the price of coffee. -Cristóbal (interview, February 2, 2010)

The social premium is a hallmark of Fair Trade certification, but other members in the fair trade network also apply the same concept to their coffee pricing. As mentioned in the previous chapter, Roundtable Roasters adds what they term a "premium" to the per-pound price offered by Cooperative Coffees so that Alta Gracia's final price exceeds $\$ 2.00$ per pound. Unlike Fair Trade, however, the premiums accrued through this market system to do not carry any stipulations for use. As a result, Alta Gracia members, just as Grupo Organico members, have elected to return the premium directly to producers for use at their personal discretion.

\section{Economies of scale}

Coffee is shipped in standard-sized containers of 18,000 kilos, or 39,683 pounds. In order for a cooperative to fill a container independently, they would have to produce at least 400 quintales of export-grade coffee. For small producer cooperatives such as the three examined here, market participation through fair trade channels offers an opportunity to sell to an 
export market that would otherwise be closed and security to maintain trade agreements.

Alta Gracia currently struggles to fill a contract for 125 quintales of coffee, and last year La Esperanza deposited 300 quintales, of which perhaps only $50 \%$ will make the export grade. Bella Vista may, in a good year, produce a sufficient quantity to fill a container, as in the $2009-2010$ harvest. The preceding year, however, heavy winds decimated budding coffee flowers in February and March, so that the cooperative barely produced 139 quintales for export. Participation in an umbrella cooperative such as Toro Verde provides security so that, in the inevitable event that production volumes drop, quantities can be combined with other cooperatives to fill a container.

... For now, getting half a container of coffee from Guatemala to the United States is really hard. And if they [Alta Gracia] could double that, which they easily can with the amount of the land they have? Oh my god, they should be producing two or three. But they just don't. You know down in Oro Verde [another producer cooperative] they're these people, this community, smaller than them that are just whooping their butts in quantity. So anyways, basically what had they do to last year was find another cooperative to combine their coffee and then ship it in one container since you can't just ship a half a container. So logistically that was a huge nightmare for Cooperative Coffees to deal with. So for me, they really have to get that quantity up and they can do it, but I think some training would be helpful. -Jamie (interview, September 15, 2009)

Additionally, collaboration with other cooperatives can provide a price advantage. Producer cooperatives share the cost of an export license, paying a portion rather than the prohibitive total cost Information sharing allows producers to demand better prices and decline unfavorable offers. As Darrell (interview, September 10, 2009) of Roundtable Roasters explains: 
There's a lot to examine and a lot to understand about how Alta Gracia participates internationally. That's one of the things for coffee farmers is that they don't really know how coffee gets values, so the coyote comes to them, says, "This is this year's price, take it or leave it." They can't really leave it, so they take it. And you know you're in a disadvantaged place in the marketplace, so being a coop allows them to get information. They can learn where to get that information, then empower themselves to say 'no' to certain prices, or say, "This year we'd like a little more", you know, things like that, which they say to us [laughs]...

Furthermore, by offering a larger volume of coffee than possible as individual producers, the cooperatives can contract for a higher price. One member of Grupo Organico stated, "We are going to have advantages in our volume for export," followed by another member's affirmation, "In the price." Yet another member concurred, "It would be a mistake if we had to disintegrate [the cooperative]. Individualized, it would be the coyote who would buy, we would sell our product at a lower price, and the advantage would be for the coyote... so if we do this, join ourselves with other organizations like Toro Verde, then globally we produce a good quantity to supply the market."

While economies of scale may provide security by enabling producers to ship even small quantities of coffee, they also burden producers with dependence on other actors in the commodity chain. Integration into other cooperatives' supply chain additionally brings slower payment, less direct contact with buyers, and contracts that can also be viewed as both a blessing and a curse, all features to be discussed in greater detail below. 


\section{Price stability}

When first introduced in Bella Vista and Alta Gracia in the early 2000s as a solution to erratic market prices, the Fair Trade and organic certification offered a significant price advantage over conventional market sales. Coffee producers worldwide received record low prices in 1992 as the New York Coffee Exchange hit a record low. In the following years, reports of frosts, droughts, and other natural disasters set prices to rebound again, and in 1997 producers enjoyed new highs as coffee hit a peak price of $\$ 2.50$ per pound, only to fall careening again to record lows in the early 2000s. Meanwhile, Fair Trade offered a fixed minimum price of $\$ 1.40$ per pound as well as a $\$ .50$ per pound premium, for a total of $\$ 1.90$ per pound before deductions. As one Bella Vista resident explained, "Well, the prices drop and come way down. In fair trade it has to be decided a limit where it cannot come down below. It is one of the advantages because if the price of coffee drops, in fair trade it stays, it cannot drop any lower." (Eugenio, interview, January 23, 2010)

Table 5.1 Average price paid to growers (In Current Terms) Calendar years 2000 to 2010 (US cents per lb)

\begin{tabular}{|l|l|l|l|l|l|l|l|l|l|l|l|}
\hline Country & $\mathbf{0 0}$ & $\mathbf{0 1}$ & $\mathbf{0 2}$ & $\mathbf{0 3}$ & $\mathbf{0 4}$ & $\mathbf{0 5}$ & $\mathbf{0 6}$ & $\mathbf{0 7}$ & $\mathbf{0 8}$ & $\mathbf{0 9}$ & $\mathbf{1 0}$ \\
\hline Colombia & 74.96 & 57.7 & 52. & $\mathbf{4 8 . 3}$ & 60.8 & 89.2 & 89. & 100. & 114. & 138. & 180.55 \\
& & 7 & 43 & 4 & 3 & 2 & 81 & 05 & 22 & 56 & \\
\hline El Salvador & 44.55 & 17.6 & 21. & 25.6 & 39.3 & 67.1 & 67. & 75.2 & 86.0 & 79.1 & 109.88 \\
& & 3 & 84 & 9 & 0 & 0 & 49 & 4 & 5 & 9 & \\
\hline Guatemala & 70.37 & 45.3 & 49. & 48.4 & 66.9 & 92.4 & 91. & 98.2 & 111. & 109. & 144.75 \\
& & 4 & 61 & 2 & 1 & 6 & 19 & 8 & 03 & 63 & \\
\hline Honduras & 54.29 & 34.3 & 37. & 41.7 & 50.2 & 78.7 & 80. & 81.6 & 90.6 & 83.6 & 125.13 \\
& & 2 & 06 & 3 & 8 & 6 & 82 & 3 & 1 & 9 & \\
\hline Mexico & 64.08 & 53.9 & 43. & 64.0 & 90.7 & 139. & 85. & 90.9 & 106. & & \\
& & 8 & 02 & 2 & 8 & 03 & 50 & 1 & 05 & & \\
\hline
\end{tabular}

(ICO N.d.) 
In 2005 , however, coffee prices once again broached the $\$ 1.00$ per pound mark, steadily lessening the differential between conventional and certified sales, and, for many in Bella Vista, raising doubts about whether or not certification was a worthwhile endeavor. Enthusiasm for Fair Trade has begun to waver, even among its most outspoken proponents. One member of Grupo Organico explained, "So in the beginning, I think it was really good. Fair trade for us, we had a secure product price. But over the course of the years, Fair Trade has stayed here and the national prices have gone up... staying only with Fair Trade, we stay below and the conventional prices are taking off." (Cristóbal, interview, February 2, 2010)

Much as Fair Trade Federation members criticize FLO for never adjusting its minimum price for inflation, producers also resent the failure of Fair Trade pricing to react to the international market. Fair Trade is intended to function precisely as a foil to wild up- and downswings in the $\mathrm{C}$ price, providing income stability to producers who are ill-prepared to capitalize on price speculation. However, for producers, the minimum price that once served as a lifebuoy now functions more as shackles.

For years he has bought our coffee, he has come here to Bella Vista, and so he says, "Fine, Bella Vista, it's a deal, I will pay you the best price," but with fair trade, because the prices go up and they give us a price more than fair trade to compensate for everything that is happening in the business of coffee. Because it is really variable, the movement of this business, so fair trade is then left behind, right? I don't know what is going to happen if, in case coffee goes back to how it was in 2002, 2004 or so. We were in fair trade and nothing happened to us, right? Coffee, according to the information, when there's a deal it has a techo [ceiling], right? It cannot pass here and neither can the buyer, he cannot give more. So this is where we are left, and although we would like more, it is not possible. But he has worked with us on a 
price in accordance with the cost of our product, right? So, fair trade is good because, what I have seen is that the price is secure, right? The coffee price goes down and we are safe here. The problem is when the price goes up and fair trade does not pass it because there is a ceiling. It is a little bit of a problem in these last three years. The last three years. But we, with real training, we have understood. We hope, as members or as organizations like the eleven organizations in Toro Verde, we hope that this will improve. We will see if it can raise a little. Cristóbal (interview, February 2, 2010)

On the other hand, in the form of fair trade in which Alta Gracia engages, purchasers not only allow growers to contact them directly in request of price increases, but also make efforts to adjust their price for inflation and increases in the cost of living. As Kenneth (interview, September 11, 2009) of

Roundtable Roasters explained:

He's [cooperative president] had other coffee roasters come and build some sort of relationship with them and try to, probably fairly innocently, try to buy the coffee out from under Roundtable Roasters. And whenever Benigno tells them how much we're paying, they are always like, he said one just was just like, "That's insane. That's actually insane. You know, we're willing to donate something to you, or we'll give you a grant, or we'll give you some (in my mind) some charity, but we're not gonna pay you what your coffee should be worth." Or, "We're not going to pay you all for your labor." And I just think it's ridiculous. So that's one of our goals, is to continue to pay some of the highest prices that are being paid in Guatemala. So this year [2009] we're paying $\$ 2.15$ a pound, which is about 60 cents, a little but more than 60 cents above the Fair Trade minimum, I think. So it's substantially higher. We wanna keep pushing that up and not have the price become static, which is a criticism we've had of the Fair Trade pricing, is that the minimum pricing has been so static for so long while growers, all of their costs have gone up, both production costs and certification costs as well. Just the general breadbasket, you know, everything - medical, access to medicine, access to education for their kids. And so that's really important. 


\section{Guaranteed buyer}

A "key objective" of Fair Trade is to "facilitate long-term trading partnerships and enable greater producer control over the trading process." (Fairtrade International N.d.) This feature is intended to further increase the predictability of trade for producers, eliminating the uncertainty of finding a purchaser and estimating annual income from coffee sales. Additionally, many members of the fair trade network stress the importance of long-term relationships in accomplishing development goals in producer communities. However skepticism of both the efficacy and wisdom of a guaranteed buyer lies in both ends of the commodity chain.

For their part, some fair trade roasters, such as Dean Cycon of Dean's Beans, questioned whether certification organizations such as FLO place sufficient emphasis on this feature. Similarly, Kenneth (interview, September 11, 2009) of Roundtable Roasters raised concerns that producer/purchaser relationships are neglected in the FLO-certified market system.

Any roaster can go to source and meet a grower cooperative, and if they're certified they can contract with another importer to buy their coffee. But what most - many, I don't know if most is correct - but many roasters who are selling fair trade coffee, what they do is they just call a commercial importer. They read what Fair Trade certified, FLO certified coffees are available on the menu and then they order them. And they get them delivered and there's no contact between buyer and grower, the roaster and the grower. And that isn't, I don't think that's consistent with what the idea of fair trade is. And I think that it's problematic, if you get on Transfair's website and read about what fair trade is, how that transaction goes down, I don't think really jibes sometimes with that.

In the case of Alta Gracia, a guaranteed buyer such as Roundtable

Roasters has been beneficial to the community, both socially and 
economically. Roundtable Roasters has purchased Alta Gracia's coffee since 2003 , and a great benefit of this relationship has been the relative ease with which members of both organizations can communicate their needs and expectations. Alta Gracia receives bi- or tri-annual payments for their coffee harvest, at least once in advance of the final sale, and because of their frequent contact with their buyer they can anticipate the amount and the time of payment. In the aftermath of Hurricane Stan, which battered coffee plants and demolished the majority of Alta Gracia's coffee production for the year, the Roundtable Roasters organized fundraisers to support the community in absence of their primary source of income. Furthermore, their ongoing relationship affords Roundtable Roasters insight into the development objectives of the community and allows them to facilitate contact with organizations that can provide the development support they need.

In the case of Bella Vista's Grupo Organico, on the other hand, though they have sold to the same purchaser for the last several years, they are less acquainted with their buyer compared to Alta Gracia. Rather than find comfort in the stability of this relationship, Grupo Organico members felt locked into terms of trade that appeared less favorable by the day. In contrast with Alta Gracia, Grupo Organico members do not have direct communication with their purchaser, so some of the benefits of a long-term purchasing agreement are lost. It is not possible to request additional financing for community development projects, nor is it even permissible for them to contact the purchaser directly for a higher price to remain competitive with the 
conventional price. Instead, Grupo Organico members rely on their umbrella cooperative to facilitate this communication, while they await with bated breath the news whether or not their purchaser will raise his price.

Now we're going to have a meeting for the Don's [the purchaser] visit. We will see in the meeting that they [Grupo Organico members] are worried about the prices that will come. But there should already be a set price, so then, today, this meeting is going to be about, well, upon hearing it, they are going to be happy or going to leave sad, no one knows. Right now it's a secret that we don't know either because there has not been any information until it leaves the warehouse... - Cristóbal (interview, February 2, 2010)

While a guaranteed buyer was expected to benefit producers by easing the stress of uncertain terms of trade, it seems that in this case producers are actually more anxious about the final price they will receive. As they watch rising conventional prices and a diminishing price advantage despite their participation in a "preferred market," producers in Grupo Organico often feel less in control, again at the mercy of the market, as they are powerless to take advantage of price changes. This suggests that long-term Fair Trade relationships, if not accompanied by frequent communication with the purchaser, may not be benefitting producers as anticipated, leaving them less at liberty to dictate how they participate in negotiations with purchasers.

Sellers in the conventional market, on the other hand, are able to take advantage of price fluctuations in a favorable market. In a conventional cooperative, once a sufficient quantity of coffee is amassed, members can begin voting on whether or not to sell. If prices are favorable, the cooperative may elect to sell everything available at the moment to ensure at least a portion of the harvest garners a good price. If the prices are unfavorable or 
expected to continue rising, the cooperative may elect to stockpile their supply while keeping an eye on price changes. As one Grupo Convencional member explained, "When it's just cut, we sell it. We count it and sell it, according to the price. If it's a good price, we sell. If not, no. When it goes up we sell." (Ezequiel, interview, February 25, 2010). This is seen as one of the primary draws of the conventional system, even in the eyes of members of Grupo Organico: "The advantage is that with the way they dry coffee, if there's a good price, they sell. [That] more than anything, I say." (Catalina, interview, February 20, 2010)

To cooperative members, this form of commercialization affords more control over profits. But it can also be risky: “I don't know if you have noticed that sometimes there's a good price and the people wait, because they think it will go up more, and in the end they lose." (Catalina, interview, February 20, 2010) But Grupo Convencional members talk of fluctuating prices as a fact of life. As one resident explained, "Yes, prices drop and rise. That's how the prices go. This year the price was good. 900. 850. It was nice." (Ezequiel, interview, February 25, 2010) Other group members concur, stating "We always act in accordance with the prices discussed in the beneficios [in nearby cities]. This year was a good year because the coffee sold at, the lowest price, 800. The rest we sold for a little more, 900 . So this is one of the advantages that we have. If prices go up, we earn more. And if prices go down, we lose." (Ovidio, interview, February 21, 2010). These sentiments were echoed by a member of Grupo Convencional, who explained, 
Yes, for 9[00] or 8[00], yes. But I don't know if it's going to stay there or not. It's isn't known. But there are years when it comes to 400, 500. It goes down. So we say in organic there is an advantage but there is also a disadvantage. Same as conventional. There are advantages and disadvantages. When we are lucky, the coffee price goes up. But there are years when it comes down, too. -Efrain (interview, February 4, 2010)

Fair Trade and organic certification were presented to the community as a means of capturing higher prices for coffee and securing a good price in years when the international market bottomed out. But in the case of favorable market conditions, what was once seen as security in Fair Trade is now viewed more as a constraint to market participation. The fixed nature of the FLO price is especially problematic for producers in Bella Vista and La Esperanza, both of which have experience selling coffee in the conventional market and are accustomed to monitoring market prices for themselves, evaluating price advantages, and weathering market turbulence. Fair Trade, which was initially treated as a pro-active effort to leverage a price advantage, now appears to restrict producer options for market participation.

The payment schedule

As an annually harvested crop, coffee earnings are typically only collected in a window of a couple months per year. Selling as a cooperative further narrows this window, as the coffee shipment and payment must be coordinated across all producer cooperatives. As a result, though the harvest typically ends in December and deliveries to the bodega are completed in January, the coffee is not likely to leave Guatemala until February or March. The shipment must then be received by the foreign importer and re-evaluated 
for quality. As a result, a primary drawback for producers in any form of fair trade network is the lag between the day coffee leaves the farm and the day the final payment is received.

But because we are poor, we don't have money, so with Fair Trade it goes for a good price, but the money doesn't come right away... so there was a group of 50 people, we separated and left from [Grupo] Organico... we left because we sell our coffee at the national level here in Guatemala and then the money comes. The money comes sooner. And in Organico it's later. It comes much slower. For us, because we want our money right away, that's how it came about that we sell here in Guatemala... our Organico partners export. They export. It leaves. And that is why we left the group. -Efrain (interview, February 4, 2010)

One's willingness to accept delayed payment is in part a matter of alternate sources of income. Some producers feel pressured to violate contract requirements and sell coffee outside the cooperative. Others are able to mitigate this delay with income received from other forms of employment. In such situations, coffee income is usually spent on major expenses, especially reinvestment in coffee. Meanwhile, income earned from outside employment is used to cover regular household expenses, such as food, clothing, education, and medicines.

Yes, all the families who turn in their coffee, we've exported it. There's a small problem with that. Some families, out of necessity, have had to sell a little coffee in the local market because sometimes there's no money... It's difficult to wait. And the harvest ended in December. And the coffee hasn't left yet. And we don't have any more. And the money isn't really a lot because there wasn't a lot of coffee. Really, I don't know how people do it here, how they survive. Because I work in Guate[mala City]. - Rodolfo (interview, March 15, 2010)

But not all producers, nor all communities, are equally prepared for outside employment. Several factors can influence availability of jobs, particularly accessibility and education, are unevenly distributed both across 
and within communities. As Ciriaco (interview, March 8, 2010) of Alta Gracia explained,

The difference is that I have the possibility to work afuera (outside). And 4-5 years I have been working outside. Because some neighbors have not been able to work outside, because their education level is really low. Including security, you need a curriculum. You need letters of recommendation. You need to be in accordance with the law, no problems with the law, a clean record. This and work experience are what help you get work. If you don't have it, some have had to stay here because of these limitations. That's why we are not all at the same level... Last year I recommended a neighbor so that he could get a job where I work, but what was his limitation? He couldn't read. Every day I have to make a report of my shift - what happened, what didn't. And that was his problem. He couldn't read to do it. So, obviously you need a diploma. So he was left without work.

In Alta Gracia, $50 \%$ of those surveyed reported having some form of additional employment, compared with $32 \%$ in Bella Vista and $26 \%$ in La Esperanza. However, according to the informant quoted above, only 5-6 Alta Gracia residents engage in outside employment. The disparity between his estimate and survey findings is likely due to a difference in the nature of employment, with work afuera indicating dependable, consistent employment that provides a paycheck and carries education requirements, positions such as public health worker, teacher, security guard, or government worker. In addition to employment afuera, survey respondents also reported engaging in other forms of employment, less consistent and paid on a daily or perassignment basis, in order to earn money for household expenses. These positions include construction worker, bus driver, and day laborer. Still other income-earning strategies, such as shop owner and employees of cooperative projects such as the beneficio crew and tostaduría worker, are based within 
the community and depend on the financial support of other residents. So while only 5-6 residents in the most employed community are engaged in dependable, off-farm employment, many other residents still participate in what they consider to be supplementary income-earning activities.

The three cooperatives are differentially prepared for employment afuera, with $83 \%$ of Alta Gracia residents reporting that they had attended some school, compared with $63 \%$ of residents in both Bella Vista and La Esperanza. Alta Gracia residents who attended some school also reported a higher average level of education of 9 years of schooling, or completion of high school level education. This is in stark contrast with Bella Vista residents who reported an average of 6 years of schooling, the equivalent of completion of junior high school, and La Esperanza residents who averaged 3 years of school, providing basic literacy and computational skills. Looking more closely at the case of Bella Vista's two separate cooperatives, $50 \%$ of the surveyed members of Grupo Organico reported having some type of employment other than coffee cultivation, while only $17 \%$ of Grupo Convencional responded in kind. Surveyed members of Grupo Organico also reported higher levels of education, with $81 \%$ having attended some school, compared with $50 \%$ in Grupo Convencional, and an average education level of 6 years of school, compared with 3 years in the other cooperative.

These contrasts indicate that in Alta Gracia, where residents are both more likely to have an additional form of employment and better prepared for reliable work afuera, producers are better equipped with income opportunities 
to tide them over until the coffee payments arrive. Similarly, Bella Vista residents who have elected to return to the conventional market system appear to have lower levels of education, hence fewer opportunities for outside employment, and engage less in supplementary income-earning activities. Furthermore, absence of supplementary employment is one of the reasons most frequently cited by the few community residents who opt not to participate in any cooperative. This suggests that availability of an auxiliary income-earning strategy is a distinguishing characteristic of those who are better-suited for participation in a non-conventional market system.

\section{Prestamos}

In the absence of auxiliary employment, another option for weathering delayed payment is the prefinancing option, wherein producers receive from purchasers a portion of their anticipated coffee income prior to the final coffee sale. Another hallmark of Fair Trade, FLO explains the importance of prefinancing in its requirements for certified purchasers as follows: "Fair Trade Standards require buyers to give a financial advance on contracts, called prefinancing, if producers ask for it. This is to help producers to have access to capital and so overcome what can be one of the biggest obstacles to their development. This promotes entrepreneurship and can assist the economic development of entire rural communities." (Fairtrade International N.d.)

While prefinancing extends to producers an opportunity for credit that would otherwise be inaccessible in the absence of collateral, it usually also carries interest charges. Though considered blando (mild) and lower than 
would be offered in other lending institutions, even at a rate of $9 \%$ as offered by Toro Verde, interest charges erode upcoming coffee profits. The fair trade system in which Alta Gracia participates also offers a prefinancing option, though their purchasers are actively looking for means of shifting the burden of interest payments away from producers. Furthermore, though Fair Trade standards require purchasers to make a prefinancing option available, it has not always been made convenient for producers. These factors render prefinancing a less practical solution than anticipated. As a representative of Roundtable Roasters explains:

One of the main pieces of FT [fair trade] is the commitment of buyers to "pre-finance" purchases with grower groups. In the past this was routinely downplayed as technically it is up to the grower groups to ask buyers for credit. That created a neat loophole as many producer groups were less than strident about asking for advances for fear of alienating buyers who, at the time, were paying significantly more for their coffee. Grower groups also often attempted to squeak by without pre-financing because they normally have been responsible for paying the interest on these transactions which effectively lessened the already insufficient price that they received for their coffee in the end. (Earley 2011)

All three cooperatives in this study have taken advantage of the prefinancing option, though to different ends. In Bella Vista, producers frequently reported taking out prestamos, or loans, to invest in renovation of their coffee plots. In La Esperanza's single year of participation in the Toro Verde network, the community took out a prestamo to make a payment on their Fondo de Tierras loan. Alta Gracia producers, on the other hand, often used their loans to pay for hired laborers to work their coffee throughout the year. 
This money more than anything we use it for work in the coffee plot. When the harvest is over the work begins. And it has to be punctual. First is the weeding. Then el descombro (trimming the shade trees). You have to cut the branches when there's too much sombra (shade). Then it's the poda (pruning). Poda selectiva y la recepa (two pruning techniques). They're different. You have to do them in the first months of the year. You can't wait until June, July. No. you have to do them in these months [March]. Because by February it's already started espigar (to grow branches). The flowers have already come. So you have to descombra first. It can't be floreando (flowering) when you start cutting or you'll lose the fruit. -Ciriaco (interview, March 8, 2010)

Prefinancing, then, is another example of a dual-natured feature of fair

trade. It can be viewed as both a benefit, offering producers an opportunity they would not otherwise be granted, as well as a drawback, chipping away at the already meager earning producers are bound to receive. Moreover, prefinancing can be seen as remedy to a situation created by virtue of one's participation in the system. Fair trade permits producers to borrow throughout the year, but is it often used to cover costs generated by the system (increased labor and input costs) and cope with delayed payment that is characteristic of the system, and it ultimately generates additional costs in the form of interest payments. For this reason, the few producers who opt not to participate in any grower cooperative view this feature of the fair trade system as a vicious cycle from which they have abstained.

\section{Hidden costs of certified production}

As indicated above, many producers understand their contract price as a techo, a ceiling, a limit rather than a minimum. The perception of a price limit is especially problematic in the case of Bella Vista, where Grupo Organico members are daily faced with the alternate scenario pursued by those who 
have opted not to sell through Fair Trade channels. Beyond potential interest charges and the lost opportunity to capitalize on rising coffee prices, selling through a fair trade market system comes at an additional cost in the form of labor requirements. With international market prices as high as $\$ 1.44$ in 2010 , and Grupo Convencional members reportedly selling for per-pound prices comparable to that of the Grupo Organico, it is no wonder that producers are questioning how much a market advantage all their extra efforts are earning.

It was hard for us to be in compliance with the organic organization, people taught us how to work, but we noticed at the very start, you have to work really hard... We weren't able to stay with the organic plan. It was hard... So we started thinking, it's a lot of work and the coffee price [national] was good, so there was no advantage. So that's how the ideas started coming out, disagreements. We couldn't buy plants because the chemicals and the nursery didn't work. That's how we organized 50 people to leave the organic project. We divided. -Martín, interview, February 24, 2010

As this Grupo Convencional member explains, production in accordance with Fair Trade and organic certification requirements is complicated, time-consuming, and carefully regimented. Though at first glance the guidelines appear sufficiently demanding to prescribe the conduct of each stage of production, from the planting of saplings to the final coffee delivery, the effect is more complicated than a few simple changes in cultivation technique. Certified growing practices are more labor-intensive, demanding a greater investment of time and/or money for their completion. For example, organic certification dictates that producers plant only organic seedlings, which are more expensive than conventional seedlings and produced at a limited number of nurseries, so they often accrue greater transport costs. To plant 
seedlings, certified producers must dig deeper and wider holes than their conventional counterparts, increasing the time spent to complete the task and again augmenting the cost of production, either in terms of time detracted from other activities or more days of paid labor. Fertilizer application, perhaps most challenging of all requirements, will be discussed in more detail below.

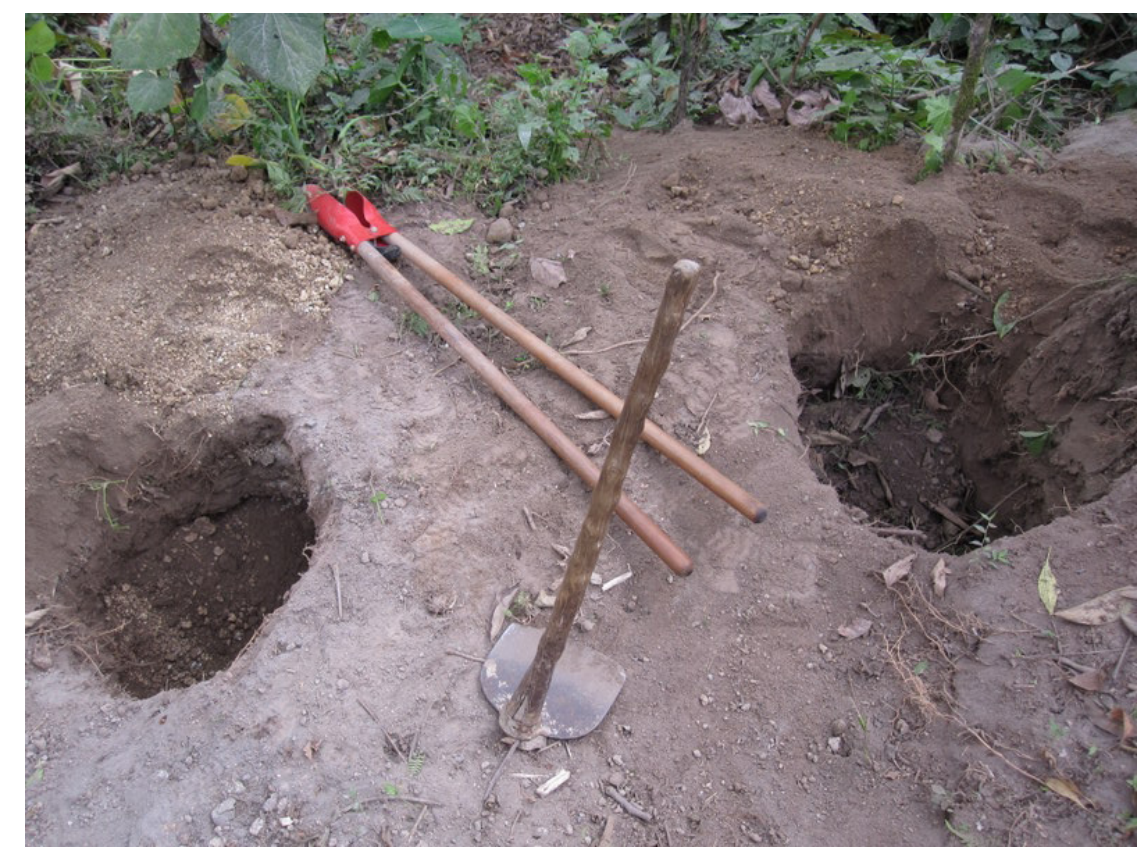

Figure 5.1 Preparation for planting: holes of regulation depth and width to be filled with organic fertilizer

To ensure quality and maximum production, certification requirements also dictate the schedule of cultivation activities, from planting to weeding to pruning to picking. Most disruptive to producers' customary work pattern is the picking schedule. Left to their own devices, the consensus seems to be in favor of passing over a coffee plot every 15 days to pick the ripest red cherries as well as the moderately ripe orange or yellow cherries, which will only continue to mature to the point of drying on the tree between rounds of picking. Certification requirements, however, prohibit this practice, instead 
declaring that producers should only pick the ripest red cherries off the tree and return to pass over the same area frequently to make sure they are picked at prime ripeness. Such careful selection significantly increases the time or money spent on the coffee plot during harvest season. As one producer explained, when picking is limited to only red cherries, a smaller volume can be collected during each pass through the coffee plot. In the event that the amount of ripe cherries is less than a quintal, laborers must be paid by the day instead. Since the pay rate is about equal, around $40 Q$ per day or per quintal, producers spend the same amount of money for less progress made in the coffee harvest.

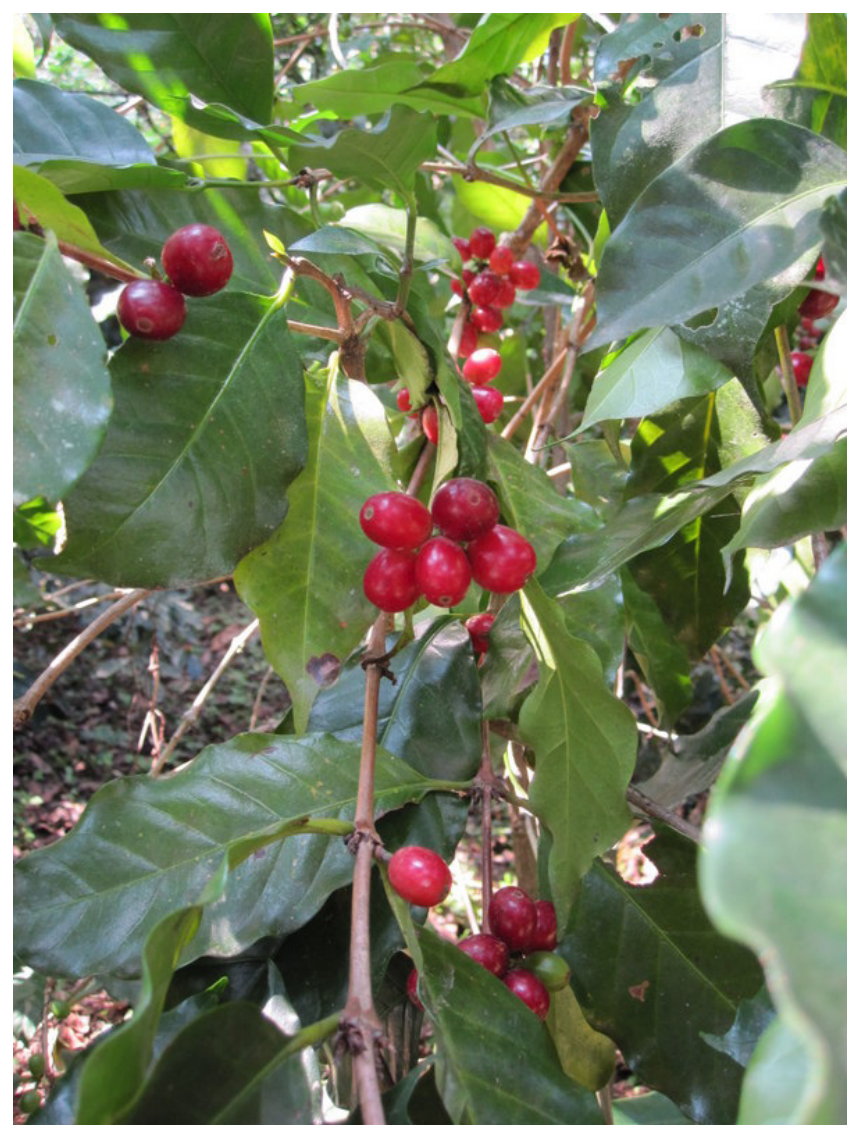

Figure 5.2a Selección (choosing cherries) in the fields: perfectly rojo (red) and maduro (ripe) coffee cherries 


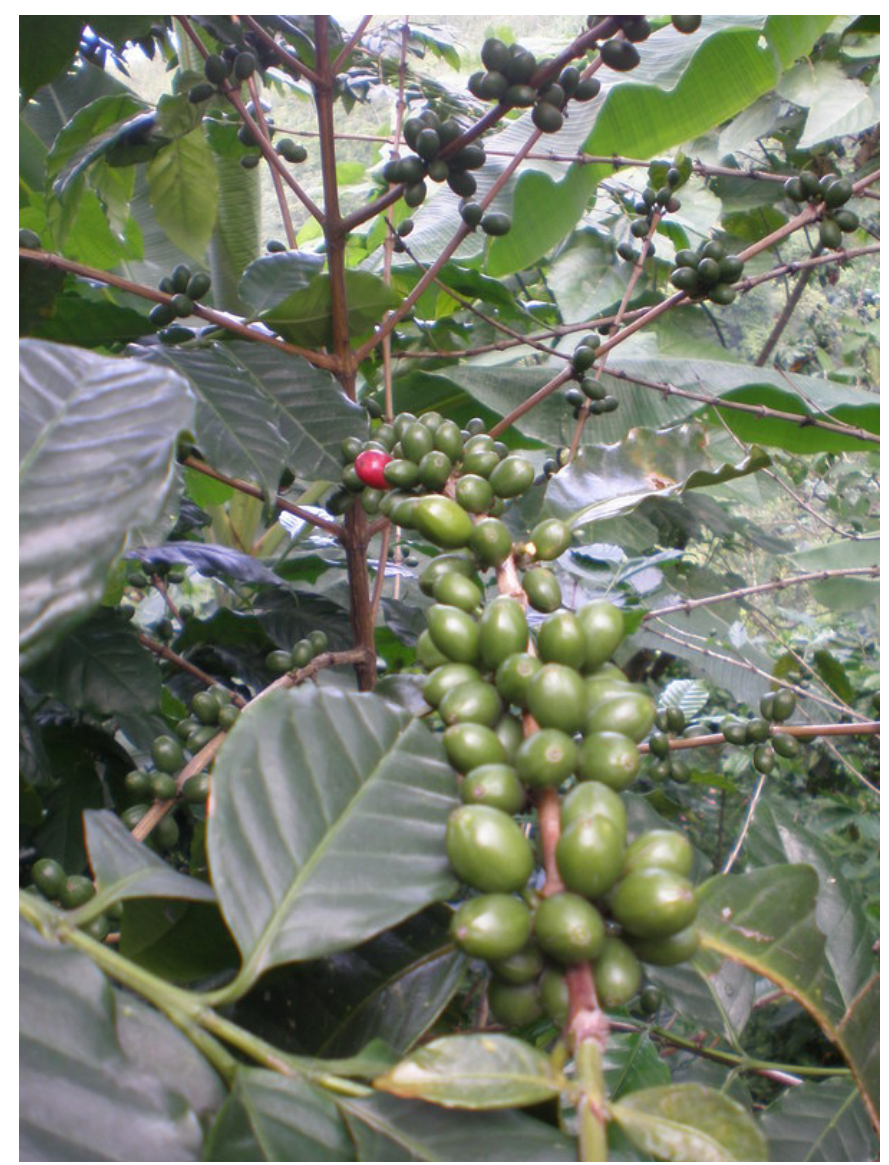

Figure 5.2b Selección in the fields: verde (unripe) coffee cherries save one singular rojito

Additionally, certified producers are required to maintain a log of their cultivation activities, which can be evaluated by inspectors during their annual visit.

It requires a lot of patience to work with so many documents, and the people, too, are bothered by the fact that they have to carry around their register, "What did I do today?" Well, today I went to work in the land. I was weeding or I was pruning or I cut something down or I applied fertilizer, everything has to be noted. It's a lot of work, and it's hard, but we want a good price, right? So we have to do it. Our issue last year with Mayacert [organic certifying agency] was the registries. "You have your work calendar?" "Ah, no, I didn't bring it." "And him?" "Let me look..." "Give me your calendar, then." "Here is it." "Very well then. January. February. March. April. Everything is documented. Mmhmm..." - Cristóbal (interview, February 2, 2010) 
In the case of Alta Gracia, though they do not participate in certified Fair Trade, they are still required by their purchasers to maintain organic certification. Moreover, demands are still made on the quality of the coffee product, which requires a greater investment of time for control in cultivation and processing. As a result, they, too, must comply with the organic requirements for cultivation and picking practices. However, since the overwhelming majority of Alta Gracia residents had no experience working in coffee prior to settlement, they had little cultivation or growing customs outside the demands of them by certification requirements. Therefore, there was much less resentment of work calendars and labor registries in this cooperative. On the contrary, one resident eagerly shared the record he kept for paid labor he carried for another cooperative member in the $2009-2010$ harvest cycle: 
Figure 5.4 Work registro of Don Lorenzo

\begin{tabular}{|c|c|c|c|c|c|}
\hline 2009 & & & $\begin{array}{l}\text { Jornales } \\
\text { (wage unit } \\
\text { accrued per- } \\
\text { task) }\end{array}$ & $\begin{array}{l}\text { Pay } \\
\text { rate per } \\
\text { jornal }\end{array}$ & Earnings \\
\hline \multirow{4}{*}{ April } & $1-5$ & Limpia (weeding) & 10 & $25 \mathrm{Q}$ & 250 \\
\hline & $6-10$ & $\begin{array}{l}\text { Arrancar troncos (uprooting stumps } \\
\text { of old coffee plants) }\end{array}$ & 10 & 50 & 500 \\
\hline & $11-15$ & Recojer troncos (removing stumps) & 4 & 40 & 160 \\
\hline & $20-30$ & $\begin{array}{l}\text { Aroyado [sic] para café (digging } \\
\text { holes for coffee plants) }\end{array}$ & 14 & 40 & 560 \\
\hline \multirow[t]{3}{*}{ Mayo } & 4 & $\begin{array}{l}\text { Abono acarreo almácigo (carrying } \\
\text { fertilizer from the nursery) }\end{array}$ & 4 & 40 & 160 \\
\hline & $5-9$ & Riego de abono (applying fertilizer) & 4 & 40 & 160 \\
\hline & $10-22$ & $\begin{array}{l}\text { Siembra almácigo (planting } \\
\text { seedlings) }\end{array}$ & 12 & 40 & 480 \\
\hline Junio & $20-25$ & Limpia & 5 & 40 & 200 \\
\hline Agosto & $20-25$ & $\begin{array}{l}\text { Cajetiado [sic] (assorted } \\
\text { maintenance) }\end{array}$ & 5 & 40 & 200 \\
\hline Oct & $17-22$ & Limpia & 5 & 40 & 200 \\
\hline \multirow[t]{2}{*}{ Dec } & $17-22$ & Cajetiado & 5 & 40 & 200 \\
\hline & & & & & 3070 \\
\hline \multicolumn{6}{|l|}{2010} \\
\hline Feb & $22-27$ & Limpia & 5 & 40 & 200 \\
\hline Abril & $20-25$ & Cajetiado & 5 & 40 & 200 \\
\hline Marzo & $10-11$ & $\begin{array}{l}\text { Resiembra de café (replanting } \\
\text { coffee) }\end{array}$ & 2 & 40 & 80 \\
\hline Junio & $23-28$ & Limpia & 5 & 40 & 200 \\
\hline \multirow[t]{2}{*}{ Agosto } & $15-20$ & Resiembra & 5 & 40 & 200 \\
\hline & $25-30$ & Cajetiado & 5 & 40 & 200 \\
\hline
\end{tabular}

Don Lorenzo's registro (record) demonstrates not only the kind of detail included in the requisite documentation, but also the costs incurred for producers who hire paid laborers. As a member of Alta Gracia, though the labor costs incurred here may be greater than those of the other two communities, this registry is typical of the kinds of tasks and the schedule required for organic certification that accompanies participation in both this fair trade system as well as the certified Fair Trade system. In Grupo Organico and La Esperanza, these tasks are more likely to be addressed by unpaid 
family labor. Alta Gracia residents surveyed reported a median of only 1 family member to assist them in cultivation duties, while in Bella Vista residents reported assistance of 2 family members and La Esperanza residents clamed 3 family members involved in production. Either way, in the form of paid or unpaid labor, organic certification requirements that accompany access to fair trade markets generate considerable additional labor demands in all stages of production.

\section{Preserving natural resources}

The most contentious of all production requirements pertains to abono organico, or organic fertilizer. Interviewees repeatedly stated that the only meaningful difference between Grupo Organico and Grupo Convencional was the application of fertilizer, which in conventional coffee production may include application of chemical inputs. While it is true that Grupo Convencional members and some residents in La Esperanza begrudged organic production for its prohibition of chemical fertilizers, more aggravating was the difficulty of producing and applying organic fertilizer. The requisite organic fertilizer comes in 100-pound sacks and usually has to be carried on one's back to the coffee plot, located anywhere from 15 minutes to over 1 hour walking distance. Chemical fertilizer, on the other hand, covers a greater expanse of land than its organic counterpart. As one resident explained, "Adding pulpa (organic fertilizer), carrying those sacks, and you have to use so much per plant. But

chemical, I buy a bag, it covers 3 cuerdas $\left(131.1 \mathrm{~m}^{2}\right)$ and the production is fast. Working organic is hard because, when is the work going to be over? It's 
hard." (Ezequiel, interview, February 25, 2010). To cover the same area as one quintal of chemical fertilizer, 20 quintales or organic fertilizer would have to be manually hauled to the coffee plot, presenting a significantly greater investment of time and effort, should one labor on their own plot, or money, should one have to pay hired laborers. Considering the average land holdings in coffee cultivation range from 15 cuerdas in Bella Vista, where plots are located on steep slopes, to 28 cuerdas in Alta Gracia, though the land is relatively flat, to 47 cuerdas in La Esperanza, where families receive one plot in each of the steep and relatively flat zones of the community, the difficulty of hauling multiple 100-pound sacks for upwards of 30 minutes along sheer mountainsides should not be underestimated.

In its favor, organic fertilizer is much less expensive and lasts longer, so it requires fewer reapplications than its chemical counterpart. The cost of chemical fertilizer is prohibitive, as much as $300 \mathrm{Q}$ per sack, while organic fertilizer can be purchased for around $30 \mathrm{Q}$ per quintal, less in Bella Vista where an Anacafé subsidy has lowered the price to $20 \mathrm{Q}$ per sack, or even produced by the growers themselves with an additional investment of labor. Furthermore, the effects of chemical fertilizers are relatively fleeting, so reapplication is essential, while organic fertilizer is considered an investment in the long-term health of one's coffee plots.

For example, the Grupo Quimico [Convencional] has many advantages. On one hand, they are advantages, on the other hand they are losses. They say, a coffee plant, there is a Don who before was in the Grupo Organico, planted his coffee, and they didn't grow. But when he left Grupo Organico and went to Grupo Convencional, he bought quimico. And he started putting it on his plants, and they look nice now. They will 
produce coffee this year. They are covered in flowers. But it's a disadvantage because he's ruining his land. Because the land gets used to quimico. And it also gets used to not having quimico. For example, my father, see how he has planted his coffee. And what coffee! How it has grown! Only in this one piece he got 25 quintales. Only 2 cuerdas. Aha. And he cut 25 quintales, but he did it with pure broza [decomposed organic material] and lombricompost. Where you were the other day, he just planted it a year ago, and he has added lombricompost two times and they're already producing coffee. And now they are white with flowers. So the Grupo Convencional has an advantage because they are already growing and producing coffee, but they are losing economically because you have to invest a lot. With pure organic it's time, to prune and add the broza. - Catalina (interview, February 20, 2010)

Chemical fertilizer should be applied three to four times throughout the course of the year, compared to organic fertilizer which only needs to be applied once annually. In practice, however, chemical users in Grupo Convencional rarely ever apply as much fertilizer as is recommended. Fertilizer application presents another instance where coffee growers have to weigh the relative gains and losses to be had with participation in either the Fair Trade and organic or the conventional system. And again, the impetus for resuming conventional production was not so much a desire to engage in chemical production as freedom from restrictions on cultivation practices. In fact, only $42 \%$ of Grupo Convencional respondents actually applied chemical fertilizer to their coffee plants last year.

Organic retains more strength to the end of the year. In contrast, chemical lasts maybe 2, 3 months. And then it requires that you add more fertilizer. It grows and then you add more, and so on. That's how it is in conventional. But we don't add much. Of chemical, not much. It takes money, too. It costs 300 a quintal... every 4 months maybe or 3 months. It's applied in the month of May, September, yes, May, September, and December. Those months. Every 3, 4 months or so... very little. When we have money, we buy. When we don't, we don't. For example, I bought an arroba, 25 pounds. Like that, very little. And I 
applied it to my little seedlings. And when you are able, then you apply it to the grown plants. But the money is the thing we don't have. Yes. It's difficult. That's how it is in conventional. -Efraín (interview, February 4, 2010)

In the community of Bella Vista, which had around twenty years of experience in conventional cultivation prior to the last ten years as Fair Trade and organic certified, many members of Grupo Convencional additionally questioned the efficacy of organic production techniques. "Nos fregaron las matas." [They screwed up our plants.] Several producers blamed a succession of poor coffee harvests on organic methods, particularly the media luna (half moon) technique of cutting into a plant's roots to apply fertilizer. Moreover, one producer described the system as natural, that by not applying chemical they were doing nothing to help the plants, instead just leaving them to grow on their own.

When asked about Grupo Convencional's complaints with organic techniques, one promotor (promoter, elected by cooperative members to advise on best practices in the coffee fields) first chuckled at what appeared to be a familiar story, and then exasperatedly explained that not all residents seemed to share the vision of ecological production, or the practice of treating all the resources available as useful productive material. Specifically, natural and non-use of chemicals did not imply total inaction on the part of the producer. Rather, producers were expected to actively apply organic fertilizer. However, interviews with members of both groups revealed that most producers habitually apply broza [literally meaning brush and dead leaves, which are piled and allowed to decay into rich soil, but also referring to a more 
complex mix including sacate (weeds), levadura (yeast), ceniza (ash), melaza (molasses) or panela (brown sugar cake), gallinaza (chicken excrement) or estiercol (cow or pig excrement)] as a habit, without deeming it "organic fertilizer". Therefore, to prescribe an action already being performed may feel as effective as "doing nothing". Furthermore, the media luna and other practices were prescribed as part of a vital renovation program, bringing new vitality to old plants and uprooting nonproductive plants to be replaced with new growth. Trenches are dug to be filled with fertilizer so that the roots grow stronger by reaching for the fertilizer, but if no fertilizer is added then the roots will die waiting. Though initially devastating to production volumes, older plants eventually rebound while new plants produce at maximum volume within two to three years. Many members of Grupo Convencional were unconvinced and feel they now have to recover from their experiment with organic techniques.

According to the largest producer in this community, the president of Grupo Organico, the secret to success is constant renovation of coffee plants. Among the Bella Vista residents surveyed, their oldest coffee trees averaged only 20 years, meaning all trees had been replaced in their time as landowners. In both Alta Gracia and La Esperanza, however, the oldest coffee trees averaged 40 years, the point at which coffee trees become mostly unproductive. Whether or not Bella Vista residents appreciate the renovations mandated by their organic certification, the result is that they had the greatest majority of relatively young and productive plants, which bodes well for their productive future as coffee growers. 
Despite the difficulties of organic production techniques, members in Grupo Organico persist in following certification requirements in large part because they feel the environmental benefits outweigh the drawbacks.

Perhaps, then, yes there are advantages and disadvantages, because the advantage is that to work on organic production you can find what are the insumos (inputs) or the abonos (fertilizers) from what is already in the same plot. Everything from the sap from the trees you are trimming, the ceniza (ash) from the house, everything can be used to make your own abono. But it is a big job. It takes a lot of work. That is the disadvantage, then, for taking so much work like this in organic. Because, for example, to fertilize, to fertilize the coffee plants I bought 20 quintales of abono this year. The stuff from the worms [vermicompost]. And each quintal lasted me 20 plants, no more... The thing is that there are different ways of thinking, and those who follow what is organic, I think that is because they have noticed the contamination in recent years. So they are here because they do not want to continue with this contamination. So we have to put a little, empower ourselves to go and help the naturaleza (wildlife) a little. We have already seen so much, and we continue killing with so many chemical products, so I think that is the reason why some of us are still working in organic production. -Eugenio (interview, January 23, 2010)

One of the dreams would also be to care for things in el medioambiente (environment). Yes, all of us in Fair Trade, we do not accept that anyone uses herbicides in the coffee plots. You have to make barriers, you have to care for the land, care for the animals, and everything. It is understood, then, that one is working with the environment... On the other hand, the conventional growers [not Grupo Convencional] just buy Thiodan (an insecticide) and fumigate with water and it has a terrible odor and Fair Trade does not like it. They don't like it because it makes the children sick, and we are doing it. For example, to speak of la hierba (greens) is a hierba that we eat. They are healthy greens that don't contain any chemicals. These are the advantages of Fair Trade. You feel good and you see before your very eyes that your life is calidad (worthwhile) because you are working with the environment. Cristóbal (interview, February 2, 2010)

While only one producer in either of the other two cooperatives cited

during interviews the preservation of natural resources as an advantage of Fair Trade and organic certification, residents in Bella Vista focused on the 
environmental impacts of each group's form of production. Even members of Grupo Convencional harped on the damaging effects of chemical use. Grupo Convencional members were concerned that we understand the difference between chemical fertilizer, which they apply only in small amounts, and other chemical inputs such as pesticides and herbicides, which are viewed as significantly more harmful and are strictly prohibited for use by either cooperative in Bella Vista. The following passage, in which a member of Grupo Convencional explains the tradeoffs of chemical versus organic production, exemplifies the aversion to chemical use and reverence for "organic" production, here meaning cultivation in absence of chemical inputs.

We add urea [a commonly used type of chemical fertilizer] to the young plants like this and they grow and they produce well. They produce good coffee. That is with quimico (chemical fertilizer). The organic one is pulpa. That is organic fertilizer. It doesn't produce right away, but it lasts. It lasts. On the other hand, quimico is faster. Already within the month you can see the young plant looks good. It grows right away. Now, organic is slower. But it is safer. But you are not going to spray Gramoxone (an herbicide), they say. That's what they say. Do not apply Gramoxone because it washes away the land. It washes away the land when it rains. So with a machete, with machete we clear the coffee plots. It's better this way, we say... In conventional what they use is veneno (poison). To fumigate. But it's dangerous for your health. You have to use a mask. And you carry it in a mochila (backpack) and fumigate the plants like this, on the leaves. But its veneno. It can kill a person. And it works against [coffee] sicknesses. Against la plaga (coffee diseases). So we don't buy it out of fear. [laughs] Fear for our health... We don't spray it too much, either... It grows with the broza. We just help it a little. Yes. So that we don't make too much contamination. Otherwise, with more quimico or venenos comes more contamination of the environment. And the air carries it and you breathe it. And it's not clean air. It's air contaminated with veneno. On the other hand, here the environment is clean, there is more organic [production], not quimico, not conventional. So you breathe clean air. Notice, you guys, when you go down to the coast, you'll notice unpleasant odors. It makes you sick. It's the same for us. We eat a lot of contaminated things, they tell us, and with quimico there comes sickness, too. 
Sicknesses to our health. For example, here in Guatemala there is a lot of sickness. So, they say it's because of the quimico... That's the other effect. With quimico it [coffee] grows quickly but then you die quickly, too. You don't breathe well. It brings awful fumes. On the other hand, here - no. So, for that reason we don't use much either... It's not very good to use veneno for the plants. Not much. Therefore, we, too, are doing better to use cal (lime) and nothing more. Cal. Cal we add to the plants. And that's how to kill the sickness a little. But there's not really much [sickness], perhaps because of the cold. Not much. Because of the cold it doesn't affect us. I only know because I have heard of this, as we say here, "teóricamente" (theoretically). -Efraín (interview, February 4, 2010)

The list of hazards resulting from chemical use is long, including pollution of air and water, harming the health of both adults and children, causing landslides during rainy season, and killing the edible plants along with the weeds. Grupo Convencional members expressed just as much, if not more, concern with the negative effects of chemicals as did Grupo Organico members, emphasizing their awareness of the dangers of chemical use and their efforts to minimize the amounts they use. In this way, the decision of Grupo Convencional members to abandon Fair Trade and organic certification can be seen as motivated not so much by a desire to employ chemicals as a reaction to so much intervention in their cultivation practices.

\section{COMPETITIVE MARKET STRATEGY OR ‘ESCLAVITUD’?}

As a strategy for increasing a cooperative's earning potential in the coffee trade, the pros and cons of certification are difficult to evaluate. Individuals as well as cooperative leaders are constantly calculating what they stand to gain or lose in each possible configuration of personal versus paid labor invested, the cost of fertilizer versus the cost of its application, short-term 
versus long-term increases in production, waiting for payment versus availability of credit, and, not least of all, securing a reasonable price versus gambling for a higher price. In the end, balancing the demands of certification with the benefits of Fair Trade is key to producers' satisfaction with Fair Trade.

Viewing the current market system in which each cooperative participates can be taken as an indicator of the final ledger of advantages and disadvantages, then Bella Vista's Grupo Organico can be said to conclude that Fair Trade certification vale la pena (is worthwhile) in the end. For all the challenges it poses, the outcome is worth the extra effort. For the Alta Gracia cooperative, certification fees and prospects of a more closely-knit trade relationship tipped the balances in favor of abandoning Fair Trade for a different position in the spectrum of fair trade. In La Esperanza, certification required entirely too many changes to production with little payoff. Bella Vista's Grupo Convencional shared this sentiment, likening certification requirements to oppressive working conditions of their past days as finca workers. The latter two groups, it seems, did not share the same value that the former two groups placed on the benefits of Fair Trade. In their calculations, either the benefits to be gained were not enticing enough or the costs of participation in Fair Trade were not bearable, or perhaps both.

The present chapter has examined the scenario in which the costs belying the benefits are too great for fair trade to be worthwhile. This costbenefit imbalance is identified particularly by members of Grupo Convencional, who felt that the market and cultivation restrictions accompanying the price 
minimum rendered Fair Trade insufferable. Presented as a strategy for gaining a market advantage, demanding much on the producer end, then resulting in little price increase over their former conventional system, Fair Trade appeared as a great swindle, ultimately granting producers less, rather than more, agency in the international market. As one Grupo Convencional member explained, Fair Trade could not "garantizar su trabajo", could not guarantee that the effort would pay off in the end.

Grupo Convencional as well as La Esperanza residents focused on the obscurity of deductions for services rendered by Toro Verde. Though the former expressed little criticism for certification requirements, they never fully met the requirements, either. Furthermore, La Esperanza residents also shared Grupo Convencional's frustration with being locked into a price rather than actively engaging in price speculation. Despite their signed contract, they continued to monitor movements in the international market. And like both groups in Bella Vista, they constantly evaluated the diminishing price differential over conventional market sales. In this way, both Grupo Convencional and La Esperanza gauged the worth of Fair Trade in terms the price advantage it offered, ultimately determining that the price did not compensate for the trouble.

Weighing the economic impact of a given market system is tricky business, especially where precise costs of labor and time invested can vary by household structure and years of experience or offset by missed opportunities. Moreover, many of the counter-effects are intangible, such as 
cleaner air and working "por su voluntad" (of your freewill). But when discussing the advantages and disadvantages of fair trade, both communities tended to balance out their criticism of fair trade with appreciation for the noneconomic benefits it offered. For example, Grupo Organico members frequently mentioned environmental protection as one of their main concerns. When asked why they remained in organic certification, despite the increasingly trivial price advantage, despite the burdensome labor requirements, they explained that protecting their natural resources was of greater importance.

Social impacts, on the other hand, are almost always plainly positive, and producers from Alta Gracia as well as both Bella Vista groups consistently cited social development as a valuable benefit of fair trade. In addition to environmental protection, producers in a fair trade system often receive networking support, donations, aid in times of natural disasters, trainings, and a sympathetic trade partner who will remain loyal despite difficulties in meeting the terms of trade. For come cooperatives, then, the appeal of fair trade has come to lie just as much in the indirect benefits as the direct economic impact. La Esperanza, however, differs from the other communities is in the absence of either environmental protection or social benefits from their discussion of Fair Trade. Either due to the brevity of their relationship with Toro Verde, or because their social development needs are already being met elsewhere, residents of La Esperanza did not see the indirect benefits as sufficient incentive to continue participating in Fair Trade. 
Though the fair trade system may not live up to their economic expectations, producers in Grupo Organico and Alta Gracia still believe the fair trade option is worth its trouble. Viewed this way, fair trade is seen as employing a "bait and switch" tactic, where the system is not experienced as advertised, in fact generates significant costs in production and often produces disappointing financial results, but sustains its members by offering unanticipated benefits in non-economic realms. The next chapter focuses on the more unambiguously advantageous features of fair trade, examining the auxiliary benefits to participation in a fair trade network.

For producers who have grown weary with disappointment in traditional sources of development support, fair trade introduces new avenues for networking. The following chapter first provides the development history of these three communities, examining typical sources of support, the types of projects attempted in each community, "successful" and "failed" outcomes, and the differences in approach that may explain these results. Focusing on the development projects that coffee growers value as enhancing their wellbeing, the chapter will then consider fair trade partners as agents of development, examining the types of support these partners offer and the way in which this support is delivered. This discussion will illuminate the differential valuation the three cooperatives place on the various benefits and drawbacks of fair trade, finally explaining the considerations made in each cooperative when determining which market system is better suited to their needs. 


\section{Chapter VI: Fairness Beyond Trade}

Coffee is, I mean, my opinion is, and just based on what l've seen, l've only been doing this for a little short of ten years, but, l've never seen a farmer, contrary to what Transfair or whoever will tell you, fair trade will not pull a coffee farmer out of poverty. It won't. It can't. There's absolutely no way, structurally. It's impossible. And so, the best that we can do is to help pay farmers what their work is worth and what their coffee is worth, a fair price. And then help them diversify to where coffee is not what they're solely dependent on. And being solely dependent on an export crop is not, it's just not a perfect, I mean, that's my opinion, I'm not a coffee farmer, but talking to coffee farmers, it seems to be some agreement that it's just, I don't think it's out of line to call it a dead-end street, if you don't have any other alternatives. I mean, it's just this perpetual cycle. The most successful coops that we work with we see being able to diversify into other things, other relationships, to where coffee is only sort of one facet of their subsistence strategy. And so that's what our deeper goal is, to work with coops, to realize what their community development goals are, and, any way that we can, help them get there. And sometimes we'll do fundraisers. Sometimes we straight up donate money. But more often, these days, we work with other non profits and organizations here in the US and outside the US to try to figure out how to get these guys to where they want to be. -Kenneth (interview, September 11, 2009)

As this chapter will demonstrate, the most uncontested benefit fair trade can offer a cooperative is extraneous to terms of trade. In a realm outside the negotiations of prices and premiums and quantities, fair trade offers significant benefits to the social development of cooperatives as well as the communities in which they are situated. Sharing a belief that, "No one ever broke the cycle of poverty by earning a few cents more or less." (Dean Cycon, personal communication September 15, 2009), Fair Trade Federation member roasters Roundtable Roasters and Dean's Beans emphasize the importance of supporting producer communities beyond the bounds of a coffee purchaser's agreement. As current and former purchasers of Alta Gracia's coffee, both organizations have committed considerable resources into the social 
development of the community. Producers in the Fair Trade network also receive considerable development support to complement the economic impact of coffee sales, though in the case of Grupo Organico it is the purchasing cooperative fills this role rather than the importer or roaster.

By pursuing an approach Cycon terms "people-centered development," fair trade offers a unique form of support that coffee growers recognize as providing successful improvements in both daily life and the future of the community. Producers in all three communities can cite endless examples of development efforts that have fallen short of expectations, often due to the brevity of support or lack of consideration for region- and cooperative-specific conditions. In contrast, by investing in long-term relationships and project ideas generated by cooperative members, fair trade can provide development support with appreciable results.

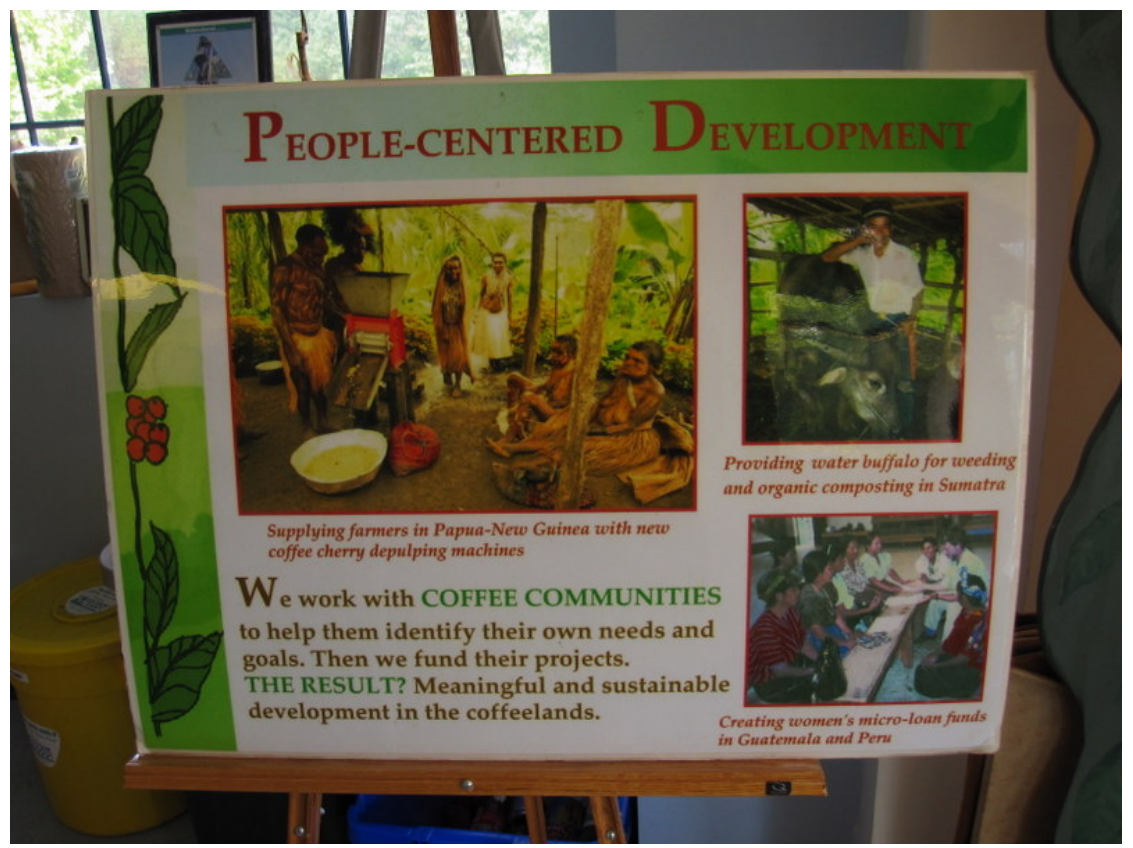

Figure 6.1 People-centered development: philosophy promoted in the Dean's Beans roasting facility 
To provide a context for comparing the support offered by fair trade members with other available forms of support, this chapter will first outline the development history of these three communities, examining various sources of support as well as project outcomes. Next, an evaluation of the reasons why so many projects fall short of expectations suggests changes in approach that might lead to greater success. Then, fair trade is presented as a potential foil to some of these key causes for failed projects, especially because of the unique relationship it creates between producers and purchasers. A review of benefits to fair trade cited by producers reveals that the greatest value producers find in the fair trade network lies not so much economic impact as in development support, specifically, in access to resources for reinvestment in production, educational opportunities for children and adults, and networking assistance to secure other needed resources. Finally, the chapter concludes by cautioning against fair trade as a panacea, illustrating how the very virtues that allow fair trade players to initiate effective development may alternately be viewed as detrimental to aid recipients and their communities.

\section{DEVELOPMENT HISTORIES}

The history of development in that community is long. Long. But the history of successful development there is very, very short. Very short. The roaster is the only one that's kicking. And that's cause of Benigno. -Jamie (interview, September 15, 2009)

And the roaster is no longer kicking, either.

In fact, the history of development in each of these communities is extensive. A discussion with community members about their development 
history reveals a long list of attempted projects of varying fates, sources of funding, and inspiration. Some community members are still welcoming of any new opportunity that may present itself, whatever it may be, and remain enthusiastically open to the suggestion of activities in which they have not yet dabbled. Others have become more conservative in directing development efforts. There is no disagreement, however, that development support is desperately needed in each of these communities.

Rampant political corruption, decades of unfilled campaign promises, and frequent turnover of elected leaders have left these communities with little expectation for assistance from the national government. At the regional level, allegiances in local elections often determine which communities will obtain funding for their proposed projects:

It's difficult. It's difficult because here in Guatemala politics are very hard and very, how can I say, for the worst... I heard that those men who came, word is they said they came supposedly because of a project that Bella Vista was involved in with the government ... but I heard that it might be closed to us, or they say because of who you voted for, or because you voted incorrectly, you didn't vote for this person so there won't be any project. So it's for that reason that it's difficult to ever get anything because the politicians and government workers are only looking out for personal interests, nothing more. They don't look out for the interests of different communities. It's very difficult." -Eugenio (interview, January 23, 2010)

An infamous example of such unfulfilled promises lies in the unending construction of a highway intended to connect the community of Bella Vista to the geographically nearest city of Quetzaltenango. Though the community is located less than seven miles from the nation's second largest city, no drivable route exists to connect the two points. Instead, residents travel nearly two 
hours by bus to the city of Retalhuleu to shop, work, attend school, or visit a doctor. Construction of the highway was hoped to open to community residents new opportunities for employment and education, as well as relieve some of the economic burden imposed by emergency travel to the nearest hospital. While construction of the highway began in the late 1990s under the presidency of Alberto Arzu, it has been abandoned and resumed in sync with the cycles of election years. Over ten years later, project completion continues to appear as a campaign promise in municipal elections. In its present state, the road is only useful to residents insomuch as an example of politicians' apathy and attempt to manipulate the gullible.

With the exception of service provisions that accompany the Fondo de Tierras agreement in two of the three communities, government assistance has been limited to teachers - in school buildings that the communities construct and maintain - and the occasional small donation of items such as fertilizer, seeds, beans and rice, or materials for house construction. These donations, however, are granted on behalf of political campaign agendas, providing much needed but temporary and insufficient relief to ongoing problems of inadequate housing and malnutrition.

In the absence of government support, these communities have developed what they see as self-sufficiency in addressing their development needs. As one resident explained,

Well the people, to speak a little of Bella Vista then, it's that almost all we see, what you see is work done by the community, and in other areas we have received help but very little. And of the government workers there have been in this time, then, they haven't helped with 
anything. Nothing. Only teachers." -Cristóbal (interview, February 2, 2010)

Much of the "work done by the community" consists of soliciting funding from external sources, including both local and international NGOs, international governments, the Catholic Church, and coffee purchasers. The channels of support that have opened to these communities are varied, due in part to their divergent backgrounds. With the Catholic church as its founder and benefactor, Bella Vista has received ongoing financial support from the Pastoral de la Tierra, a church-based organization of agronomists and development workers who helped establish the community's tostaduría project and initiated the conversion to organic and Fair Trade certification. The other two communities, on the other hand, have found the development support they seek primarily through foreign government agencies and NGOs. These two communities have had assistance from such high-profile organizations as the Spanish Red Cross, the Japanese and Swedish Embassies, the United Nations, and USAID. In addition, these two communities have had volunteer assistance since the founding of their cooperatives, from the construction of their homes to initial lessons in organic coffee cultivation.

The level of engagement of these development agents can be seen to impact residents' satisfaction with the programs in their communities. Engagement varies both in terms of length of involvement in the project as well as collaboration in project design. Additionally, certain types of projects are more likely to be described by residents as successful, in that they contribute to the wellbeing of the community. Specifically, new income- 
generating activities were less often viewed as successful endeavors, while investments in infrastructure or already-existing activities were described as beneficial to the community and sorely needed in greater supply.

This chapter will outline the different sources of development support in these communities, the various projects endeavored, and the outcome of the programs, to identify the types of projects most appreciated by residents and the role the fair trade movement plays in supporting development.

\section{Foreign government agencies}

Assistance from foreign governments has primarily contributed to infrastructural development in the communities. After the signing of the Peace Accords in 1996, European and US government agencies concentrated some of their development efforts on rebuilding the Guatemalan economy and repairing the devastation of rural villages. Through this effort, Alta Gracia received funds and materials from the Spanish embassy, along with the International Red Cross, for the construction of homes in their newly settled community. In addition, the European Union contributed the funds for training in coffee cultivation, much needed for the majority of residents who arrived in town with no prior experience in either coffee picking or growing. In La Esperanza, their Fondo de Tierras loan was accompanied by funding from the United Nations to construct a hydroelectricity project and the power lines to provide limited electricity service throughout the community.

Foreign assistance has continued beyond the initial settlement programs, as governments with interest in the economic development of the 
rural Guatemalan countryside continue investing in income-generating activities of the communities. Bella Vista and Alta Gracia both solicited foreign governments for the funds to establish their tostaduría (coffee roasting) projects.

We sent the petition to Austria and Austria supported all the machinery installation with the 150 thousand [ $\$ 19,230$ US] we received from them. And from there we started buying the raw material of coffee, packaging, grinder, roaster, retriya (used to remove the hull from the coffee bean), selladora [sic] (used to seal packages), the generator that we have here and it built the multi-purpose room that's here. We did it with that money... The packaging was donated by the institution called, I don't know if it still exists, AID of the United States. Yes, because, this is that one, they donated to us the packaging. -Sonia (interview, February 8, 2010)

And when we did the project and presented it to the Japanese embassy, they supported the project, sent their support. They donated $113,000 \mathrm{Q}[\sim \$ 14,487$ US]. With this money we bought the machinery, the roaster, also a retriya, but we weren't able to install it for lack of some motors. The retriya is still here. A grinder, the selladora for the bags. And also it covered us for the construction of the bodega. Rodolfo (interview, March 15, 2010) 


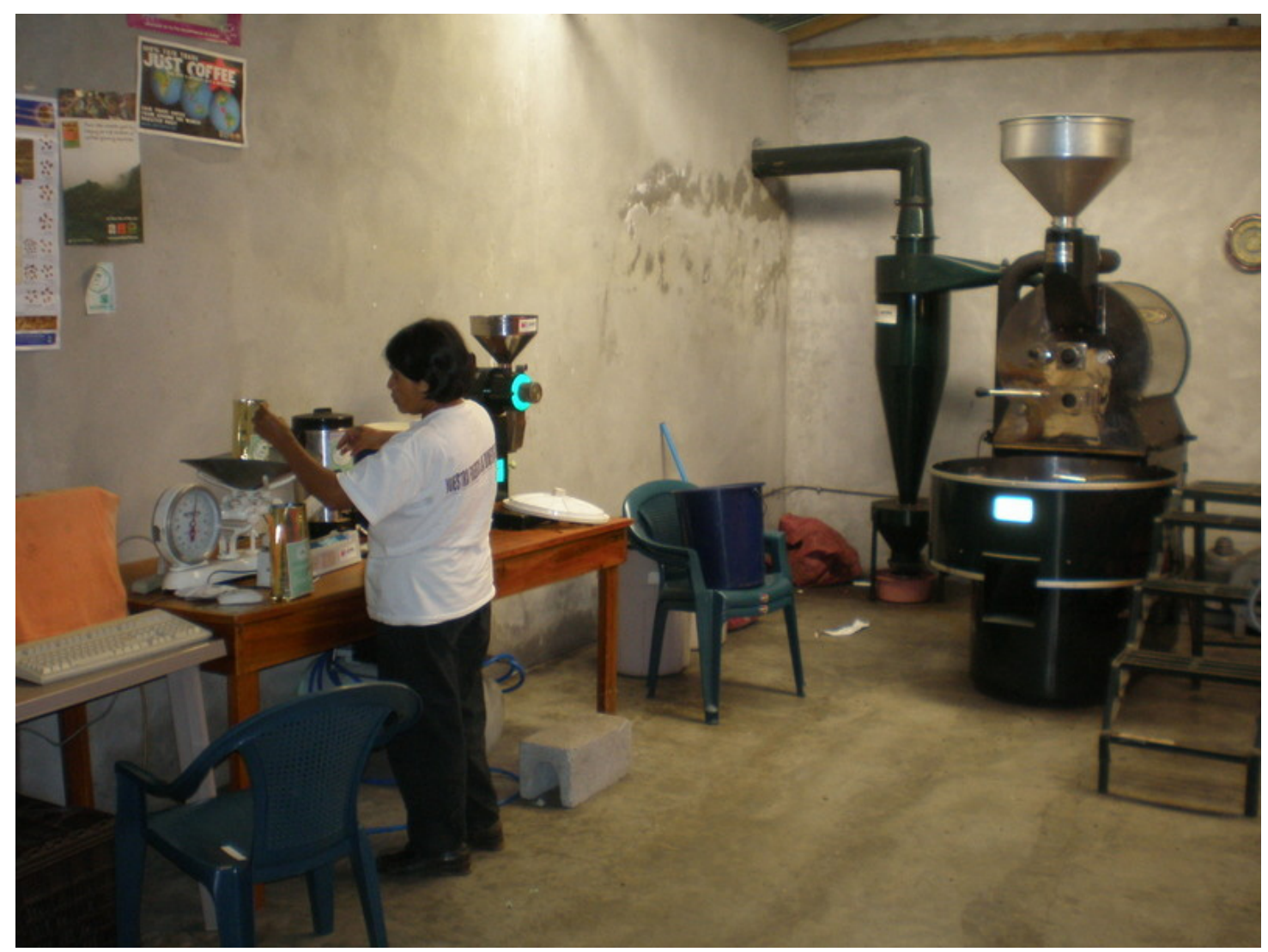

Figure 6.2 Tostaduría: and Alta Gracia resident weighing and packaging roasted coffee

These tostaduría projects were both funded in response to requests from community leaders, written with assistance from outside NGOs. In contrast, assistance has also been granted without solicitation, but to fund projects suggested by external agencies. La Esperanza, for example, received a donation in 2009 from the Swedish Embassy to finance organic and Fair Trade certification of their macadamia and coffee production.

So I, along with the visits we have had from other organizations and everything, I noticed that the certification supports, gives value to products. So right now we are already certified organic. We will sell the coffee just like macadamia [organic] this year. For the coffee price we have received approximately 48,000 quetzales [ \$6154 US]. For the macadamia we are just now going through the process so that they can deposit for us something like 65,000 quetzales [ \$8333 US]. And that is only for the organic certification. Right now we are planning this year to get certified for what is called fair trade and there we will get a little 
more incentive. That's the idea. - Timoteo (interview, December 2, 2009)

In fact, many of the development projects attempted in these communities have been initiated by external forces. Groups and individuals visiting the communities identify what they see as opportunities for development, mostly economic, and work with residents to lay the foundation for projects of their design. Unfortunately, the vast majority of these projects perish quickly once external support is withdrawn.

\section{Ecotourism and "development tours"}

Foreign visitors to these communities have proven significant channels for funneling aid into the two younger communities. In Bella Vista the ecotourism project is relatively new, initiated in 2009 , and my research partner and I were the first guests to stay in the newly rehabbed former plantation owner's house-turned-albergue, or shelter. Visitors may find the communities through their websites, in which they share their stories of struggle and settlement, or through Spanish schools in the nearby city of Quetzaltenango, where flyers advertise an authentic experience of rural Guatemalan life and the opportunity to contribute to community development through volunteer work. Additionally, Alta Gracia's coffee purchasers in the US promote weeklong "delegations" to experience a week in the life of a coffee grower and learn about the involved process from coffee plant to cup. The compelling stories of the younger communities, as squatters reclaiming their homes or excombatants rebuilding a life post-war, has effectively drawn a constant stream 
of visitors from the US, Canada, Europe, Israel, and South America, eager to make a contribution of manual labor, English lessons, money, supplies, direct product sales, and the occasional development project startup. Bella Vista instead promotes their remoteness and wilderness, complete with waterfalls, rivers, and two rare Resplendent Quetzal sightings, so remarkable as to land them a feature story on a local news channel.

The length of stay of these "development tourists" can range from a weekend to several weeks to several months, though a stay of two weeks or more is considered lengthy by community residents.

... Because people come down and they love it and they get some money to help out the community, but they don't then stick around. Like, that's a huge thing with Alta Gracia is that there's so much visibility and visitation that happens there that all these well-meaning folks come down for a little while and then sort of just start up things in the communities, like, alright, go along with your plan and they leave, it's done. - Jamie (interview, September 15, 2009)

Greater presence of outside assistance has resulted in both a lengthier list of attempted development projects, as well as a more diverse network of funding sources. Rebuilding a new community and uncertain of the recipe for success, these communities typically respond to proposals with a willingness to try anything.

Yes, we are people who are interested in getting ahead. Getting further ahead, for our children more than anything. If a project comes along and projects have come - we look to see if it's lucrative for us, we give it a try. We are not going to say, 'No. No we're not going to try.' ... You cannot say it didn't work, it screwed us up because of this and this, no no no... not if we don't know what will happen that could help us get ahead. - Isidro (interview, December 3, 2009)

Well, anyway, I like to be very liberal and to take any means to find support. Therefore, within this solicitude, they bring us a pair of pigs 
and a pair of cows, somehow to feed them and if possible, sell them. It was to my surprise when they responded by telling me about a pig project and a cow project, not a pair [of pigs or cows]. So I had to accept them because I couldn't say 'no'. But over time and while the project was developing we saw that it wasn't lucrative for us. - Timoteo (interview, December 2, 2009)

In fact, pig-, cow-, and chicken-raising seem to be features of community start-up development support. These projects also appear as disappointing failures in the development history of Bella Vista, where, as in the other communities, no suitable land was available for pasture and cost of animal feed quickly outstripped the potential gains from sales. In another effort to establish food security, all three communities share experiences with organic vegetable production projects, supported both by local NGOs and volunteer tourists.

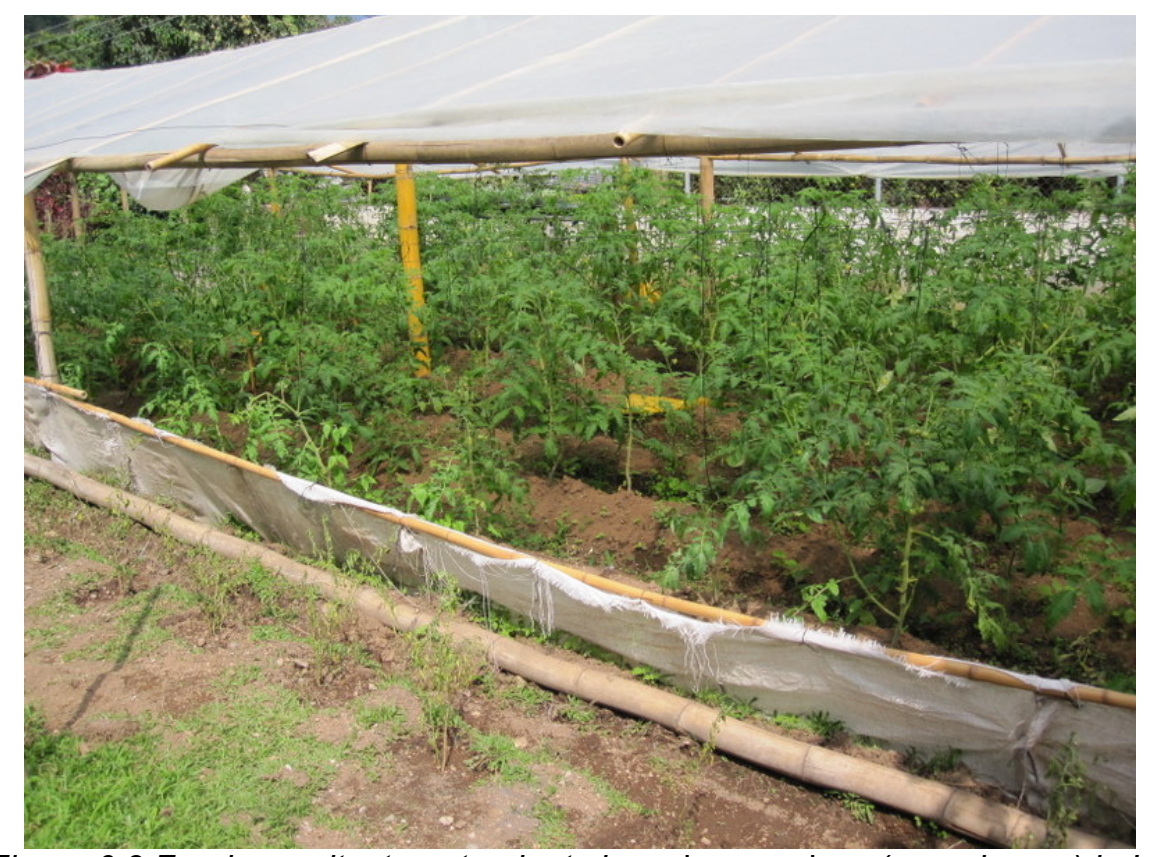

Figure 6.3 Food security: tomato plants in an invernadero (greenhouse) in La Esperanza's short-lived hortaliza (garden vegetable) project 
While food security projects are common to all the communities, their unique project attempts reflect the trail of volunteers and tourists visiting the two most trafficked communities. For example, La Esperanza, a more popular destination among European and South American backpackers, has dallied in biodiesel and biomethane production. Both projects were initiated by volunteers in an effort to turn readily available resources into marketable products. Similarly, Alta Gracia, more frequented by US and Canadian college and university groups, received a donated oven, bread tins, and other materials for a banana bread baking project, intended first as a project for the community youth, then for women, to earn income from the bananas grown alongside coffee. Visiting students also painted and organized a community library that houses donated books. Several universities organize annual trips to for students interested in Guatemalan history or development work, usually leaving donations in their wake. Most recently, a returning group of university students donated desktop computers and startup funds to establish a for-profit computer lab in Alta Gracia, with a sliding scale that charges a higher rate to foreign visitors.

Unfortunately, the majority of projects introduced from outside parties and envisioned as ongoing or self-sustaining meet their demise shortly after the departure of their promoters. Development workers and community leaders offer various explanations for the frequency of failed projects, to be discussed below. It is certainly not the case that all such projects are doomed, nor is the reverse - that the majority of projects conceived within the 
community are successful - true. In such cases, local NGOs are often called upon for supplemental support and funding to limp along already failing projects.

\section{Local NGOs and governmental organizations}

Several projects requested by community residents, including a bamboo furniture manufacturing project in La Esperanza and the tostaduría project in Alta Gracia - failed to achieve self-sustaining status and were eventually abandoned. Before they were final demise, however, petitions may be sent to local organizations for bailout support. These organizations generally have a specific development focus - such as fair trade coffee or organic vegetable cultivation - and seek national and international funding both for projects on behalf of farmer cooperatives. In the case of Alta Gracia's tostaduría project, though a local NGO loaned tens of thousands of quetzales to purchase the materials needed to continue sales of processed coffee throughout the 2009-2010 harvest, the project could not be saved. Instead, bankruptcy and indefinite suspension of the program has compromised the financial stability of the loaning organization. In La Esperanza, the community continues to request funding to purchase furniture-making materials since the local bamboo has not replenished itself as rapidly as hoped. In another instance, the compost and organic vegetable projects imploded due to internal conflicts and community politics, so that the supporting NGOs will have to retrain new staff if the initial investment of supplies and materials are not to be discounted as a total loss. 
Last resort funding source is not the only role played by local NGOs. Some of the more appreciated and satisfying development programs in these communities have been supported by such organizations as Anacafé, the Guatemalan National Coffee Association, and FUNDAP. These organizations have focused their support primarily on workshops to develop new skills or advance training in existing projects. Residents in Bella Vista recently participated in FUNDAP courses in tailoring, baking, hair trimming and styling, and wood cutting, skills that several residents have turned into for-profit side work done from home. To promote coffee production, both in terms of volume and quality, Anacafé offers advanced training for workers in the coffee beneficio, as well as workshops on coffee disease prevention. Furthermore, Anacafé donated the materials necessary to construct ecological water processing and vermiculture facilities, the latter of which has been so successful in Bella Vista that the next request for support will propose an expansion to accommodate steadily increasing demand for organic fertilizer.

\section{UNDERSTANDING THE LESS-SUCCESSFUL VENTURES}

Bella Vista's vermiculture project and La Esperanza's bottled water project - a community-initiated and externally-funded endeavor - are among the greater successes in the development histories of these communities. Of the more than 45 development projects described by members in these three communities, many of which were one-time investments in materials, less than half continue to benefit the communities today. While it is difficult to pinpoint the precise characteristics that comprise a "successful" development project, 
one that is recognized by the community members as beneficial to their wellbeing, a few similarities can be found among the more appreciated efforts at community development.

Few income-earning activities are described by residents as successful investments in development. While cattle, pig, and chicken raising, biodiesel and biomethane production, banana bread baking - and even banana cultivation - offered little benefit, all three communities value continued investment in coffee cultivation. La Esperanza has more diverse incomeearning options, with lucrative macadamia and bottled water projects, and residents overwhelmingly prioritize investment in strengthening these projects over initiation of new endeavors. All communities enthusiastically invest in their ecotourism projects, as well, as this is viewed not only as a source of income for the community, to varying degrees, but also as a means of international networking to generate support for future development projects.

In fact, the majority of development projects described as beneficial to the wellbeing of community residents have been community-generated ideas, often investing greater resources to improve upon existing projects. Where hydroelectricity, the computer lab, biodiesel, and livestock raising have left residents feeling disappointed and incompetent, the purchase of new live barriers to prevent runoff in the coffee fields or expansion of the potable water system constitute appreciable achievements and milestones marking how far the communities have come from where they began. 
Residents offer myriad reasons why projects dissolve or fail to bring about the benefits they had anticipated. One of the most common explanations given is that, generally speaking, the project was a bad match for the needs and the capabilities of the community. Regarding the hydroelectricity project, Timoteo (interview, December 2, 2009) explains, “Unfortunately we had problems because it wasn't established well, or for the lack of experience they had in managing projects, they [Fondo de Tierras with the United Nations] chose a company that didn't meet or didn't have the capacity for this project." When the machinery broke, no one in the community had the capacity to repair the equipment, so the project was abandoned until, ultimately, thieves in the night stole a crucial component of the motor, rendering the project unlikely for reinstitution in the near future. To meet the now-established electricity needs of the community, both for limited use in individuals' homes and in the bottled water, coffee drying, and macadamia shelling projects, a gas-fueled generator is now in use, creating new costs of production.

Similarly, whether introduced by local NGOs or volunteers, none of the vegetable projects have been successful, due to a combination of inhospitable climate, lack of knowledge of vegetable cultivation, lack of community interest, and disagreements over project administration. Though concerned parties consistently identify improved nutrition as a primary need in these communities, the proposals for food security have never proven a good match for the skills and resources available to these communities. Ultimately, 
residents found these projects a waste of both time and money invested. In describing the unique environmental conditions of his community that precluded a successful dairy projects, one Bella Vista resident explained, “There was a communal areal for pasture for cows, but unfortunately it didn't work because of the ash. They ate it and had rocks in their stomachs and died. That and they fell off the steep hillsides." - Ovidio (interview, February 21, 2010) The stories of La Esperanza residents reflect both shared and unique characteristics that doomed their dairy projects to failure in spite of all efforts to succeed:

Yes, we have tried, like with the pigs and the dairy cows, but for us they have only generated costs, and at the same time they made an evaluation that for us it's not lucrative. So in the same evaluation it showed that, well, it was determined that it was not helpful for us to have them because they weren't producing... we finally arrived at a final decision to say, fine, the project is over because it will not be profitable with the cows because the land here is geographically not appropriate for them. Here, the climate, there is no pasture because all of our land is already planted in macadamia and coffee, so there's nowhere for them. And to tear up so many macadamia trees and coffee and plant pasture, in the end it's not profitable for us. -Luciana (interview, December 8, 2009)

I worked in a project of dairy cows. A dairy. I had the opportunity to feed the animals. It was a very interesting project in the beginning. I think many of the people remember it and are thankful to the German community that gave us the project. But unfortunately... here we are not among the pasture required to feed the animals... We had to try to find some way of growing pasture along the sides of all the roads. You can see there is pasture 'at foot', as it is called. The animals came. All cows of this size. There was the pasture, but for the necessity of feeding them we had to cut it even though it wasn't full grown. And that's how it ended. We had to find another finca where they would sell to us, because the animals couldn't go a day without eating. We had to find a way. Later they cut food for the cows in other places, and had to bring it here by car. But we did not have the cars that we have today. No, we had one, no more... The animals went without eating... we saw that it was too much, we were going under for what would be milk 
production, meanwhile they were losing a lot of weight and wasting away so much. Overall we tried to find a better way, to take them to another community that would rent us the pasture, but we saw that it would come out very expensive for us. So we tried to negotiate and eventually ended the dairy cow project. - Heriberto (interview, December 12, 2009)

The dairy cows were not acclimated to volcano-side terrain, nor did they constitute an appropriate project for the resources available in these communities. Additionally, this project, like the chicken and pig projects, biodiesel, and candied macadamias were also deemed not only costineffective, but also a waste of initial investment. In the case of pigs and chickens, more money was spent on feed than was possible to recover through sales. Conceived as projects to generate income for women and provide a convenient source of food for the community, these projects ultimately cost more than they earned.

The problem is that, it's how we had to bring 100 chickens, and in the moment the 100 chickens have reached their weight you have to sell them. In the end there are many people in the community who say, "We have so many children we don't buy meat every day." So the chickens are ready, they're ready, and we are not selling, not selling. Finally, everything was going on credit. Everything on credit. So for that same reason we didn't see any earnings, for the reason that here it doesn't sell. We were going to other communities to sell, but it was very little. What's more was that they ate concentrado (feed pellets) and they were eating but the meat wasn't selling. So everything went on credit. Adelina (interview, December 12, 2009)

Residents were unable to purchase the chickens for sale in their community, leaving the project in debt and with no hope for recovering their losses. Similarly, the candied macadamia project results in a loss when the timing of supply and demand is miscalculated. 
Right now, the other scarcity, there is no [candied] macadamia right now because we shorted ourselves. Right now it's been a month that the hotel has no macadamia. And only a few bags if they sell them all at once, because if not, they're not throwing away any more macadamia. Because the problem that has happened here is that too much macadamia is thrown away when we don't have visitors. The macadamia gets ruined, it rots, that's its nature, right? It prevents me from going back to dry anymore because if there's no influx of tourists, they spoil. That's a problem, you know? - Domingo (interview, December 11, 2009)

Projects are revealed to be a poor fit for a community not only because of ill-conceived operating costs and sales projections, but also due to presumptions about "community" development. Projects introduced from outside the community frequently design operations around the concept of inclusion and collaboration, though this model of administration is not necessarily intuitive to community residents. Both the banana bread and chicken projects were intended to create a source of income for women. The banana bread project has been discontinued and restarted repeatedly, due to disagreements among staff regarding best practices, work schedules, and delegation of tasks. Similarly, the chicken project failed in part because of the inexperience of the staff in working collaboratively, as well as the lack of support from the men in their lives.

Well, but they haven't had the custom of working together, they had internal problems amongst themselves. But they are organized. The problem is that they don't have leadership that can also look for their own projects for their own benefit. And the other problem is that here the Guatemaltecos, well, are very machistas. So they don't give their women the liberty that we have... so that's something that they have not let them develop. They are afraid. - Timoteo (interview, December 2, 2009) 
It is a faulty assumption that the cooperatives of Alta Gracia and La Esperanza function like the typical coffee growing cooperative, which is comprised of individuals from a surrounding area electing to join a nearby cooperative and travelling to work together in a central location. Funding agencies often design projects in which residents come together to donate their time for the benefit of the community. Community residents, too, recognize the efficiency of collective development efforts. But in these cases, where the community is the cooperative, and vice versa, residents already have little option but to coordinate their daily work schedules. This is not necessarily by choice, but by necessity, and it is not easily accomplished.

It's so hard 'cause they're all at each other's throats. Imagine if you had to live in a little community of 32 families, and you're living next door to each other. That'd be taxing as far as I'm concerned... When they started out they were all fresh from the war, fresh with cooperative ideas and ideals. They used to cook together. Man, the stories they told about when they first got there, just kind of heartwarming... the infrastructure was not there so they used to sleep together, community meals, go out and clean the abandoned coffee fields, and since that time people have sort of, they need their space. So people are kind of backing away, backing away, backing away, and starting their own small businesses, like the stores that you see around Alta Gracia. The capitalistic entrepreneurship side of things is definitely taking over. I think they're moving away from that cooperative thing, which I would do, too. Because it would just be too much to be working and living [together]. -Jamie (interview, September 15, 2009)

In fact, each of the communities has experienced a fracturing, either of collective land holdings or the cooperative itself, evidencing the struggle for collaboration in a culture that has traditionally been individualistic and entrepreneurial. The case is particularly glaring in Alta Gracia, a community 
comprised of ex-combatants that once sang the praises of cooperative living but has since experienced crippling dissolution.

What happened is that you spend 30 years of your life as an individual and all of a sudden you're in an organization. Since the war we continue working at this, organizing the people to work in a cooperative. Because that's the solution we've seen in Guatemala. If we unite, we work the land better. We've heard from others in other countries, there's a sense of organization, but if there's no organization we work with many people from outside and we lose. Working together has many advantages. You can do the work better. There are always advantages and disadvantages, but in an organized community, everything runs well. -Francisco (interview, March 11, 2010)

The thing with Alta Gracia is that, it's just, there's no more community projects that go on. Really disappointing. Like when I was there they got the idea ... to have a community compost thing happening. And revolving funds where you get some funds to start the initial one and then sell it to the cooperative members for super, super cheap, and reinvest that money for the next year's compost thing. But it just ain't happening. People are doing their own thing. There's people that are going to buy compost out in town, most of the people don't compost at all, so there's just no community thing. And there used to be. There's all these projects that failed, chicken projects, failed. Compost projects, failed. And so everyone's just doing their own independent thing. Which for me it was like, oh, that sucks, but you know who am I to judge, really? - Jamie (interview, September 15, 2009)

Community volunteer work might be ideal in endeavors such as the organic vegetable or fertilizer projects, but it has proven too precarious to effectively staff the projects. Though it may be disillusioning for those development workers and funding agencies who idealize the cooperative nature of rural life, some have come to suggest a cooperatively-paid employee as supervisor as the only effective means of administration. However, individualism and job scarcity in these communities are such that residents are reluctant to privilege any single community member with a cooperative-funded position. As Jamie (interview, September 15, 2009) explains, "They pay one of 
the community members to do the processing of coffee during the harvest time, it's like a set job that he does and they pay him and that's cool. But other projects like that they insist need to be volunteer-based and stuff like that."

Furthermore, another reason residents have identified for project failure is insufficient investment. Celestino (interview, December 1, 2009) explains, "For example, here, the chicken project, we could try it again because it's very small, it's a very profitable project. But here it has not been invested in as it should be. Because l'd rather it [new development program] be a project that we've already had before. That would generate earnings." In fact, this sentiment that residents are weary of trying new projects was repeated by others. Historically, the approach to incoming development projects has been unconditional acceptance. With time, however, the attitude has shifted slightly, with some residents suggesting a greater investment in fewer projects.

Perhaps I think we could try at least one project but more than that and it's not profitable for us, not switching to another one. But we will see. Right now I say, fine. I think one, and two, and three, and then a pile, that's what happens here. ... So, I think it's better to have one or two projects, but take good care of them or take a lot of interest in them ... but if we have a pile of them we have already seen that it is not profitable. Because for example perhaps we have to go to feed the tilapia, but if I have to go to this project then I'm neglecting that one to take care of this one. -Heriberto (interview, December 12, 2009)

For my part, I have helped a little in the projects of our community. It would be better perhaps to slow down a little for the moment with the projects. One of my ideas. Maybe two or three while we are recuperating our cafetales [coffee plots]. And then we can continue with the projects because we already have somewhere to earn our money. But many of my compañeros are already thinking of tearing up our plots, our product. -Ovidio (interview, February 21, 2010) 
Not only does the inundation of development projects, especially in La Esperanza and Alta Gracia, too frequently result in wasted time, energy, and funding, but it also has a demoralizing effect on residents. The abundance of new projects has diminished overall enthusiasm, with residents taking new opportunities for granted and reacting with apathy when they fail. Several residents expressed appreciation for outsiders' visits if only because they dar ánimo, or encourage and generate enthusiasm, for the works in progress. Finally, disappointment eventually settles in after repeated unsuccessful attempts at building an effective and self-sustaining program. As a result, residents have a lack of confidence in their ability to improve the community for themselves, preferring that outsiders advise them on what they need.

If you can tell us the bad things you've seen in the community, because obviously we believe that we're on track but we haven't arrived at the goal we want. So I think that with you visitors, you are witnesses that can notice the little good and the bad that we have here. And you have to leave us with your word so that we can go correct it because if you don't tell us what we have done wrong we will continue to think everything is alright. Everything in life is going to be alright. So we need you as visitors who see things to explain to us and leave us with recommendations so that we can, like I always say, we are always moving ahead or always trying to improve, always getting better. But how we get better is that you tell us the bad that we have. -Heriberto (interview, December 12, 2009)

\section{BEHIND THE MORE SUCCESSFUL PROJECTS}

As demonstrated above, those developments that are most appreciated by the community as beneficial to their wellbeing have typically been reinvestment in existing projects, such as coffee production, bottled water, and schoolhouse improvements. Though less attractive to potential funders who 
prefer to leave their mark with a unique, trademark project, bolstering a few focal programs in the community has proven a wiser investment of resources and energy, as well as a more satisfying use of funds for the recipients of development aid in these communities.

The development goals cited by community members reflect past development successes. Though new income-generating activities represent a significant portion of attempted development projects, they are the least commonly-cited goals of residents. This contrast is in part due to the fact that the new projects are generally previously unheard-of activities; respondents occasionally stated that, in general, they would like a new project, though they did not have a specific activity in mind and would be open to trying anything proposed.

Respondents' more often cited development objectives reveal an emphasis on reinvestment in already-existing projects and resources. By far the most common goal was reinvestment in coffee production, citing ways in which development efforts could be well spent. These suggestions included trainings for more effective coffee handling, increasing production volume, entrance into new specialty markets, increasing coffee quality, purchase of onsite processing equipment, and materials for self-generating inputs such as seedlings and fertilizer. In addition to coffee production, respondents also held goals of improving tourism projects through better facilities and trained staff, expanding the capacity for macadamia sales through purchase of equipment such as a refrigerator, and investing in new delivery vehicles. 
Outside of productive reinvestment, residents expressed most interest in developing community infrastructure, especially in health care, education, and sanitation, including improved drainage and potable water systems. Development in these areas would not only improve the quality of life in the community, but also provide relief for household budgets, where education often comprises the most significant expense just after food, and an illness can leave a family in financial ruin.

Following health care and education, respondents were most concerned with the fate of future generations. After securing education for their children, many respondents have watched their children struggle to find relevant employment, forced to choose between abandoning their community for the city or returning to coffee production as a well-educated campesino (peasant or farmer). To parents, off-farm employment is generally viewed as unreliable and unpredictable. Coffee cultivation, on the other hand, is perceived as a safety net that must not be deserted by future generations. With one notable exception, a skilled laboring resident who married into the community, all respondents stressed the importance of maintaining coffee plots and remaining attached to the community.

Well, that is a question that many parents ask. Many parents ask because the children are leaving to study, right? And so they say, 'Well, what is going to happen with the land? Our children leave and what will happen with the land, then?' And they are right. However, in the school I say to the children, 'Look. Prepare yourselves. Improve yourselves. But also don't forget the little piece of land that you have. Because not everyone has the opportunity to have a piece of land to work. So if in the future you have a job and have a piece of land, you can't abandon your land. You are going to have a job, you are going to have a salary, then also work the land.' -Bethania (interview, February 10, 2010) 
But if they already feel like someone important with better education they have the possibility to leave for another place, because why not tell them, 'If you get your Masters' in engineering or become a doctor or nurse... they can leave and work outside and pay someone who will work their land. Because that is also very key, and for that they will also need to study and become someone important, and become someone who serves their country. -Heriberto (interview, December 12, 2009)

The most unanimous goal held by residents in all communities was that children get an education so that their lives would be easier and they would have options for employment, with the understanding that they remain rooted in and continue to support their family as well as their community. To make this goal a reality, residents need access to affordable education, as well as a means of rendering coffee production a lucrative livelihood choice.

\section{FAIR TRADE AS AN AGENT OF DEVELOPMENT}

Education, health care, and other forms of infrastructural development are precisely the types of projects that the social premium for Fair Trade coffee is intended to support. In addition to the Fair Trade minimum price, producers are given a social premium to be used in the community development project of a cooperative's choosing. However, it will be shown later that these premiums are not always used in such a way. Neither are all members of the fair trade movement convinced that social premiums are a sufficient resource for producers to accomplish their development goals.

Recalling the original approach to fair trade as part of the alternative trade movement, some purchasers aim to provide the additional support that producers need in order to realize these goals. 
And so part of what we do, I mean, I've always looked at Roundtable Roasters as, on one hand we're a business, and we do this buying and selling coffee, and it's important to pay a good price and have good relationships. But on the other hand, it's also helping as much as we can to help communities and coops make connections and to be able to work on sort of their larger development goals that they're never going to be able to cover just making a premium on their coffee. It's just not gonna... and so the best case scenario, I think, with Alta Gracia or any of the coops we work with, is that we can pay them enough money that they can pay their bills and start to invest in something else and then hook up with other organizations who have connections to be able to realize those things and be able to diversify. -Kenneth (interview, September 11, 2009)

While producers' opinions of Fair Trade certification vary by experiences and expectations, they were solidly appreciative of the support they received in the realm of social development. The active role that producers play in identifying projects for their communities is likely to explain the high level of satisfaction that coffee producers express for the development support they receive from fair trade partners. Unlike many of the foreign governments, NGOs, tourists and other visitors to coffee growing communities, fair trade partners offer materials and services requested by the recipients, as well as funding to be used in projects of their design. Whether through Fair Trade certified channels or though their partners in selling relationship coffee, social development is one form of support that producers unanimously valued.

Residents in these communities have grown accustomed to disappointment in development assistance. Too often, projects have proven unsustainable in the long-term. This may be due to a lack of human capital necessary to maintain essential components such as computers in a computer 
lab or engines in a biodiesel converter. Another common cause is cost inefficiency, as in the case of the livestock projects that seem to be introduced without assurance of either available food sources or dependable buyers. These disappointing results can often be attributed to the brevity of support and the introduction from outside of projects that are not communityappropriate.

The nature of fair trade, on the other hand, is designed to address both these characteristics of ineffective development efforts. By establishing longterm trade relationships, fair trade purchasers have continued involvement in producer communities. The objective is to initiate development projects without serving a pivotal role in its long-term success, as staff or a source of funding, but to be available for consultation and project evaluation over the course of the project's lifespan. Contact may be frequent and in-person or it may be annual and indirect, but in either case, the source of support has ongoing communication with producers, receiving updated information regarding the status of projects and offering advice when solicited.

Additionally, fair trade is intended to address the cite-specific conditions of production and trade. An additional consequence of a shorter commodity chain is the effect of bringing producers and purchasers closer together, revealing the previously obscured context of production. As one Alta Gracia resident explained,

But fair trade, the cooperative that buys our coffee, they've been here. They've seen the process up to drinking a cup in the US. And they said that people act like coffee comes out of thin air. But no, it is a long process for the farmers. For example, when I plant a new plant I have 
to wait three years for it to produce. So they have been here and said that, "No, you deserve a fair price." -Francisco (interview, March 11, 2010)

In recognition of this grand process, fair trade purchasers may offer more than just a fair price. They may also offer supplies, trainings, and investments in infrastructure that they recognize as sorely lacking in the producer community. In this way, fair trade partners are in a position to tailor development support to producers' specific needs and cultures. This is in stark contrast to the practice of introducing to communities new projects with which residents have neither experience nor self-generated interest. Furthermore, greater attention to local context obviates some culturally insensitive elements of design, such as projects designed to be collectively or cooperatively staffed.

To resolve the inadequacies of failed development projects, Dean Cycon promotes a "people-centered development" approach. Speaking from his experience visiting and collaborating with coffee growing cooperatives, Dean explains his approach as follows:

People-centered development is an approach to international development that focuses on the real needs of local communities for the necessities of life (clean water, health care, income generation)... We are committed to small, meaningful projects that the community actually wants, and that are sustainable over time without our continued involvement. First of all, we only do projects when asked and invited in by the community, not by the government or some large foreign aid agency. When we visit, we talk to the farmers, women's groups and other about what the biggest problems are in the community. Then we talk priorities - theirs, not ours... We then work directly with the community to design a project that will address their expressed priorities. We try not to bring in outside (or even local) organizations if the people themselves can manage the project... We are also in contact with our farmers by email and visits year round. This way, we can offer advice and strategic planning on all sorts of important issues. (Dean's Beans N.d.) 
By deriving project ideas from cooperative members, basing the design upon the community-specific characteristics, and offering long-term consultation, fair trade partners have been involved in some of the more successful development projects in these communities. Consequently, social development benefits comprise the aspect of fair trade with which producers seem most overwhelmingly satisfied.

Fair trade members are not only in a unique position to offer development support that is specifically designed for the needs of grower cooperatives, but as long-term trade partners they are also vested in the growth and success of their suppliers. Whether a project made possible through use of the FLO premio (social premium), a donation of supplies to invest in the community, or recovery assistance in a time of crisis, the greatest advantages to fair trade may lie outside the trade itself.

\section{Direct investment in production}

Many of the above-mentioned organizations have introduced new income-generating projects such as livestock-raising and biofuel production, which have rarely met with success. Instead, the beneficiaries of these projects frequently ask for greater investment in the projects already in place. The coffee roasters in the relationship coffee system as well as the purchasing cooperative in the Fair Trade system have contributed much needed investment in coffee cultivation in the form of staff, trainings, and supplies. For the donors, this is also an investment in the future of their own organizations, as successful coffee production generates more product for them to purchase 
and sell. For the coffee growers, this is an investment in the future of their community, bolstering the viability of their livelihood with materials and education that would they have not been able to access on their own.

Most, if not all, residents in these communities would agree that they are not working their land to its maximum productive capacity. The cost of inputs such as plants and fertilizer as well as the labor to engage them prevent these coffee growers from fully cultivating their land. As Don Rodolfo (interview, March 15, 2010) explained,

The land is a natural resource you have to take advantage of, and that requires money. You have to renovate, plant, and that takes money. You have to fertilize the land, and all the work it requires. If you don't have money, you can't do it. Land well-worked with good technology produces, and you make money and improve your living conditions. But if you don't have money or training... We have land and a market, two important things, but we lack money to work, financing.

As a result, some producers employ all their land in coffee, but with minimal plantings. In Alta Gracia, no alternative crops have been developed since disease decimated the majority of their banana trees. Of their allotted 30 cuerdas per household, residents reported a median value of 28 cuerdas dedicated to coffee growing. In the case of Don Francisco (interview, March $11,2010)$, everything is planted in coffee, though, as is common, production is not as effective as it could be.

Thirty [cuerdas]. All of it is planted in coffee. Not a lot, but yes. The problem is that there hasn't been any money to put into thirty cuerdas. There should be a lot of production, but you have to invest. That's the primary factor. Because if you have money, of course you're going to buy food [rather than reinvest].

Others producers opt to focus on a portion of their land, either leaving the remainder uncultivated or employing it for another use. In Bella Vista, 
though the average resident surveyed claimed 33 cuerdas of land, only 17 cuerdas were employed in coffee production. Additional land holdings may be deemed too steep or heavily wooded for cultivation, or they may be assigned to pacaína cultivation, a decorative plant that can be sold for a meager perbulto (bundle) price year-round. La Esperanza residents are set to receive over 50 cuerdas per household once the distribution of land is complete. Of these, residents surveyed claimed 47 cuerdas dedicated to coffee, however this distribution is largely by design of the former landowner. Maintenance will require significant investment from the new land title holders, and already their coffee production is hampered by overgrown macadamia trees which furnish a significant part of their year-round income.

With more terrain than finances permit to be effectively cultivated, producers welcome any contributions to land development. In addition to the government support available through the Fondo de Tierras and Anacafé, fair trade partners have been a significant source of investment. For example, after Hurricane Stan destroyed many of the community's already aging coffee plants, residents quickly identified replanting as a top priority for community development. However, the major economic losses that resulted from Stan only worsened their already low production volume, leaving no expendable income to invest in new plants. Furthermore, organic coffee plants can be difficult and expensive to acquire. Fortunately for residents, their fair trade partners at Roundtable Roasters helped put the community in contact with Catholic Relief Services (CRS), "the official international humanitarian agency 
of the Catholic community in the United States." To bolster coffee production, residents in Alta Gracia received assistance to construct an almácigo, or nursery, for coffee plants.

We've been talking to CRS for a few years about various projects, trying to get various projects going down there. So through Cooperative Coffees and with Roundtable Roasters we've had a lot of dialogue with CRS, and they had a project last year that they were thinking about doing with them, and it just didn't work, but it really got Alta Gracia on CRS's radar. So this guy Michael Sheridan who's down there right now, he's CRS's dude in Guatemala, and he's been working pretty closely with them, and he's a good friend of Roundtable Roasters'. He's been here a few times and we've been together with him at coffee conferences in Guatemala. So we kind of hooked them up. -Kenneth (interview, September 11, 2009)

These connections made through Roundtable Roasters and Cooperative Coffees resulted in the donation of a community almácigo that housed 30,000 seedlings as well as funding for one salaried staff person.

CRS (Catholic Relief Services) is paying Don Félix. When CRS came, there was no almácigo. He didn't work there. We didn't have any workers for the cooperative. Everyone did their own almácigo. If I didn't have money, I would buy 500 plants or I would do it here. But everyone did their own. There wasn't anything like this, collective. Now, because of CRS, Don Félix is working. -Rodolfo (interview, March 15, 2010)

Each household in Alta Gracia received donations of upwards of 1000 seedlings for planting in 2009 through this CRS connection, additionally supported by a connection Roundtable Roasters helped to establish with the student group PRIDE from a North American university. One resident explained, "For example, this year we planted 1100 [seedlings] from CRS and the students gave us each 800 plants. So we almost planted 2000 plants. And CRS gave us abono, too. So there are some, the plantation looked really nice. My land is beautiful with plants. So I think that for this year to next year we will 
have more coffee, because the plants look good. The next year the plants will produce coffee." As a result, while surveys revealed a median value of 1400 seedlings planted per household in Alta Gracia 2009, residents reported a mean and median of $O Q$ spent in the purchase of seedlings for that year. The majority of cooperative members expressed appreciation for the donation of plants with comments such as, "We are happy to have the plants. Very happy with our plants. Yes, there is hope for the production of young coffee plants." (Francisco, interview, March 11, 2010) Considering the retail value of coffee plants, usually around $1.50 \mathrm{Q}$ per seedling, depending on the variety, this donation has a value of around $2100 \mathrm{Q}$ per family, a significant sum that they would not otherwise be capable of investing.

Residents in Bella Vista, too, received in 2009 a donation of 100 plants per family from FUNDAP, a Guatemalan non-governmental development organization. This connection was fostered by Toro Verde, who helped distribute the plants in the community. Though plants were made available to members of both groups, some Grupo Convencional members declined the offer out of mistrust of the umbrella cooperative. In Grupo Organico as well as Grupo Convencional, residents reported planting an average of around 260 plants in 2009. Members of the former group, however, spent an average of $320 Q$ in the purchase of plants in 2009 , while member of the latter reported spending over twice as much, an average of $784 Q$, on seedlings.

The residents of La Esperanza, too, have experimented with a community nursery, here termed a vivero, though their project preceded their 
participation in the Fair Trade system. Donations funded the purchase of materials and construction in 2008, and the cooperative paid wages for two vivero workers for the duration of the project. While the vivero was considered a successful project that produced healthy, robust coffee plants that could potentially be sold to neighboring communities as an income-generating project, the individualization of land holdings led cooperative members to distribute the seedlings amongst themselves and disband the project, returning the plot to the cooperative holdings for inclusion in the land distribution lottery. Due to the success of the vivero, residents in La Esperanza reported a median value of 950 seedlings planted in 2009 despite a median value of $O Q$ spent in purchase of plants.

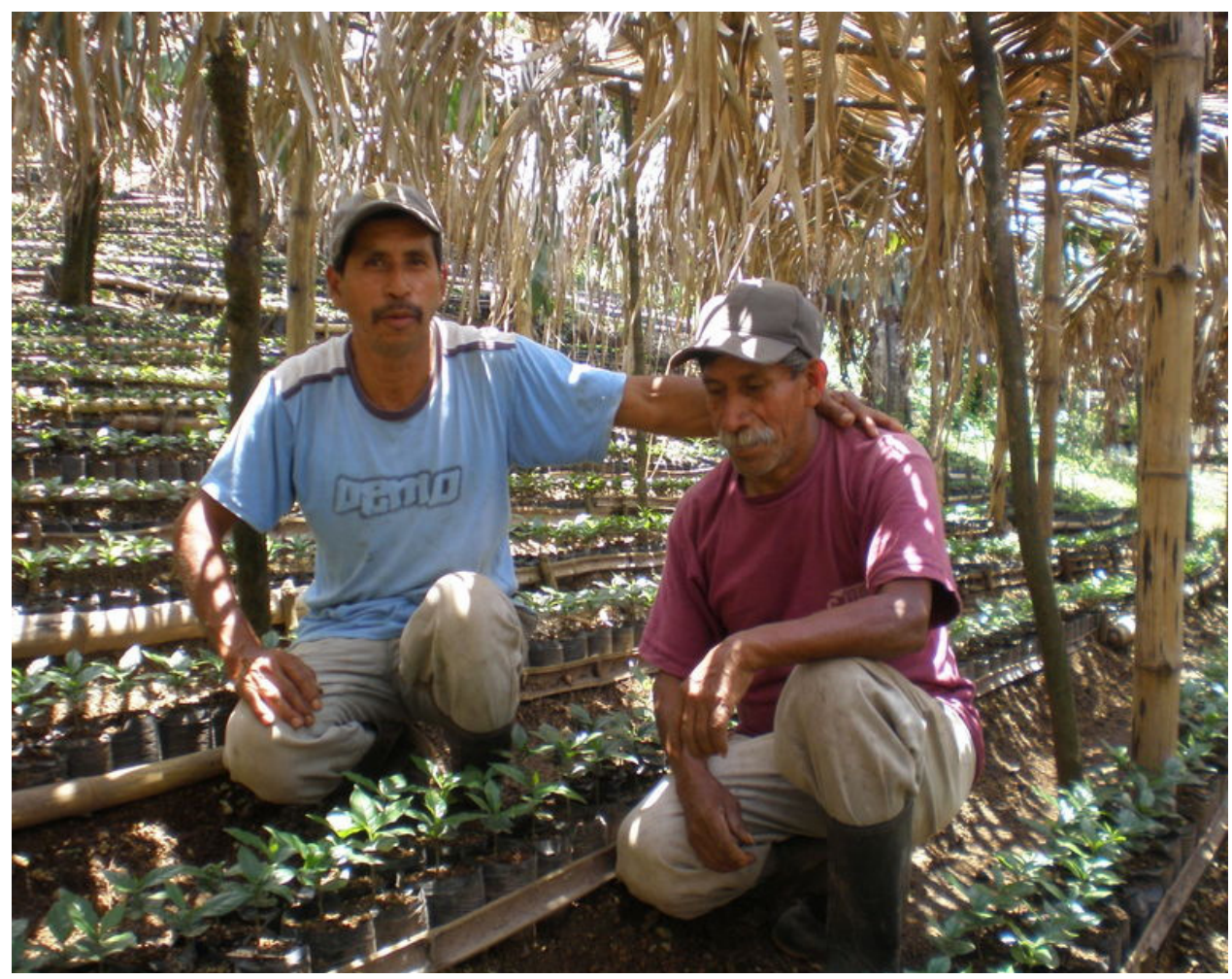

Figure 6.4 Paid staff of the vivero in La Esperanza 
All three communities have received further direct investment in production to produce their own organic fertilizer. Another facet of CRS support in Alta Gracia includes the construction of a lombricultura (vermiculture) facility, in which coffee pulp is deposited in layers, consumed by coquetas rojas (red wigglers), and transformed into nutrient rich fertilizer to be applied directly to coffee plants. Additionally, the sumos, or liquid waste from the worms, are collected and applied as an abono foliar, or a type of fertilizer sprayed directly onto the leaves of the coffee plant.

The abonera (composting facility) project in Alta Gracia is relatively new, established in 2009, and its long-term success difficult to gauge. However, if the outcome is at all similar to that of Bella Vista, it will provide a tremendously productive and cost-effective resource to the community. Bella Vista's lombricultura project was established in 2006, funded in part by Anacafé and Toro Verde, and has since grown to occupy two separate facilities. The Grupo Organico cooperative has maintained a single staff person since the project's inception, and is now able to offer to community residents organic fertilizer at a subsidized, "symbolic" cost of 20Q per quintal, a significant savings over the local going rate of $80 \mathrm{Q}$ per quintal. 


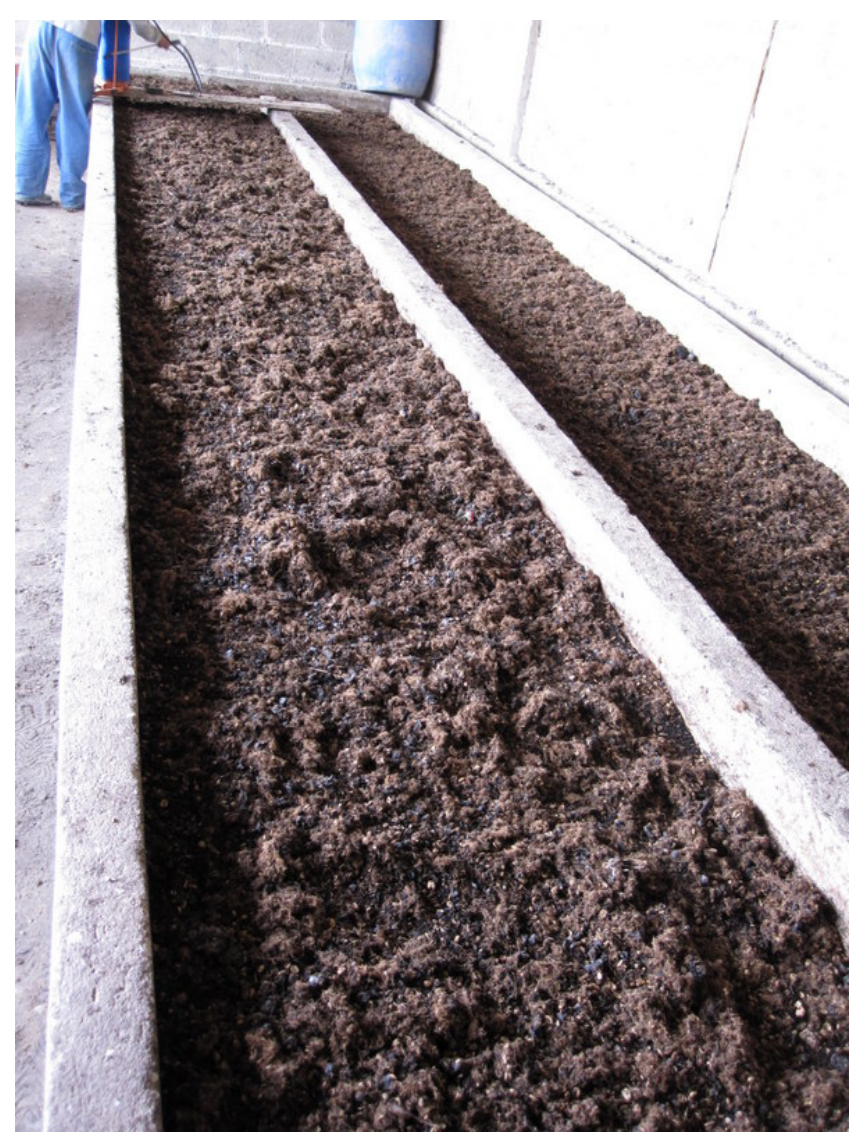

Figure 6.5 Abonera (fertilizer production facility): Piletas (basins) of lombricompost (vermicompost) in Bella Vista's highly successful abonera

In the case of La Esperanza, abonera materials and supplies were donated by Anacafé and maintained through trainings with Semilla Nueva (New Seed), a Guatemalan non-profit organization that promotes sustainable agriculture development. The project was regarded as highly successful, producing not only abono and sumos but also various types of control biológico, or organic pest control, including oriajo, chileajo, and chiltepol, mixtures of animal urine and garlic, chiles and garlic, and juice from chiltepe chiles. Rather than provide these materials for community use, however, the abonera in La Esperanza was conceived as an income-generating project to supply neighboring communities. As a result, La Esperanza's abonera can be 
viewed as more an income-generating project than an investment in the production of the cooperative.

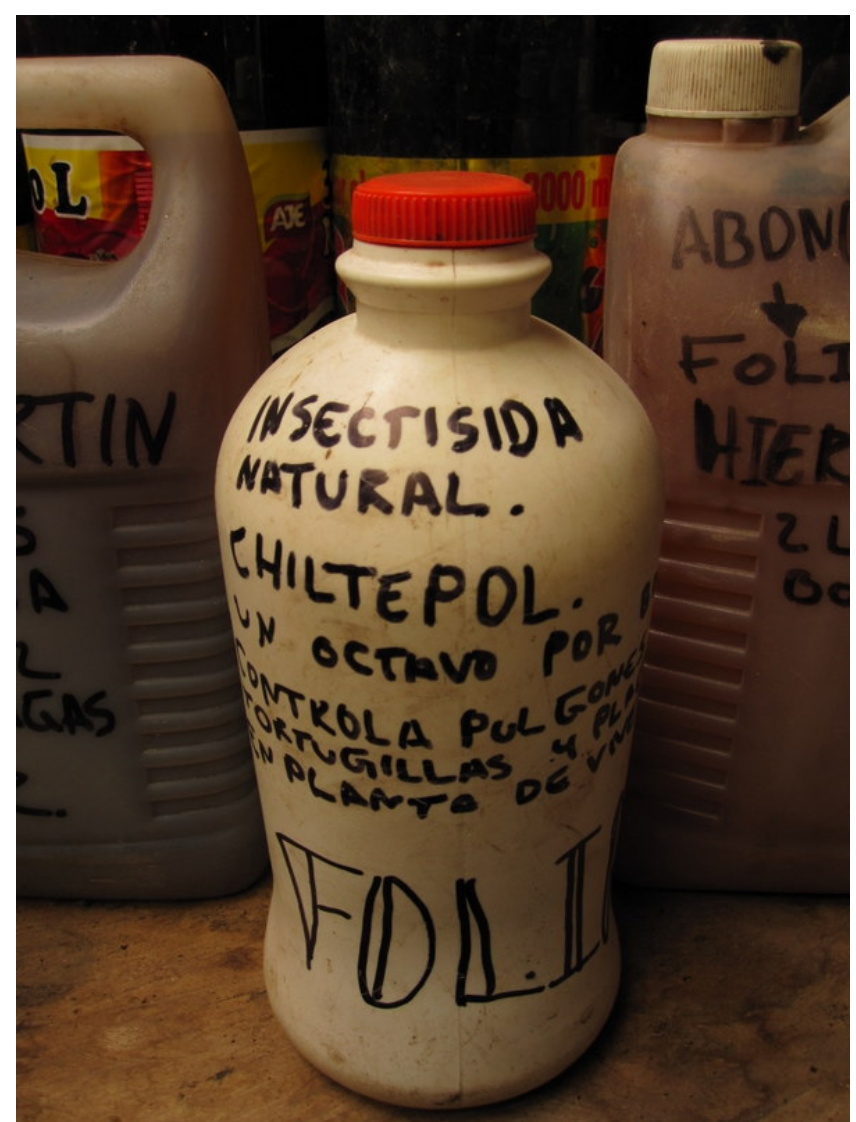

Figure 6.6 Chiltepol: an abono foliar produced in La Esperanza's abonera project

Unfortunately, the abono production was disrupted in 2010 due to a conflict with the single trained staff person. Although a new staff person was eventually assigned to resume the project, the transition occurred too late. Left for weeks without a staff person to feed them, all the worms starved to death. Upon a last visit to the community, the project was no longer active. For the abonera project to resume production, the community would require both an entirely new supply of coquetas rojas and complete training for the new staff person. 
Investment in human capital

In addition to the direct donation of supplies and materials, cooperative members received through the fair trade network training to advance their knowledge of coffee production. This has been particularly important in Alta Gracia, where the majority of residents are learning for the first time the skills they need to be effective in their primary income-earning activity. As one resident explained, "We haven't had good consultancy, either, because to have consultancy, an agronomist comes, and you have to pay for that. Right now we have someone from CRS that our purchasers sent here. By means of them, he came." In Alta Gracia, residents are in need of training in each stage of production, from growing seedlings to identifying and treating coffee diseases to effectively staffing the beneficio. Kenneth (interview, September $11,2009)$ explains the importance of the training that residents have received from CRS with help from Roundtable Roasters:

Just being a cooperative that hasn't been around that long, Benigno will always tell you that "We're not farmers. We're not farmers," or "We weren't farmers." And so a lot of those guys maybe came from some farming community, but generally most of them didn't come from coffee backgrounds. And then the adults were fighting or else refugees in Chiapas for 20-30 years. So that knowledge that we see in a lot of coops, which is coffee growing passed down through the generations, they didn't get that. So they have a pretty serious challenge in learning, technically, how to not only grow coffee, but how to grow organic coffee and how to navigate the organic and fair trade community... So the other thing we want to do is be able to connect them with other organizations that can help them work on their development goals. And there's a lot of good groups down there right now, like PRIDE from [name omitted], who are really - we're really good friends with those guys. And Catholic Relief Services has just given them a really big grant, and that's gonna be huge, because their production is just going to skyrocket. The stuff they're doing down there right now is amazing. Just all the grafting and making their own compost now. And they're 
putting in tens of thousands of new plants... It's a three year project. They've got a guy who's in the community who - I think he's there five days a week - and he's just trying to help them improve practices while at the same time he or CRS has money to buy new plants and pay for grafting and just pay for some of the material of things that need to happen there. So it's a three-year grant. It's tens of thousands of dollars, which is really nice.

Residents of Bella Vista also benefit from capacitaciónes, or workshops, to further their knowledge of coffee disease prevention and treatment as well as best practices in the beneficio. Trainings here are provided by several different organizations, but primarily Anacafé, Toro Verde, and FUNDAP. Capacitaciónes given by Anacafé have been greatly beneficial, informing attendees of best practices in pruning, fertilizing, and financial management.

There they are about working with coffee. They are about how to build an almácigo, how to plant, how to dig holes, and when the plants are big enough so that they will not continue growing in order to trim them despunte, how to work so that you don't lose too much of the plant. And later, they are about what is called descope (pruning), when the plant has already given its product and so you remove a part of the plant so that new branches come, you begin to work with this. And later, how to prune when you cut the plant so that new growth comes. How to eliminate shade. How to fertilize, only learning to work in coffee cultivation. Also with Anacafé, I participated in getting my diploma in Agricultural Administration. It's how to administer a coffee plot. It's how to see, really, if what I am investing in the coffee plot is coming back or not anymore, it requires a register with all the tasks, and that is how to determine if I am really earning by working in coffee or if I'm not earning anything. It's to administer everything I'm going to put into the plot and what the plot is going to give to me. It's to keep this in balance, right? And about tasting, that is on behalf of Toro Verde. I have received that two years. It was only one day, because to receive the full class takes several days. So they only gave us the most important information on tasting and nothing more. -Eugenio (interview, January 23, 2010)

While the capacitaciónes offered by Anacafé are exceedingly helpful to those who receive them, these trainings are primarily made available to 
elected representatives in the Grupo Organico Board of Directors and hired employees of the beneficio. Trainings offered by Toro Verde, however, are for the benefit of all cooperative members and treat similar themes.

Sometimes they [Toro Verde], or sometimes you hear that it was with Swiss cooperation that they were working, that they come with capacitaciónes for the Directors and cooperative members in technical assistance and, in the last two years, coffee tasting. Yes. They help us with something to build a nursery, to make compost, bokashi, but we haven't finished this project yet, and also they came with money to buy for us our first kilo of fertilizer. Now there is plenty... They have trained me, and I really enjoy the capacitaciónes. I have been trained a lot with the church, with Toro Verde, with the Pastoral de la Tierra [agricultural development organization of the Catholic church in Guatemala involved in the founding of Toro Verde]. -Cristóbal (interview, February 2, 2010)

Moreover, the information shared in capacitaciónes is perpetuated through the system of promotores required as part of organic certification through Toro Verde. These individuals are elected to patrol the coffee plots and make recommendations based on their knowledge as trained experts in best cultivation practices. As one former promotor stated, "I know everything from when the plant starts growing up to the grain of coffee." (Efraín, interview, February 4,2010$)$ It is the responsibility of the promotor to ensure that cooperative members are taking the best care they can of their plants and to notify landowners of improvement that can be made. The promotor serves as a preliminary screening for organic inspections that occur annually, and it is through them that the information that cooperative members receive in capacitaciónes is reiterated and reinforced.

The promotor works in the coffee plots. How to cut down a plant that is already too old. How to dig the holes, how apply the fertilizer from the worms. It is management. All management of agriculture. Say that here is the promotor and you are owners of land and he brings you to do 
some work, something is missing and this is like a motivator, something that requires a space, and I want to see the work. It is already done, what I am telling you from the recommendations that they give you. So you begin to work well with the promotores. That is the work, we have people who care for the coffee plots for us. Yes. Those who are landowners in the coffee plots also receive information, they get a list of the good and the bad in their coffee plot. -Cristóbal (interview, February 2, 2010)

Grupo Convencional does not, however, employ the promotor system. Consequently, this is viewed as one of the primary benefits to Grupo Organico participation. Residents consider Grupo Organico to be more organized and supportive of one another that the more individualistic Grupo Convencional. One member explains:

Mmmm I think that they [Grupo Organico] are more united, more than anything. That's how I see it. I don't know if it's true. There isn't envy. They help each other. The old people tell you, for example the other day, in my case, an old woman in the Grupo Organico told me, "Your shoots are looking really nice, but you had better go weed it, because the vines are taking over." I told my papa the vine has already started to climb the shoots, so this week he cleaned it. So the older people tell you if they see something in your terreno. -Catalina (interview, February 20, 2010)

Likely a remnant of the former dueño's (owner) system to which they had grown accustomed, La Esperanza already had a similar system in place prior to their participation in the Fair Trade system. Four elected representatives to the Agricultural Committee monitor the condition of coffee plots in the community and report to the general assembly. As one resident explains,

There is an Agricultural committee that is dedicated to the finca, and they give recommendations if they have them, then in the meetings they are discussed. They have meetings and there they tell people that they have to do things in this way or that way or another way... how to improve the quality because quality begins in the coffee plot up to the process of picking." - Celestino (interview, December 1, 2009) 
Now that the cooperative land has been individualized and the cooperative has resumed participation in the conventional system, the fate and function of this program is unknown. Whether the Agricultural Committee will continue to monitor and make recommendations to individuals remains to be seen.

\section{Direct investment in the community}

The social benefits of participation in a fair trade system are not limited to investment in the cooperative's productive capacity. By virtue of the closeness of their trade relationship, fair trade producer groups may also receive support for aspects of community life that are not necessarily related to coffee production.

In Alta Gracia, children are able to continue their education beyond básico (beyond grade 9) thanks in part to donations from Green Thread and Roundtable Roasters, their past and current coffee purchasers. Extending their support beyond production-related goals and into general community wellbeing, these organizations donated to the community a van to drive children to and from carera or diversificado (high school level) institutions in neighboring cities. This provided a more cost-effective alternative to paying bus fare to and from school each day.

Moreover, the residents of Alta Gracia received significant financial help from their roaster in the wake of Hurricane Stan. While the Fair Trade system, in which Alta Gracia still participated at that time, persisted in the imposition of new inspection fees to cover FLO-Cert Ltd. services, which struck residents as 
rigid and insensitive to their crisis, Alta Gracia's purchasers, on the other hand, were not only forgiving of the disappointingly low quantity of coffee for sale in that year (a situation which, in a more temporary trade agreement could easily result in abandonment of the producer group in search of a bigger purchase), but fundraisers were held in the name of the community to compensate residents for lost income and supplement additional costs of recovery. Below is an excerpt from a promotion for a fundraiser held by Just Coffee, a member of the Fairtrade Federation, for one of their partner producer communities affected by Hurricane Stan:

During his visit to the United States, organized by our compadres at Just Coffee in Madison, Wisconsin, the community's director of commercialization Rigoberto Augustin Ramirez, explained the nature of the community's current financial crisis. He also articulated his community's unwavering commitment to the concept of Fair Trade and determination to overcome their present circumstances no matter the sacrifice he and his fellow coffee producers have to make. It will be another 18-24 months before the community at Santa Anita will see its coffee production and income return to pre-hurricane Stan levels. In order to get there, it is imperative that the community move forward with this year's harvest, which they will do with or without the help of others - their community's future depends on it. However, the members of the community do not feel that it would be responsible of them to seek out loans to remedy their current financial crisis given the precariousness of their income stream for the foreseeable future. Because of our close relationship with the members of the Santa Anita community, their evident commitment to fair trade and transparency, we agree with them that what they need right now is a capital contribution. All of us at Just Coffee and Café Campesino think that we and our network of friends and family can and should do what it takes to help the community raise the capital they need to get working on this year's harvest...time is of the essence though...the coffee is ready to be picked. ...We have set up a Santa Anita Relief Fund so that our friends at Santa Anita can get back to work, which is all they really want to do anyways. ...Please note that should we exceed the fundraising target, the excess will remain in the Santa Anita Relief Fund for the community to use for medical emergencies and critical health care for members of the community. (Earley 2006) 
In Bella Vista, too, the community received support from the Fair Trade certified umbrella cooperative, Toro Verde, to repair damaged infrastructure:

Yes, in the time of Stan, Mitch, and all that disturbance, they helped us with tubing, because they were broken where our potable water comes from, the tubes where it flows down. There were landslides because of all the rain. So they gave us some. They helped us with this barrier, to reinforce it so we could go to change the tubes. They went to the tube in the ditch and had to put in a new one. So, yes, we have received help. -Cristóbal (interview, February 2, 2010)

As mentioned earlier, governmental support in such rural areas as coffee plantations are frequently located is often slow in coming, if it comes at all. Close contact with fair trade partners allows coffee growers to communicate their needs and receive assistance to make necessary infrastructural repairs in the absence of governmental attention. Additionally, a reserved community development fund as intended by the social premium would provide cooperative members with the resources to independently address such urgent needs such as road clearings and drainage repairs.

\section{Indirect benefits}

In addition to financial and infrastructural investment, producers benefit from several unanticipated consequences to participation in a fair trade system. An earlier discussion of direct investment in coffee production revealed networking as one of the key advantages to maintaining such close relations between producer and purchaser. Though Roundtable Roasters was not directly able to address Alta Gracia's need for reinvestment capital and supplies or cultivation assistance, they identified a development organization 
that was prepared to provide the support needed. As a result, Alta Gracia received the materials and training both they and Roundtable Roasters identified as desperately needed for the future growth of the cooperative. This expansion of producers' social networks into broader development organizations is a significant benefit, as it allows producers to establish new relationships and pursue development assistance independent of their trade relationship, relieving for both producer and roaster some of the pressure of dependence on the coffee purchaser.

These broader networks can also extend beyond simply identifying sources for development aid by generating support for other incomegenerating endeavors. This is especially true in the case of ecotourism projects in all three communities. As cooperative producers of fair trade coffee, these communities appeal to students, volunteer tourists, church organizations, and other classes of traveler who are interested in the impacts of certification and first-hand experience of life on a coffee farm. In the case of Alta Gracia, Roundtable Roasters organizes annual "delegations" in which interested travelers can pay to accompany representatives on a community visit. Bella Vista, too, has drawn travelers to its nascent ecotourism project in part because of their visibility on coffee retailers' websites. Since the inception of their tourism project, La Esperanza has promoted itself to tourists as a fair trade cooperative, even before receiving FLO certification. For all three communities, their status as producers of fair trade coffee adds intrigue for travelers who are familiar with the term and eager to see for themselves the 
reality of "fair" and "unfair" coffee production. In this way, they are able to distinguish themselves from the numerous coffee tours available in Guatemala. As a result, the communities in which cooperatives are located receive additional revenue from visitors in the form of room and board. Furthermore, the fair trade system begets additional networking, as these visitors often pledge continued support, connecting the communities they have visited to additional development organizations with which they are acquainted.

These connections may endure beyond the cooperative's purchasing relationship. Although Green Thread had to discontinue their purchasing relationship after Alta Gracia's forfeiture of Fair Trade certification, they continue to support the community through the "philanthropy side" of the company in an effort to "[reinvest] in farms that are actually putting beans in our bags". While they cannot financially support the cooperative though the Fair Trade system, they continue working with the community to generate development goals and projects. As one representative explained:

In the past, the last year and a half, it was really going and having to convince them that we're not there to buy coffee, and have a list of questions where we're trying to get them to help, trying to help them understand that we're here over a period of time, and then start asking for things like business plans and community need plans. Most have never had those, so the process would be, "Alright, what does that look like?" and have them start developing those things. -Brenden (interview, September 17, 2009)

Finally, this highlights yet another indirect benefit of participation in a fair trade system. By collaborating with fair trade members to identify development needs and suitable funders, producers learn valuable lessons 
about designing proposals and business plans. In Alta Gracia, for example, student representatives from the PRIDE organization a New England-based university conducted a survey of resident households, collecting information regarding average annual incomes, monthly utility costs, and average amounts spent on various categories of food items. The resulting document, demonstrating economic and development needs in the community, can now be used by administrators in the composition of grant proposals and aid requests.

Silver bullet or silver lining?

The projects resulting from participation in the fair trade system are discussed favorably in producer communities. To cooperative members, they represent investment in the future, both for coffee growing and beyond. Inputs and training raise hopes for more bountiful future coffee harvests and, subsequently, greater profits for member households. Expanded social networks open doors to new development resources and equip residents with the information they need to design and propose projects of their own. Furthermore, auxiliary support of education prepares upcoming generations for greater employment opportunities in addition to coffee growing. For coffee growers in a fair trade network, these social benefits help compensate for disappointingly trivial economic impacts.

But the unique characteristics of the fair trade approach to development, based on closer and more enduring relationships, do not guarantee the "success" of a project. While projects linked to the fair trade 
system tend to fare better than those introduced from outside or supported only in the short-term, these projects have also produced mixed results. A large part of this "failure" can be attributed to internal issues within a given community, which even the best-conceived project will struggle to overcome. In fact, in some cases, the closeness of the relationship between producer and purchaser can be viewed as too close, where the purchaser has become so deeply embedded in the social reality of the community that it begins to hinder both effective development and the trade relationship itself. Another aspect of this "failure" in the eyes of the recipient can be attributed to the conference of too much assistance, wherein so many resources and development efforts have been introduced that producers become overwhelmed, thereby exhausting their productive capacity and devaluing the significance of the support. Finally, in the case of the premio, the disappointing economic benefits of Fair Trade have sabotaged the feature with greatest potential to benefit producer communities. Though the development efforts of fair trade members may be better designed compared to those of other agents of development, and though they may represent to producers the real payoff for the demands of certification, they are no less subject to wrenches that local conditions can throw into the system.

\section{Running on the premio fumes}

As mentioned in the commodity chain discussion, a keystone of fair trade is the social premium offered in addition to the per-pound coffee price and intended for use in community development projects. When producers 
discuss the premio, it is often referred to as one of the more positive aspects of fair trade, allowing producers in Bella Vista, for example, to repair barriers in the coffee plots and machinery in the beneficio. The function of the premio was described as follows:

Yes, each one. Each one. By the quintal. Don Ramón turned in 10 quintales, [he received a premio for] an additional 10. I turned in 5 quintales, an additional 5 , like that. According to each one. Here there is a space where they from the assembly say, "Complying with the standards of the FLO premio." It is important to remember that each one of the organizations has an accountant, preferably with a bank account for use and management of the FLO premio. We ourselves make the decisions in a general assembly where there is a budget for the premio. Whatever costs according to the budget that have been approved by the general assembly must be documented the same here with the required receipts, whatever cost made by the organization, where the organization funds were used, so that transparency is one of principals that you have to demand. So. There you go. That is how we manage the FLO premio.

However, in recent years Grupo Organico has opted to divert the premio from a social development fund, as it had been used in the past, to a supplement to the FLO price.

They [members] don't notice the FLO premio. The quintal is worth to you, for example, 900 quetzales. But after that, they send you a little more money. But this money that they send, our buyer, is already meant for the schools or whatever other thing. And to take care of it, you will pay. But we here are accustomed to paying these things ourselves. So we hold onto it, only that we write it as he tells us to. And that way we are content. It turns out as we plan. Written and stamped and signed by all the cooperative members, because whatever the project we pay for it between us. -Cristóbal (interview, February 2, 2010)

The official statement from the Grupo Organico alludes to what other cooperative members described as the reason for diverting FLO premio funds. With the conventional coffee price approaching the fair trade price, Grupo 
Organico members are struggling to ensure that certified producers are financially compensated for their hard work. To maintain membership, given the stability (or stagnation) of the FLO price, Grupo Organico members see the addition of the FLO premio to the per-pound price to producers as the only means of maintaining a competitive edge over the conventional price. As a result, this primary advantage to Fair Trade participation is no longer benefitting the certified members of Grupo Organico.

\section{The problem of too much embeddedness}

For Grupo Organico members who are patiently waiting for Fair Trade to regain its economic advantage, the social benefits present one of the few carrots to continued participation. For Grupo Convencional members, donations of coffee plants and fertilizer to Grupo Organico members only appears as a punishment for a decision they feel they have made out of economic hardship. Unable to keep up with the rigorous labor demands of certification, ill-equipped to wait for delayed payments, terrified of the production lag associated with renovation, Grupo Convencional members felt that the Fair Trade system was to their economic disadvantage. Worsening the situation, Toro Verde offers donations and credit only to producers who remain in Grupo Organico. Though their need for materials such as seedlings and coffee pest traps is no less than their certified neighbors, Grupo Convencional members no longer have access to the resources they see distributed throughout the community. Compounding the situation is the presence of Bella Vista community members in the staff of Toro Verde, 
rendering these tensions more personal than if conducted by an unaffiliated development agency.

Then came along Toro Verde, giving out coffee plants at every house. But to me, they gave nothing. Then came a group of 50 [Grupo Organico] members, they came with coffee to give out, they pass by each house saying, 'This house is organic, we leave them coffee.' It's free coffee. They gave out traps [for broca coffee pest]. They pass by the house saying, 'This house is organic, we leave them coffee. This house is conventional, we leave them nothing. The next house is organic, give to them.' So, my question is, how is it that an institution established to help the poor farming people, why do they do these things? Looking at the face of a person saying, this person yes, this person doesn't get anything, this person yes... Now, people have needs. There's no money. You go to borrow money in the office. There is none. We are at 0 . But the president had a meeting with the Grupo Convencional and told us, 'Señores, those of us who are organic, we have a financier. Toro Verde. You guys in Grupo Convencional don't have anyone to finance you. You are at 0 . You have to see what you can do. You can cut some of your coffee and sell it to eat. We in Grupo Organico have someone giving to us. And we ask them for what we need.' So it makes you think, could it be acceptable that an institution treats a community like this? So I told the board, 'It is not me who is a problem. You have to look for the root, where it comes from, that put itself in the community, and see things clearly...' but this is our struggle. This is one of the biggest problems to happen to our community. It's not me. It's necessity that made me return to working like before, like the priest [preceding Reinaldo] taught us. If we see that this institution is not helping us, that it's dividing us, it can leave. But that's where we are now. That's why we have 2 groups. Our work is different. Morally we are united. We love each other like brothers. Only in work are things like this. But it's not our fault. It's the fault of the institution that didn't know how to put itself in a condition to keep the community together. Because unity depends on them. You're conventional, we'll help you, equal parts. That's how things continue going well. But the institution only wants to work in organic. Nothing conventional. That's how it is. Ovidio (interview, February 21, 2010) 


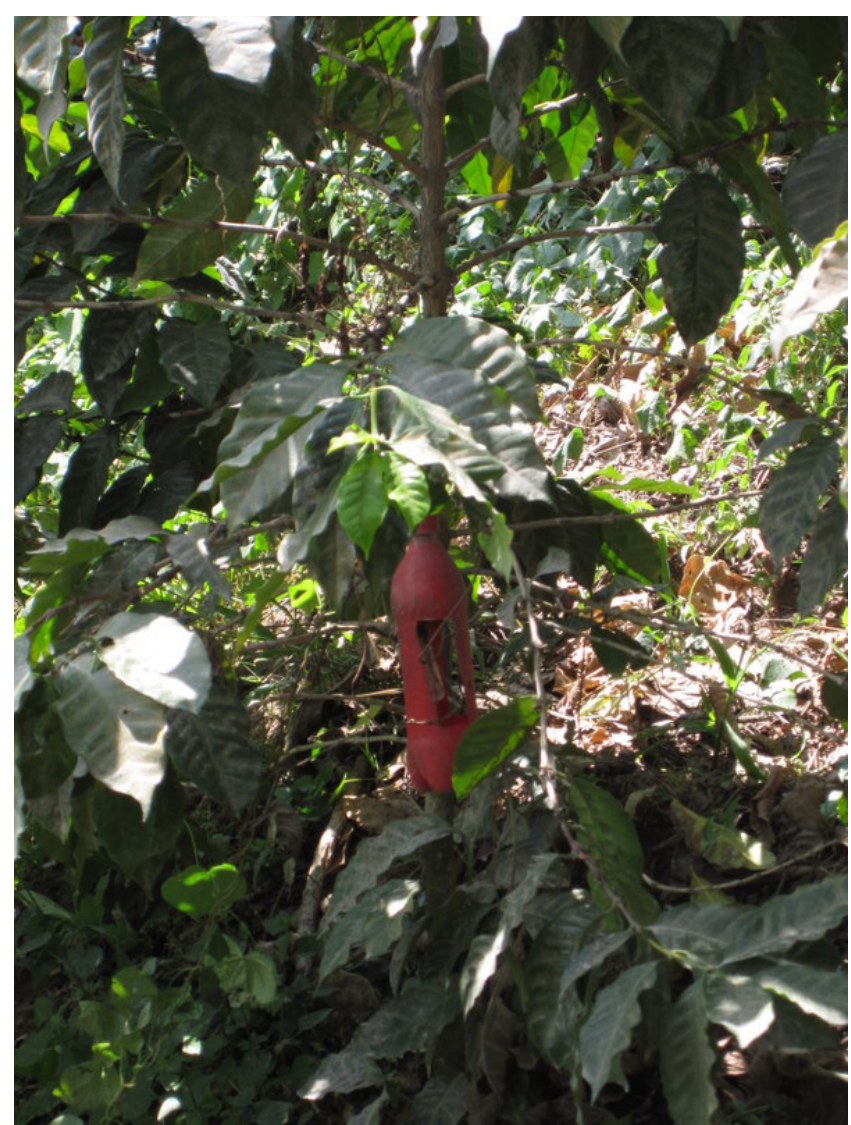

Figure 6.7 Broca trap: constructed using donations of red paint and rubbing alcohol from Toro Verde

In Alta Gracia, the embeddedness that had served their buyer so well in designing development projects eventually became a hindrance to effective work within the community. Upon establishing their trade relationship, Roundtable Roasters began frequent contact with the original president of the coffee commercialization project. He traveled to their offices in the US, he lectured the guests they chaperoned during their "delegations" to the community, he wrote them often about the state of affairs in the cooperative, and he became what many at Roundtable Roasters considered a close, personal friend. The residents of Alta Gracia continued to elect him as president of the coffee project as long as they were pleased with his administration. After seven years of successful re-election, the original 
president had become the only president of the coffee project. Only he knew how to conduct the duties associated with maintaining the coffee project, including both the coffee for export and coffee roasted on-site for sale in the local market. Eventually, relief at his responsibility for the project turned into resentment for a lack of transparency. Though residents had long been contentment to defer all questions and decisions to the coffee project president, this dynamic was turned on its head when suspicions arose regarding management of funds, accusations of embezzling were made, and eventually the president was oustered.

The result was an uncomfortable conflict of interest for Roundtable Roasters, wherein both the former president, pleading innocence of all charges, as well as the Alta Gracia cooperative both implored Roundtable Roasters to continue their trade relationship. While the former president was accused of using his ease of communication with Roundtable Roasters to his personal advantage, the purchaser had supplied the funds and resources that he was accused of misusing. To discontinue the relationship with the former president, now ejected from the cooperative, would be to turn their backs on a dear friend with whom they had worked closely for years. To discontinue the relationship with the cooperative would destroy Alta Gracia's confidence in their buyer. In the end, Roundtable Roasters purchased coffee from neither party, though they continue to offer social development support to the Alta Gracia cooperative. 
Further diminishing the social benefits to the community, Alta Gracia residents have also grown suspicious of Catholic Relief Services due to their association of this organization with the former president of the coffee project. Naturally, the CRS representative worked closely with the president of the coffee project, discussing the economic future of the community and how best to employ donated resources. As residents came to suspect mismanagement of funds from Roundtable Roasters, they also began to scrutinize the resources from CRS. As a result, they have inferred upon CRS the same crimes as the former coffee project president, accusing the CRS representative of favoritism, sabotage, and embezzling. In the end, many residents have rejected services and materials offered by CRS, declining the trainings offered and complaining that the donated plants they received were inferior and therefore a waste of labor and financial investment.

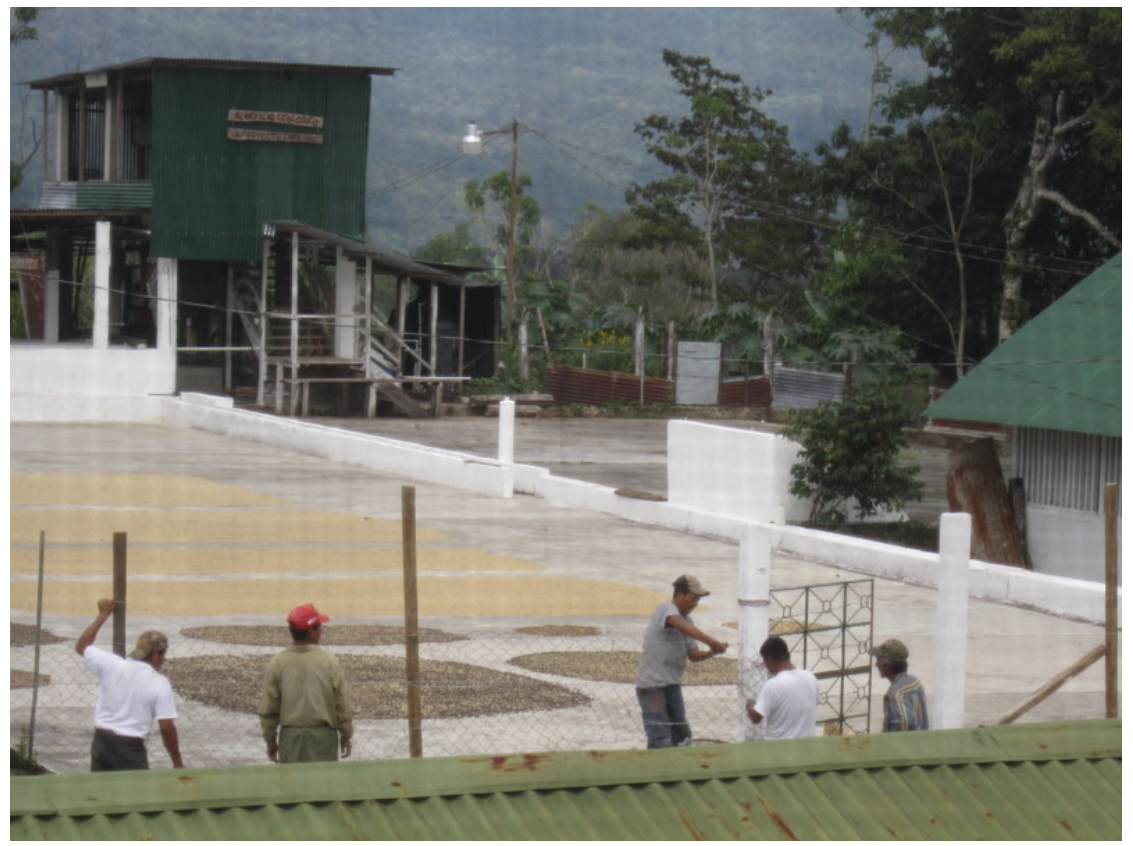

Figure 6.8 Fencing off the beneficio: newly elected administration of Alta Gracia erects a barbed-wire fence around the CRS-funded, recently repaired beneficio. The official story claims this as an effort to keep out stray dogs. Many residents, however, understand this as a euphemism for barring ejected coop members from the facilities. 
The problem of too much support

Earlier discussion of development projects gone awry mentioned the common problem of being inundated with assistance. Residents expressed concern that their attentions were being divided between too many interests, and subsequently all of the projects suffered from a lack of attention and investment. For this reason, producers suggested focusing development efforts on strengthening existing projects, particularly coffee production. Hearing this request, fair trade partners have assisted producer cooperatives in locating donations of inputs such as coffee plants and fertilizer, both intended to increase production volumes with robust new plants.

Contrary to expectations, reactions to donated plants have not been unanimously positive. One reason outlined in the previous section is related to community politics, where the donating agency is viewed by some as politically aligned with a political faction. However, another significant reason recipients have complained rather than embraced these donations is the overwhelming costs associated with donated materials. Specifically, coffee seedlings require a significant investment of labor to plant, especially using organic certified methods. When coffee growers in Alta Gracia called for donations of seedlings and their requests were obliged, they received an abundance of plants from Catholic Relief Services and PRIDE. To employ these plants in production, recipients were responsible for the associated labor of digging holes, transporting seedlings, transplanting and filling holes with suitable soil, and applying fertilizer. Several residents complained that the plants were too many to be properly cared for, both in the fields and in their 
nursery facilities, and that they would have preferred fewer, better cared-for plants to the spate of seedlings in their care.

Beyond the contents of individual projects, some residents questioned the long-term effects of so many donations on the independence and morale of the community. In La Esperanza, where residents have just recently voted to privatize land holdings and charge individual households with responsibility for their own coffee plots, this subject is of particular concern to community leaders. As one resident of La Esperanza cautioned:

...because we are not accustomed to, how do you say, investing. We are always accustomed to receiving money. We are not used to investing. So, I think that if the people don't save to invest ...they are not going to be able to invest. So if they don't invest, neither will they be able to produce. Therefore, this is the fear that I have. I hope that it will only be my imagination and will not become real, because if it were real, then we are going to be screwed. (vamos a fracasar) -Timoteo (interview, December 2, 2009)

The fair trade approach to development, then, can be seen in some

ways as perhaps too successful, providing producers with more resources than they can manage, and more unconditional support than is in the best interests of the long-term independence of the cooperatives it assists.

\section{CALCULATING THE VALUE OF FAIR TRADE}

Despite these relatively few complaints, social benefits remain the most appreciated of the impacts of the fair trade system. Producers value the direct investment in the productive capacity of the cooperative as well as the assistance in connecting to a broader network of supporting institutions. As a development scheme, fair trade systems can effectively deliver the resources and services that are sought by coffee growing communities. 
However, the importance of social benefits in balancing out the disappointment of economic impacts explains in many ways the brevity of La Esperanza's participation in the fair trade system. In a community such as La Esperanza, where connections are already in place to supply such development support, the social benefits of fair trade seem less unique and so go unappreciated. La Esperanza received assistance in many of the same areas as the other two cooperatives prior to their incorporation into the Toro Verde network. Already present were the schools, roads, trainings, Agricultural Committee, nursery, and composting facilities that Bella Vista and Alta Gracia have lauded as some of the main advantages of the fair trade system. Comparing the three communities, it appears that the versions of these projects that enjoyed more enduring success were fair trade-supported endeavors, suggesting perhaps La Esperanza's vivero or abonera might not have met such an early demise had they been accompanied by more longterm support such as the projects in Bella Vista. Similarly, the fate of the Agricultural Committee in La Esperanza might be more secure if reinforced by the system of promotores intrinsic to the fair trade system. Regardless, leaders in La Esperanza have independently sought out this support from international organizations, rendering the social benefits of fair trade redundant. Rather than introduce new services to the cooperative, their brief fair trade partners offered existing services at a greater cost - burdensome certification requirements and limited options for marketing their coffee. For a community already plagued by perhaps too much development assistance, the 
benefits of the fair trade system simply did not outweigh the drawbacks of regimented production and trade.

Furthermore, both recipients and donors have suggested a threshold of beneficial development assistance, beyond which the positive effects of aid are diminished, either by exceeding the capacity of recipients to effectively incorporate such resources into their production or by diminishing its value by being taken for granted. As a result, questions have been raised regarding the wisdom of attaching what can be viewed as charity to an exchange relationship.

Critics of fair trade argue that by subsidizing coffee prices, fair trade purchasers are ultimately doing coffee growers a grave disservice. Rather than instruct growers of the retail value of their coffee in the open export market, fair trade provides a flat rate for coffee, independent of quality, which obscures the crucial supply-and-demand relationship that should inform their decision-making. These critics, primarily economists, argue that if coffee growers were to better understand how coffee is valued they would make efforts to imbue their coffee product with more value-commanding characteristics. If they were equipped with the knowledge to translate demand for coffee quality into supply-affecting practices, they could create a better product that would command a higher price in the international market, thereby generating for themselves higher profits. If producers were able to affect the price they received for their coffee, they could earn greater profits to 
invest in production and community development, independent of a development organization.

So goes the criticism of fair trade frequently lobbed by economists. In this neoliberal solution to the poverty and development needs of coffee growers, greater information in the hands of producers will result in improved production practices, higher quality coffee, and more competitive prices offered by coffee purchasers. In this view, fair trade is counter-productive because it prevents producers from making the quality-price connection necessary to address consumer demand with a more valuable coffee supply.

In a related but opposing vein, the fair trade system has also been scrutinized for efficacy in addressing the system of "unequal exchange" it originally sought to repair. As coffee roasters have suggested, production of an export crop such as coffee can be viewed as "a dead-end street" and a "perpetual cycle," wherein profits are so consistently low as to necessitate loans to cover the costs of production for the following harvest that will again command low profits and necessitate further loans. Though coffee producers are the most economically vulnerable links in the commodity chain for coffee, though their labor is the most physically demanding, and though their confinement to production of raw materials has them bearing the brunt of risk in commodity exchange, their role is so undervalued that they receive the smallest portion of the retail price for their good. To correct this system of unequal production, fair trade has sought to revalue the labor of coffee cultivation by revealing the social context of production. This may result in 
higher prices for growers, but it does not necessarily effect the distribution of value along the commodity chain.

To retain more of the final retail price for coffee, producers would need to assume more of the value-added stages of production, including ascription of quality onto the coffee product. To accomplish this, coffee growers would first need to be knowledgeable of the various definitions of quality in the international market. This requires familiarity with the traits that consumers desire in a coffee product, qualities for which they are willing to pay a higher price. Since fair trade seeks to establish greater communication between producers and consumers, then coffee growers in a fair trade system should have greater awareness of the qualities that consumers value in a coffee product. To capture more value for their product, producers would need both awareness of these qualities that already exist in their own product, as well as means of enhancing these qualities through cultivation practices.

The next and final chapter brings together these two areas of criticism of fair trade, examining its potential to assist producers in turning coffee quality into coffee profits. To evaluate both economists claims that greater knowledge breeds higher prices and fair trade hopes that shorter commodity chains beget more "equal" exchange, the next chapter compares the responses of coffee growers in each market system - fair trade, Fair Trade, and conventional - to evaluate the relationship between the number of links in a given commodity chain and the market knowledge of producers. 
The following chapter explores producers' knowledge of the international coffee market, as well as the myriad definitions of quality held by both producers and purchasers, considering the association between greater market knowledge and the directness of a given market system. An examination of survey results will demonstrate how conceptualization of coffee quality is a reflection of one's role in the commodity chain, focused either on the activities of production or marketing, but seldom both. After evaluating the differential knowledge held both within and between communities, the chapter concludes by considering the potential for coffee growers to affect their prices. For even the most informed coffee growers, significant barriers to market entry likely preclude producer cooperatives from capturing any significantly greater value for their product. Though direct market participation, meaning direct export to retail purchasers, is a commonly-held goal among coffee producers in these communities, certain insurmountable logistical obstacles bar their independent participation in the international market. 


\section{Chapter VII: The Quality Quagmire}

The criteria are pretty much just specific to the contract. Sometimes purchasers will work in premiums for points over 85, you know, five cents a pound over 85 , or if you score a 90 l'll pay you 50 cents extra. You know, little incentives for growers to pay attention to that stuff. Which is a struggle because, unless Alta Gracia was sending us disgusting horrible coffee, we're gonna buy their coffee. If it's export grade quality that's over 80 or above, we're gonna buy it. And, and we're gonna put pressure on the price to bring it up to a decent level that they're happy with, regardless of what they do. We're not attaching it to quality criteria. I can understand that quality approach, saying, you know, "If it's over 90 we'll pay you more for it," or something like that, but I think that conversation has to start after we get back to adjusting it for inflation. And then, OK, sure, you wanna pay somebody $\$ 2.20$ or $\$ 2.25$ for it? Great. But to say, to acknowledge that $\$ 1.90$ is actually less than what the fair trade price was and, "I'll dangle this little opportunity for you to get up to $\$ 1.95$," to a struggling farmer feels a little horrible. You know, that's a little unsavory. It's undignified. -Darrell (interview, September 10, 2009)

From the very first interviews with fair trade coffee roasters, it quickly became apparent that, in a fair trade system, coffee quality and price do not operate in accordance with the laws of supply and demand. As the quote above demonstrates, many fair trade purchasers prioritize the needs of coffee growers over quality ratings. This may be due in part to their market limitations, but, whether unable or unwilling to participate in the high-dollar competitive quality market, some fair trade roasters peg their prices to producer demand rather than consumer demand.

Further complicating what was envisioned as the focal element of this study, the first surveys with coffee producers revealed their knowledge of coffee quality and foreign markets to be even less informed than anticipated. The original conception of research design was to ask producers a series of questions regarding certification opportunities, premium values, sources for 
market information, and coffee quality indicators in order to create a market knowledge "score" for cross-community comparison. Unfortunately, questions regarding organic and fair trade premiums were discarded almost immediately, as the majority of producers outside the ring of administration had, at best, heard the terms comercio justo (fair trade) or premio but had no clue of the implications, instead referring all such questions back to community leaders. Few producers had any idea where their coffee traveled beyond the farm gate. Almost none, save the growers of Alta Gracia, could identify the country in which their coffee was sold. Questions regarding the name of their purchaser and the final retail price of their coffee fared worse. Most disturbingly, their total inability to discuss coffee quality appeared to have a demoralizing affect on survey participants.

While the survey was intended to elicit a freelist of quality descriptors for "good" and "bad" coffee, it instead drew the frustration of participants who seemed not only unprepared to provide a single response, let alone a list of adjectives, but also now doubtful of their ability to complete the remainder of the survey. As a result, the concept of the market knowledge score was abandoned and the survey pared down to the most essential and informative items. The challenging questions of coffee quality and market knowledge were sandwiched between comparison questions of personal preference and reaffirming questions regarding personal practices so that respondents felt more reassured to proceed in the survey. 
Though not productive in the same way it was intended, the survey results as well as the process were illustrative of the varying dimensions of coffee quality and the exasperation of coffee growers at their exclusion from the retail end of production.

\section{DIMENSIONS OF COFFEE QUALITY}

\section{The production realm}

To evaluate survey responses, all the quality descriptors resulting from the freelisting activity were extracted, sorted, and then assigned to one of nine categories which seemed to naturally arise from responses. As it turns out, these nine categories correspond with successive stages of production, demonstrating the opportunity to enhance or degrade coffee quality along each step of the process from choosing strong seedlings to tasting a brewed cup of coffee. 
Figure 7.1 Dimensions of coffee quality

\begin{tabular}{|c|c|c|}
\hline Category & Defined as... & $\begin{array}{l}\text { Includes responses such } \\
\text { as... }\end{array}$ \\
\hline Sabor-Flavor & Common flavor descriptors & $\begin{array}{l}\text { buen/mal sabor, agradable, } \\
\text { ácido }\end{array}$ \\
\hline $\begin{array}{l}\text { Clasificación - } \\
\text { Classification }\end{array}$ & $\begin{array}{l}\text { Traits identified when } \\
\text { escogiendo (choosing) on the } \\
\text { coffee patio }\end{array}$ & $\begin{array}{l}\text { azul, tamaño, peso, verde, } \\
\text { primero, segundo, manchado }\end{array}$ \\
\hline Selección - Picking & $\begin{array}{l}\text { Traits identified in the parcela } \\
\text { that guide coffee picking }\end{array}$ & rojo, maduro, ballo, podrido \\
\hline Aroma - Aroma & Common aroma descriptors & $\begin{array}{l}\text { buen/mal olor, huele por } \\
\text { cascadita }\end{array}$ \\
\hline Mata - Plant & $\begin{array}{l}\text { Traits identified in the plant } \\
\text { itself }\end{array}$ & por variedad, semilla, injertos \\
\hline Beneficiar - Processing & $\begin{array}{l}\text { Traits resulting from activities } \\
\text { in the beneficio }\end{array}$ & $\begin{array}{l}\text { bien trabajado, humedad, } \\
\text { seca, fermentación, no bien } \\
\text { lavado }\end{array}$ \\
\hline Catación - Tasting & $\begin{array}{l}\text { Uncommon flavor descriptors } \\
\text { particular to the language of } \\
\text { coffee cupping }\end{array}$ & $\begin{array}{l}\text { por los expertos, cuerpo, } \\
\text { textura, herbal, floral, } 80 \\
\text { abajo, con cuchara }\end{array}$ \\
\hline Región - Region & $\begin{array}{l}\text { Traits associated with the } \\
\text { location }\end{array}$ & $\begin{array}{l}\text { terrenos bajos, clima, altura, } \\
\text { prime, duro, mas frío }\end{array}$ \\
\hline Quimico - Chemical & $\begin{array}{l}\text { Traits associated with chemical } \\
\text { use }\end{array}$ & $\begin{array}{l}\text { organico, convencional, } \\
\text { sano, limpio }\end{array}$ \\
\hline
\end{tabular}

The characteristics identified by coffee producers, to be discussed in greater detail below, differ significantly from those used by their retailers in the US. In fact, the terms illustrate two different worlds in the coffee commodity chain - one in which attention is focused on details of the production process, the other focused on certified categories of production as well as the standardized language of evaluation. While some overlap exists between realms - both producers and retailers understand growing region and absence of chemical use as indicators of coffee quality - the remainder of categories identified by producers are exclusive to their own discussion of quality. Conversely, the majority of terms used by coffee retailers are either unknown to producers or unrecognized as traits that enhance the perceived quality of coffee. 
The consumption realm

Though among the least frequently cited indicators of coffee quality, tasting characteristics are among the quality descriptors commonly used by coffee retailers. These internationally recognized descriptors of quality differ dramatically from those provided by coffee growers. Coffee "cupping" in consuming countries is a standardized taste evaluation process of brewing under specific conditions, breaking the "crust" to inhale the aroma, slurping the coffee (aspiration) by the spoonful, and assigning taste and aroma attributes based on a flavor wheel. This process bears much in common with wine tasting, where imaginations run wild with aroma descriptors such as "carmelly" and "resinous" and specific notes identified can range from "balsamic rice" to "tea rose" to "cedar" and beyond. 
Figure 7.2 Coffee Flavours Tasting Wheel

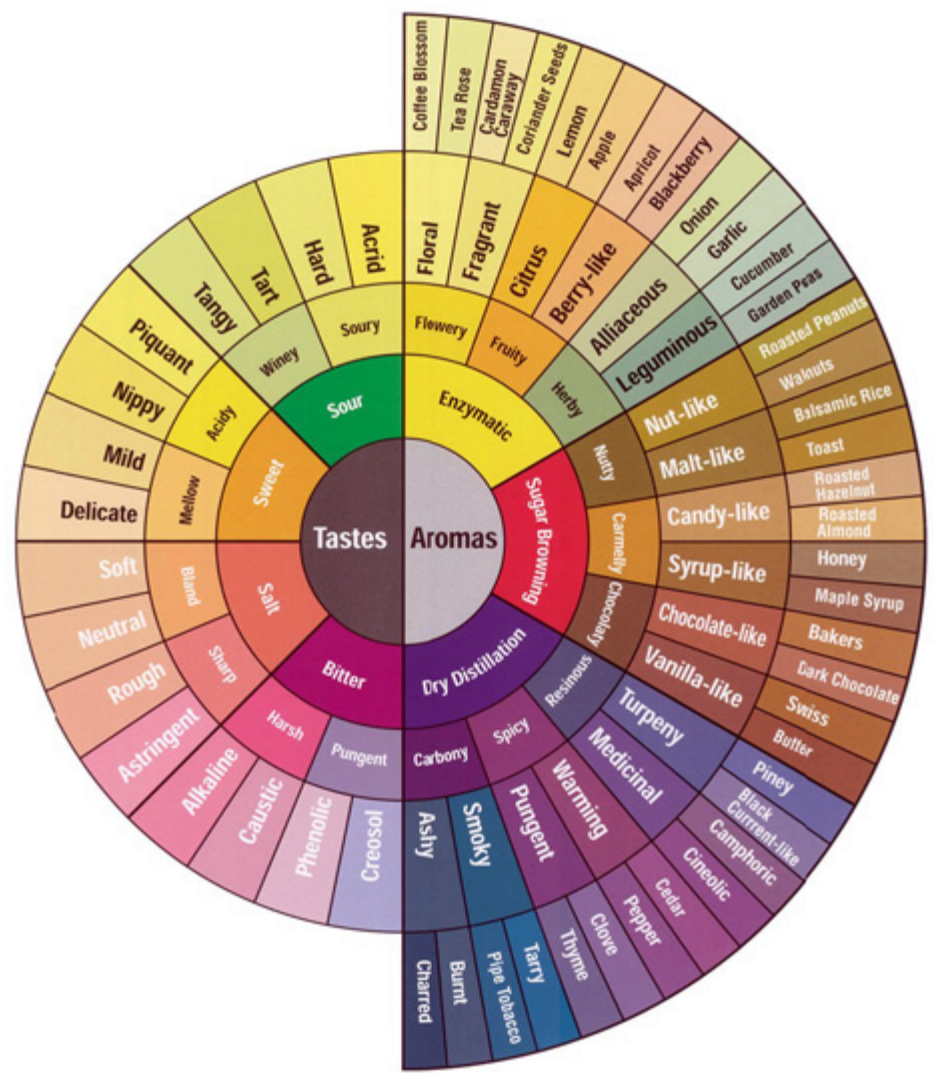

(Quaffee n.d.)

For example, one profile offered by a US retailer reads, “... gently roasted, this coffee slowly develops the amazing flavours expected form a high grown Guatemalan coffee. Fragrant floral notes touch on a fruity sweetness from the first sip to the last. Rich body and crisp acidity are finished with a short, sweet aftertaste." (Ethiopian Coffee Network N.d.) In a post on Clive Coffee Blog posted on July 26, 2010, another retailer describes their offering from this region as, "a well-balanced, thick bodied coffee, with a sparkling acidity complimented by hints of chocolate, dried fruit and delicate spices.

In addition such flavor and aroma descriptions, certain details about the context of production are usually included in the product description. For 
example, beyond "bright and floral with a nutty finish," Roundtable Roasters' offering of Alta Gracia beans is described as "light roasted fair trade, organic, shade grown coffee from the Alta Gracia grower coop in Colomba, Guatemala". These indicators of the location and social conditions of the growing site are commonly used by fair trade retailers to enhance the quality of coffee and thereby imbue the final product with greater value. Some retailers take the description one step further, providing on their websites brief biographies on their partner communities.

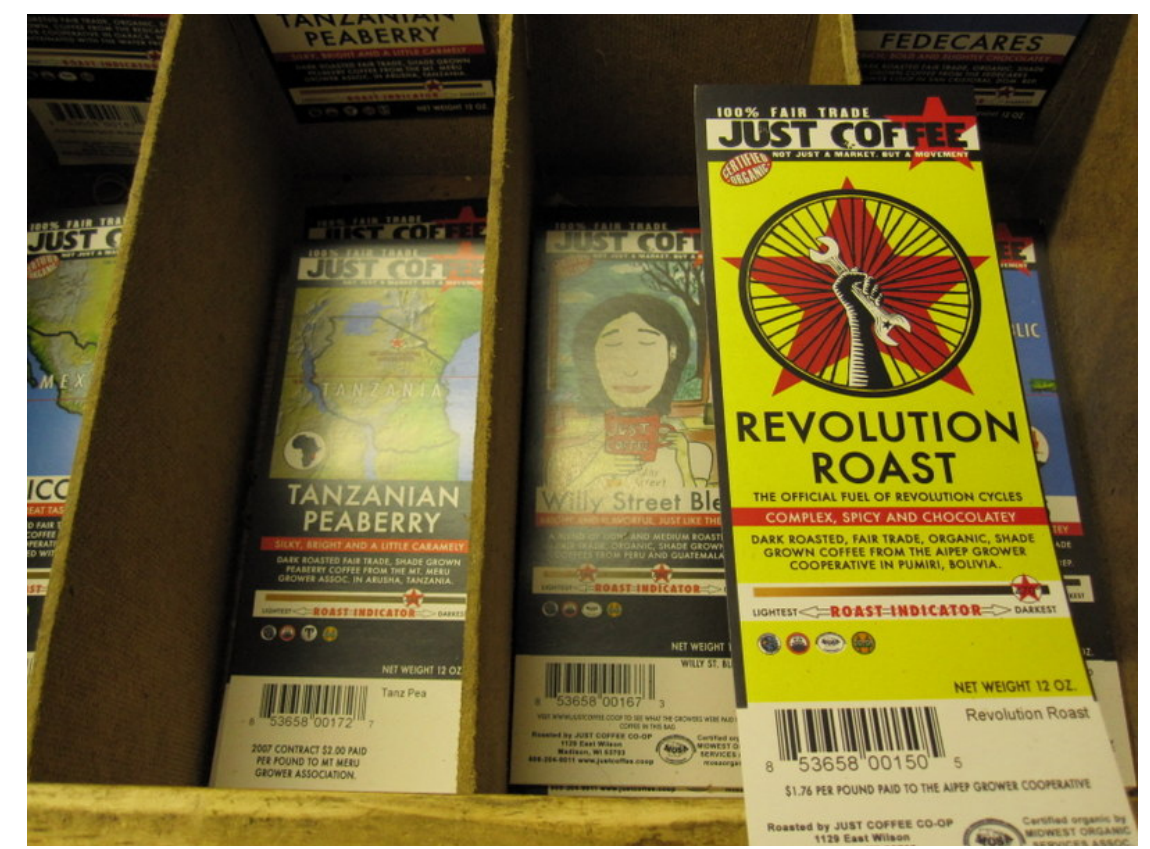

Figure 7.3 Revolution Roast: among the labels used by Just Coffee, a Fairtrade Federation member coffee roaster

To be sure, the reintroduction of consumers to the social context of production is a basis of the fair trade system. For this reason, retailers provide such product information as the name and size of the grower community, as well as the environmental and social responsibility of their production practices. Other descriptors, such as altitude and growing region, confer 
quality via status as a rare find, thereby increasing the retail value of a product. As Darrell (interview, September 10, 2009) of Roundtable Roasters explains,

If you have something that you can say, "This is a phenomenal Guatemalan coffee", people are gonna get excited about that. You just put a real medium roast on it and let it shine all on its own. And there are coffee shop owners that are looking for that. A lot of times you just hear from our customers, they wanna know what's new, and there's always something new. But if you can say this thing is just knocking people's socks off because it was handled in this certain way by this small grower group of families, people get excited about it.

Further insight into the differences in fair trade systems can be gleaned from a comparison of Fair Trade promotional materials with those of Roundtable Roasters. To describe their award-winning Guatemalan Antigua coffee from the Santa Barbara finca, Macy's Coffee states, "The central highlands of Guatemala produce some of the world's best and most distinctive coffee. These beans are grown at elevations of $4,500^{\prime}$ or higher. The coffee has a tangy flavor, medium-to-full bodied; a very rich cup of coffee." Further down the list of offerings, another Guatemalan coffee, billed as the singleorigin Organic Guatemalan offering from the Loma Linda finca, is merely described as "The same incredible flavor as our regular Guatemalan beans, but certified organic." (Macy's Coffeehouse \& Bakery N.d.) In contrast with information provided by Roundtable Roasters, Cooperative Coffees, Equal Exchange, and other non-FLO certified fair trade organizations who stress the importance of social context of production, here Bella Vista coffee is not promoted by any distinguishing features of the community, save those that 
indicate in a standardized language of altitude, region, and unique flavor characteristics.

Though producers recognize flavor, region, altitude, and certification as terms to describe coffee quality, they are unaware of how these terms function. Growers can list the regions which produce the "best" coffee, though their understanding of how this is defined is limited to the price that the coffee commands in the market rather than the way these terms are manipulated or these qualities enhanced to create a higher profit margin. For example, producers in all three communities understand that the "best" coffee in Guatemala is produced in the department of Huehuetenango and the areas surrounding Antigua. Precisely how this coffee is defined as "best", however, is limited to the superior prices fetched by these coffees in national market and altitude distinctions such as "prime" and "semiduro", terms used in the Guatemalan coffee grading system, which are common in the domestic market but rarely appear in retailers' promotions. In fact, the majority of respondents in each community were unable to name the altitude or grade zone of their own coffee, either in meters above sea level or in terms of the prime to estrictamente duro scale. Alta Gracia residents fared best, with $38 \%$ correctly identifying their altitudinal zone, compared with $25 \%$ of respondents in Bella Vista and $17 \%$ of La Esperanza respondents. There is a disconnect, then, between producer and retailer conceptualizations of coffee quality, which continues to prevent producers from using the language of coffee quality to a negotiating or producing advantage. 
While producers are inherently responsible for adding many of the qualities that enhance the value of coffee, they do not always recognize the value-adding opportunities presented in their own activities. Much of the symbolic qualities of coffee are based in production practices, such as fair labor conditions and organic cultivation. Though material quality associated with flavor, size, and aroma is in part tied to roasting activities, it is also largely based in good processing on the farm and the unique soil and climate characteristics of the site of production. Survey data reveal producers' appreciation for careful cultivation and processing, enhanced by fair trade partners' feedback and reinforcement through ongoing training. Lacking in their conception of coffee quality, however, is an understanding retail-end value-adding activities and vocabulary.

\section{QUALITY CONCEPTS AND COMMUNITY IDENTITY}

Not only do concepts of quality differ between producers and retailers, but they also differ between producer communities. Within each community, one prevailing theme of coffee quality emerges, which reveals the confidence and aspirations that cooperative members hold for enhancing the value of their product. 
Figure 7.4 Quality knowledge survey: ¿Como se describe, o como describe...

\begin{tabular}{|c|c|c|c|c|c|c|c|c|}
\hline & \multicolumn{4}{|c|}{... un café de buena calidad? } & \multicolumn{4}{|c|}{... un café de menos calidad? } \\
\hline & total & $\begin{array}{l}\mathrm{LL} \\
(\mathrm{n}=25)\end{array}$ & $\begin{array}{l}\text { SA } \\
(n=24)\end{array}$ & $\begin{array}{l}\text { NA } \\
(n=24)\end{array}$ & total & $\begin{array}{l}\mathrm{LL} \\
(\mathrm{n}=16)\end{array}$ & $\begin{array}{l}\text { SA } \\
(n=22)\end{array}$ & $\begin{array}{l}\text { NA } \\
(n=19)\end{array}$ \\
\hline \multirow[t]{2}{*}{ Flavor } & \multirow[t]{2}{*}{18} & 7 & 6 & 5 & \multirow[t]{2}{*}{11} & & & \\
\hline & & & & & & 3 & 5 & 2 \\
\hline \multirow[t]{2}{*}{ Classification } & \multirow[t]{2}{*}{18} & 6 & 7 & 5 & \multirow[t]{2}{*}{15} & & & \\
\hline & & & & & & 6 & 4 & 5 \\
\hline \multirow[t]{2}{*}{ Picking } & \multirow[t]{2}{*}{14} & 0 & 12 & 2 & \multirow[t]{2}{*}{13} & & & \\
\hline & & & & & & 2 & 10 & 1 \\
\hline \multirow[t]{2}{*}{ Aroma } & \multirow[t]{2}{*}{7} & 3 & 2 & 3 & \multirow[t]{2}{*}{4} & & & \\
\hline & & & & & & 1 & 1 & 2 \\
\hline \multirow[t]{2}{*}{ Plant } & \multirow[t]{2}{*}{7} & 1 & 3 & 3 & \multirow[t]{2}{*}{2} & & & \\
\hline & & & & & & 1 & 0 & 1 \\
\hline \multirow[t]{2}{*}{ Beneficio } & \multirow[t]{2}{*}{17} & 3 & 12 & 2 & \multirow[t]{2}{*}{7} & & & \\
\hline & & & & & & 0 & 5 & 2 \\
\hline \multirow[t]{2}{*}{ Tasting } & \multirow[t]{2}{*}{8} & 4 & 3 & 1 & \multirow[t]{2}{*}{2} & & & \\
\hline & & & & & & 1 & 1 & 0 \\
\hline \multirow[t]{2}{*}{ Region } & \multirow[t]{2}{*}{21} & 10 & 4 & 7 & \multirow[t]{2}{*}{10} & & & \\
\hline & & & & & & 3 & 4 & 3 \\
\hline \multirow[t]{2}{*}{ Quimico } & \multirow[t]{2}{*}{22} & 6 & 7 & 9 & \multirow[t]{2}{*}{20} & & & \\
\hline & & & & & & 6 & 6 & 8 \\
\hline Don't know & & 13 & 0 & 3 & & 22 & 2 & 8 \\
\hline
\end{tabular}

For Bella Vista producers, the value of their coffee is tied to the value of

their land. Producer region was overall one of the most commonly cited indicators of quality, but its precedence was most striking in Bella Vista, where responses such as "café de altura" produced in areas "mas frío" was the most frequently mentioned category. In Bella Vista, great pride is taken in their idyllic volcano-side location and the pristine nature of their forested surroundings. The community presents itself to potential visitors less as a coffee-producing community than a site for enjoying fresh air, beholding unadulterated nature, and possibly sighting the elusive national bird, the Resplendent Quetzal. Residents know that their coffee is sought after by coyotes, who are willing to pay more for the duro grade coffee that is associated with the high elevation. 
Just as revealing as the responses themselves is the non-response rate of respondents in Bella Vista. Members of both groups struggled to provide a response to the question, "Como se describe, o como describe un café de buena calidad?" ("How is it described, or how would you describe a good quality coffee?") Of 38 survey respondents, 13 (34\%) were unable to reply, compared to zero respondents in Alta Gracia and three in La Esperanza who declined to respond. When asked to describe a less-quality coffee, Bella Vista residents hesitated further, with $22(58 \%)$ non-responses, compared to two in Alta Gracia and eight in La Esperanza. Whether this is due to lack of training or less consequence for such knowledge is unknown. In the context of this study, the inability or unwillingness of Fair Trade certified producers to answer questions regarding coffee quality suggests an inferiority of the Fair Trade system in preparing producers to participate more independently in valueadding activities.

In Alta Gracia, hope lies in the capacity to overcome geographical constraints and upgrade their classification. In striking contrast with the other two communities, Alta Gracia residents most often mentioned careful picking practices and beneficio processing as most indicative of good quality coffee. Alta Gracia is technically located in a semiduro producing region, where most fincas produce coffee of inferior quality for the export market. However, residents claim that with painstaking control, they have elevated their coffee to duro status, much to their neighbors' amazement.

It's for the elevation above sea level. Higher coffee is better, bigger grains, better flavor, because in Coatepeque the coffee is called extra 
prime. It is a coffee of really poor quality. Café prime. This coffee is poor quality. The coffee there from the first fincas is a café semiduro. It is already better quality. We are a semiduro. But we do control for quality. We practice control very strictly. Only us, in Alta Gracia, produce a café duro. Here there is a big finca that produces thousands of quintales of coffee, but it is semiduro, while we have achieved a duro. We have arrived at duro. Higher, it is café estrictamente duro. That's why our coffee [not exported but bought from neighbors and sold in the tostaduría project] has a good flavor, because it is estrictamente duro. It is good quality coffee. The best coffees are from Antigua and Santiago Atitlán because they are 2000 [meters] above the sea. But it depends if they have control for quality. Because the ones here cannot achieve a duro. Only semiduro. So they are shocked - how do we achieve a duro? - Francisco (interview, March 11, 2010)

The message that attention to practices in the fields and the beneficio can improve their coffee quality resonates throughout the community. The converse also holds true, as picking practices and beneficio work were both cited as the most indicative of poor quality coffee.

That these categories were significantly more popular here than in either of the other two communities is also a reflection of the age of the cooperative. In Bella Vista and La Esperanza, where residents have been picking coffee for generations, picking and processing are taken for granted. In fact, 0 respondents in Bella Vista and only two in La Esperanza mentioned picking practices as related to coffee quality compared to $50 \%$ of respondents in Alta Gracia. Similarly, only three and two respondents in these respective communities mentioned beneficio practices as influential in coffee quality, compared again to $50 \%$ of Alta Gracia respondents. For Alta Gracia residents, the majority of whom are now first-generation caficultores, or coffee growers, all work in the coffee fields and beneficio is a new enterprise with great potential for improvement or ruin. This is not to say that Bella Vista and La 
Esperanza growers do not realize the importance of picking and processing for coffee quality, but that these influences may considered more of a given, not at the forefront of their discussion.

Realizing the market potential of their newly certified status, La Esperanza producers emphasize the organic properties of their coffee production. La Esperanza has long promoted itself as an organic and fair trade coffee cooperative, even before participating certification systems. The former community president, still serving as President of Projects, has significant experience travelling internationally, both to the US and Europe, where he noted the importance these consumers placed on organic production. As a result, this community listed organic status and chemical use as the most indicative of coffee quality.

Emphasis on chemical use in La Esperanza is also reflective of internal conflict stewing at the time of the survey. Having recently voted to individualize landholdings in the community, there is concern, particularly among cooperative leaders and collaborative NGOs, that not all residents will uphold their commitment to organic cultivation. With each household responsible for their own labor and input costs, there is sound reason to fear that some growers will begin to employ agrochemicals in their personal cultivation practices. Reckless chemical use could endanger the organic certification of the entire cooperative. Side-by-side cultivation of organic and conventional coffees is only possible in Bella Vista due to carefully orchestrated growing practices, judicious use of barriers to demarcate the conventional growers, 
and a continued prohibition on chemical pesticides and herbicides. Conventional cultivation by some in La Esperanza without a consensus of ground rules and collaboration among households could threaten the market opportunities for those who continue organic practices. Moreover, were some households to default from the cooperative, the total volume of production for sale as organic certified coffee would be diminished, thereby compromising the leveraging power of a community that strives to produce a full container of export-grade coffee. This preoccupation with the continued organic status of the cooperative likely explains La Esperanza residents' emphasis of chemical use as a primary indicator of coffee quality.

Despite the notable differences in prevailing responses by community, similarities lie in the areas that are largely absent from producers' discussion, particularly those used most by coffee retailers. Two of the areas least frequently suggested by respondents are those that pertain to formal evaluation and the spectrum of flavor and aroma description. Of the twelve respondents who suggested one or both of these dimensions as indicative of coffee quality, at least five have held positions within the cooperative which require formal training in coffee tasting. Their responses included specific evaluation terms such as "floral" and "80 abajo". The remainder of responses in these categories included vague references such as "por cuchara," referring to the spoon-tasting stage of flavor evaluation, and "solo un catador puede decir," ("only a taster could say") in deference to the formally trained evaluator. Responses of this type do not reflect any actual familiarity with evaluation 
quality indicators, but instead suggests the exclusive nature of the flavor and aroma realms of quality. The dearth of responses in these categories suggests producers have made some progress in understanding the language of coffee quality, though it is concentrated primarily in the hands of a few influential cooperative leaders.

\section{THE FUNCTION OF QUALITY}

The language of quality, with which growers are largely unfamiliar, is an essential element for coffee retailers to market and sell their product. Flavor descriptors are a key means of differentiating one coffee product from another in a competitive market. Although consumers are often unaware of the particular taste and aroma attributes of coffee, roasters take it upon themselves to educate consumers about the desirability of certain characteristics, thereby adding value to their own coffee product.

There are people who will say "Give me something from Guatemala, because I want something bright," but there aren't that many people who say that. What Matt's working on right now is sort of a workshop that he's gonna teach to café owners and operators, so that the people understand coffee better. And that's basically what he's doing is putting together his curriculum for that, taking notes and trying to figure out how to deliver his message to the people... He operates what's called Full Circle Café Services, and the idea of this business, which is part of Roundtable Roasters, is to service the equipment of cafes but to also capacitate them for preparing coffee properly or maintaining the equipment properly and to understand quality... -Darrell (interview, September 10, 2009)

To command a higher price for their coffee, to retain more of the final retail price attributed to the appealing flavor profiles of their product, producers would need to able to do the same, to describe their coffee using flavor and 
aroma terms that add value and command a higher price in the international market. Fair trade coffee purchasers recognize the importance of this process and may strive to educate growers in evaluation practice and vocabulary.

After the pre-financing contract is taken care of, there is a pre-shipment cupping report, which allows us to evaluate the quality of an entire coffee lot before it leaves port. We and our members work with farmers to train them to cup their coffee, which provides them with a better understanding of their particular coffee in order to better market their product and thus negotiate a suitable price for their coffee from other buyers. -Coop Coffees (Fairtrade Foundation N.d.a)

Because many quality attributes are borne of the unique soil and climate characteristics of the site of production, coffee growers are inherently responsible for the process that imbues coffee with such valuable traits. However, until they participate more in the process of evaluating and describing coffee in terms that appeal to consumers, they will not be able to capture this value for themselves, or demand a higher price for their product, without the assistance of roasters and retailers.

\section{THE IMMATERIALITY OF COFFEE QUALITY}

In general, the general guidelines are that, first off, that it score 80 or above in the SCAA's sort of taste criteria, which just shows that it was handled properly or in certain ways after it was harvested, that it was processed well, that all the defective beans have been removed. So 80 or above is criteria number one... and then the other side of quality is where fair trade becomes relevant. Is it a fair price? Which is a huge discussion about what is really a fair price. And then, what is happening in the relationship between the purchaser and the seller? Is it a long term relationship? Is the buyer committed to coming back next year? To working on issues of coffee inside the community or outside of coffee that are still inside the community? Like we were saying, pharmacy projects or school projects or whatever else. So that's the larger meaning of quality. What's the quality of the relationship? What's the quality of the economics for the farmer? Which should be a part of 
agriculture in all agriculture, but right now we don't have that, because money's driving everything. -Darrell (interview, September 10, 2009)

Both Bella Vista and Alta Gracia cooperatives have been reprimanded in the past for subpar coffee quality. In both cases, humidity affected the quality rating of the coffee, either due to poor practices or degraded storage facilities. Also in both cases, coffee was purchased and compensated with the contract price just the same, though payment was accompanied with admonishment and advice for improving quality for the following year. Additionally, Alta Gracia's cooperative received assistance through their fair trade connections to improve the storage facilities in their beneficio. While this forgiveness and support well represents the broader definition of quality held by many in the fair trade network, it also epitomizes the criticism lobbed by economists at the fair trade system - that it prevents producers from associating coffee quality with market price.

Theoretically, partners at the retail end of the coffee commodity chain are causing more harm than good by hindering their suppliers from learning to participate more independently in the market. Economists would instead prescribe a lesson in tough love, where producers would be penalized for inferior quality with deductions from the contract price. Hypothetically, then, coffee growers would have an incentive to improve the quality of their coffee, which would render them more competitive players in the international market, granting them a higher per-pound price for their coffee. However, a closer examination of the commodity chain for coffee reveals the immateriality of quality in securing for producers a greater share of the retail price for their 
coffee. Structural considerations, such as shipping and licensing costs and the difficulty of orchestrating quality upgrades, indefinitely bar producer cooperatives such as those featured in this study from participating in the most lucrative stages of production. Moreover, it will be shown that, even for producers who have effectively transformed coffee quality into higher prices, the objective of long-term direct trade relationships remains as an ultimate goal. This suggests that the opportunity to participate more competitively and independently in the international market is still insufficient to meet the greater needs of producers.

To growers of this productive capacity

For some growers, the monetary incentives to improve quality are significant. The Cup of Excellence competition is an annual contest which grew out of the International Coffee Organization's Gourmet Project. The competition, now held in eight Central and South American countries as well as Rwanda, allows bidders to compete in an auction for select lots of highgrade coffee. The auction is intended to showcase high quality coffees for interested buyers from around the world and to encourage investment in the production of gourmet coffees. Prices offered by the highest bidders range from $\$ 6.00$ to as much as $\$ 80$ per pound. In 2008 , the last year for which detailed information is available for public viewing (Cup of Excellence N.d.a), quality scores ranged from 86.95 to 93.58 , with top jury descriptions that read, "citric (16), crystal clean acidity (13), grapefruit acidity (9), structure with spine (13), orange (22), syrupy (9), smooth (18), layers in the mouth feel (9), 
caramel aftertaste (10), dark chocolate (5), sweet lemonade like (8), creamy (8), choc. long finish with tart fruit (13), chocolate aftertaste (5), concord grape (5), soft mellow (6), winey (3), jasmine (5), orange blossom (3), grape aroma (7)". (Cup of Excellence N.d.b)

While the Cup of Excellence presents precisely the type of market environment hailed by critics of fair trade, a rudimentary examination of prizewinning farms reveals a significant disparity in size and production volume compared to the cooperatives in this investigation. For the 2008 competition, the top ten prize-winning farms produce an annual harvest of almost 3000 quintales of coffee on an average of 207 hectares of land in cultivation of coffee, indicating an average production of 15.96 quintales of coffee per cultivated hectare. In contrast, for the communities in this study, which range in size from 325 to 174 hectares in coffee production, to independently fill a 400 quintal shipping container indicates a successful year. In Bella Vista, Grupo Organico members harvested an average of about 7.5 quintales of coffee per hectare. Alta Gracia producers produced even less, averaging under 5 quintales of coffee harvested per hectare. Such disparities in production volume indicate significant differences in earnings to reinvest in quality improvement efforts.

Moreover, 21 of the 25 prize winning farms for 2008 appear to be operated by a dueño, a single land-owning family, usually with generations of experience administering the farm (Cup of Excellence N.d.a). This indicates an important contrast in social organization and labor relations with the 
cooperatives of this study. Whereas single-owner farms operate under a centralized authority figure, responsible for calculating the investments and earnings of the farm, independently making decisions, and delegating responsibility to hired laborers, the cooperatives featured here have struggled to work collectively, with unified production goals, techniques, and objectives.

A lot of times it's like, "Oh, we gotta get the coffee in." You harvest it, you spend this long night of going through all these important steps, and maybe they don't pay attention to all of them. There's different people doing it through the course of the day or a week, and some people are gonna be more diligent at it than others. So, if it's 80 or above, that's fine. And then, over time, over a three- or five-year period, if you can say, "Look, get everybody to work on this one control point," you know, how long is it going to sit in the water, or how long is it from when it's picked to when it's depulped, or how long is it in any one of these steps. That can be one of those things that always keeps it above an 82. And then you do another thing that always keeps it above an 83 or whatever. -Darrell (interview, September 10, 2009)

High volume production generates more income to finance quality improvement, and changes in cultivation and production strategy can be more effectively administered under the authority of a single finca owner. Clearly, the majority of farms that enjoy success in the Cup of Excellence annual auction comprise an entirely different class of coffee farm, one in which these small-scale coffee cooperatives would struggle to compete.

To the role of producers in the coffee commodity chain

Looming over the debate of whether fair trade hinders producers from effective participation in a competitive market is a bigger question which asks, even if they are improving market knowledge - to what end? Learning about supply and demand and coffee quality is irrelevant to competition in the 
international market if producers are not able to employ this knowledge as a lucrative means to an end, and unfortunately, the nature of a raw material such as coffee precludes growers from participating in some of the more value-adding stages of production. Short of informing a better negotiated coffee price, market information in the hands of coffee growers may offer more disillusionment and vexation than opportunity to capture value.

As a primary commodity, the basic characteristics of coffee render producers incapable of performing the greatest value-adding stages of production. Coffee weighs less when transported as green beans in 100pound burlap sacks than as roasted coffee in the 16 ounces (or less) packages typically used by retailers. Moreover, the shelf life of roasted coffee is considerably shorter than that of green beans. Consequently, if producers were to attempt to capture the value added via quality descriptions on roasted, packaged coffee, the additional weight would add significantly to the cost of international shipping. Though the retail price in Guatemalan fair trade shops is around $30-40 \mathrm{Q}(\$ 3.85-\$ 5.12)$ per pound, local market opportunities are limited. Furthermore, the comparatively shorter shelf life of the roasted product would increase the risk of financial loss for unsold, stale coffee.

Additional logistical constraints prevent direct trade from being a viable option for cooperatives with such small production volumes as those included in this study. As mentioned earlier, fair trade grants the opportunity to participate in export markets to cooperatives with production volumes too small to independently cover the cost of entry. In a fair trade system, producer 
cooperatives unable to fill a single container combine their product with another group and share the shipping costs. Export license fees are spread across member cooperatives rather than shouldered by a single producer group, as are the costs of services rendered in the bodega. The transaction fees alone associated with direct trade prohibit the independent participation of such small producer groups as those featured in this study.

Despite all these obstacles to more independent market participation, direct trade is still the ultimate goal for producer cooperatives. Community leaders in La Esperanza requested from assistance from several NGOs in applying for an independent export license. Alta Gracia growers and NGO advisers considered terminating the relationship with Roundtable Roasters to exclusively sell their own roasted and packaged coffee in fair trade shops and airport kiosks in the local market. Such objectives in absence of cost-benefit evaluations or business plans can serve as indicators of just how uninformed many producers are yet of the logistics of direct trade and retail and the constraints associated with the production end of the coffee commodity chain.

To the ultimate goal of coffee growers

Interestingly, even among prize-winning gourmet coffee producing farms, direct trade with a foreign purchaser is the ultimate and elusive goal. Just as the cooperatives in this study strive for direct market access, the high visibility gourmet coffee farms of the Cup of Excellence competition hold out the same hope to alter the coffee commodity chain. Among the histories and 
microclimate descriptions provided in the biographies of the 2008 competitors are their objectives for future development:

I love coffee. My dream is to sale [sic] our coffee directly to a buyer. Have a direct relation and be proud of where my coffee is going [sic] sold. - Finca Chalabal (Cup of Excellence N.d.c)

Finca Florencia's goal is to provide our costumers [sic] the best coffee beans in the world. We are searching a coffee buying company that is looking for a long-term relationship. Our expectation is to work closely with our buyer, not to only sell the best coffee beans in the world, but to sell social and ecological responsibility. The revenue of our sales will be invested in a social project within the farm. -Finca Florencia (Cup of Excellence N.d.d)

When we received Cup of Excellence 2008 award, we thought that all the efforts, sacrifices and dedication for producing exemplary coffee was worth it. Now, we would like to know who buys our coffee lot. We would like to build a close relationship, learn from the buyer how this coffee will be sold to the final consumer, invite them to visit our farm and show them how the coffee was produced. And why not, maybe some day [sic] visit them and drink a fine cup of coffee. -Finca Las Rosas (Cup of Excellence N.d.e)

We believe that farms can only be sustainable if we are able to build long term relationship that allow us to responsibly plan our investments to improve life of employees and preserve our natural reserves. Coffee has given us many satisfactions. Some of them are to be able to share and transmit our knowledge to our family, to be known as producers of high quality coffee with social and environment responsibility. We have also made technical improvements to the farm, wet mill and build [sic] relationships with buyers. All of these have reflected results in the improvement of our employee's [sic] lives. -Finca La Soledad (Cup of Excellence N.d.f)

Our main goal is to find a niche market that allows us to receive better prices. This will help us stop depending on middlemen. -Finca Chichupac (Cup of Excellence N.d.g)

Winning awards is very special for our group. We used to sell to middlemen and it was very disappointed [sic] to our members and families when they did not pay prices already agreed or when the crisis affected our income. We want to continue investing and improving our mill, coffee plantations and provide our families with education and health. We want to be competitive growers with high quality that can 
satisfy better markets. It is not an easy task. Specially [sic] selling directly and maintaining quality. But we also know that the altitude and varieties are a perfect start. We grow Typica, Bourbon, Catuai, Caturra and Pache. Selecting our coffee lot, without you knowing it, was recognizing the ability of small coffee growers to produce high quality coffee. That was really the greatest recognition! We celebrated with all members of our group and we are very thankful to God and the organizers. We would like to meet our buyers and invite them to our community. Cup of Excellence has given us the opportunity to access markets where our quality is appreciated. Let us now show you a world where thankfulness, kindness and heart simplicity award those that give us an opportunity. -La Pacaya and La Cumbre Amalem (Cup of Excellence N.d.h)

Despite their success in the competitive market, the objectives of these farms echo the mission of fair trade - face-to-face contact with a purchaser to establish a long-term, direct trade relationship. Furthermore, the angle from which many of these cooperatives pitch their product reflects a familiarity with the fair trade movement. Though none of the prize-winning farms claim fair trade or organic status, they do highlight their efforts at "social and ecological responsibility". This suggests that either the mission of fair trade is in line with the goals of producers or that these producers are courting a particular type of buyer.

For many of these high-quality producers, the Cup of Excellence competition seems to present an opportunity for networking, a tool for increasing visibility and developing a "relationship coffee" system. Future research could investigate the possibility that producers use the auction much like the producers of Alta Gracia used their Fair Trade status - as a stepping stone to a greater ultimate goal and an introduction to a network of suitable purchasers. Further investigation of the expectations for and impacts of quality 
competitions such as the Cup of Excellence could reveal whether producers view the auction as a supplement to their current market system or a means to another goal.

\section{A MORE PROFOUND UNDERSTANDING OF QUALITY}

The exclusion of coffee producers from the most lucrative, value-adding tasks in coffee production recalls the original intent of the fair trade movement - to alter the system of unequal exchange. Fair trade was initially conceived as a means of revolutionizing trade, taking the gamble out of something so crucial as one's livelihood and making the terms of trade more "fair" for producers at the mercy of the international market. Painstaking efforts may be made to ensure coffee quality and to communicate this quality during price negotiations, but because of the nature of their role as producers of a raw commodity, coffee growers are exceedingly vulnerable to circumstances beyond their reach.

... But then there's an unexpected rain or a long period of drought at the wrong time of year, and that stuff's all out of your hands.... It would be nice if people on our end of it would understand how much of it is out of their control. And there are a lot of control points where you can influence quality, and you can be really diligent and control defects, but there's a lot of it that is out of your control, too. And you know, it's agriculture. It's the world. It's unpredictable and imperfect. -Darrell (interview, September 10, 2009)

For producers, whose entire livelihood is staked upon one annual sale, attention to quality and market opportunities are not sufficient to guarantee an income. All the meticulous efforts of proper grafting, planting, and fertilizing can be negated by unfavorable climatic conditions so subtle as a few days of 
strong wind or rain. Training in ideal picking, fermenting, sorting, and drying practices is inconsequential if, as often happens, natural disaster compromises the raw material of the coffee harvest. Critics of fair trade may emphasize the importance of learning to be competitive in the market, but they cannot deny the precariousness of coffee cultivation as a primary source of income.

Rather than occlude from producers the "triggers" to respond to fluctuations in supply and demand, fair trade offers a safe opportunity for producers to learn about coffee quality through trainings and feedback from purchasers. Contrary to the criticism of free market economists, coffee growers in a fair trade system are, in fact, developing skills in various aspects of quality improvement. Bella Vista growers demonstrate awareness of the symbolic value of their regional distinction, and several community members have received training in the process of cupping evaluations. New to coffee production, Alta Gracia residents recognize the importance proper picking and processing in enhancing the material value of coffee. On the forefront their minds in La Esperanza is preserving the value of their status as organic farmers. While some awareness of the value ascribed by these qualities can be attained through conventional sales, fair trade partners demonstrably work to increase producer awareness of opportunities to enhance coffee quality.

Unlike the competitors in the Cup of Excellence competition, at the same time as fair trade growers learn methods of control to enhance coffee quality, they are protected from the consequences of circumstances out of 
their control. In recognition of the fragility of raw material production, fair trade provides a safety net of a guaranteed minimum price, a long-term buyer, and a network of auxiliary support on stand-by in case of natural disaster. This demonstrates the broader conception of quality called for by members of the fair trade movement, encompassing not only the results of product evaluation but also the characteristics of the trade relationship and its repercussions in the context of production.

Because even the most well-informed, most thoroughly trained gourmet coffee growers would still struggle for forward integration into the more lucrative stages of production, the greatest advantage to be gained is to establish a trade relationship with a purchaser who values the wellbeing of the producer as well as the commercial quality of the product. Though coffee growers' prospects are limited for independently cashing in on the value they can add to their coffee, partnership with sympathetic fair trade purchasers provides coffee growers with the best of both worlds - capacity development to upgrade their skills as producers of quality coffee, information to negotiate for themselves a better coffee price, and security to participate in an "unequal exchange" with more "fair" terms of trade. The fair trade system connects ambitious coffee growers with purchasers whose perceptions of "value" and "quality" necessarily include impact on the lives and communities of their suppliers, because value-capture for quality in the coffee commodity chain is an arena in which coffee growers will never be able to fully compete. 


\section{Chapter VIII: Conclusions}

If there is one commonality to be found among producers and consumers of a good such as coffee, it is the desire for more information about how the international market works. As a result of information sharing and communication technology, both ends of the commodity chain are now more aware than ever of the identity of their trade partners. Consumers' eyes are increasingly opened to contexts of production in less-developed countries, especially the imbalance of intensive labor for meager earnings. To the consumption end, fair trade creates a feeling of being more involved in the lives of coffee growers, less detached from the human act of commodity production, and more influential in the global market by wielding purchasing power in favor of social responsibility. Producers, on the other hand, are discovering novel options for selling their product and aspiring to negotiate more directly with their buyers. The opportunities arising out of the global market are promising of a future where growers assume more control over the export process, recoup costs normally retained in black box fees of shipping and handling, and gain the market advantages of capitalizing on the opportune moments to buy and sell.

As a market system, fair trade has been conceived by these two ends of the commodity chain in similarly disparate terms. Consumers in developed countries tend to define a 'fair' version of trade in terms of offering a sort of post-capitalist refuge for producers and a retreat for those they deem to be disadvantaged in the game of price speculation. In contrast, many producers 
in the developing world have received fair trade as a first opportunity to take an active role in the global economy. New players in the international market, they want to want to try their hand at being effective capitalists and attempt to benefit for themselves from the economic processes they have witnessed to result in wealth for so many coffee, cotton, or chocolate barons. For producers, a 'fair' version of trade may involve leveling the playing field via more direct access to new specialty markets.

Current tensions in the fair trade movement are a direct result of the disparity in these concepts of fairness, as well as the conflicting roles that many producers and consumers envision for commodity growers in the global market. In trying to relieve producers from being "at the mercy of the market," fair trade as practiced by the FLO system has defined the economic problem facing producers in terms of price instability. As a result, they offer a guaranteed price as the solution. However, for producers seeking to benefit from a fairer system of trade, the solution often lies in gaining more control over their situation.

As coffee producers and their allies forge new paths into the international market, research is needed for both these new market players and their supporters to understand the myriad forms of market participation and the benefits and drawbacks of each. Fair trade has been promoted as a solution to the vulnerable and disadvantaged position of coffee growers, allowing greater income security, higher prices to producers, and training in the skills needed for forward-integration into more value-adding stages of 
commodity production. In addition to the economic benefits of fair trade, its proponents emphasize the social impact of investment in community development, including social organization and network expansion.

However, for all the hypothetical discussion of fair trade as a revolutionary market for producers, insufficient case studies have demonstrated the varied experience of certification. In Guatemala, for example, producers have both embraced and rejected Fair Trade certification, some reverting back to their original conventional system, others moving beyond certification to develop stronger, more personal ties than the certification system permits. The aim of this study, then, was to evaluate the experience of Fair Trade certification and reveal some of the features most appreciated or most resented by coffee producers. The purpose of this study is to inform agents of development, economists, anthropologists, sociologists, concerned consumers, and other coffee producers of the varied ways in which fair trade works and could be made to work better.

\section{THEORETICAL FOUNDATION}

The fair trade movement began more broadly conceived as what is called an alternative trade movement. Alternative trade organizations sought to revalue goods like handicrafts and textiles with a higher price that reflected not only the intensive labor of production, but also the social and environmental impacts of production. This creates what researchers like Murdoch, Marsden, and Banks (2000) call a "re-embedded" good, where the 
value of a product not simply determined by what a consumer is willing to pay, but it is rooted in local and regional contexts.

This approach to fair trade represents what researchers have termed "market-breaking" (Jaffee 2007) or "alternative globalization" (Fridell 2007). Fair trade constituted a new protected market for producers in less-developed countries, designed to benefit commodity producers who were ill-prepared to compete in the market and entirely dependent on forces out of their control. In the transition to a mainstream market player, the FLO version of fair trade reflects a shift away from the market-breaking goals of alternative trade to a "market reform" (Jaffee 2007) or "shaped advantage" (Fridell 2007) approach where the market becomes a tool for helping producers earn higher profits and fund their development projects. And this move has generated a conflict at the heart of the fair trade movement. This study looked at the tension created by this pull in two opposite directions and ways in which development schemes balance a need for oversimplifying problems and their solutions in order to broaden their reach with a need to re-embed these schemes in their social context in order to increase their efficacy. Fair trade provides a revelatory example of this delicate balance, as it has progressed from personal interaction between producer and consumer to a third-party certified and moderated exchange to a post-certification personal testimonial of fair production and trade conditions. As a result, this study asked:

- What are the development goals held by certified producers and roasters? 
- How does fair trade certification work as a tool to meet these socioeconomic development goals?

Of all varied objectives of the fair trade movement, this and other studies have consistently found economic change to be the highest priority among producers. However, economic benefits have received insufficient in the existing literature on fair trade impacts, which has focused on improved prices to producer cooperatives rather than net income of producer households. The assumption of many proponents of fair trade, including Oxfam, Catholic Relief Services, FLO and Transfair USA, has long been that a shorter commodity chain allows producers to retain a greater portion of the price of their coffee. According to their logic, more direct trade means fewer firms taking a cut of the coffee price returned to farmers. This study examined the effects of altering the commodity chain for coffee to determine whether a shorter chain is, in fact, associated with higher profits to producers. Consequently, this study compared the structure of commodity chains in three communities and the actual take-home pay of coffee growers in different market systems to evaluate the question:

- What is the relationship between the length of the commodity chain and the profits returned to producers?

Development theorists such as Tania Li (2007) and James Scott (1998) suggest that the exclusion of political-economic characteristics of the context of development results in "contradictory, messy, and refractory" outcomes. In the case of fair trade as a market-based development strategy, critics of the 
mainstream version practiced by FLO argue that the distance it allows between producer and purchaser renders is less effective in achieving its own economic and social development objectives. This study examined the effect of disembedding the design of a development program by comparing cooperatives of different political-economic contexts to investigate the question:

- What impact do context-specific characteristics have on the progress towards the development goals held by producers, roasters, and the certifying agency?

Finally, economists and social scientists such as Parrish, Luzadis, and Bentley (2005), Pirotte, Pleyers, and Poncelet (2006), and Colleen Berndt (2007) have criticized the cooperative organization of fair trade for preventing producers from connecting coffee quality with higher demand and higher profits. In an article titled, "Half a Cheer for Fair Trade," Booth and Whetstone (2007) criticize the system as more harmful than helpful for coffee producers. As one of the most heavily traded primary commodities, one which plays a vital role in the national economy of so many Central and South American and African countries, and one which has witnessed a tremendous revaluing in the form of processed goods, the example of coffee provides insight as to the potential for value-adding and the opportunities for value-capture throughout the production process. To evaluate these claims, this study posed the questions:

- What is the relationship between length of the commodity chain and knowledge of the international market for coffee? 
- What is the relationship between knowledge of the international market for coffee and the profits returned to producers?

\section{THE STUDY AND RESEARCH FINDINGS}

The present study incorporates a mixed-methods approach to assess the impact of fair trade on the role coffee growers play in the international market, connecting the theoretical claims of fair trade and its detractors with the experiences of farmers. Over the course of eighteen months of fieldwork, I conducted interviews and surveys and practiced participant observation to collect data from both coffee producers in Guatemala as well as coffee roasters in the US. The combination of methods conducted in a variety of research sites has allowed me to identify both patterns in fair trade experiences as well as anomalies which can be attributed to site-specific conditions.

In identifying the development goals held by producers and roasters and evaluating the efficacy of fair trade in meeting these goals, this study found that the fair trade experience is fraught with tradeoffs. Though economic benefits occupy the central position in producers' aspirations for fair trade, some roasters selling relationship coffee claim that the FLO certification system is misdirected in that the guaranteed minimum price has only risen once since 1988 despite rising costs of living and production in producer countries. In some cases, the FLO system allows purchasers to make claims of practicing fair trade despite minimal commitment to the purchasing 
cooperative. Contrary to the message often shared by such organizations as FLO and Oxfam, many relationship coffee roasters have little expectation that higher coffee prices can end producer poverty. On the other hand, the roasters recognize that fair trade brings unanticipated benefits in the form of additional development support, such as helping broaden the social networks of cooperatives to connect producers to resources and services they need, generating the data needed to compose funding proposals, and investing directly in human capital development such as education and skills training.

Many coffee growers also expressed disappointment in the economic impacts of Fair Trade. Though fair trade was designed to mitigate the disastrous effects of price fluctuations, interviews revealed that many producers see price changes as a fact of life. In fact, most all producers contacted for this project initially saw fair trade as a means of becoming more competitive in the market and capitalizing on fluctuating prices. They believed that by entering the fair trade system, they were proactively pursuing a market advantage. If they followed certain steps to obtain certification, they could sell coffee in what they refer to as "preferred markets." As the conventional price has risen years to approach the guaranteed minimum offered by FLO, many producers who have continued maintained certification have watched their price advantage diminish. As a result many coffee growers are becoming resentful of Fair Trade, and in interviews I often heard the phrase "Ya no es justo"or, "It's not fair anymore." 
Resentment towards fair trade is especially pertinent among producers in Bella Vista and La Esperanza who were accustomed to conventional growing practices and had to learn new cultivation techniques, which are significantly more labor intensive, in order to receive certification. Moreover, in this study, residents in Bella Vista also had decades of experience negotiating their own coffee prices in the conventional market prior to obtaining FLO certification. For residents in these two communities, then, their political and economic conditions have resulted in the opinion that the hoops they have to jump to participate in the Fair Trade market are not worth the payoff.

In Alta Vista, however, producers are still learning cultivation techniques and marketing, so their challenges and resources differ significantly from the other two cooperatives. With no background in coffee, they have no grounds for comparing their current Fair Trade practices with conventional production and marketing. Because they are just establishing their skills as coffee growers, the guaranteed price is very important to them. Even more important is the social development support they receive through their fair trade partners.

Regarding the relationship between the length of the commodity chain and the profits returned to producers, I used interview and survey data to construct commodity chain diagrams for each cooperative in the three communities. I asked cooperative leaders about contract prices, the destination of coffee beyond the farm gate, and the fees discounted for each stage of processing. Only a few studies have provided findings of actual net 
earnings of coffee producers in Fair Trade production. Among them, Jaffee's 2007 study of South Mexican growers and Utting-Chamorro's work (2005) with Nicaraguan growers found meager financial gains as a result of FLO prices. Moreover, these gains were offset by the debts many producers accrued in order to meet new production requirements. For this reason, I asked producers a series of questions to determine the amount of money they received from the cooperative both initially and after repaying any loans they had taken out to fund coffee production and harvesting. This gave a more accurate representation of the final per-pound profits producers actually receive through their market system.

This study determined the shortest commodity chain - that of Alta Gracia selling "relationship coffee" - did not actually equal the greatest profits to producers. Though the Alta Gracia cooperative received the highest perpound contract price, the smaller harvest and higher overhead costs of producer households consumed any financial gain they stood to collect. In contrast, though the Fair Trade certified cooperative in Bella Vista markets through a slightly longer chain as a result of an umbrella cooperative of producers, this system distributes the costs of processing and export across a larger number of producers. As a result, the Fair Trade certified group actually received the highest per-pound price after deductions of fees and loan repayment.

Interestingly, though, the Fair Trade certified cooperative in Bella Vista expressed the most dissatisfaction with the financial impacts of their market 
system. Those who had opted to return to conventional production described a lack of transparency in the deductions taken by the umbrella producer cooperative. They felt they would be better off handling the price negotiations and process costs on their own. These producers were not much concerned with the difference between their earnings and final retail prices in the US or Europe or Japan. These producers were more focused on keeping the greatest portion of the per-pound price received by the cooperative. While their counterpart conventional cooperative received a lower contract price, fewer deductions for processing and transport meant a greater portion of the contract price reached producer households. For the Fair Trade certified cooperative, the glaring disparity, between the price promised to the cooperative and what members eventually received effectively explains the frustration of these producers with the economic impacts of the FLO system.

The decision to leave the FLO system was obviously a difficult one, or else it would have been unanimous in Bella Vista where cooperative members voted to split into two separate groups. The divergence of opinions is evidence that there are other benefits to the FLO system that might compensate for the economic disappointments. Interviews revealed social development support as the main consolation and a source of unanticipated benefits.

In fact, in investigating the impact of context-specific characteristics on progress towards these development goals, interviews indicated that major differences between projects that have failed and projects that have succeeded are the familiarity of the development organization with the 
political-economic context of the site, the level of attention the organization can grant to the requests of the recipients, and the ongoing support offered beyond the initial establishment of the project. Relative to other common sources of development support, fair trade-associated programs are more embedded in the community, reflecting more of the unique political and economic conditions of the site. As a result, the characteristics demonstrated as common among more successful development projects were also characteristic of the unique type of development support offered by the fair trade system.

Within the communities featured in this study, there were myriad examples of failed projects, such as chicken houses, biodiesel production, and community gardens that were doomed from the start because of poor fit with community resources and goals. But the design and objectives of fair tradeassociated programs are more representative of the needs and desires of development recipients. As a result, these projects tend to be more "successful" and appreciated within producer communities. However, as the mainstreaming efforts of fair trade require a process of disembedding rather than direct involvement in producer communities, the advantages fair trade holds in development program design may be compromised in favor of the needs of multinational retailers.

Finally, in evaluating the relationship between the length of the commodity chain and producer knowledge of coffee quality, this study revealed just how limited is the market knowledge of producers in each 
cooperative as well as the disconnect between quality as conceived by producers and quality as communicated by purchasers. Survey data revealed that the indicators of coffee quality cited by producers were similar across all three cooperatives in that they did not match the terms most frequently used by coffee retailers. However, differences were noted between communities in the rate of response to questions of coffee quality. Producers in Alta Gracia were most confident in discussing coffee quality, which they related primarily in terms of careful control of cultivation and processing. In Bella Vista, on the other hand, coffee quality was most often associated with the natural beauty of their location. Producers in La Esperanza cited yet another definition of quality, focusing more on the organic status in contention at the time of this research. The eagerness of Alta Gracia residents to discuss quality as well as the agency they assume in improving their product suggests that fair trade cannot be justifiably accused of obscuring from producers the information they need to enhance the value of their product.

However, interviews with coffee roasters illuminated the structural obstacles that continue to prevent producers from turning market knowledge into product value. The fees and bureaucracy incurred through direct export exclude producers of the membership size and productive capacity featured in this study from any of the value-adding activities that occur further down the commodity chain. Moreover, when economists hail competitions such as the Cup of Excellence auction as a shining example of turning quality into profits, they overlook the fact that producers of a primary commodity such as coffee 
are forever at the mercy of environmental conditions. As much as they can control the quality of the final product, no amount of market knowledge or processing skills can insure producers against a few days of heavy rain or harsh winds, both of which can easily destroy an annual harvest. Fair trade, then, provides a safety net for producers to learn about concepts of quality and best practices while still supported by a guaranteed minimum price, a longterm buyer, and a social network on stand-by in case of natural disaster. This demonstrates the broader conception of quality called for by members of the fair trade movement, encompassing not only the results of product evaluation but also the characteristics of the trade relationship and its repercussions in the context of production.

\section{CONTRIBUTIONS}

In assessing the impact of fair trade on the role that coffee growers play in the international market, this study connects the theoretical claims of fair trade proponents and detractors with the experiences of farmers. The findings of this study contribute to the advancement of economic anthropology and sociology, development theory, globalization studies, and commodity chain and global value chain analyses.

Because the embedded nature of purchasers/development agents characteristic of fair trade should theoretically resolve a pitfall of oversimplified development problems and solutions, this study tests the specific hypotheses that fair trade-supported development projects are more closely synced with 
producers' goals and more successful in the long-term. Fair trade-supported projects are demonstrated here as more successful in the eyes of recipients in that they are more enduring and relevant to their personal development objectives. Projects that "failed" were characterized by oversight of sitespecific details such as social organization, environmental conditions, supplementary resources, local markets, and general interest in the project. In contrast, more successful programs addressed the needs identified by recipients, investing in existing projects, human capital development, and community infrastructure. However, participation in the mainstream market threatens to compromise this advantage that fair trade organizations hold in realizing the development objectives of coffee producers.

Since fair trade proposes to alter the commodity chain for coffee, this study tests the specific hypotheses that the fair trade market system is comprised of fewer links in the commodity chain and that having fewer links results in greater profits to producers. The commodity chains I constructed in this study indicated that the FLO market system, not the relationship coffee system, ultimately delivered the highest per-pound price. This demonstrates that shortening commodity chain, though it may increase prices to the cooperative, does not guarantee higher prices to producers. Instead, such factors as cooperative size, productive capacity, experience in coffee growing, costs of production, household size, loans, and employment alternatives can all affect the final profits earned by producers. 
This study contributes to development and globalization studies by highlighting the complexity of development goals among coffee producers. The satisfaction of producers with their market system was more complicated than a simple matter of, "Well, do they receive more money or not?" A more insightful question asks "Are they getting what they wanted out this system?" For producers looking for a safe market environment, the answer might be yes. But for those seeking a competitive edge in the market, FLO certification misses the mark.

Moreover, this study furthers development studies in rural livelihoods analysis by demonstrating the ways in which coffee producers engage in market systems to maximize their resources and employ them to new ends. Fair trade impacts are notoriously difficult to assess since benefits do not always appear in the form of financial capital, but can still be a beneficial byproduct of this particular market system. By illuminating some of the ways in which fair trade is used as a tool to develop the capitals and capabilities of producers, the findings in this study contribute to the work on livelihoods analysis outlined first by Bebbington (1999) and applied specifically by UttingChamorro (2005) to the case of Nicaraguan coffee growers.

As a livelihood strategy, fair trade uses the production and sale of coffee as a vehicle for enhancing other capitals. For example, the skills in environmental sustainability developed through training in environmentally responsible production methods allows producers to preserve as well as improve upon one of the hottest commodities in Central American countries - 
land holdings. As landowners, producers have the opportunity to collect vital herbs and greens as well as plant supplementary crops such as lemons and bananas. For many producers in this study, even though coffee cultivation alone is admittedly insufficient to generate any major changes in standards of living, landholdings themselves can be valuable enough to trump a more lucrative career that requires moving to the city.

Moreover, in a fair trade system, producers learn ecological methods of pest control and receive an economic incentive for manually controlling overgrowth, both practices that further mitigate soil erosion - a common cause for concern on such steep hillsides as coffee farms are often located. This not only allows producers to maintain quality landholdings, but also develops natural capital as a lucrative resource that can be used to add value to a coffee product or as a draw to encourage tourists to the community for bird watching and nature hikes.

In another strategy, the fair trade system enhances the social capital of producers by introducing connections to resources outside the community. This is especially important for producers in remote areas, who fall outside the immediate attention of government services. Enhanced social networks provide an important safety net that becomes especially valuable in times of crisis, as when a hurricane damages vital infrastructure or jeopardizes crucial sources of income.

Furthermore, through these social networks producers have received support in human capital development, in the form of scholarships for young 
students, transportation to secondary education, and continuing education for adults. Many roasters in the fair trade movement believe coffee production alone is a dead-end economic strategy while education will open to producers and their children new avenues for household and community development. Treating coffee as one element of a livelihood strategy reveals its potential for enhancing capitals and capabilities. Viewed in this light, coffee production becomes a vehicle for developing the natural, social, and human capital that producers are seeking in order to pursue new and more promising incomeearning ventures.

\section{RECOMMENDATIONS FOR DEVELOPMENT PROGRAMS}

As this study demonstrates, the development experience can be bittersweet for both donating and receiving ends. For those offering development support, the desire to witness a measurable outcome can supersede the investment of time and resources needed for enduring, meaningful results. The culture of development aid can reinforce this evolution, as donors want to contribute to programs that make a quantifiable difference. As the case studies here illustrate, development programs may make appreciable donations in the form of material resources such as livestock or computers, but a lack of continuing support or investment in buttressing resources often leads to disappointment. Ultimately, donors become frustrated to see their contribution of money and resources abandoned or fallen into disrepair, as was the case with the chicken project, 
biodiesel project, computer lab, and other well-intended efforts. Furthermore, recipients become disillusioned by their own failure to pursue ill-conceived projects to a successful end.

The development experiences of the three communities in this study provide a valuable basis for making recommendations both specific to the design of a development interaction, as well as broadly applicable to the conception of development support. In light of the observations made in Chapter 6, these recommendations may serve to improve future development programs, in general, and the practice of fair trade as a development scheme, specifically.

\section{Recommendation \#1}

$\underline{\text { Return attention to the 'smoothed over' features of the recipient population }}$

In an effort to provide a quick resolution to grave situations, development agencies tend to offer blanket programs broadly labeled as providing 'food security' or 'green energy'. Conceived at a macro level, however, and applied regardless of contextual detail, such projects tend to overlook critical features such as microclimates, political dynamics, and social organization that can lead to 'contradictory, messy, and refractory' outcomes. Examples discussed in this study include projects designed to be run cooperatively in a community that is unaccustomed to cooperative labor, projects raising livestock in an area with inadequate pasture, or roasting projects manned exclusively by a single, controversial political figure. Though 
there is also danger in the converse, of becoming too closely incorporated in the social fabric of a recipient community, investors in development would be well-served to focus resources more intensely in fewer well-conceived projects designed with acknowledgement of 'key political-economic processes' and the uniqueness of each setting in mind. The relative success of fair tradeassociated projects in this study, including renovation of coffee plots and organic fertilizer production, demonstrate that more focused development projects can gain in efficacy what they lose in broad applicability.

\section{Recommendation \#2}

\section{Envision development as a longer-term process}

Again, this recommendation requires a reconceptualization of the predominant development enterprise, where one-time donations of materials or money are believed to suffice as provision of aid. Projects offered by visitors to a community - be they development organizations, student groups, or recreational travelers who consider donations to be another vacation expense - can have unanticipated adverse effects on the recipients. Though these projects are introduced with the best of intentions - laying the foundation for food security with a community vegetable garden or facilitating information access with a computer lab - interviewees often expressed exasperation at their continued inability to sustain such projects, particularly after donors' emphasis on the life-altering importance of these projects. Though there is a respectable focus on 'sustainability' of development projects and aversion to 
fostering development dependency, countermeasures frequently err on the side of project abandonment, and producers find themselves at a loss for ongoing consultation or complimentary resources. A prime example of this can be found in the computer lab project, where an admirable donation of computers, startup funds, and a business plan would have been more effective if conceived as an ongoing project, with continued consultation for budgeting and training of staff for programming and repairs. Projects associated with fair trade partners tended to be more successful, as they provided for long-term, complimentary consultation services in fertilizer production, seedling cultivation, and pest management, thereby securing support in the long-term with a more thorough and holistically-conceived plan.

\section{Recommendation \#3}

\section{Consider new indicators for "success"}

Rather than quantifiable donations of money or materials, recipients benefit immensely from investments in human capital. Of the investments in development received by the interviewees in this study, educational opportunities were among the most highly valued. Once again, this may conflict with the culture of development wherein development agents necessarily report to donors measurable outcomes such as dollar amounts invested, supplies purchased, or items donated. But these indicators could be reconceived as skills taught, educational opportunities offered, or incorporation of previously difficult-to-reach populations, such as mothers or teenaged 
children. While such declarations as the number of recipients reached and the dollar amounts invested in a project may convey to donors the quantity of their impact, these indicators do not effectively describe the quality of the impact. The mere presence or absence of a banana bread baking project does little to explain the significance of a project that provides women with a commitment outside the home and the rare opportunity to earn an income for their household, nor the challenge of securing for women the right to participate, nor the prevailing expectation of failure due to machista assumptions within the community. Fair trade-associated projects, on the other hand often focus on the quality of the intervention. In particular, fair trade members that maintain close contact with their communities may define 'success' and 'failure' more broadly, finding achievement in a non-profit project that provides educational or social opportunities, or recognizing shortcomings in a lucrative project that fails to include the most marginal community members.

\section{Recommendation \#4}

$\underline{\text { Return agency to recipients in the "trustee" relationship }}$

Applied to both development in general and fair trade in particular, this recommendation calls for greater producer participation in goal-setting and solution-devising. Interviewees had become so accustomed to their role as beneficiaries rather than partners in development that our discussions frequently concluded with a plea for my 'expert' advice. They often asked that I identify for them what they were doing well, where they had strayed from the 
path to progress, and how to get back on course for development. Instead of evaluating for these communities where their needs and goals lie, both agents of development and the communities they serve would benefit from adopting the philosophy of 'people-centered development', wherein the recipients play a more collaborative role in determining their needs and designing their resolution. In the role of 'trustee', development agents ideally work with recipients to "enhance their capacity for action, and to direct it" (Li 2007:5), which fosters long-term skills in more independently assessing and resolving development needs. Though fair trade-associated projects evidenced greater producer input, and these projects were generally regarded by producers as more successful than those introduced exclusively from outside agents, there is still a need for increased producer participation. The repeated requests that I share their opinions and inform their partners in the Fair Trade network of "what is going on here" indicate the still anemic role of producers in determining the course of their own development.

\section{Recommendation \#5}

Provide certified producers with a guaranteed benefit, not guaranteed price

Dovetailing with the previous recommendation, this recommendation addresses a common complaint of producers, one which has received little audience in the certifying end of Fair Trade. In light of rising coffee prices, many interviewees expressed frustration with Fair Trade and organic certification, with the phrase 'ya no es justo' (it is no longer fair) recurring as a 
common theme, in both interviews and informal conversation. The requirements for maintaining certification have not changed, and the minimum Fair Trade price has only risen once since certification was formalized in 1988 (Equal Exchange N.d.b). In effect, then, fair trade producers continue to work much harder than conventional producers, only now they are receiving nearly the same price for a significantly greater investment of time and labor. While coffee purchasers view the central mission of fair trade as removing producers from the risky business of price speculation, producers believe the purpose of fair trade is to earn a higher price for their coffee by cultivating with best practices. To focus solely on the market-breaking goals without acknowledging producers' market-reform objectives is to exclude the beneficiaries of the program from setting their own goals and objectives. A provision granting producers a minimum price or, in the event that the conventional price rises to meet this minimum price, a minimum differential over the conventional price would ensure that producers receive fair compensation for their greater investment in coffee production.

\section{FRUITFUL AREAS FOR CONTINUED RESEARCH}

In the course of this study, there arose several essential and pressing agendas for research which were reluctantly deemed outside the scope of this project. However, these courses of research would make further contributions to the academic realms of economic anthropology and sociology, development theory, globalization studies, and commodity chain and global value chain 
analyses. Furthermore, pursuit of these areas of research could yield the evidence needed to demonstrate the dire need for a reconceptualization of the development practice.

Building on the findings of this study, an investigation of the characteristics of development projects deemed successful by their recipients could compare projects designed with ongoing involvement of the development agency versus projects comprised of one-time donations. The observations made in this study suggest that, on one hand, there is a need for development agencies' greater involvement in recipient communities while, on the other hand, too much involvement compromises the ability of the agency to work within the community. To better evaluate this threshold of too little or too much embeddedness, a study could elicit from recipients a development history for their community as well as the extent of involvement of the supporting agency, followed by the recipient's assessment of the relative success of each project.

Pursuing a tangential path of inquiry only briefly examined in this study, more research is needed into the experience of coffee growers who participate in quality competitions. While economists, free market enthusiasts, and proponents of the field-leveling effect of informational access in the age of globalization champion the income-earning opportunities of quality competitions, insufficient research has investigated the perspective of participants in these coffee auctions. Little is known of the goals of small producers who enter arenas such as the Cup of Excellence competition. As a 
market strategy, is the competition viewed as an end in itself, a venue in which producers strive to sell greater volumes of higher quality coffee? Or is the competition a gateway to establishing more favorable opportunities outside the competition? Are small producer groups approached to enter the competition or do they seek out these opportunities independently? How does the vision held by producers of the function of coffee auctions compare with the expectations held by the advocates of a clearer supply and demand connection? Much as the present study bridges a gap between hypothetical scenarios and actual practice, these research questions would shed light on the similarities and distances between the theoretical potential for producers to increase their earnings through quality improvement and the experience of producers who have entered such an arena.

Finally, to investigate one of the most surprising findings in this study, continued research could conduct a broader survey of producers with Fair Trade certification to reveal their preference for a fixed price calculated as a dollar amount or a price differential. Contrary to popular belief, the producers in this study were more intent upon acquiring skills to become more competitive in the market than escaping the game of price speculation. While Fair Trade presumes to protect producers from another coffee crisis, interviewees expressed an acceptance of price fluctuations and preferred instead to have more control over their path of entry into the market. A comparative study could survey producers with varying years of experience in coffee production and sale, in varying regions of the coffee growing world, or 
even in varying Fair Trade certified commodities, inquiring as to their expectations for the Fair Trade system. Such a study would reveal the impetus for producers to obtain certification and the role they envision for themselves in the international marketplace. The findings of this study could inform both agents of development as well as development and globalization theorists who wish to better understand the desires and objectives of primary commodity producers as relative newcomers to the globalized market, as well as how to help them achieve their goals.

In considering the fair trade movement and Fair Trade certification as development schemes of discernible impact, this study examines both the conduct of development agencies as well as the content of development programs. Though bittersweet, the fair trade experience presents a learning opportunity for a wide range of audiences, from the certified to the certifiers to the concerned public and the conscientious consumer. This study has framed several lessons learned in terms of 1. the socioeconomic impacts of fair trade, 2. the characteristics associated with positive development encounters, and 3. the potential for commodity producers to capture value further along their global value chain. In presenting these research findings, my hope is to provide concrete case studies that allow theorists to better understand the practical implications of their logical assumptions, provide development programs with insights to better serve recipient populations, and express on behalf of recipients some of their urgent concerns. The importance of bridging this gap between abstraction and realization cannot be overstated, nor can the 
need for connecting emic accounts with etic observations. The limitless nature of contextual details suggests infinite potential for continued research in this vein. As we begin to understand more profoundly the dynamics of commodity production, marketing, consumption, and the conduct and content of development, we can identify more clearly the modern roots of the "new inequality" to design more satisfying programs worthy of all our energy and aspirations. 


\section{LIST OF REFERENCES}

Arce, Alberto

2009 Living in Times of Solidarity: Fair Trade and the Fractured Life Worlds of Guatemalan Coffee Farmers. Journal of International Development 21:1031-1041.

\section{Bacon, Christopher}

2005 Confronting the Coffee Crisis: Can Fair Trade, Organic, and Specialty Coffees Reduce Small-Scale Farmer Vulnerability in Northern Nicaragua?. World Development 33(3):497-511.

Bacon, Christopher M., V. Ernesto Méndez, Stephen R. Gliessman, David Goodman, and Jonathan A. Fox, eds.

2008 Confronting the Coffee Crisis: Fair Trade, Sustainable Livelihoods and Ecosystems in Mexico and Central America. Cambridge: MIT Press.

Barrientos, Stephanie, Michael E. Conroy, and Elaine Jones 2007 Northern Social Movements and Fair Trade. In Fair Trade: the Challenges of Transforming Globalization. Laura T. Raynolds, Douglas L. Murray, and John Wilkinson, eds. New York: Routledge.

Bebbington, Anthony 1999 Capitals and Capabilities: A Framework for Analyzing Peasant Viability, Rural Livelihoods and Poverty. World Development 27(12):2021-2043.

Bernard, H. R.

2006 Research Methods in Anthropology: Qualitative and Quantitative Approaches. $4^{\text {th }}$ edition. Walnut Creek, CA: AltaMira Press.

Berndt, C. E. H

2007 Is Fair Trade in Coffee Production Fair and Useful? Evidence from Costa Rica and Guatemala and Implications for Policy. Mercatus Policy Series, Policy Comment. 11.

Booth, Philip and Linda Whetstone

2007 Half a Cheer for Fair Trade. Economic Affairs 27(2):29-36.

Bray, David Barton, Jose Luis Plaza Sanchez, and Ellen Contreras Murphy 2002 Social Dimensions of Organic Coffee Production in Mexico: Lessons for

Eco-Labeling Initiatives. Society and Natural Resources 15(5):429-446.

Brown, Michael Barratt

2007 'Fair Trade' with Africa. Review of African Political Economy 34(112):267-277. 
Bryceson, Deborah, Cristóbal Kay, and Jos E. Mooij

2000 Disappearing Peasantries? Rural Labor in Africa, Asia and Latin

America. London: Intermediate Technology Publications.

Bunker, Stephen G.

2001 Coffee and the Guatemalan State. In Globalization on the Ground:

Postbellum Guatemalan Democracy and Development. Chase-Dunn,

Christopher K., Susanne Jonas, and Nelson Amaro, eds. Lanham, MD:

Rowman \& Littlefield Publishers.

Calo, Muriel, and Timothy A. Wise

2005 Revaluing Peasant Coffee Production. Medford, MA: Global

Development and Environment Institute, Tufts University.

Cambranes, J.C.

1985 Coffee and Peasants: the Origins of the Modern Plantation Economy in Guatemala, 1853-1897. Vermont: CIRMA.

Cardoso, Fernando Henrique, and Enzo Faletto

1979 Dependency and Development in Latin America. Berkeley: University of California Press.

Castillo, Rosalva Aida Hernandez, and Ronald Nigh

1998 Global Processes and Local Identity Among Mayan Coffee Growers in

Chiapas, Mexico. American Anthropologist 100(1):136-147.

Chenery, Hollis. B.

1961 Comparative Advantage and Development Policy. The American

Economic Review 51(1):18-51.

Coffee Analysts

2008 Frequently Asked Questions. http://www.coffeeanalysts.com/faqs/, accessed August 6, 2008.

Conroy, Michael E.

2007 Branded! How the 'Certification Revolution' is Transforming Global

Corporations. Gabriola Island, BC, Canada: New Society Publishers.

Cup of Excellence

N.d.a 2008 Guatemala Cup of Excellence Auction Results http://www.cupofexcellence.org/CountryPrograms/Guatemala/2008Progra m/AuctionResults/tabid/443/Default.aspx, accessed February 6, 2012.

N.d.b Auction Results: Lot\#: 2 Coex (Guatemala), S. A. - La Bendicion http://www.cupofexcellence.org/CountryPrograms/Guatemala/2008Progra $\mathrm{m} /$ AuctionResults/tabid/443/mid/777/ItemID/995/Default.aspx, accessed February 6, 2012. 
N.d.c Auction Results: Lot\#: 10 Julio Jose Garcia Soto - Chalabal http://www.cupofexcellence.org/CountryPrograms/Guatemala/2008Progra $\mathrm{m} /$ AuctionResults/tabid/443/mid/777//temID/1003/Default.aspx, accessed February 6, 2012.

N.d.d Auction Results: Lot\#: 12 Juan Ramon Flores Salazar - Florencia Y Anexo http://www.cupofexcellence.org/CountryPrograms/Guatemala/2008Progra m/AuctionResults/tabid/443/mid/777//temID/1005/Default.aspx, accessed February 6, 2012.

N.d.e Auction Results: Lot\#: 15 Izabel Reynavillatoro Hernandez - Las Rosas http://www.cupofexcellence.org/CountryPrograms/Guatemala/2008Progra $\mathrm{m} /$ AuctionResults/tabid/443/mid/777//temID/1008/Default.aspx, accessed February 6, 2012.

N.d.f Auction Results: Lot\#: 19 Henio Perez Melendez - La Soledad Y Anexo http://www.cupofexcellence.org/CountryPrograms/Guatemala/2008Progra m/AuctionResults/tabid/443/mid/777/ItemID/1012/Default.aspx, Accessed February 6, 2012.

N.d.g Auction Results: Lot\#: 20 Julian Alquejay, Miguel Chen And Jesus Morales - Chichupac (33.33\% Each Grower) http://www.cupofexcellence.org/CountryPrograms/Guatemala/2008Progra m/AuctionResults/tabid/443/mid/777/ItemlD/1013/Default.aspx, Accessed February 6, 2012.

N.d.h Auction Results: Lot\#: 21 Emilio Ical Lem And Ricardo Jom Lem - La Pacaya (50\%) And La Cumbre Amalem (50\%) http://www.cupofexcellence.org/CountryPrograms/Guatemala/2008Progra m/AuctionResults/tabid/443/mid/777/ltemID/1014/Default.aspx, Accessed February 6, 2012.

Daviron, Benoît, and Stefano Ponte 2005 The Coffee Paradox: Global Markets, Commodity Trade and the Elusive Promise of Development. London: Zed Books.

\section{Dean's Beans}

N.d. What is People-Centered Development? http://www.deansbeans.com/coffee/people_centered.html, accessed February 6, 2012.

2011 So Who Can You Trust? http://www.deansbeans.com/coffee/deans_zine.html?blogid=1028\&utm_so urce=896\&utm_medium=email\&utm_campaign=896, accessed March 31, 2012.

Driscoll, David L., Afua Appiah-Yeboah, Philip Salib, and Douglas J. Rupert 2007 Merging Qualitative and Quantitative Data in Mixed Methods Research: How To and Why Not. Ecological and Environmental Anthropology 3(1):1928. 
Eakin, Hallie, Catherine Tucker, and Edwin Castellanos

2006 Responding to the Coffee Crisis: A Pilot Study of Farmers' Adaptations in Mexico, Guatemala and Honduras. The Geographical Journal 172(2):156-171.

Earley, Matt

2006 The Power of 100!!! Support the Santa Anita Coop

http://www.justcoffee.coop/node/621, accessed February 5, 2012.

2011 Beyond Price: Building a Better Prefinancing Model

http://www.justcoffee.coop/node/12887, accessed February 5, 2012.

Encyclopædia Britannica

N.d. Machismo.

http://www.britannica.com/EBchecked/topic/1381820/machismo, accessed February 12, 2012.

Equal Exchange

N.d.a Our Co-op http://www.equalexchange.coop/our-co-op, accessed March 31, 2012.

N.d.b We're Officially Raising the Prices We Pay to Coffee Farmers http://www.equalexchange.coop/were-officially-raising-the-prices-we-payto-coffee-farmers, accessed February 22, 2012.

Esty, Daniel C. and Andrew S. Winston

2006 Green to Gold: How Smart Companies Use Environmental Strategy to Innovate, Create Value, and Build Competitive Advantage. New Haven, CT: Yale University Press.

Ethiopian Coffee Network

N.d. Company Profile: Planet Bean Coffee

http://www.ethiopiancoffeenetwork.com/profiles/planetbean.shtml, accessed February 5, 2012.

Fairtrade Foundation

N.d.a Fair Trade Proof http://www.coopcoffees.com/what/fair-trade-proof, accessed February 6, 2012.

N.d.b FAQs: What is the Fairtrade Premium? http://www.Fair

Trade.org.uk/what_is_Fair Trade/faqs.aspx, accessed February 5, 2012.

Fairtrade International

N.d. Aims of Fairtrade Standards http://www.Fair Trade.net/aims_of_Fair

Trade_standards.html, accessed February 5, 2012.

Fairtrade Labelling Organizations International (FLO)

2006 About Fair Trade. Electronic document, http://www.Fairtrade.net/about_Fairtrade.html, accessed January 2, 2009. 
2009 Generic Fairtrade Standards for Small Producers' Organizations.

Electronic document, http://www.fas.usda.gov/info/Child_labor/04-

10_EN_Generic_Fairtrade_Standards_SPO_Aug_09_EN_amended_versi on_04-10.pdf, accessed March 31, 2012.

2011a Fairtrade Standard for Small Producer Organizations. Electronic document, http://www.fairtrade.net/fileadmin/user_upload/content/2011-1227_SPO_EN_FINAL.pdf, accessed February 16, 2011.

$201 \overline{1 b}$ What is Fairtrade? http://www.fairtrade.net/what_is_fairtrade.html, accessed February 14, 2012.

Fair Trade Federation

N.d. Fair Trade Myths http://www.Fair

Tradefederation.org/ht/d/sp/i/198/pid/198, accessed February 5, 2012.

Fair Trade USA

N.d. Producer Profiles. http://fairtradeusa.org/certification/get-certified, accessed February 15, 2012.

Ferguson, James

1994 The Anti-Politics Machine: "Development," Depoliticization, and Bureaucratic Power in Lesotho. Cambridge University Press.

Fisher, Carolyn 2007 Patronage and Governance in Nicaraguan Rural "Development"

Projects. Paper presented at the Annual Meeting of the American Anthropological Association, Washington, D.C., November 28.

Fitter, Robert, and Raphael Kaplinsky

2001 Can an Agricultural 'Commodity' Be De-commodified, and if so Who is to Gain? Discussion Paper No. 380. Brighton: Institute of Development Studies.

Frank, Andre Gunder

1969 Capitalism and Underdevelopment in Latin America: Historical Studies of Chile and Brasil. New York: Modern Reader Paperbacks.

Fridell, Gavin

2006 Fairtrade and the International Moral Economy: Within and Against the Market. In Global Citizenship and Environmental Justice. Tony Shallcross and John Robinson, eds. Amsterdam: Rodopi.

2007 Fair Trade Coffee: The Prospects and Pitfalls of Market-Driven Social Justice. Toronto: University of Toronto Press. 
Gereffi, Gary, and Miguel Korzeniewicz

1994 Commodity Chains and Global Capitalism. Westport, CN: Greenwood Press.

Gibbon, Peter, Jennifer Bair, and Stefano Ponte

2008 Governing Global Value Chains: An Introduction. Economy and Society 37(3):315-338.

Golding, Kirsty, and Ken Peattie

2005 In Search of a Golden Blend: Perspectives on the Marketing of Fair

Trade Coffee. Theme issue, "Special Issue: Fair Trade, Business and

Sustainable Development," Sustainable Development 13(3):154.

Gresser, Charis, and Sophia Tickell

2002 Mugged: Poverty in your Coffee Cup. Oxford: Oxfam International.

Grimes, Kimberly

2000 Democratizing International Production and Trade: North American

Alternative Trading Organizations. In Artisans and Cooperatives:

Developing Alternate Trade for the Global Economy. Kimberly M. Grimes

and B. Lynne Milgram, eds. Pp. 11-24. Tucson: University of Arizona

Press.

Hudson, Mark, and lan Hudson

2004 Justice, Sustainability, and the Fair Trade Movement: A Case Study of Coffee Production in Chiapas. Social Justice 31(3):130-146.

International Coffee Organization (ICO)

N.d. All Exporting Countries: Prices Paid to Growers (in Current Terms).

Electronic document http://www.ico.org/historical/2000+/PDF/PricestoGrowers.pdf, accessed February 15, 2012.

Jaffee, Daniel

2007 Brewing Justice: Fair Trade Coffee, Sustainability, and Survival.

Berkeley: University of California Press.

Just Coffee

2009 Specialty Coffee Association of America Green Coffee FOB, C \& F, CIF Contract. Electronic document, http://www.justcoffee.coop/files/GUS101.pdf, accessed February 5, 2012.

N.d.a Just Coffees Mission http://www.justcoffee.coop/just_coffees_mission, accessed February 5, 2012.

N.d.b Supply Chain Map 1.0 http://www.justcoffee.coop/map/supplychain, accessed February 6, 2012. 
Latour, Bruno

1987 Science in Action: How to Follow Scientists and Engineers through

Society. Cambridge, MA: Harvard University Press.

LeClair, Mark S.

2002 Fighting the Tide: Alternative Trade Organizations in the Era of Global

Free Trade. World Development 30(6):949-958.

Levi, Margaret, and April Linton

2003 Fair Trade: A Cup at a Time?. Politics \& Society 31(3):407-432.

$\mathrm{Li}$, Tania

2005 Beyond "The State" and Failed Schemes. Theme issue, "In Focus:

Moral Economies, State Spaces, and Categorical Violence:

Anthropological Engagements with the Work of James Scott," American Anthropologist 107(3):383-394.

2007 The Will to Improve: Governmentality, Development, and the Practice of Politics. Durham, NC: Duke University Press.

Linton, April

2005 Partnering for Sustainability: Business-NGO Alliances in the Coffee Industry. Development in Practice 15(3-4):600-614.

Luetchford, Peter

2007 Fair Trade and a Global Commodity: Coffee in Costa Rica. London:

Pluto Press.

Lyon, Sarah

2006 Evaluating Fair Trade Consumption: Politics, Defetishization and Producer Participation. International Journal of Consumer Studies 30(5):401-525.

2007 Maya Coffee Farmers and Fair Trade: Assessing the Benefits and

Limitations of Alternative Markets. Culture \& Agriculture 29(2):100-112.

Macdonald, Kate

2007 Globalising Justice within Coffee Supply Chains? Fair Trade, Starbucks and the Transformation of Supply Chain Governance. Third World Quarterly 28(4):793-812.

Macy's European Coffeehouse \& Bakery

N.d. Macy's Coffee http://macyscoffee.com/html/coffee.htm, accessed February 5, 2012.

Mauss, Marcel

1990[1950] The Gift: The Form and Reason for Exchange in Archaic

Societies. New York: W. W. Norton \& Company, Inc. 
Milford, Anna

2004 Coffee, Co-operatives and Competition: The Impact of Fair Trade.

Electronic document,

http://www.fairtrade.net/uploads/media/Milford_Coffee.pdf, accessed April 13, 2008.

Murdoch, Jonathan, Terry Marsden, and Jo Banks

2000 Quality, Nature, and Embeddedness: Some Theoretical Considerations in the Context of the Food Sector. Economic Geography 76(2):107-125.

Murray, Douglas L., Laura T. Raynolds, and Peter L. Taylor 2006 The Future of Fair Trade Coffee: Dilemmas Facing Latin America's Small-Scale Producers, Development in Practice 16(2):179-192.

Mutersbaugh, Tad

2005 Just-in-Space: Certified Rural Projects, Labor of Quality, and Regulatory Spaces. Journal of Rural Studies 21(4):389-401.

Nash, June

1979 We Eat the Mines and the Mines Eat Us. New York: Columbia University Press.

Neilsen, Lisa A.

2010 Boycott or Buycott? Understanding Political Consumerism. Journal of Consumer Behavior 9(3):214-227.

Ogden, Laura

2008 Searching for Paradise in the Florida Everglades. Cultural Geographies 15(2):207-229.

Oxfam

N.d. Wake Up, Smell the Injustice. Oxfam GB. http://www.oxfam.org.uk/get_involved/campaign/impact/starbucks.html, accessed February 14, 2012.

Parrish, Bradley D., Valerie A. Luzadis, and William R. Bentley 2005 What Tanzania's Coffee Farmers Can Teach the World: A Performance-Based Look at the Fair Trade-Free Trade Debate. Theme issue, "Special Issue: Fair Trade, Business and Sustainable Development," Sustainable Development 13(3):177-189.

Pendergrast, Mark 2000 Uncommon Grounds: The History of Coffee and How It Transformed Our World. New York: Basic Books. 
Pirotte, Gautier, Geoffrey Pleyers, and Marc Poncelet 2006 Fair-trade Coffee in Nicaragua and Tanzania: A Comparison.

Development in Practice 16(5):441-451.

Ponte, Stefano

2002 The 'Latte Revolution'? Regulation, Markets, and Consumption in the Global Coffee Chain. World Development 30(7):1099-1122.

Quaffee

N.d. Coffee Flavours Tasting Wheel http://www.quaffee.co.za/Pages/xtras/CoffeeCupping.aspx, accessed February 5, 2012.

Raynolds, Laura

2002 Poverty Alleviation through Participation in Fair Trade Coffee Networks: Existing Research and Critical Issues. Background Paper, New York: The Ford Foundation.

2009 Mainstreaming Fair Trade Coffee: From Partnership to Traceability. World Development 37(6):1083-1093.

Raynolds, Laura T., Douglas Murray, and Peter Leigh Taylor 2004 Fair Trade Coffee: Building Producer Capacity via Global Networks. Journal of International Development 16(8):1109-1121.

Renard, Marie-Christine

1999 The Interstices of Globalization: The Example of Fair Coffee. Sociologia Ruralis 39(4):484.

2005 Quality Certification, Regulation and Power in Fair Trade. Theme issue,

"Certifying Rural Spaces: Quality-Certified Products and Rural

Governance," Journal of Rural Studies 21(4):419.

Rice, Robert

2003 Coffee Production in a Time of Crisis. SAIS Review 23(1):221-245.

Robbins, Peter

2003 Stolen Fruit: The Tropical Commodities Disaster. London: Zed Books.

Ronchi, Loraine

2002 The Impact of Fair Trade on Producers and their Organizations: A Case

Study with COOCAFE in Costa Rica. Falmer, Brighton, UK: Poverty

Research Unit at Sussex.

Rosenbaum, Brenda, and Liliana Goldín 1997 New Exchange Processes in the International Market: The Re-Making of Maya Artisan Production in Guatemala. Museum Anthropology 21(2):7282. 
Rosenthal, Elisabeth

2011 Heat Damages Colombia Coffee, Raising Prices. New York Times, March 9. Electronic document, http://www.nytimes.com/2011/03/10/science/earth/10coffee.html?pagewant ed=all, accessed February 15, 2012.

Samper Kutschbach, Mario 2003 In Difficult Times: Colombian and Costa Rican Coffee Growers from Prosperity to Crisis, 1920-1936. In Coffee, Society, and Power in Latin America. William Roseberry, Lowell Gudmundson, and Mario Samper Kutschbach, eds. Baltimore: The Johns Hopkins Press.

Scott, James C.

1998 Seeing Like a State: How Certain Schemes to Improve the Human Condition Have Failed. New Haven, CT: Yale University Press.

Shannon, Seth W.

2009 Economic Stimulation: The History and Hope of Coffee in Development. Transnational Law \& Contemporary Problems 18(1):170-196.

Sick, Deborah

1999 Farmers of the Golden Bean: Costa Rican Households and the Global Coffee Economy. Dekalb, IL: Northern Illinois University Press.

So, Alvin Y.

1990 Social Change and Development: Modernization, Dependency, and World-System Theories. Newbury Park, CA: Sage Publications.

Sustainable Harvest

N.d. Relationship Coffees http://www.sustainableharvest.com/relationshipcoffee/, accessed February 5, 2012.

Talbot, John M.

1995 The Regulation of the World Coffee Market: Tropical Commodities and the Limits of Globalization. In Agrarian Orders in the World Economy. Philip McMichael, ed. Westport: Praeger Publishers.

2002 Tropical Commodity Chains, Forward Integration Strategies and International Inequality: Coffee, Cocoa and Tea. Review of International Political Economy 9(4):701.

2004 Grounds for Agreement: The Political Economy of the Coffee

Commodity Chain. Lanham, MD: Rowman and Littlefield Publishers.

Tallontire, Anne

2000 Partnerships in Fair Trade: Reflections from a Case Study of Café Direct. Development in Practice 10(2):166-177 
Taylor, Peter Leigh

2003 Poverty Alleviation through Participation in Fair Trade Coffee Networks:

Synthesis of Case Study Research Question Findings. Report prepared for

One Cup at a Time: Poverty Alleviation and Fair Trade Coffee in Latin

America. D. Murray, L.T. Raynolds, \& P. L. Taylor, Eds. New York: The

Ford Foundation.

2005 In the Market but Not of It: Fair Trade Coffee and Forest Stewardship

Council Certification as Market-Based Social Change. World Development 33(1): 129-147.

Topik, Steven

2003 The Integration of the World Coffee Market. In The Global Coffee Economy in Africa, Asia, and Latin America, 1500-1989. William Gervase Clarence-Smith and Steven Topik, eds. Pp. 21-49. Cambridge: Cambridge University Press.

Transport Information Services

N.d. Flowchart illustrating the wet process http://www.tisgdv.de/tis_e/ware/genuss/kaffee/kaffee.htm, accessed 5, 2012.

Utting-Chamorro, Karla 2005 Does Fair Trade Make a Difference? The Case of Small Coffee Producers in Nicaragua. Development in Practice 15(3-4):584-599.

Watanabe, John Mamoru 1992 Maya Saints and Souls in a Changing World. Austin: University of Texas Press.

Williams, Robert G. 1994 States and Social Evolution: Coffee and the Rise of National Governments in Central America. Chapel Hill: The University of North Carolina Press.

Wingens, Jean Nicolas, ed. 2009 Coffee: Growing, Processing, Sustainable Production. $2^{\text {nd }}$ edition. Weinheim, Germany: WILEY-VCH Verlag GmbH \& Co. KgaA. 


\section{APPENDIX}

\section{Coffee Survey}

\section{Demographics}

Genero

Cuántos años tiene usted?

Usted es casado/a?

Tiene hijos?

Cuántos hijos tiene?

Cuántos años tienen ellos?

Cuántas personas en total viven en su casa?

Asistía usted la escuela?

Cuál nivel logró?

Hace cuántos años vive usted en esta comunidad?

Hace cuántos años trabaja usted en el café?

\section{Terreno}

Cuántas cuerdas en total tiene usted sembradas en café?

Siembra usted otras cosas a parte del café? sí no Cuáles cosas siembra?

Cuántas cuerdas de terreno tiene usted? 
Cuánto tiempo le lleva a llegar a su parcela mas lejana?
Allí siembra café?
síno

Cuánto tiempo le lleva a llegar a su parcela mas cercana?
Ahí siembra café?
sí no

Cuántos años tienen las matas de café mas viejas de su terreno?

Cuántos años tienen las matas de café mas jovenes de su terreno?

\section{Trabajo}

Tiene usted otro trabajo a parte de cultivar café?

Que hace?

Cuántas días por semana ... o por mes... trabaja en esto?

Cuántas personas de su familia trabajan con usted en el cultivo de café?

Quíenes son las personas de su familia que trabajan en su cafetal? Y Que trabajos hacen? 
Tiene que pagar a otros para ayudarle en el cultivo de café? sí no Cuánto dinero gasta usted en un año en jornaleros?

Siempre emplea a las mismas personas?

Emplea usted a hombres y mujeres? sí no

Cuánto paga a un hombre?

Cuánto paga a un mujer?

Ha asistido alguna vez a una capacitacion sobre el cultivo de café?

sí no

Cuantas veces?

Cuál tipo? (gira? afuera?)

Quíen se la dio? O de que institucíon?

\section{Inversion}

Sembró usted matas nuevas del café en el año pasado?

$\begin{array}{lll}\text { Podría decirme cuántas matas? } & & \text { Y de cuál variedad? } \\ \text { Bourbon } & \text { Catimor } \\ \text { Catuai } & & \text { Caturra } \\ \text { Maragogype } & & \\ \text { Pache Colis } & \text { Pacamara } \\ \text { Robusta } & & \\ \text { Typica } & & \text { Pache } \\ \end{array}$

Cuánto dinero en total gastó usted en la compra de matas de café?

Echó usted algun químico en el cultivo de café el año pasado? sí no 
Echó usted algun tipo de abono en el año pasado?

sí no

Cuánto abono aplicó en el cultivo de café el año pasado?

Cuánto dinero gastó en abono en el año pasado?

\section{Producción}

Cuántos quintales de café en uva cortó usted del su terreno en el año pasado?

Entregó su café a la cooperativa/a el grupo organico/a el grupo convencional el año pasado?

Cuántos quintales entregó a la cooperative/al grupo?

Cuánto dinero recibió por este café?

Vendió su café en otro lugar además de la cooperativa/grupo?

sí no

En dónde vendió este café?

Cuántos quintales vendió en otro lugar?

Cuánto dinero recibió por este café?

Cuánto dinero recibió en total por la venta de café en el año pasado? 


\section{Comparasiones}

Cortó mas en este año o en el año anterior?

Recibió un precio mas alto en este año o en el año anterior?

Piensa que va a cortar mas este año que en el año pasado? sí no

Piensa que va a recibir un precio mejor que el del año pasado?

sí no

Qué prefiere usted: un precio variable o un precio fijo?

Qué prefiere usted: $\underline{\text { mejorar la calidad de su café o mejorar la cantidad }}$ de su cosecha?

\section{Cadena}

Sabe a dónde va el café despues de salir de la comunidad?

sí no

Y despues?

$Y$ despues?

$Y$ despues?

$Y$ despues?

Sabe en dónde se vende su café? sí no

Sabe cuánto vale su café en bolsa cuando se vende al consumidor final? 


\section{VIII.Assessment of knowledge}

\section{A. Quality descriptors:}

Como se describe un café de alta/buena calidad?

Como se describe un café de menos calidad?

De qué altura es el café que se produce acá?

$\begin{array}{lll}\text { Estrictamente Duro } & \text { Duro } & \text { Pemi Duro } \\ \text { Extra Primo } & & \text { Primo }\end{array}$

\section{B. Coffee varietal identification:}

Cuáles son las variedades de café que se siembran en Guatemala?

Bourbon

Catuai

Maragogype

Pache Colis

Robusta

Typica
Catimor

Caturra

Pacamara

Pache

San Ramon 
Cuáles son las variedades que valen mas?

(liste del mas caro a mas barato)

\begin{tabular}{|c|c|}
\hline Bourbon & Catimor \\
\hline Catuai & Caturra \\
\hline Maragogype & Pacamara \\
\hline Pache Colis & Pache \\
\hline Robusta & San Ramon \\
\hline
\end{tabular}

Typica

\section{Coffee price information:}

En dónde puede conseguir información sobre los precios actuales de café?

\section{Quality improvement practices}

Manejo de sombra y tejido

1. Hace usted algo para el manejo de tejido? sí no

Qué hace?

poda baja o recepa
poda alta o descope
despunte herbáceo
poda Guatemala o agobio
deshijes

Plagas y enfermedades del café

2. Cuáles son las plagas que mas afectan su cafetal?

Cuál es la principal plaga en su región? 
Cuál es la plaga mas importante en Guatemala?

Hace algo para controlar las plagas en su cafetal?

sí no

Qué hace?

Muestro (suelo o hoja)
Control biologico
Manejo de sombra
Manejo de tejido
Control de malezas
Control manual
Control etológico (uso de trampas)
Control químico

Conservación de suelos

3. Hace algo para evitar la pérdida de suelo por erosión? sí no Qué hace?

$\begin{array}{ll}- & \text { Acequias de ladera } \\ & \text { Terrazas } \\ & \text { Barreras vivas } \\ & \text { Control de malezas } \\ & \text { Siembra en contorno }\end{array}$


Manejo integrado de malezas y equipos de aspersion

4. Hace algo para el manejo de las malezas? sí no

Qué hace?

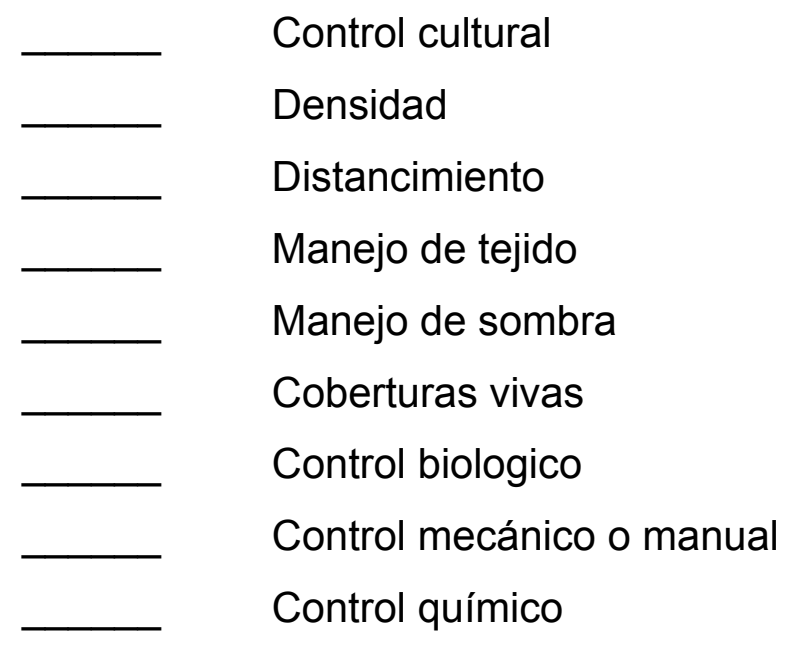

Semilleros y almacigos

5. Tiene su propio almacigo de café? sí no

Por que no?

\section{Posición economica}

Cuánto dinero necesita una familia como la suya para vivir en un mes?

Ganan ustedes suficiente para cobrar esta cantidad?

sí no

Ganan mas que eso... eso... menos que eso?

Les falta/les sobra mucho o poco? 
VITA

COURTNEY MARIE DOWDALL

December 10, 1979

1998-2002

1999-2002

2002-2003

2003-2006

2008

2008-2012
Born. St. Louis, Missouri

B.A., Sociology and Anthropology

Truman State University

Kirksville, Missouri

Teaching Assistant to Dr. Ding-Hwa Hsieh

Truman State University

Kirksville, Missouri

English Teacher

Bell Cram School

Taichung, Taiwan

Program Coordinator - Supported Employment MERS/Goodwill

St. Louis, Missouri

M.A. Comparative Sociology

Florida International University

Miami, Florida

Doctoral Candidate

Florida International University

\section{PUBLICATIONS AND PRESENTATIONS}

Dowdall, Courtney, (March 31, 2001). Cultural Materialist Analysis of Fasting Practices in Orthodox Russia. Paper presented at the $78^{\text {th }}$ Annual Meeting of the Central States Anthropological Society, Lexington, Kentucky.

Dowdall, Courtney, (March 9, 2002). The Influence of Structural Elements on the Formation of Russian Feminism. Paper presented at the $79^{\text {th }}$ Annual Meeting of the Central States Anthropological Society, East Lansing, Michigan.

Dowdall, Courtney, (March 23, 2002). The Woman Question. Paper presented at the $2^{\text {nd }}$ Annual Third-Wave Feminism Conference at Truman State University, Kirksville, Missouri. 
Dowdall, Courtney, and Ryan Klotz, (February 15, 2008). Topic

Reformulations and the Process of Fieldwork in Guatemala. Colloquium presentation for the Florida International University Department of Sociology and Anthropology, Miami, Florida.

Dowdall, Courtney, (March 18, 2009). FairTrade in Guatemala: Experiences and Insights of Producer Cooperatives. Presented at the Lindenwood University Speaker Series, St. Charles, Missouri.

Dowdall, Courtney, (March 21, 2009). Altering the Commodity Chain: Coffee Growers' Experiences with FairTrade Certification. Paper presented at the $69^{\text {th }}$ Annual Meeting of the Society for Applied Anthropology, Santa Fe, New Mexico.

Dowdall, Courtney, and Ryan Klotz, (2009). Feeding Our Land, Feeding Our Family. Book chapter accepted December 2009 for publication in Environmental Health Narratives: A Reader for Youth.

Dowdall, Courtney, (March 25, 2010). Coffee Tourism and Women's Perceptions of Changing Socioeconomic Roles in Western Highlands, Guatemala. Paper presented at the $70^{\text {th }}$ Annual Meeting of the Society for Applied Anthropology, Mérida, Mexico.

Dowdall, Courtney, and Ryan Klotz, (September 19, 2011). Community Level Variation and the Shifting Role of the Researcher in Guatemalan Campesino Communities. Presented at the Truman State University Folklore Colloquium, Kirksville, Missouri.

Dowdall, Courtney, (November 16, 2011). Freedom or Fairness? A Coffee Cooperative Searches for the Better Deal. Paper presented at the $110^{\text {th }}$ Annual Meeting of the American Anthropological Association, Montréal, Quebec, Canada.

Goldín, Liliana, and Courtney Dowdall, (2010). The Rule of the Law and the Enforcement of the Law: Workers' Understanding of Labor Rights in Export Processing of the Central Highlands of Guatemala. Journal article accepted June 2010 for publication in Latin American Perspectives. 